\title{
THE FORGOTTEN WAR
}

\section{AUSTRALIAN INVOLVEMENT IN THE SOUTH AFRICAN CONFLICT OF 1899-1902}

\section{L.M. FIELD}

This thesis is presented for the Degree of Master of Arts

in the Australian National University

September 1973 


\section{TABLE OF CONTENTS}

Page

ABBREVIATIONS

ii.

INTRODUCTION

CHAPTER I Australian Commitment to the

CHAPTER II Preparations for War

CHAPTER III

The First and Second Contingents in the Field

CHAPTER IV The Bushmen, The Draft Contingents, and the Australian Commonwealth Horse

CHAPTER V Opinions of the Australian Soldier

APPENDIX A

Report on the Commandants' Conference

APPENDIX B

Colonial Office Despatch of 3 October 1899

264

APPENDIX C

Details of Colonial Contingents

APPENDIX D

Selected Casualties

272

APPENDIX E

Australian Decorations

273

BIBLIOGRAPHY

274

MAP OF THEATRE OF WAR 


\section{ABBREVIATIONS}

A.N.L. Australian National Library

A.W.M. Australian War Memorial Library.

M.L. Mitchell Library.

M.I. Mounted Infantry.

M.R. Mounted Rifles. 


\section{INTRODUCTION}

This thesis is an attempt to write a critical history of Australia's part in the South African War. There is no existing work of that nature. The "official" account edited by P.L. Murray" is invaluable for statistics, but otherwise it is a collection of brief reports from unit leaders on the war service of their commands. Several other books have a greater narrative quality but they confine themselves to the work of particular regiments, and all suffer from the fact that their authors were part of the eruption of imperialist sentiment that characterised the time. None attempts a survey. of the home front.

Difficulties encountered have resulted from the paucity of source material, and the fragmentation of the Australian contingents, which makes it difficult to follow their progress during the earlier phases of the war, and impossible to do so in the later, guerrilla phases of the conflict. It is hoped, however, that the thesis gives a coherent account of Australia's first war, from the first steps towards commitment to the work of the last soldiers in the field.

1 Official Records of the Australian Military Contingents to the War in South Africa, (Melbourne, 1911). 


\section{CHAPTER I}

\section{Australian Commitment to The \\ SOUTH African WAR}

In late October 1899, the Australian colonies were in tumult as enthusiastic crowds farewelled the volunteers of the first contingent to the South African War. Never before in their history had the colonies acted with such an appearance of unity; it augured well for the nationhood to which, with the exception of Western Australia, they were committed by referenda. But it was something of a paradox that the unanimity displayed in Australia's involvement in the war rested substantially on a keen rivalry, demonstrated over the previous months as the colonies vied with each other in their offers of military assistance and protestations of loyalty.

Few would have guessed at the great reserves of emotional loyalty to Empire which were revealed among colonists who, for two decades, had been cultivating a nationalism that seemed to draw its sustenance chiefly from opposition to Imperial authority and a mild contempt for Englishmen. Imperial Federation had failed because it presumed a dedication to the imperial idea which apparently did not exist; but the response of the colonies in 1899 was so enthusiastic that supporters could again court the idea of a federation of the Empire. The "new-chum". Englishman, for so long the measure against which native Australians calculated their own superior worth, now suddenty lost some of the stigma attached to him and there arose "this strange, new enthusiasm, this unusual regard for the English, this singular acceptance of the new-chum as a man and a brother". ${ }^{1}$

1 J.H.M. Abbott, Plain and Veldt (London, 1903), p. 24. 
Fear of becoming embroiled in Britain's wars had been evident in the colonial debates on the ratification of the 1887 Naval Agreement, as well as in the opposition to the Imperial Federation movement. Yet the colonies, with little evidence of apprehension, now committed themselves to a war of unknown merit in which the deployment and control of Australian troops were handed over entirely, even gladly, to British authority.

Another reversal of opinion was seen in the popular attitude to things military, which moved from antipathy to apparent ardour. The intimidatory role in which militia units had been cast by governments during the great strikes of the early nineties had attracted to the defence forces a certain odium. The episodes were now conveniently forgotten. Even Colone1 Tom Price, who had earned the contempt of unionists by an alleged instruction to his troops, when confronting strikers, to "Fire low and lay 'em out", was hailed by the fickle masses when he marched through Melbourne at the head of the second Victorian contingent.

What had happened to bring about this change of Australian attitudes? A feeling of insecurity was undoubtedly one factor. Japan, Germany, France and Russia were all abroad in the Pacific. The tendency of the last years of the century was clearly towards co-operation with Britain as Australians realised the weakness of their defences. One of the reasons for involvement put forward by supporters of the New South Wales military expedition to the Soudan in 1885 was the need to ensure Imperial military assistance when required by going to Britain's aid when she was at war. The same argument was used widely in 1899 by parliament and press to justify the South African adventure. Evident in the Soudan commitment was a brash nationalism which demanded that Australia stand beside Britain "no longer a mere dependency" but "her compeer and ally". ${ }^{2}$ This, too, became a rallying cry

2 Frank Hutchinson and Francis Myers, The Australian Contingent,. (Sydney, 1885), p. 3. 
as the Transvaal crisis deepened. Then there was the widely expressed moral obligation to stand by the motherland when she was in trouble. This was not surprising since the same sentiment held firm fifteen and even forty years later despite the national growing-up process.

These factors were basic to the entry of the Australian colonies into their first real war; but that entry was made inevitable by a series of events extending from May 1899 to October of the same year. Involved in the drift to war were the defence forces, the executives of the colonial legislatures, the Colonial Office, the press, the legislatures themselves, and finally the people. The movement towards the ultimate dispatch of troops proceeded sometimes almost imperceptibly, but at all times inexorably until most colonial legislatures were called upon merely to give parliamentary sanction to prior executive and military activity.

The initiative to send an Australian contingent came from the defence forces; and they did much to keep alive the idea of going to war during the months when other Australians were less enthusiastic. In 1899 they showed just the same desire for a foreign adventure as they had shown in 1885, when a contingent of 770 men from New South Wales went to the Soudan, and volunteers pressed forward in South Australia, Victoria and Queensland. New South Wales troopers had also been keen to fight for the Empire in the Afridi campaign of 1897 , but the premier, G.H. Reid, had not felt disposed on that occasion to transmit their offer to the Imperial authorities as he thought such an expedition might promote "a spirit of unrest and military adventure" in the colony. ${ }^{3}$ As the Empire faced no significant threat either in the Soudan or on the North-West frontier, the colonial offers could be

3 Frank Wilkinson, Australian Cavalry, (Sydney, 1901), p. 18. The offer was from the O.C., N.S.W. Lancers, but other units were interested. 
safely interpreted as rising in part from the desire of men, in a society generally sceptical of military worth, to justify their existence as soldiers and increase their efficiency by engaging in some form of warfare.

The same desire could also be seen in the visits to Great Britain of Australian military units for the purpose of training with regular troops. As early as 1893 a detachment of New South Wales Lancers went to Britain at their own expense to compete in the Islington and Dublin tournaments. ${ }^{4}$ Such enthusiasm was significant, but equally significant was the success of the detachment. The colonials were able to hold their own with British regular regiments of proud tradition in the common events of military tournaments: lemon-cutting, tent-pegging, tilting at the ring and sword exercises. The visit was probably the first important contribution to the building up of self-esteem among Australian militia units.

The feeling would have been enhanced in 1897 when a11 colonies but Tasmania sent contingents to the Diamond Jubilee celebrations in London, an occasion when Englishmen thrilled to the military potential of the loyal colonies; and the colonies in turn were flattered and elevated by the motherland's praise for the physique and bearing of their keen but untried troops who, in addition to marching impressively (and very proudly) in that greatest of all displays of Imperial pomp and might, "again distinguished themselves in the tournament ring". ${ }^{5}$ As in 1893 , the troops had met a11 or the greater part of their expenses themselves. ${ }^{6}$

The keenness of regiments to gain experience with British regulars was further indicated in early 1899 when a detachment of 102 New South Wales Lancers visited England for cavalry training at Aldershot. The Home govern-

$4 \quad$ ibid, p. 13.

5 ibid, p. 16.

6 Wilkinson, Australian Cavalry, p. 16; Hutton Papers, A.N.L., Australian Newspapers, Vol. 6, p. 27, Daily Mail, 22 April 1897. 
ment supplied horses, lodging and rations for the men but other expenses were met by the members of the detachment, the regiment and friends of the regiment. The New South Wales government made no contribution although Reid had supported the idea of troop exchange at the 1897 Colonial Conference. The premier declined to give financial assistance on the grounds that if the Lancers received government support other branches of the service could also demand it. ${ }^{7}$

The praise of a man like Major-General E.T.H. Hutton would have been a factor in heightening the morale of the Australian militiaman to the point where he hankered after war. Hutton, New South Wales military commandant from 1893 to 1896 and a world authority on the role and training of mounted infantry, proclaimed Australians as "the finest type on the face of the earth for mounted riflemen". ${ }^{8}$ In a lecture to the Aldershot Military Society, he said of the men of his recent command:

No man...be he a Cromwell or a Napoleon, could drive the Australian troops, but a strong and capable leader, no matter how strict, could lead an Australian army to emulate - aye, and surpass if needs be - the finest and most heroic deeds recorded in the annals of the British army.?

Even allowing for the bias of a man who had been responsible for the development of a significant portion of the troops he was now praising, Hutton's estimate, made as it was before an eminent military body, indicated that Australia's infant military forces had established as favourable an identity as was possible without battle experience.

The need for such experience to preserve the morale of the defence forces became evident as the early months of 1899 rolled by. The colonial

7 N.S.W.P.D., 1899, First Series, Vol. XCVII, Leg. Ass., p. 411.

8 Hutton Papers, Australian Newspapers, Vo1. 6, p. 42, Sydney Morning Herald, 10 July 1893.

9 Hutton Papers, English Newspapers, Vol. 9, p. 29. From an editorial in the Howke's Bay Herald, 20 February 1897. 
legions were almost full, the forces of the six colonies totalling 18,864 men. The figure included a small permanent cadre of artillerymen in most of the colonies, but was principally made up of partially-paid militia. In New South Wales and Victoria, which together had 70 percent of the total Australian force, the military strength was 92 percent of establishment in each case; the discrepancy being more the result of government economy than lack of enthusiasm for the military life. In Queensland the mounted infantry strength was 96 percent of establishment, although the figure for infantry was only 74 percent, suggesting the appeal of the more glamorous mounted force and the prejudices of the bushmen who mainly constituted it.

Attendance at the annual camps held early in 1899 also indicated a keenness that could not continue to be assuaged by the stereotyped exercises of an Easter encampment. In New South Wales 96 percent of the mounted infantry were in camp for the full period, and the infantry had a record almost as good. In Queensland the daily average attendance of all permanent and militia units for the eight-day camp in May was 88 percent. In Victoria militia attendance was also good but an interesting variation was the figure for the attendance of the Victorian Mounted Rifles. Only 44 percent of all ranks reported to camp. ${ }^{10}$ The explanation does not lie simply in the fact that the V.M.R. was a volunteer corps and as such received very little encouragement from the government in the way of equipment and allowances, because other volunteer corps such as the Australian Horse in New South Wales had excellent attendance records. All was obviously not well with the force that Colonel Tom Price had founded and commanded over the years. A lack of esprit de corps and poor physical standards became evident when military authorities had to go beyond the 800 members of the V.M.R. and

\footnotetext{
10 All figures on strength and attendances are derived from current reports of military commandants to colonial parliaments, and from the Western Australian Year Book for 1900. The reports are available in the appropriate collections of parliamentary papers and, more conveniently, in the library of the Australian War Memorial, where they are collected by colony in single volumes covering several years.
} 
recruit from infantry units to form a mounted force of 125 for the first Victorian contingent.

New South Wales emerges from the commandants' reports of 1899 as possessing clearly the most efficient military organisation in Australia. There existed units of all arms of the service, and as recently as 1898 a volunteer cavalry force of over 500, the Australian Horse, had been recruited with ease. The corps had been raised by Lieut.-Colonel K. Mackay of the New South Wales Legislative Council and so great had been the response of bushmen, to whom the call for volunteers was specifically directed, that Mackay submitted a scheme to Earl Beauchamp, the New South Wales governor, for raising "one or more" regiments of Australian cavalry, to be subsidized by the Imperial government and used for "the defence of the Empire when and where required". He was confident of raising 5,000 men on an Australia-wide basis. ${ }^{11}$

From the healthy colonial military situation described above, it is "easy to understand why the existing defence forces became a pressure group aiming at going to war against the Boers. ${ }^{12}$ Also of great influence in provoking peace-time soldiers to look to the possibility of more war-like pursuits was a section of public opinion which regarded them as "featherbedders" and "swashbucklers", terms meant to convey contempt for the easy life and vanity of the man in uniform. Radical papers such as the Bulletin, the Brisbane Worker, and the Catholic Press held the military man up to ridicule until public opinion quietened them when the war entered a more serious phase. Even the conservative press found little to praise in the soldier until war commenced and he underwent a metamorphosis to become one

11 Correspondence of N.S.W. Governor with Colonial office, C.0. 201/625, Microfilm, A.N.L. Mackay's letter to Beauchamp/French, 18 July 1899. The Colonial Defence Committee put the idea aside until completion of federation and the end of the war in South Africa.

12 The role of the military commandants will be discussed as the story of commitment unfolds. Of particular influence were the three Imperial major-generals commanding in the eastern colonies. 
of "our brave boys". Perhaps most people did see the defence forces as one rough poet saw them:

0 they came from Parramatta, an' they came from Invere11, And they galloped round the Show Ground an' played up like puffick 'ell, Flashin' swords an' 'olding' on their 'ats, all fierce for war's red sport,

While snickerin' town galoots looked on an' cried "What bloomin' sort?"...

Lemon slicin', lemon squashes, decent intervals for booze, That's the proper sort o' warfare to fit in with modern views... ${ }^{13}$

or as Paterson's Driver Smith saw himself:

A-charging the Randwick Rifle Range and aiming at Surry Hills. ${ }^{14}$

With no Australian military tradition to lean on and with little justification for their existence in terms of manifest threats to Australian security, the defence forces were extremely liable to a sceptical evaluation of their worth. Little wonder then that they saw in the worsening Transvaal situation an opportunity to improve their status.

Before the military began to show its hand, however, the civilian sector was given an opportunity to respond to a call to interest itself in the troubles of the Uitlander population of the Transvaal. Early in May the Imperial South African Association in London, a body numbering among its members 80 men of the Imperial parliament, made a request through the press of the principal cities of Australia for moral support for the Uitlanders in their differences with the Transvaal government. ${ }^{15}$ In Sydney on 11 May a meeting was convened by the lord mayor and attended by an estimated 250 people who expressed their sympathy for the Uitlanders. A similar meeting was held in Melbourne Town Ha11 on 16 May, attended by "a large and evident1y

13 Hutton Papers, Australian Newspapers, Vo1. 6, p. 80, Daily TeZegraph, 17 October 1893.

14 A.B. Paterson, Rio Grande and Other Verses, (Sydney, 1933), p. 145.

15 Age, 12 May 1899, p. 5. 
sympathetic audience" which supported the Uitlanders' petition to the Queen for redress of grievances. The Melbourne meeting is interesting because it exemplified the nature of the leadership of the civil sector just prior to and during the war. In addition to the mayoral presence, Sir Henry Wrixon, M.L.C., was there to move the motion of sympathy, and the president of the Chamber of Commerce was there to second it. Support was forthcoming from other parliamentarians and the Rev. Dr. Bevan, precursor of the ubiquitous Protestant (usually Anglican) clergyman who was to appear on similar public platforms with never-flagging Imperial zeal in the months ahead.

The meeting also introduced that note of intolerance which was soon to reveal itself throughout the Australian community. When a member of the audience rose to protest against the chairman's rejection of an amendment and to question anti-Boer attitudes, his voice was drowned in disorder; and when another member who had been in the Transvaal for two years interjected to acknowledge fair treatment at the hands of the Boers, he was advised to "take some sauerkraut" and to go back to South Africa. ${ }^{16}$ Other resolutions supporting the Uitlander cause came from a meeting of an estimated 50 people in Adelaide, ${ }^{17}$ and from a meeting in Bendigo of an undisclosed number. ${ }^{18}$

Regarded absolutely, the Uitlander meetings did not demonstrate very much concern on the part of Australians for British subjects in the Transvaal. But even the concern shown in the meetings described loses most of its significance when the response on behalf of the Uitlanders is compared with the concern shòn by Australians a few months later for a remote Frenchman called Dreyfus. In Melbourne 500 citizens petitioned the mayor to hold a meeting to express indignation at the court's verdict. The meeting drew "an

\footnotetext{
16 ibid, 17 May 1899 , p. 5.

17 ibid, 23 May 1899, p. 5.

18 ibid, 6 June 1899, p. 5.
} 
unusual attendance of ladies and gentlemen". The dour Trades Hall Council passed unanimously a similar motion, and at this time Geelong citizens were petitioning their civic leaders to convene a protest meeting. ${ }^{19}$ At Bendigo Dr. Quick chaired a meeting deploring the verdict at which parliamentarians and clergy spoke; and in Perth "over 2,000" attended a similar meeting in the Town Ha11. 20

The Secretary of State for the Colonies, seeking support for his hardening attitude towards the Transval, was understandably disappointed. He had hoped to include the details of the meetings in a Blue Book, but he noted that only 200 had attended one of the Australian meetings and concluded that, in any case, the resolutions would not have any more effect than those of "a Temperance meeting or Women's Suffrage Association in this country". 21 It was not until the hysterical farewells to the first contingent in October that the public discovered its deep concern for oppressed brothers in the Transvaal.

In the weeks following the Uitlander meetings two other factors in commitment were to reveal themselves; one was military and the other parliamentary, but with a notable exception the parliamentary executives were also found lacking in enthusiasm for the Uitlander cause, leaving the military alone to nurture the idea of foreign adventure.

In June 1899 the London cables (sustaining force of the Australian press, which had no correspondents in South Africa) revealed the gravity of the Transvaal situation. "The Boer Crisis - British War Preparations - Arms Issued to Burghers", cried the $A g e^{22}$ in a typical headline. Leading articles

19 ibid, 16 September 1899, p. 9.

20 ibid, 19 September 1899, p. 5.

21 Correspondence of Victorian Governor with Colonial office, C.0. 309/148, Microfilm, A.N.L. Notation on a cable from Lord Brassey, 19 May 1899, reporting Melbourne meeting re Uitlanders.

2222 June 1899, p. 5. 
on the possibility of war had begun to appear in May and continued through June and July. They showed a healthy diversity of opinion which was to disappear by the end of the year when freedom of speech virtually died in Australia.

The Age had declared itself on the morning prior to the Uitlander sympathy meeting in Melbourne. Its leading article revealed a racial pride and a racial arrogance which were to become the burden of much of what was said on the crisis in press and parliament in the ensuing months. The issue was so simple that the Age could put it in a "nutshe11". The trouble was that "a tyrannous little minority, holding the powers of Government, taxes and impoverishes the majority while denying them the rights of citizens", but unfortunately for peace the British Uitlanders came of a people "which has not been schooled to quietly adopt the role of an inferior race". With a frankness concomitant with arrogance, the paper admitted the existence of Boer grievances, including the fact that "Great Britain wants the Transvaal, as she wants most of South Africa", but felt that if the Boers "had the right to take the land from the natives in the interests of a semi-barbarous settlement, Great Britain has the same right to supersede the Boers in the interests of a higher civilization". ${ }^{23}$

The Brisbane Courier was quick to decry the "haughty tone" of Boer statements, including Commandant Viljoen's belief that God and the Mauser rifle would see the Transvaal through; ${ }^{24}$ and cables such $\wedge^{25}$ the one quoting Chamberlain's view that the Boer claim to independence was nothing but "the right to oppress and exploit the Outlanders" 125 became the ready source of opinion for Australians who were predisposed to such interpretations.

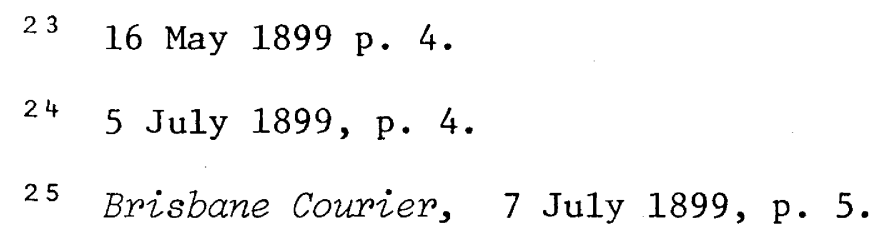


The Sydney Daily Telcograph saw things more fairly. It regarded Uitlander agitation as having forced Chamberlain's hand, and it implied that the Uitlanders were making very heavy demands on the Transvaal government. It was also honest enough to admit that British prestige was really the item at stake. ${ }^{26}$ After President Kruger's concession of the seven-year residential franchise in mid-July, the Argus counselled Uitlander restraint as the Boer was a vanishing quantity. In one sense he was an aboriginal, to be put up with because he was disappearing. ${ }^{27}$ The Bulletin sympathised with the Boers in their fight for a land they had plucked from the wilderness but saw little hope for them. They would be doomed if they reformed their electoral system and doomed if they did not, as British arms would be used to back up the grasping Uitlanders. ${ }^{28}$

The first mention of activity among the military forces came on 26 June, when the Daily Telegraph reported that men of the partially-paid infantry were keen to volunteer for possible Transvaal service. Infantry commanders had for some weeks been contemplating sending a battalion to England for training with Imperial troops at the expense of the regiments concerned. Now with the Transvaal crisis deepening, many of the volunteers for Imperial training suggested that the New South Wales government should offer their services to the War office as a detachment for the Transvaal. "Other branches of the forces were equally eager and ready to go anywhere, provided there was a chance of active service". ${ }^{29}$ Major-General G.A. French, New South Wales military commandant, sanctioned the move (perhaps he initiated it), observing in his usual pontifical manner that a Transvaal contingent was "a more sensible project than Soudan". ${ }^{30}$ On the same day the Daily Telegraph

\begin{tabular}{ll}
\hline 26 & 5 July 1899, p. 6 \\
27 & 22 July 1899, p. 8. \\
28 & 15 July 1899, p. 6. \\
29 & p. 5 \\
30 & p. 5.
\end{tabular}


printed a London cable noting a Canadian "offer" of 2,000 picked men for service in the Trnasvaal in the event of war. ${ }^{31}$

French's activity did not cease with his widely publicised comment favouring a Transvaal contingent. His actions in the day and weeks following certainly marked him as a man who saw the South African situation as the "opportunity of a lifetime". ${ }^{2}$ The Catholic Press was soon to regard him as the man responsible for involving New South Wales in the war. ${ }^{33}$ Reports of volunteering among New South Wales units during the first two weeks of July suggest the hand of French, because it is unlikely that commanding officers would have called for volunteers without the direction of the commandant. On 8 July it was reported that the officer commanding the Newtown Company of the Australian Rifles had sought volunteers for possible service in South Africa. ${ }^{34}$ From Bathurst came a report that 25 men of the Mounted Rifles had volunteered for service in the event of war in response to a "circular", 35 and in Albury 5 members of the Volunteer Corps answered a "call to arms" from "Headquarters". ${ }^{36}$ As early as $14 \mathrm{July}$ French was claiming $1,200-1,500$ volunteers from the defence force. ${ }^{37}$

Before he could use the enthusiasm of his legions to influence the government, however, the parliamentary executives of New South Wales and 31 p. 5 .

32 N.S.W. V. \& P. of Leg. Ass., 1900, Vo1. 4, p. 874. Aillabour member of the Parliamentary Select Committee on the Administration of the Military Department claimed that French had used these words.

3330 September 1899 , p. 15. "...jingoism is the breath of his nostrils, and every officer naturally desires to end up his career amidst military glory".

34 Daily Telegraph, p. 9. More than half the company of 100 were reported to have volunteered.

35 ibid, 11 July 1899, p. 5.

36 ibid, 17 July 1899, p. 5.

37 ibid, 14 July 1899 , p. 5. 
Victoria were asked by Chamberlain himself to pledge unequivocal support for Imperial policy in the Transvaal. The Secretary of State for the Colonies would have welcomed the moral comfort of large colonial meetings demonstrating in support of the Uitlanders but these, as we have seen, had been disappointing. Facing considerable opposition at home and bitter opposition on the continent over his Transvaal policy, Chamberlain sought a clear declaration of support from certain larger colonies. ${ }^{38}$ In a telegram of $3 \mathrm{July}$ he inquired "whether contingents of the New South Wales Lancers and the Victorian Mounted Rifles would offer to accompany British troops in the event of a military demonstration against the Transvaal". ${ }^{39}$

The Colonial office was deeply disappointed at the guarded responses of the governments of the two major Australian colonies. Beauchamp's cable of $5 \mathrm{July}$ was little more than an acknowledgement because Reid was absent from the seat of government, but his assurance that he had sent a special messenger to Reid "urging prompt action" indicated that in his person the Imperial government had an active agent. ${ }^{40}$ The Victorian premier's reply, forwarded through the governor, Lord Brassey, (as was all correspondence with the Imperial government) was evasive: "Troops already desirous of volunteering. Would the Imperial Government repay cost of preliminary

38 The preface to the reply to Chamberlain's telegram from the N.S.W. Governor indicates that Canada was approached as we11 as N.S.W. and Victoria. See C.0. 201/625. Telegram of 9 July 1899.

39 The actual cable is not included in the relevant Colonial office correspondence in the A.N.L. The above is a reported version appended by the Colonial Office to the reply of 5 July 1899 of the Governor of N.S.W. See C.0. 201/625, Microfilm, A.N.L.

Chamberlain's approach was kept a close secret, no mention of it appearing in the press. Reid made a passing reference to it in the October debate, but he did not elaborate and the matter remained secret. No secondary accounts of the war indicate a knowledge of the request.

40 Two months later, Chamberlain recognised Beauchamp's efforts in a note: "I had already realized before I received your letter that you had done all that was possible to persuade Mr. Reid". But Mr. Reid was not to be persuaded. Letters to Lord Beauchamp, 1899-1901; from J. Chamberlain, 31 August 1899, p. 53. Collection A 3012, M.L. 
training?"41 A further cable from Sir George Turner a week later was a similar evasion of decision and an indication that money was to be the root of all loyalty. It read: "Volunteers offer to serve in South Africa, before the Government takes further action, they desire assurance that Imperial Exchequer bear all expenditure. Could you inform me as to rate of pay...". ${ }^{4}$ A New South Wales cable was in similar vein, perhaps because the two premiers had been in consultation. ${ }^{43}$ Reid promised every facility for voluntary enlistment if volunteers were requested but "equipment of troops must involve deficit of revenue, unwilling to incur new taxation or 1oan". 44 But this was not what Chamberlain had wanted. On 11 July the Colonial office replied: "We do not propose to call for volunteers, but a spontaneous offer of co-operation would be welcomed for reasons previously given". 45 Three days later Beauchamp telegraphed: "Premier answers Cabinet do not consider Transval affairs constitute crisis justifying spontaneous offer of a detachment of troops... At the same time Cabinet believe large number of men would willingly enlist for Transvaal service should the Imperial Government desire it...". ${ }^{46}$

This communication showed clearly the situation in New South Wales: vigorous military activity directed towards participation in a possible Transvaal war, and an executive not prepared to commit itself on what would appear to the world to be its own initiative. Expense would have been a big factor in producing executive reluctance; Reid's appraisal of the Transvaal

\footnotetext{
4 Victorian Governor's Correspondence with Colonial office, C.0. 309/148, Microfilm, A.N.L., telegram from Brassey, 5 July 1899.

42 ibid, telegram from Brassey, 12 July 1899.

43 C.0. 309/148, noted in telegram from Brassey, 5 July 1899.

44 C.0. 201/625, Beauchamp to Colonial Office, 9 July 1899.

45 C.0. 201/625, telegram to Beauchamp.

46 C.0. 201/625, Beauchamp to Colonial office, $14 \mathrm{July,} 1899$.
} 
situation might have been another, for the premier was not an illiberal man; and a third factor could have been the attitude of the Labour group whose support kept Reid's ministry in office.

The Colonial office was clearly disappointed at the results of its request for "spontaneous" offers of support. "They do not rise to the occasion", noted Sir Edward Wingfield. ${ }^{4}$ A minute from the Colonial office to the War Office was more caustic. After pointing out that it had been expected that Victoria would volunteer part of its militia force, which would not need the preliminary training mentioned in the Victorian cable of 5 July, the writer suggested "that Sir G. Turner would like to get the cost of the annual training as the price of his loyal offer... It is a pity that the troops who are anxious to volunteer could not inspire some of their spirit into their Premier". ${ }^{48}$

The events of the first weeks of July indicated that the governments of the two premier Australian colonies had no intention of even making a show of rushing into a military adventure. But ministerial coolness in those colonies was not matched in Queensland, and from the north came the first clear commitment to the Imperial cause in South Africa. The motives behind the offer of Queensland troops were possibly more opportunist than loyalist, but contemporary historians were ready to credit Queensland with having set an example for other colonies to follow. ${ }^{49}$ The offer of troops

47 C.0. 201/625. Notation on a Colonial Office memo. of $15 \mathrm{July} 1899$ which, incidenta1ly, indicated that there was no thought at all of utilizing Australian volunteers. Wingfield was the Permanent Under-Secretary.

48 C.0. 309/148, minute from Colonial office to War Office, 14 July 1899.

49 L.S. Amery (ed.), The Times History of the War in South Africa, 6 vols. and index, (London, 1900-09), Vol. II, p. 306; Arthur Conan Doyle, The Great Boer War, (london, 1903), p. 62; William Harding, War in South Africa, (Melbourne, n.d.), p. 565: "...the offer of Queensland was like a spark to gunpowder and the patriotism of all Australia was at once aflame"; Louis Creswicke, South Africa and the Transvaal War, 6 vols, (Edinburgh, 1900-01), Vo1. 3. p. 152: "...the honour of being the first of Great Britain's children to come forward to her assistance...our warlike brothers across the ocean...speedily [Dickson's] action was imitated all over the world". 
in the event of war in South Africa was the first gesture by a government in any part of the Empire. It was the only definite offer by an Australian government before the debates of October. Why should Queensland have taken the initiative? And even more pertinent, who in Queensland took the initiative? Only days after the first reports of military volunteering in the mother colony and in Canada, there came a move in Queensland, of military origin, to send soldiers to South Africa in the event of war. On 6 July Major-General Howel Gunter, military commandant, wrote to the premier, J.R. Dickson, recommending the services of 250 Queensland Mounted Infantry and a machine-gun section in the event of hostilities in the Transvaal. ${ }^{50}$ Gunter's letter did not indicate that he was speaking for a number of volunteers, and it is very doubtful whether his approach to the government actually rose out of an upsurge of enthusiasm among Queensland Mounted Infantry rank and file. During the October debates an opposition member challenged Dickson to give an "atom of proof" that a single volunteer had come forward by 10 July, the day the cable was forwarded to the Colonial office by the governor of Queensland. ${ }^{1}$ In fact, criticism of the source of the offer was common throughout the course of the debate and the government made no attempt to reply to it. Thomas Glassey of the Labour opposition was probably near to the truth when he claimed that a few troopers may have expressed a desire for war service but that the move was really initiated by the military authorities who, he alleged, saw a way of justifying their existence. ${ }^{52}$

When Gunter made his recommendation, parliament was in recess, but the commandant found a willing sponsor in the premier. Dickson had only recently assumed leadership of the government, his election being something

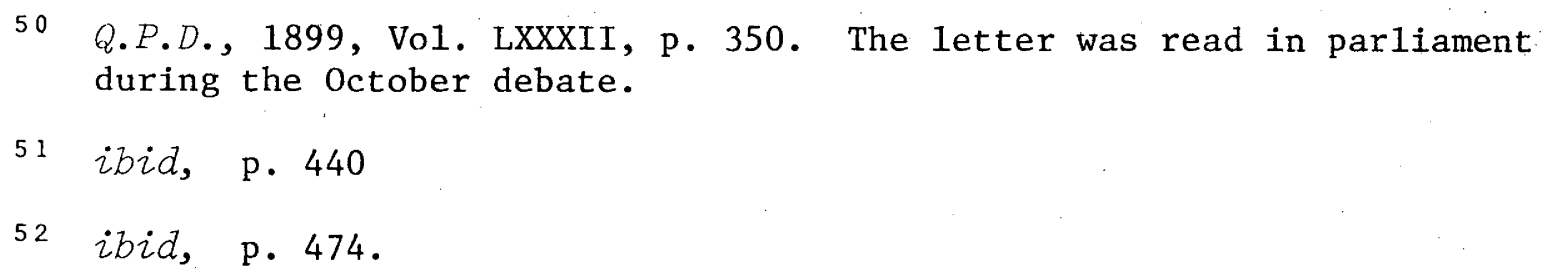


of a surprise. The favourite, Philp, had stood down in Dickson's favour. Coming into the chief executive office as a second choice may have influenced Dickson to look for an opportunity to strengthen his position within the Ministerialist party. The manner in which he later openly revelled in Queensland's distinction at being first to offer troops suggests that he would not have been unmindful in July of the personal honour that might accrue to him in taking the initiative in offering troops.

During the October debate a section of the Labour party constantly accused Dickson of title-hunting, but Dickson claimed as his motive for acting without parliamentary sanction a fear that the chance to help the mother country may have been lost because "the emergency might have passed away". 53 The Queensland parliament had risen on 20 June for an adjournment lasting until 2 September. Twenty days after the adjournment Dickson made his offer. In that period of time had come the New South Wales military activity, the report of a Canadian "offer" of troops, and Gunter's approach, but no sudden and marked deterioration in the Transvaal situation. It is very likely that Dickson had moved precipitately in anticipation of other colonial offers.

Whatever his motives, on 10 July Dickson cabled the Colonial office: "Should hostilities against Transvaal break out Queensland offers services 250 mounted infantry with machine guns". The Colonial office replied on 11 July: "H.M. Government highly appreciate loyal and patriotic offer of Queensland. They hope that the occasion will not arise but if it should arise they will gladly avail themselves of the offer". ${ }^{4}$ From the Queensland government had come, unsolicited, the offer that Chamberlain had sought in vain from New South Wales and Victoria. The Colonial office, possessing some insight into the forces behind Australian politics, optimistically waited for Dickson's action to affect the attitudes of more thoughtful.

\footnotetext{
53 ibid, p. 341.

54 Correspondence of Queensland Governor with Colonial Office, C.0. 234/68, Microfilm, A.N.L.
} 
colonia1 cabinets. 55

The Queensland offer undoubtedly had an effect on the already agitated defence forces of New South Wales, and they in turn were to influence the reluctant Reid with their clamouring for action on troop offers. Not that the New South Wales premier was prompted to take the tentative action that he did purely by the prodding of the military, for Dickson's move had brought into play the most effective political agent of the period inter-colonial rivalry. Reid was now compelled to change his position, but he was able to do so without committing the government in any definite way. The New South Wales parliament, incidenta11y, was in session at the time. Two days after the Queensland offer (along with the approbation of Chamberlain and The Times) had been reported in the Australian press, Major-General French went into print with a blatant1y political statement concerning New South Wales involvement. In an interview widely publicised throughout the eastern colonies (at least), French advocated a selfsustaining federal force of all arms in the event of war in the Transvaal. He was optimistic about the value of Australian troops as part of an Imperial force, seeing them as possessing, among other un-named advantages, a physique superior to British regulars. The cause, he offered, was a good one. The merits of an Australian expedition lay in the fact that "a large number of Australians" were employed in the Transvaal mines and the dispatch of an Australian force "would relieve them of the white tyranny exercised over them". In addition, sending Australian troops would have a favourable moral effect throughout the Empire and would serve to enlighten the world of the unity of Empire. If war did eventuate against the Transvaal there would be no better chance of battle experience because the Boer was a formidable foe. French noted that Canadians had already volunteered and he

55 C.0. 201/625. "Wait and see whether the action of Queensland will change their attitude". - Wingfield's notation on a telegram from Beauchamp, 12 July 1899. 
acclaimed the patriotism of the Queensland offer. Great enthusiasm prevailed, he said, among the New South Wales forces and such enthusiasm would become more manifest with a government offer of troops. ${ }^{56}$ The ball had been thrown to Reid.

It could fairly be assumed that Reid took it up rather reluctantly. On the very day of the publication of French's interview, $14 \mathrm{July}$, Beauchamp had cabled the cabinet's refusal to make a spontaneous offer of troops. But now, only one week later, the governor informed the Colonial office:

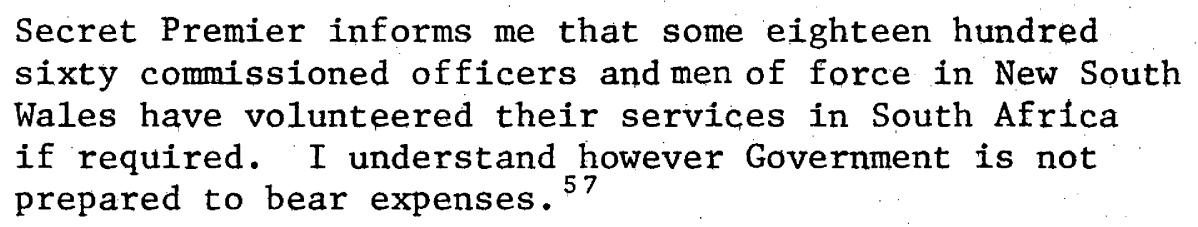

The offer did not directly involve the government but it could be easily inferred that cabinet had given its sanction to an offer from the defence forces under its control. The official channels through which the offer was passed would also have helped in gaining for the communication something of the status of a government decision. In the October debate Reid expressed his confidence that he had not involved the government in any way. Chamberlain, it seems, was no less pleased than if Reid had directly committed the colony. To him the voluntary move by the troops demonstrated the patriotic spirit prevailing in the colony just as well as an offer of troaps by the Government.${ }^{58}$ Perhaps it was only coincidental, but in a speech to the Commons toward the end of July Chamberlain showed a greater determination to protect British subjects and reassert British suzerainty in the Transvaal. In that speech, amid great cheering, the Secretary of State for the Colonies

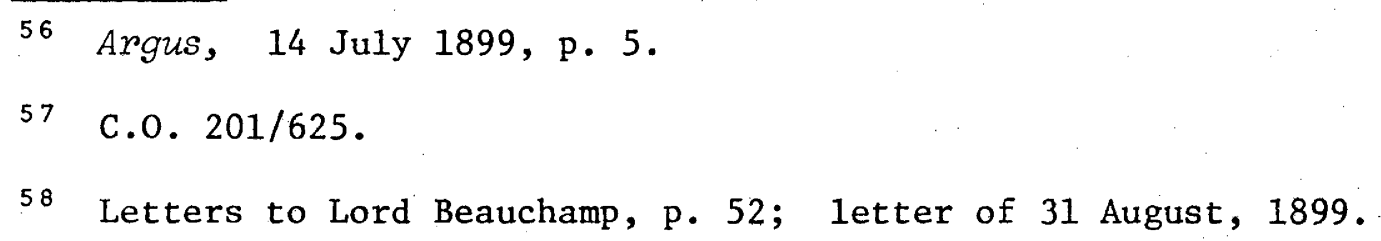


"thankfully recognised" the "offers" of Canada and Australia. ${ }^{59}$ Perhaps French and Dickson caused the South African war!

Reid again indicated his distaste for any show of exuberance over the political and military possibilities of the Transvaal situation, when on $26 \mathrm{July}$ he was once more beset by an external request for a demonstration of Australian support for the British residents of the Transvaal. On this occasion the call came from the Uitlander Council who, in a cable from Natal to Reid (for transmission to the other colonial premiers) sought colonial support for an Uitlander petition to the Queen requesting "relief from oppression and misgovernment". ${ }^{60}$ The inter-governmental action which followed is well documented, for in addition to official sources there exists a summary of the events of August by Attorney-General Bernhard Wise. During the October debate Wise offered a history of Reid's action and inaction as a retort to a claim by the ex-premier that William Lyne had lost the leadership of the Australian colonies to Victoria in the short time he had been in office. ${ }^{61}$

Reid had certainly not moved with any show of urgency, for the contents of the Uitlander telegram were not passed on to the other premiers until 1 August. The replies were an object lesson on the need for a central government. Queensland would join in any representations of sympathy for the Uitlanders provided they were prudent enough not to embarrass Chamberlain, but Dickson felt that his colony had "already given proof of practical sympathy by her offer of troops". Western Australia considered that all that

59 Argus, 31 July 1899 , p. 5.

60 From a volume of N.S.W. Government papers in the A.W.M. Library entitled N.S.W. Soudan and South Africa Contingents 1885-1907, (hereafter N.S.W. Government Papers, A.W.M.), p. 38. The cable was sent on $25 \mathrm{July}$ and received in Sydney the following day.

61 N.S.W.P.D., 1899, First Series, Vo1. C, pp. 1394-5. The Lyne ministry assumed office on 14 September. 
could be done was to express confidence in "the wisdom and justice of the action being taken by the Imperial Government". From Victoria Sir George Turner replied that he had already cabled the Colonial office that popular opinion in Victoria favoured the Uitlanders and that Colonial forces were offering their services. ${ }^{62}$ South Australia and Tasmania both appealed to New South Wales for a lead, but despite the pleas of Kingston, Reid would not be moved. He ignored the initial request from Kingston and a reminder a week later; he rebuffed Kingston's proposal to free voluntarily the Australian Auxiliary Squadron for service outside its home waters just when the South Australian premier appeared to have the concurrence of the other colonies; and he continued to ignore further urgings from Kingston for leadership in some alternative show of moral support for the Home government. In despair at Reid's silence, Kingston enlisted the aid of Lord Tennyson, the South Australian governor, who addressed Reid through Lord Beauchamp, but to no avail. ${ }^{63}$ It would be fair to attribute Reid's' reluctance to a considered view of the Transvaal situation, as revealed in a terse memorandum on the interchange of telegrams:

Put by for the present. I have come to the opinion that the sympathy of the Australian Colonies with the legitimate desires of the British inhabitants of the Transvaal has already been made sufficiently manifest. A difficulty between the British people and the people of the Transvaal scarcely calls for displays of patriotism at this end of the world, the strength of the position being all on the side of Great Britain. 64

62 N.S.W. Government Papers, A.W.M., p. 38. It is intriguing to note that Reid's telegram to Turner and Turner's cable to the Colonial office were both dispatched on 1 August. The practice of "one-up-manship" was so prevalent among colonial premiers at the time that one cannot easily dismiss the suspicion that Turner may not have been completely truthful. in his reply to Reid.

63 N.S.W.P.D., 1899, First Series, Vo1. C, p. 1395; from Wise's account.

64 N.S.W. Government Papers, A.W.M., p. 38. No date shown. 
Kingston had to content himself with a local declaration of Imperial loyalty, but when it came to executive action on the part of his own ministry the message that went forth on 4 September was far more noncommittal than that of the New South Wales government on $21 \mathrm{July}$. The communication to the Colonial Office stated that "from communications made to them" Ministers "have reason to believe that in the event of any circumstances rendering such action desirable some members of the Defence Forces of South Australia would be found willing to volunteer for service beyond the colony". Undefined though the offer was, the Home government replied that they would gladly accept it if necessary. ${ }^{65}$

As September advanced, the outlook in South Africa became bleaker. During the previous months there had been periods of optimism, although they must have created some confusion in the minds of Australians, interspersed as they were among gloomier prognostications. London cables, upon which the public relied for information, were not full and factual accounts that anyone disposed towards critical evaluation might ponder upon. Invariably they were brief statements of journalistic or political opinion based on very inconclusive negotiations between the contending governments. Small wonder that many members of the colonial legislatures later complained bitterly (or admitted blithely) that they were voting on commitment to a war whose immediate origins they knew little of.

Editorial comment in the Australian press acknowledged the worsening position in the Transval. Alleged Boer intransigence brought exasperated outbursts, typical of which was an Argus judgement that long-suffering Britain was being forced to strike as she had spared "an ignorant obstinate and grasping people" as long as she possibly could. ${ }^{66}$ In fact, by September

\footnotetext{
65 S.A.P.D., 1899, p. 595.

664 September 1899 , p. 4.
} 
both Briton and Boer were poised to strike. Paul Kruger could no longer contemplate a franchise extension which would spell the eventual end of the South African Republic and now the old patriarch waited for the spring rains to blanket the veldt with crisp forage for the sturdy ponies of his commandos. International arbitration was the only alternative to conflict as far as Kruger was concerned, and Britain, asserting her position as suzerain power in the Transvaal, would not accept this. The issue was as clear to the Home government as it was to Kruger, and it went far beyond questionable Uitlander grievances: British hegemony was threatened in South Africa and with it her prestige throughout the world.

On 12 September, an ultimatum from Chamberlain was read to the Volksraad demanding a five year residential franchise, more goldfields members in the legislature, parity of English with Dutch in parliament and law courts, a conference to settle franchise details, and guarantees of concession by the Transval. Failing a reasonable response from Kruger, Britain would take steps to secure a settlement. ${ }^{67}$ Rejection of this ultimatum was featured in the Australian press on 18 September under large headlines such as those in the Age: "Boers for War! - War Considered Inevitable". ${ }^{68}$ During the past four months the Transvaal question had shared prominence with the English tour of Darling's XI, the Dreyfus case, and, occasionally, Australian federation, but now the crisis dominated all other items.

Against this backdrop of heightened tension another colony moved to play its part in the tragi-comedy that was to lead to "the blooding of the pups". At this point Victoria assumed leadership of the Australian colonies, for a new government under William Lyne had gained power in New

\footnotetext{
67 Argus, 14 September 1899, p. 5. 68 p. 5 .
} 
South Wales early in September and was reluctant to make any decision on troop commitments without reference to parliament. It did not meet until 17 October. The shadow of William Bede Dalley and his unconstitutional action of 1885 hung over the New South Wales ministry. 69

But in Victoria another military man who considered that his time had come took action. Major-General Sir Charles Holled-Smith, military commandant of Victoria and senior army officer in the Australian colonies, had been in South Africa in 1881 and had experienced at first hand the great humiliation to British arms at Majuba Hịl. His personal enthusiasm for a war against the Boers was shown at the end of 1899 when he hastened back to England with the expressed hope that he would soon be on active service in South Africa. But for the present he was intent on getting the Australian colonies more fully involved.

In a press interview reported on 19 September, Holled-Smith revealed that "several weeks ago" he had suggested in a communication to the Victorian minister for defence that a cable be sent to the Imperial authorities inquiring whether Australian assistance was acceptable, and if so, what type of force would be preferred. W. McCulloch had not replied. The commandant favoured a federal force, and he exhorted Australians not to forget their fellow countrymen on the Rand. If Britain was prepared to go to war on behalf of the Uitlanders, surely Australia should do something when so many of her people were involved. ${ }^{70}$

Holled-Smith's statements probably moved the Victorian government to action. On 19 September the minister for defence directed that enrolling

69 Dalley committed N.S.W. troops to the Soudan campaign on executive authority only. He was subjected to much parliamentary criticism as a result.

70 Argus, p. 5. 
of volunteers from all branches of the services begin at Victoria Barracks. ${ }^{71}$ This was the first overt act of recruitment for war in South Africa by any colonial government in the Empire. On 20 September Holled-Smith worked out the practical aspects of recruitment with McCulloch. The two men also asked their premier to suggest to other colonial leaders that they send their commandants to Melbourne to confer on a scheme for a united Australian force in the event of colonial troops being required in South Africa. ${ }^{72}$ The premier, Sir George Turner, moved with great haste and telegrams went out on the day that Holled-Smith and McCulloch had conferred.

Other Victorian activity took the form of a cable on 20 September to the Colonial Office which read: "Many volunteers for South Africa. May we assume that charges will be borne by the Imperial Exchequer?" 73 This cable was another attempt to elicit a clear statement from Chamberlain on the financing of a possible Australian contingent. Turner was apparently reluctant to expose the rising Imperial loyalty of Victorians to the sobering facts of a budget deficit. More pertinent was Turner's cable of 27 September: "In event of United Australian force being formed for service in South Africa. What arm or arms should it consist of?"74 The request was the logical follow-on of Turner's marshalling the commandants into conference, and it would appear that the Colonial office cable of 3 October, accepting an Australian contingent and dictating its composition, was partly in answer to it, and partly in answer to the earlier communications of New South Wales, Victoria, and South Australia which had told of volunteers coming forward.

71 ibid, 20 September 1899, p. 7.

72 ibid, 21 September 1899, p. 5. The Age of the same date, p. 5, reported that the suggestion for a military commandants' conference was made by $\mathrm{McCu} 11$ och.

73 C. . $309 / 148$.

74 ibid. 
While Victoria had been making some headway in its attempt to ensure a federal contingent in case of war, Dickson in Queensland was making moves, overt and otherwise, to retain for his colony the distinction it had won in July. On 19 September he telegraphed Lyne, asking him what New South Wales was going to do. Queensland had made a troop offer but Dickson considered the the "moral effect upon all portions of the Empire would be much greater if the Australian Colonies took concerted action in the matter". ${ }^{75}$ Lyne replied the following day, sympathising with any move to give moral support to the mother country but declining to take any action that would incur expenditure without parliamentary sanction. ${ }^{76}$ According to a press report, Dickson next turned to Victoria. On 20 September, the day of Lyne's telegram, he suggested to Turner a meeting of military commandants in Sydney. The telegram was reported to have crossed that of Turner which suggested such a meeting in Melbourne. ${ }^{77}$

Despite his play for a combined colonial effort (with the initiative coming from Queensland), Dickson's next step seemed designed to set: Queensland apart from the plans of other colonies. On 22 September, aware of Victoria's initiative regarding the commandants' conference, he sent to the Colonial office a cable which was clearly intended to hasten a definite decision on Queensland's troop offer. It said in part: "Earliest possible information is desired by my Government whether their offer to send a contingent is likely to be accepted in order to obtain the necessary parliamentary supp1y". ${ }^{78}$ When the Queensland military commandant presented himself at the Melbourne conference a week later, he brought proceedings to a

\footnotetext{
75 N.S.W. Government Papers A.W.M., p. 39.

76. ibid.

77 Age, 22 September 1899, p. 5.

78 C. $0.234 / 68$.
} 
stalemate by insisting that Queensland's offer of troops, and the provisional acceptance of that offer, placed her apart from any scheme for a federal force. The Victorian minister for defence had to be called in to admonish Gunter, and in the process he drew attention to the contrasting co-operative attitude of the Queensland premier. Perhaps McCulloch only knew the half of it.

The commandants met in Melbourne on 29 September in what McCulloch happily regarded as "a federal incident of no small importance in the history of Australia". ${ }^{79}$ But the labours of these Imperial officers were anything but federal in spirit. The first day's proceedings showed that while Victoria, South Australia and Western Australia favoured a federal force, New South Wales and Queensland did not. French considered it would take too long for the various colonial governments to sanction a federal force and it would then arrive too late. Gunter thought that as there was no federal authority there could be no federal force. Colonel Stuart of South Australia argued that if the commandants acted in unison the premiers would soon provide a federal authority. And Holled-Smith, president of the conference, could achieve no agreement on this basic point. ${ }^{80}$ On the following day the commandants decided to pass on to the subject of pay and allowances. It was at this stage that McCulloch appeared on the scene and asked leave to address the conference. He had entertained the commandants at a luncheon at Parliament House the previous day and had then left the city. A message from a concerned party (Holled-Smith?) had brought him back to remind the conference of its purpose - to draw up a scheme for a united Australian force for presentation to the colonial governments. McCulloch

\footnotetext{
79 Age, 30 September 1899, p. 9.

80 N.S.W. Government Papers, A.W.M., p. 50.
} 
was particularly severe on Gunter, asking him why he had come to Melbourne at a11. ${ }^{81}$ The chastened military men returned to their appointed task and by 5 October had drawn up a plan for an Australian contingent of 2053 officers and men. (See Appendix A). The conference was of the opinion that if a sufficiently large force representing all arms were to be sent, it could remain intact as an Australian contingent capable of acting alone or in concert with regular troops. ${ }^{82}$ So far as the composition of the contingent was concerned, the commandants seemed to have a better appreciation of the needs of a South African campaign than the War Office; and their desire for a unified and self-sustaining Australian force was commendable. The sensitive question of the command and second-in-command was left to the premiers, and the appointment of other officers was left to a projected further meeting of the commandants in Sydney. That meeting never eventuated, nor did the commandants proceed any further with detailed planning after the receipt of Chamberlain's cable of 3 October, for this prescribed a fragmentation of the Australian military effort. (See Appendix B).

The Colonial office cable which brought an abrupt end to the concept of a federal force was a fascinating document. Considering that the "offers" of New South Wales, Victoria and South Australia had been so nebulous, the Home government did a pretty fair job of presuming a definiteness that had not existed. The cable acknowledged"the patriotic spirit exhibited by the people of Australia in offering to serve in South Africa", and furnished "information to assist organisation of forces offered into units suitable for military requirements". By prescribing units of 125 men, with two units from each of New South Wales and Victoria and one unit from South Australia, and by stipulating that the units were to be officered by no-one above the rank of major, the War office was clearly envisaging token

\footnotetext{
81 ibid, p. 51

82 Daily Telegraph, 6 October 1899, p. 5.
} 
forces which could be attached to Imperial regiments. ${ }^{83}$

The stated preference for infantry was also regarded by some as another means of placing the colonial irregulars where they would be least inconvenient. The War office conditions stated that the units "may be infantry, mounted infantry, or cavalry. In view of numbers already available, infantry most, cavalry least, serviceable". The request was rather a strange one considering the vast distances to be covered in South Africa, the small proportionate numbers of British cavalry, and the fact that the Boers would fight mounted to a man. The Times History suggested that the amazing dispatch became comprehensible only "if for 'most serviceable' we substitute the more direct phrase 'least troublesome'". ${ }^{84}$. The same writer also claimed that the War Office was decidedly cool about the colonial offers, feeling that they had enough regulars for the task without calling on colonials who were difficult to manage and of little use. He alleged, also, that it was only after Colonial office insistence that the War Office accepted the colonials. ${ }^{85}$

At the Royal Commission on the South African War, Lord Lansdowne, Secretary of State for War, defended the War Office preferences by claiming that "cavalry" was not meant to include "mounted infantry", but he did not say whether "infantry" included "mounted infantry". ${ }^{86}$. General Sir Redvers

83 The Queensland offer was accepted by a similar but separate telegram, much to the delight of Dickson and Gunter one would think. Tasmania and Western Australia were not included in the common. telegram to the other colonies because neither had made any sort of offer, but it was generally assumed that they would form part of any contingent sent from Australia.

84 The Times History, Vol. II, p. 117.

85 ibid, p. 116.

86 "Report of His Majesty's Commissioners Appointed to Inquire into the Military Preparations and Other Matters Connected with the War in South Africa"; being Vols. 40-42 of Reports from Commissioners, Inspectors and Others (London, 1903), Vol. 40, p. 349. Hereafter Elgin Commission, Vols. 40-42. 
Buller was also a party to the decision and he claimed that he had in mind that all colonials could ride and he would turn them into mounted infantry. What he did not want was a small force of "irfegular cavalry" such as the English Yeomanry. ${ }^{87}$ The sincerity of these statements is supported by the fact that the offers of mounted infantry by New Zealand and Queensland were accepted without qualification. And after all, the commandants' plan was to send 1,010 infantry and 935 mounted men. Place these figures against the 580 infantry and 625 mounted men who actually went with the first contingent and we see that the War Office conditions did little to alter the proportional composition of the Australian force.

Many years later there came an echo of the affair when Senator C.F. Cox, former commander of the Aldershot detachment of the New South Wales Lancers, replied in the Senate to a letter to The. Times of $21 \mathrm{July}$ 1933 from Sir Frederick Robb, a former major-general in the British Army. Robb set out to remove the stigma which he claimed surrounded the name of Lord Wolseley, a former commander-in-chief, because of the infantry-preferred cable. According to Robb, Lord Wolseley thought it an admirable idea to test the quality of colonial troops by exercising the Lancers with regular cavalry upon their arrival at the Cape. ${ }^{88}$ This was allegedly done and Sir George White, who was commanding at Cape Town, was supposed to have sent Wolseley an account of "the almost comic shortcomings of the detachment". ${ }^{89}$ At that time, Robb continued, the War office was considering the offers of the colonies and Wolseley suggested that because of White's "adverse" report the colonies should be told to send only dismounted troops. Replying to the criticism, Cox quoted a letter he had written to The Times disbelieving

87 ibid, p. 78. Could he also have had in mind another body of "irregular cavalry" - the New South Wales Lancers?

88 The Lancers had just completed six months of exercises and tournaments with British regular cavalry units.

89 The words are those of Robb. 
that White had ever inspected the Lancers and claiming that even if he had, his criticism was answered by the regiment's meritorious service in South Africa, which Cox went on to extol at some length. Robb's allegations could have been refuted by a simple exercise in chronology. The cable accepting Australian troops was dispatched on 3 0ctober. The Lancers were then still in England. 90

The Australian colonies seemed almost relieved that each could now go ahead with its individual war effort. New South Wales was an exception. Lyne tried desperately to stop the other colonies, particularly Victoria, from making individual and official commitments of troops, for New South Wales was in the frustrating position of being the only colony whose parliament was not in session, ${ }^{91}$ In particular, Lyne tried to contain Victorian exuberance by urging that the commandants' report be kept secret until considered by all governments. Turner's reply was that he "deemed it wise to give publicity to the report". ${ }^{92}$ He did; but for some reason refrained from making public the text of the Colonial office cable. The Victorian press had to get that information from New South Wales where it had been released by a disgruntled Lyne only because Dickson had already given the text of a similar cable to the Queensland press!

Faced with a restive military force, and the certain knowledge that New South Wales was falling quickly to the rear in demonstrations of Imperial loyalty, Lyne was at last moved to circumspect action in order to counter criticism. On 30 September, Lord Carrington, honorary colonel of the New South Wales Lancers and a former governor of New South Wales, had cabled the Lancers' headquarters at Parramatta that the Aldershot men had

\footnotetext{
90 C.F. Cox Papers, A.N.L., MS37; also C. of A.P.D., 1933, Vol. 141, p. 3752-3.

91 N.S.W. Government Papers, A.W.M., p. 41.

92 ibid, p. 44; telegram to Lyne of 5 October.
} 
volunteered for service in South Africa. He hoped the government would "sanction this patriotic offer". 93 The detachment of Lancers was at that time about to embark for Australia via the Cape, and their commandant at Parramatta sought permission for them to disembark in South Africa. In his memorandum to the chief secretary, Lieut.- Colonel Burns fashioned an argument suited to the situation. Dropping the Lancers at Cape Town would not involve the government in any expense; and here was a body of Imperialtrained cavalry who would do credit to their colony and be the first colonial troops to 1and in South Africa. ${ }^{94}$ Lyne gave tentative approval.

On 6 October the Argus was able to announce with confidence: "It can now be definitely said that Australia will be represented in the war in South Africa". 95 Thanks to the implications of the commandants! conference and the Colonial office cable, the active recruiting of volunteers, the chartering of troopships and other martial preparations, the colonies could not doubt that they had reached a point of no return. Yet even as late as the cable of 3 October accepting Australians for war, the will of the people as expressed through their parliaments had still to be made known. Debate now commenced, but under such handicaps that it became a travesty of democratic discussion.

On 5 October Western Australia and South Australia introduced legislation to send contingents. The debate in the Western Australian Assembly was extremely short. The motion was introduced by the premier, Sir John Forrest. It expressed loyalty to the Queen, sympathy for Her Majesty's government, and suggested co-operation with other colonies in

\footnotetext{
93 N.S.W. Government Papers, A.W.M., p. 41.

94 ibid, pp. 42-3.

95 p. 4.
} 
dispatching a force if war should be declared. ${ }^{96}$ An excellent case against conflict with the Transvaal came from Moran, member for East Coolgardie. He stressed the ignominy of war with such a diminutive foe; he extolled the sturdy virtues of the Boers, who had created a nation out of the wilderness and were now expected to hand it over to Britain by the franchise device. They were fellow Christians, fellow Europeans and fellow colonists, whose only fault was perhaps ignorance. And having said a11 that he voted for the motion. Even more disquieting was the response of the premier to a member who asked what was really known in Western Australia about the justice or injustice of the impending war. "We do not want to know", said Forrest. ${ }^{97}$ The motion was carried on the voices.

In South Australia, although a motion to dispatch a contingent of 125 volunteers was introduced in the Assembly on 5 0ctober, two adjournments extended debate to 12 october. The attorney-general, in moving, exploited the earlier Queensland offer, the more recent New Zealand offer, 98 and the motion before the WesternAustralian parliament. He conceded that Britain did not really need troops, but regarded the offer as an expression of sympathy in "a period of some Imperial anxiety"; and he quoted the proverb, "Who gives quickly gives twice", 99 which would have been more truthfully expressed as, "Who gives quickly gives before the others".

96 W.A.P.D., 1899, Vol. XV, New Series, p. 1556. Forrest's motion, the terms of which he telegraphed to the other colonial premiers on 4 October, was probably fashioned before he received news of the Colonial office cables to New South Wales, South Australia, Victoria and Queensland.

97 ibid, p. 1558.

98 On 28 September the New Zealand Assembly voted 51 to 5 to send 200 mounted riflemen at the colony's expense should they be needed.

99 S.A.P.D., 1899, pp. 608-9. 
The influence of press and public opinion on the South Australian debate can be clearly inferred. One member regretted that the subject had not been discussed in committee as a matter involving finance, for anyone "taking the opposite view to the Premier was liable to be accused of all sorts of want of patriotism and false sentiment".100 Another regretted that the press was already attacking "little Australians", and referred to a letter from a friend who hoped that he would oppose the motion, but suggested he preface his opposition with the singing of God Save the queen in order that this stand would not be construed as disloyalty. ${ }^{101}$ Another, who had referred to the volunteers as "feather-bed" soldiers, a common term of contempt at the time, apparently came under such criticism that he spent much time later in the debate praising the soldiers' potential and trying to explain away his comment. ${ }^{102}$

A practice which affected the quality of debate in most colonial parliaments was prominent in the South Australian legislature. A number of speakers withdrew their opposition to sending a contingent because they considered that the colony had already been committed by executive action and was therefore honourbound to participate. There was a fair amount of truth in the claim, of course, and quite capable politicians used it as a substitute for reasoned argument on the morality of the war. Sir John Downer was one who deprecated the action of the government in moving when it did, but he asked members "not to discount both Britain and the Empire in the eyes of Europe" by rebuffing the initiative taken, ${ }^{103}$ One member recited a

\footnotetext{
100 ibid, p. 609, H.A. Grainger.

101 ibid, p. 621, E.L. Batchelor.

102 ibid, p. 652, E.A. Roberts. Many politicians underwent drastic changes under pressure of public opinion, but none went so far as Roberts. Despite his opposition to the war and his denigration of the military forces, he volunteered for service with the Imperial Bushmen's Corps and went to South Africa as a lieutenant.
}

103 ibid, pp. 630-1. 
few lines of doggerel to illustrate Downer's stand, and in so doing described the mental agony of many a confused politician who was confronted with the awesome prospect of involving his country in international war.

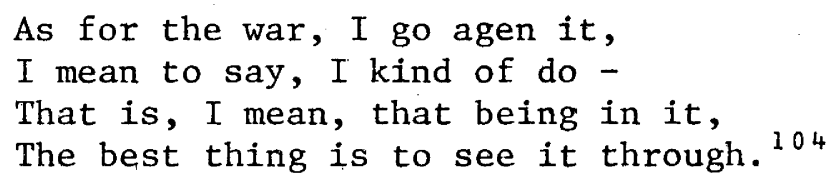

It is very questionable whether Kingston had acted on any definite indication of the extent of military fervour in the colony when he sent that cautious cable of 4 September. When we recall the imperial ardour that Kingston demonstrated throughout August, as he pestered Reid and other colonial premiers to make a gesture of loyalty to the homeland, we realise that he would have been prepared to act on the most slender evidence; and that is what he appears to have done. Initially, when pressed in debate, Kingstom had to admit that he had no idea of the number of volunteers prior to 4 September, "He was dealing with the House with every candour, but he could not say whether ten persons had volunteered". 105 Later in the debate he quoted a memorandum from the acting military commandant stating that 100 men had offered verbally in July and August. ${ }^{106}$ In his speech-in-reply, however, Kingston defended his action not so much by reference to military initiatives, as to the offers of other colonies. Was South Australia to stand out? ${ }^{107}$ The motion was carried 18 to 10 with twelve pairs, the premier choosing to ignore the plea of Tom Price, Labour leader, who wanted Kingston to withdraw the motion and thus go down in posterity for his courage. ${ }^{108}$

\footnotetext{
104 ibid, p. 657, F.W. Conybear.

105 ibid, p. 620 .

106 ibid, p. 659.

107 ibid.

108 ibid, p. 628.
} 
of all the colonial upper houses, those bastions of conservatism and representatives of property, the South Australian Legislative Council was the only one to show any semblance of legislative responsibility. In the other colonies, motions to send contingents were treated as a mere formality, with members commonly deploring any move to debate the issue. But in South Australia the motion was passed in the Council only on the president's casting vote. Reasons for this atypical opposition were varied, Several speakers either ridiculed the inconsequential size of the proposed force or held that it was not needed; other resented the move by the executive before parliament was consulted; and still others opposed because on the eve of federation small colonial contingents, which would soon lose their identity, were being raised. Support for the contingent was not expressed with any obvious warmth or logic. The mover of the motion put forward as a first reason for going to war the "great number of Australians in the Transvaal". ${ }^{109}$ He also favoured Australian participation as an answer to those who were disposed "to sneer not only at Australian troops, but at Australians generally as inferior to the old race". ${ }^{110}$ When he spoke in reply, the chief secretary could only answer the opposition by claiming that South Australia had to follow the example of Queensland, New Zealand, New South Wales and Victoria. ${ }^{111}$

In the meantime, on 10 October, the Tasmanian lower house had approved the dispatch of a contingent. Again a colony had been committed by its parliamentary executive which on 8 october had cabled to the Colonial Office an offer of assistance. The government had also authorised the enrolment of volunteers. Parliament itself was a little more reluctant

\footnotetext{
109 S.A.P.D., Leg. Council, 1899, p. 146.

110 ibid, p. 147.

111 ibid, p. 155.
} 
and the premier, Sir Edward Braddon, anxious to complete the contingent business before he faced the no-confidence motion that was to bring him down, reduced his request from $£ 7,000$ and 125 men to $£ 4,500$ and 80 men to ensure that the motion was passed. An inclination to quibble over the cost of the contingent roused the ire of the Launceston Examiner, which expressed devout thanks for oncoming federation, for "while pettifogging representatives were haggling over the odd halfpence an enemy might be at our gates". 112 Also on 10 October, following a one-day debate that was distinguished mainly by the utterance of imperialist platitudes, the Victorian Legislative Assembly approved the dispatch of a contingent. In submitting the motion Turner ran through a gamut of excuses for going to war. He referred to the ill-treatment of Britons by Boers ${ }^{13}$. to the need to give a practical demonstration of loyalty and Imperial unity; and to the "very large number" of Australians in the Transvaal. As to the true merits of the case, he could only rely on the British government, which would be fully apprised of the situation. In addition the parliamentary opposition, press and people

11211 October 1899 , p. 4. The Age reported that two members voted against the motion. 13 October 1899, p. 6.

113 Turner's information on Boer "brutality" would have come from that morning's Age, which carried as headlines: "Atrocious Boer Brutalities - Women and Children Maltreated - Spitting in Ladies' Faces - Children Dying in Cattle Trucks". The reference was to an incident in the general exodus from the Rand of Uitlander families. According to the London cable, a train carrying 70 women and children was shunted into a siding and left for a considerable period, during which time two children were said to have died. It was also claimed that "several women gave birth to children during their terrible journey". (Age, 10 October 1899, p. 5). Undoubtedly the exodus meant hardship for many families, but it would have been difficult to sustain a charge of Boer brutality in relation to it. The London report was given prominence by a big section of the Australian press, and it played a significant part in the parliamentary debates on the first contingent. 
were behind the Home government so it could fairly be said that the British cause was a just one. ${ }^{114}$

The most virulent attack on the motion came from John Murray of the Labour party; not W.A. Trenwith as one might have expected, for the Labour leader's devotion to Empire apparently counted for more than the prevailing mood of his party. Unfortunately Murray fell into extremes in attacking the motion. He regarded the "military urge" in Australia as being inspired by the press, the war in general as being inspired by the capitalists, and the role of the Australian volunteers as little better than "wood and water joeys". ${ }^{15}$ It was left to Henry Bournes Higgins to present a reasoned argument, but the ears of parliament, press and people were not then attuned to the sweet music of logic, and for his pains the member for Geelong was discarded by his predominantly middle-class constituents at the next election. Higgins saw the war as one in which Australians had had no voice, and over which they would have no control. Whether the struggle was a just one or not was of paramount importance to him, yet as he saw it the Boer side had not been put by the Australian press, which got its information from a single source, The Times correspondent in South Africa, whose reports were bought by a combination to which, Higgins alleged, all Melbourne and Adelaide and some Sydney papers belonged. ${ }^{116}$ Among other speakers common themes were the debt of the colonies to "the old grey mother", the support of England as security insurance, and the support of England "right or wrong". There was a tendency among Labour members to regard the untried Australian soldiers as being destined for undistinguished service in South Africa, and no corresponding tendency among supporters of the motion to claim otherwise. The vote was 67 to 13 in favour of the contingent.

\footnotetext{
114 V.P.D., 1899-1900, Vo1. 92, pp. 1727-8.

115 ibid, pp. 1731-4.

116 ibid, pp. 1777-9.
} 
Debate in the Queensland Legislative Assembly began on 11 October and went on for four days before the vote was taken on 18 October. When the premier, J.R. Dickson, put forward a motion renewing loyalty to the Crown and offering troops as evidence of support for long-suffering Transvaal subjects, one might think he would have acted with some trepidation. In the view of A. Dawson, leader of the Labour opposition, Dickson had virtually declared war on the Transvaal in his infamous offer of July without consulting the representatives of the people; ${ }^{117}$ and Dickson might well expect strong opposition from Labour if the virulent attacks of its organ, the Brisbane Worker, could be taken as any indication. But he was an astute politician, and if he had taken a long chance on public opinion in July, the odds were now much more in his favour, for, as Dawson painfully observed, there was a "wave of jingoism ... passing all over the country". ${ }^{118}$

The premier defended executive action in July on the questionable grounds that a crisis prevailed at the time, and if he had not acted before parliament met in September "the emergency might have passed away". Time and again in his speech he sought acceptance of his fait accompli on the grounds of the great prestige which had accrued to the colony through its having led the way. The Queensland offer of troops, he announced, "has placed Queensland in the foremost rank among the Australian colonies, and it has stimulated $\overline{117}$ Q.P.D., 1899, Vol. LXXXII, p. 348.
118 ibid, p. 344 . 
her sister colonies to go and do likewise". ${ }^{19}$ Other reasons he gave for sending a contingent were the "harsh and brutal treatment" of the Transvaal refugees as reported in the press, ${ }^{120}$ and the need for actual warfare to train Queensland troops. ${ }^{121}$

Dawson strongly opposed sending a contingent because he did not see the Empire in any danger, and he considered that the money spent "in sending a mob of swashbucklers to South Africa to show off their uniforms" would be better used for hospitals and libraries. These were inflammatory words to a community which was in the process of re-adjusting its attitude to soldiers, but Dawson blundered on. He could have no respect for any man volunteering for the Transvaal. Such a person was merely a "cur", rushing in to take a bite at the "little poodle" that the "large mastiff" was attacking. ${ }^{122}$ This was the most outspoken attack on the military by any Australian

119 Another person influenced by Dickson was the governor of Lagos, who wrote to the premier saying he had followed his example and offered 300 men to the Home government. They would, of course, have been too dusky to participate in this white man's war.- Age, 14 October 1899, p. 10. Dickson's offer also had an echo in the Canadian House of Commons when a Colonel Hughes commended the Queensland offer and urged that Canada, whose defence forces were already volunteering, should send a regiment.Argus, 15 July 1899, p. 9. Colonel Hughes, in the face of government inaction, set about raising a contingent in case of war. On 3 October the Canadian Military Institute came out openly in support of a contingent. (Hutton was military commandant at the time). - Creswicke, South Africa and the Transvaal War, Vo1. 3, pp. 138-9. In July the Canadian government had expressed its sympathy with the Uitlanders and its faith in Imperial policy, but it was reluctant to do little else. On 13 October, in view of public clamour which was highlighted by telegrams from the mayors of 300 towns and cities urging the government to action, Sir Wilfrid Laurier waived constitutional principles (parliament was not in session) and issued an order-in-council which allowed for the raising and dispatch of 1,000 volunteers. War had officially begun on 12 October. - The Times History. Vol. III, pp. 3840 .

120 See note 113.

121 Q.P.I., 1899, Vol. LXXXII, See pp. 339-43 for Dickson's speech. 122 ikid, p. 347. 
politician, and Dawson was to rue the day. The Brisbane Courier labelled him and other Labour members who opposed the contingent as Boer sympathisers, and berated Dawson for the "scurrility" of his attack on the volunteers.123 Worse was to follow. The Worker alleged that for a week following Dawson's speech "a gang of bullies" gathered nightly outside his house, frequently while he was absent in parliament, throwing stones on the roof and through windows, and "insulting his wife and family with vile and low scurrility". ${ }^{24}$ When the debate on the dispatch of the second contingent took place in December, Dawson seconded the motion. British defeats had put a different complexion on the war by then, but one wonders what part physical intimidation played in Dawson's change of heart.

Realising that the Dickson government was most vulnerable on the point of a constitutional aberration, Dawson based an attack in this direction on an amendment which retained the loyal expressions of Dickson's motion but registered disapproval of the action of the executive in offering troops in July. There was strong support from both sides of the house on the matter of Dickson's "impropriety" and the amendment was only lost by 28 to 39 . Debate on the motion resumed but, with the constitutional "red herring" removed, soon petered out without any real attempt to appraise the developing conflict in South Africa. The now guarded, and even conciliatory, references of Labour members to the volunteers indicated a public rebuttal which extended far beyond the editorial comment of the Brisbane Courier. At $4.30 \mathrm{a} . \mathrm{m}$. on 19 October the motion was carried on the voices, and was followed by what had become a ritual in colonial parliaments - three cheers for the Queen! ${ }^{25}$ When on the 17 October the New South Wales Legislative Assembly began debating the dispatch of troops, all other colonies but Queensland had

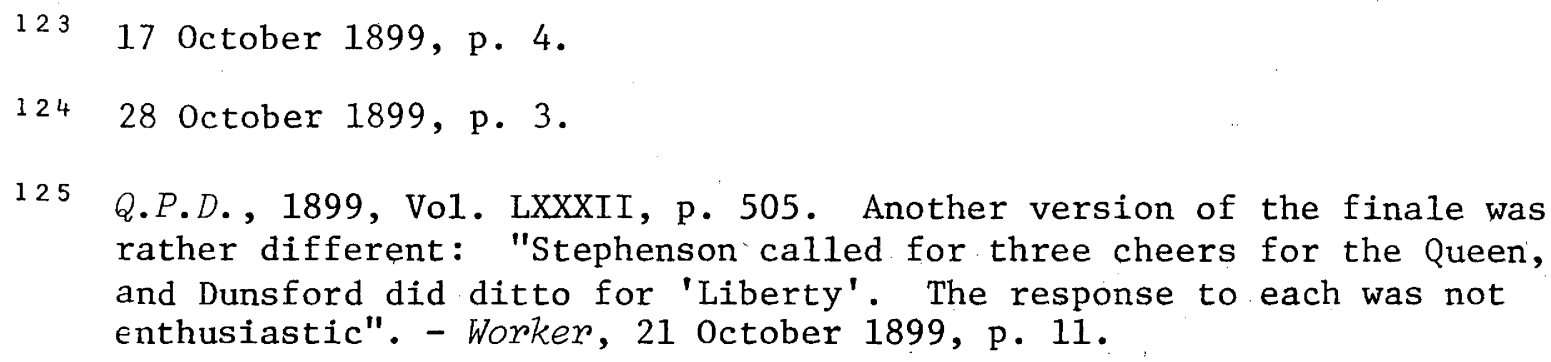


decided to send contingents, and even in Queensland the debate was well advanced and obviously moving towards commitment. Incredibly, the premier used this situation as a primary casus bezli. When $W$. Lyne moved for the equipment and dispatch of a force for service with the Imperial Army in South Africa, he made no attempt to justify New South Wales participation other than on the grounds of the need to demonstrate Imperial solidarity in the eyes of the world, and the need to emulate the other colonies. It would be "singular indeed" if the mother colony stood back. ${ }^{126}$ The Bulletin saw Lyne as "a dry, elderly politician, who had waited long and patiently ... before coming into his kingdom". 127 The mediocrity implied clearly emerged in Lyne's speech, which omitted any reference to the principles or morality involved in going to war. When questioned on this omission, the premier declined to debate the merits of the case. The Imperial government had entered on war and it was the duty of New South Wales to support it. ${ }^{128}$ Lyne's prosaic handling of the issue was not lost on G. Reid, now leading the opposition parties. He undertook to supply something of the "high ground of principle" he found lacking in Lyne's appeal to the house. Reid failed, however, to fashion a principled case for intervention in South Africa because, as on a previous occasion, he found something good in both sides. He praised the "magnificent courage" of the Boers and conceded that they were "fighting for the integrity of their own land", but he still upheld that ideal of the Imperial government which sought to protect a Briton wherever he might stray. ${ }^{129}$ It was left to others to make profounder observations in a debate which was to extend over three full days. W.M. Hughes typified a more honest and more discerning approach to

126 N.S.W.P.D., 1899, First Series, Vol. C, p. 1379.

12723 September 1899, p. 8.

128 N.S.W.P.D., 1899, First Series, Vo1. C, p. 1379.

129 ibid, pp. 1380-93. 
the Transvaal crisis. He deplored the lack of any official source of information from which the merits of the case could be learned. Of the Uitlander grievances he suggested that men had to be amenable to the laws of the country to which they went voluntarily. He defended Kruger's stand, for if the Transvaal did not fight it would be "blotted out of the map of Africa by the slow and insidious process of political reform". A staunch imperialist, Hughes sought refuge from charges of disloyalty by ranging himself alongside Chatham, Fox, Bright and Gladstone - men who had also stood out against wrong wars. 130

The speech of W.A. Holman is less interesting in itself than in its consequences. It was in large part a tirade against swindling speculators on the Rand, Cecil Rhodes, British action against inconsequential powers, and soldiers who were going to fight for they knew not what just to improve their musketry. In the midst of it all Edmund Barton introduced into the chamber a little game that members had been diverting themselves with in the lobbies. He asked Holman if he wanted the British or the Boers to win. The member for Grenfell replied that he would support his country in a just cause, but as be believed from the bottom of his heart that this was the most iniquitous, most immoral war ever waged with any race, he hoped the English may be defeated. ${ }^{131}$ Holman's answer caused uproar in the House and reverberations in a large section of the city and provincial press, the Labour member serving as a focal point for much of the ill-feeling towards his party which the debate had engendered. So sharp was the criticism that Holman tried to redeem his position by claiming that he had expressed a wish for Boer victory over the Chartered Company and not over England. This mollified his parliamentary colleagues, but sections of the public remained unimpressed. During a public lecture by Holman in Hobart on "The Labour

\footnotetext{
130 ikid, pp. 1428-36.

131 ibid, p. 1466.
} 
Movement and Militarism", the audience got out of hand. A group of sailors burst into Sons of the Sea the gaslights were turned off, Holman was tipped off the platform and assaulted, and as he was escorted away the audience broke into the anthem. The people had come to judgement. Holman's more discerning patriotism was not of the times. ${ }^{132}$ Later, as a by-play to the celebration in Grenfell of the relief of Mafeking, Holman was burned in effigy; an experience which would have been no less painful to him than the clouts of the tars. ${ }^{133}$

The remainder of this, the most thoughtful debate among all the colonial parliaments, could be reduced to a number of generalizations. It was widely held that Australian troops would not be of any material assistance, but would merely symbolise Imperial loyalty and solidarity in an antagonistic world. Reid's July "offer" of troops was put forward to some extent as a pretext, for non-debate, but the factor most inhibiting discussion was a widespread acceptance, even by men of the stature of Barton, that the rights or wrongs of the war could not be debated because parliament did not possess the necessary knowledge of the Transvaal situation.

The most honest of all speeches, perhaps, came from one John Dacey. He said, "I am going to vote for British supremacy in South Africa". He carried no brief for the "transient" Uitlanders, but his sympathy with the Boer cause extended only to that point where they wished to become paramount in South Africa. ${ }^{134}$ The vote was 78 for and 10 against. All the negatives were Labour members, but seven other Labour members present had voted for the motion. These included James McGowen, the Labour leader, who had

\footnotetext{
132 Grenfell Record, 27 January 1900, p. 2.

133 ibid, 26 May 1900, p. 2.

134 N.S.W.P.D., 1899, First Series, Vol. C, pp. 1573-4.
} 
equated loyalty to the cause of Empire with loyalty to the cause of labour; you did not question if it was right. ${ }^{135}$

And so the last obstacles to Australia's going to war were removed. The legislatures had given their blessing to a movement that had reached a point of no return even before a word was uttered on the subject in any colonial parliament. No individual colony could possibly have stood apart from the eager rush to support the Empire, and few politicians had either the conviction or the courage to oppose involvement in the Transvaal. The only significant opposition came from the labour parties, which, despite division within their ranks, managed to introduce into the debates some of the deeper issues involved in joining in the war. ${ }^{136}$

During the debates the conservative press had constantly played its hand for commitment, directly by editorial comment, and indirectly by denigration of the Boers and by reports of military enthusiasm and preparations for war. The radical press had constantly over-played its hand against commitment by seeing the war due entirely to the machinations of capitalists and military officers. All too rare were thoughtful leaders such as the one which appeared in the Broken Hill Barrier Miner on 13 October (although it accepted without question the current reports of Boer ill-treatment of women and children). This newspaper questioned the rejection by Britain of the Boer request for arbitration, and drew attention to Australia's role in the crisis. It suggested that Australia's responsibility should have been to encourage its powerful protector to accept arbitration, but instead, 135 ibid, p. 1553 .

136 Although several Labour members were reported to have wanted to support the motion before the South Australian Assembly, a majority decision taken by the party held all members to the negative. - Sydney Daily T'elegraph, 13 October 1899 , p. 6 . Such was not the case in New South Wales where R. Sleath and A. Griffith clashed over the contingent issue and both expressed a willingness to take up the matter outside. Sleath charged Griffith and Holman with having ignored their pledge of allegiance to party majority opinion. - Age, 21 October 1899, p. 9. 
"Have we not rather encouraged her to look to arms?" The lack of knowledge of the issue was also questioned, as were Australia's motives: "Parliaments have voted money, not because they have inquired and believe England right, but because they want to share England's greatness and England's glory". ${ }^{137}$

Few individual citizens came forward to question government decision on the war, for already press and public opinion were intolerant and repressive. G. Arnold Wood, professor of history at Sydney University, was one man informed enough and courageous enough to attack the Daily Telegraph when it sought to dismiss all opposition to the war as the work of a few "1ime-1ighters". Wood asserted in a letter to the editor that opposition in England was widespread (he made no such claim for Australia), that it mainly had a Christian basis, and that for an empire built on "principles of righteousness" the war that England was now entering on was an unjust one. ${ }^{138}$ A.B. Piddington, later a prominent jurist, wrote to the same paper pointing out that siding with England in a quarrel that was none of Australia's making was a violation of "the sane and just policy of the Monroe Doctrine for Australia"; and he suggested that if Australia had to have her baptism of blood one day "let it be blood that will be spilt like that of the Boers, in defence of freedom and fireside, and not in a war of pillage and despotism, which must end without glory, because it begins without right". ${ }^{39}$ But the warnings of these men were lone voices that were lost in the tumult. Henry Lawson, in one of his rare comments on the war, looked at the situation just as the last of the colonial parliaments endorsed commitment, and tried to work out the mania that gripped the land. Lawson's statement is worth quoting at some length, not only because of his stature,
137 p. 2 .
13819 October 1899, p. 3 .
13929 September 1899 , p. 7. 
but also because of the truth of much of what he said:

What does it all amount to? Only this: That, because of the craving for the sensational born of the world's present social system - the mad longing for change, intensified in Australia by the hopeless flat monotony of the country and its history - some of us are willing - wilfully, blindly eager, mad! - to cross the sea and shoot men whom we never saw and whose quarrel we do not and cannot understand. Our cry is 'For England!' or 'Blood is thicker than water!' and so we seek to blind and deceive ourselves as fools who are unanimous in their eagerness to sacrifice right, justice, truth everything, to satisfy their selfish craving for what they consider a picnic - to have 'some fun' - to have a spree. ${ }^{140}$

In the introduction to his Collected Plays, Arthur Miller discusses the phenomenon of McCarthyism and its affinity with the witch-hunts of old Salem. What he says seems highly relevant to the Australia of 1899. Miller speaks of a sense of guilt pervading post-World War II American society because men thought they were not as "Rightist" as they should be. He saw forming "a kind of interior mechanism of confession and forgiveness of sins which until now had not been rightly categorized as sins". But to his greatest horror he saw accepted "the notion that conscience was no longer a private matter but one of state administration". He saw men "handing conscience to other men and thanking other men for the opportunity of doing so". 141

And so perhaps it was that in 1899 Australians began to doubt if they were loyal enough; perhaps they harboured an amount of sympathy for the Boer cause which must be exorcised. Such a point of view could be argued in the light of the exaggerated behaviour of the times. For now enlightened. editors closed their eyes to truth and justice and humanity; mild men of

\footnotetext{
140 Buzletin, 21 October 1899 , p. 8 .

14.1 Arthur Miller, Collected Plays, (London, 1965), p. 40.
} 
God became hysterical advocates of a war of conquest; politicians in the most advanced democracies in the world put aside their 1iberal principles for the sake of Empire, while those who did not abjectly recanted in December their sins of October; and the people, who by repute gave everyone a 'fair go', engaged in witch-hunts against real or imaginary "pro-Boers". 


\section{CHAPTER II}

\section{PREPARATIONS FOR WAR}

The Colonial office cable of 3 October 1899, which accepted colonial "offers" of troops and laid down the composition of the Australian contingent, also stipulated that troops were to embark "not later than 31 october". ' Why the British authorities should have wished to get the token forces of colonial irregulars to South Africa so quickly is a matter for conjecture; but one result was to put to the test colonial military organisation and ministerial competence. Parliamentary approval for the despatch of troops was given between 5 and 19 October, and, although preparation had begun before then, it is to the credit of ministers and military that 1200 men with horses and equipment were embarked for war between 28 October and 5 November.

The Home government's request for units of 125 men (two units to come from the larger colonies and one from the smaller), freed the colonies of the need to attempt co-operation with one another, and accordingly they set about raising their separate forces. In the light of earlier military enthusiasm, this should have been an easy task, but in fact some colonies had difficulty in filling their units in the given time.

New South Wales, the leading military colony, with 7788 on the muster rolls of its defence force at the end of $1898^{2}$, had no trouble meeting its quota of 250 men although a majority of serving members chose not to volunteer at this stage. The difficulty lay in deciding which regiments would be represented, and competition for the relatively few places was so keen that the colony eventually sent a force of 450 .

\footnotetext{
1 Daily TeZegraph, 6 October 1899, p. 5.

2 T.A. Coghlan, The Wealth and Progress of New South Wales, 1898-9, (Sydney, 1900), p. 209.
} 
The officers commanding the New South Wales Lancers, the New South Wales section of the Royal Australian Artillery, and the New South Wales Army Medical Corps were very anxious that their regiments should experience active service and in response to their initiatives in offering detachments, ${ }^{3}$ William Lyne took steps to determine the composition of the New South Wales contingent. In a cable of 7 October to the Colonial Office he confirmed the offer of the Lancer squadron at Aldershot subject to parliamentary approva1. Four days later, under pressure from French, a Royal Artillery officer, Lyne offered the field battery. ${ }^{4}$ On 13 october he offered the medical detachment, subject to the approval of parliament. ${ }^{5}$ Had these units alone formed the first contingent, the great majority of the defence forces of New South Wales would have been without representation. Apparently this did not concern Lyne who was attracted by the prospect of the Lancers being the first Australian unit to arrive in South Africa, and also by the cost factor. The pay and maintenance costs of the R.A.A. had already been provided for in the Estimates. When Lyne introduced the motion to send a contingent, he spoke in favour of New South Wales being represented by the R.A.A. and the Lancers on the grounds of economy. ${ }^{6}$ George Reid, leader of the opposition, scorned Lyne's preoccupation with cost, and drew his attention to the recommendations of the Colonial Office cable. ${ }^{7}$ Probably Reid's attack, along with War Office rejection of the field battery offer and the agitation of other regimental commanders, led the New South Wales cabinet and French to plan a different contingent.

3 New South Wales Government Papers, A.W.M., pp. 39, 41, 46.

4 Correspondence of New South Wales Governor with Colonial Office, C.0. 201/625, A.N.L., Cable to Colonial Office, 11 October 1899.

5 ibil, Cable to Colonial Office, 13 October 1899. Lyne had no intention of doing a "Dalley".

6 N.S.W.P.D., 1899, Vo1. C, p. 1376.

7 ifjid, p. 1381. 
On 21 October Lyne reported that the colony would send 125 mounted infantry, 125 infantry, 86 medical corps, and the squadron of Lancers. ${ }^{8}$

This permitted New South Wales to embark some of its keenest soldiers. The Mounted Rifles establishment was 400 , located in eight halfsquadrons at Molong, Bathurst, Picton, Camden, Bega, Forbes, Tenterfield and Inverell. The regiment was a militia unit, receiving twelve to sixteen days training a year at the rate of eight shillings for a full day's attendance. The government supplied arms and uniforms, the troopers their own horses and equipment. By 25 October 140 volunteers from this regiment had been given a local preliminary medical test and were on their way to Sydney. Only 100 of these were to be selected, for the remaining places in the mounted infantry unit were to go to the Australian Horse. ${ }^{9}$ A list of the 129 officers, non-commissioned officers and men who formed this unit shows that only eight of the soldiers were married. The average age was twentysix. Forty-two were farmers or graziers, with the remainder in essentially unskilled occupations, and of ninety-eight stated religions, nineteen were Roman Catholic and the rest Protestant. With odd exceptions the men were country born and Australian born. ${ }^{10}$ Neither the occupations of the men nor the addresses of their next-of-kin indicate whether they were country men or country town men, but when we consider that few town men in unskilled occupations would have been able to afford the upkeep of a stabled horse, it can be reasonably concluded that the majority of the mounted infantry unit came from the bush.

On the word of their commanding officer, the thirty Australian Horse members included in the unit were certainly bushmen. Lieut.-Colonel K. Mackay, M.L.C., described his regiment, which he had founded as recently

\footnotetext{
8 Daily Telegraph, 21 October 1899, p. 5.

9 ibid, 25 October 1899, p. 5.

10 J.M. Antill, "Record of N.S.W. Mounted Rifles", Macarthur Papers, M.I. Preference in recruiting was for single men over 20.
} 
as 1898, as "purely a bush organisation, the men being either shearers, station hands, farmers, or squatters, and the officers in nearly all cases, sons of old squatting families". ${ }^{1}$ The Australian Horse was a cavalry regiment with a strength of about 400 men, drawn principally from Goulburn, Quirindi, Mudgee, Scone, Gunnedah, Bungendore, Murrumburrah, Braidwood, Cootamundra, Gundagai, Michelago and Rylstone. ${ }^{12}$ As a volunteer force its members were distinguished from militia men mainly by receiving no pay for attendance at parades and very little government assistance of any other description. The men were accomplished as horsemen but not as soldiers. ${ }^{13}$ The only other cavalry unit in the Australian colonies was the New South Wales Lancer regiment. ${ }^{14}$ It had eight half-squadrons located at Sydney, Parramatta, Berry, Robertson, Maitland, Singleton, Lismore and Casino; but forty men of the squadron sent to Aldershot were from the Sydney and Parramatta units. ${ }^{15}$ No particular mode of selection had been applied to the Aldershot detachment, the first 103 men to come forward with twenty pounds towards the cost of the trip being selected. One report stated that the majority of the Aldershot Lancers were married or had dependent relatives. ${ }^{16}$ The average age of members of the detachment was

11 Correspondence of New South Wales Governor with Colonial Office, C.0. 201/625, A.N.L., Lieut.-Colone1 K. Mackay to Ear1 Beauchamp, 18 July 1899.

12 List of officers, Non-Commissioned Officers, and Men of New South Wales Military Contingents Serving in the Boer War - 1899, 1900, M.L.

13. Daily Telegraph, 1 November 1899 , p. 5 .

14 In military terms, cavalry were horsemen trained to fight mounted. Their weapons were the carbine (short rifle) and the sword or lance; and their main tactic was the charge. Mounted infantry were soldiers who were trained to ride for reasons of mobility, but who did their fighting dismounted. The terms mounted infantry and mounted rifles were used indiscriminately in the Australian colonies, but British commanders came to apply the term mounted rifles exclusively to colonial irregulars.

15 Cox Papers, A.N.L., Lieut.-Colonel J. Burns to French, n.d.

16 Daily TeZegraph, 14 October 1899 , p. 9. The paper was promoting its "Lancer Insurance Fund" so it may have exaggerated. 
twenty-four and a half years; the average height was five feet nine and a half inches. Only seventy-two Aldershot men got off at the Cape, and a draft of forty men was sent from New South Wales to make up the squadron. ${ }^{17}$

The Army Medical Corps was to embark with a strength of ninetytwo men, including twenty-three permanent drivers of the R.A.A. ${ }^{18}$ This mixture of regulars and irregulars was drawn from the Sydney area. It made up in discipline, dedication and efficiency for what it lacked in the fruits of bush experience.

The infantry unit was drawn mainly from Sydney, the location of four militia battalions totalling 2,400 men. There were also 1,900 volunteer infantry men from which to recruit, the majority of these being centred in Sydney or Newcastle. ${ }^{19}$ Volunteering from this numerous branch of the service was not up to expectations, and a large proportion of those who did come forward were rejected on medical grounds. ${ }^{20}$

Officers for the New South Wales contingent were approved by cabinet on the recommendation of French. Competition for the few places ensured a good standard of officer. All were colonial men, a fact which Lyne found most pleasing. ${ }^{21}$

Recruitment of the Victorian contingent was characterised by a marked discrepancy between the numbers volunteering for service in the

17 ibid, 28 October 1899, p. 9. The only statistic available for the draft put the average age at twenty-eight.

18 ibid, 25 October 1899 , p. 5 and 28 October 1899, p. 10. The government had generally barred the colony's few permanent troops from joining the contingent, but an exception was made for the A.M.C.

19 Coghlan, Wealth and Progress of New South Wales, p. 209.

20 Daily Telegraph, 26 October 1899 , p. 5. Medical rejections were highest among the volunteer infantry, who did not undergo a medical test on entering the service. Medical standards were not high.

21 Argus, 21 October 1899, p. 14. Lyne's attitude reflected a wider opinion that colonial officers and men should have preference over Imperial men. Nationalism would have been a factor in this outlook but there was a desire to have the maximum possible number of colonial troops experience war conditions. 
event of war, and those who reported for attestation after Victoria had undertaken to send a contingent. New South Wales had experienced the same phenomenon, but with little effect on the raising of its contingent. In the southern colony the discrepancy made necessary the raising of infantry and mounted infantry units in part from sources other than those considered most appropriate.

The enrolment of Victorian volunteers for service in the Transvaal should war break out began on 20 September at Victoria Barracks. Members of all branches of the service were invited to register, as well as citizens with previous military training, ${ }^{22}$ and by 28 September 760 men of the defence forces and 280 civilians had volunteered. ${ }^{23}$ But after 3 October, when Victoria committed itself to sending 125 infantry and 125 mounted infantry, the call for recruits became more specific. By 12 October 260 mounted men from a volunteer regiment of 800 , and 250 infantry men from a militia regiment of 1900, had given in their names. This was hardly an enthusiastic response to the call to arms, but worse was to follow. When called up for medical and military efficiency tests, only 128 mounted infantry men and 107 infantry men reported. ${ }^{24}$ The medical examination also produced a surprise: forty percent of the applicants failed to pass a test considered not strict. The failure rate among the Victorian Mounted Rifles might be explained by the fact that as a volunteer regiment its recruits were not subject to any medical examination; but the same excuse could not be made for the militia, and their failure rate was just as high. ${ }^{25}$ To complete the numbers in both the mounted and unmounted units, the authorities called on the Victorian Rangers, a volunteer infantry regiment; but still lacking

\footnotetext{
22 ibid, 20 September 1899, p. 7.

23 ibid, 28 September 1899, p. 5.

24 ibid, 12 October, 1899, p. 5.

25 ibid.
} 
five men for the infantry unit they gave the places to members of the permanent artillery! ${ }^{26}$ Victoria had set out to enlist preferably single men of twenty to forty years of age, and it is a further measure of recruiting difficulties that twenty-seven married men embarked for South Africa. ${ }^{27}$

It was common for press reporters to regard the Victorian contingent as being composed of bushmen, but that could not have been so for about eighty percent of the infantry were recruited from Melbourne, with the remainder coming from Castlemaine, Ballarat, and Bendigo. Only the mounted unit was filled from country areas. A summary of the occupations of the Victorian contingent shows a preponderance of townmen, with rural areas being represented by landowners rather than rural workers. ${ }^{28}$

Selection of the officers for the contingent on grounds that ignored seniority was questioned in the Legislative Assembly, but defended by the premier who claimed that efficiency had been the criterion. ${ }^{29}$ An Age report regarded the officers, who had been selected from "numerous volunteers", as "young, intelligent and enthusiastic", 30 but when one considers the favourable connections of several of them, another factor in their selection seems likely. A biographical summary of the officers is given below. It indicates possible sources of influence, but more importantly, it gives an idea of the type of leader who sailed with the first and the second contingents. All the Victorians were colonials and in personal and professional details they appeared fairly typical of Australian militia officers of the time. ${ }^{31}$

26 Ago, 17 October 1899, p. 5.

27 ibid, 14 October 1899, p. 9 and 16 October 1899, p. 5.

28 Argus, 20 october 1899, p. 5.

29 V.P.D., 1899-1900, Vo1. 92, p. 1993.

3013 October 1899 , p. 5.

31 Argus, 19 October 1899, pp. 5-6. 


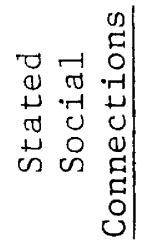

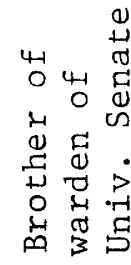

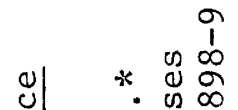

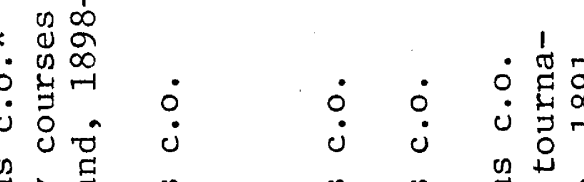

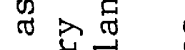

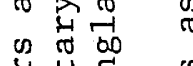

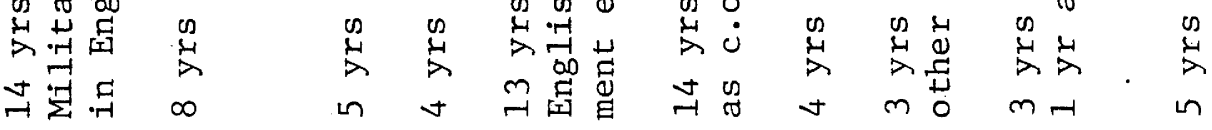

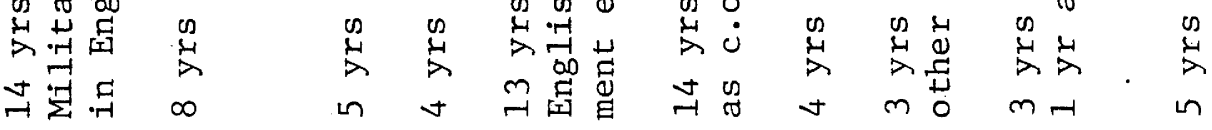

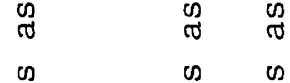

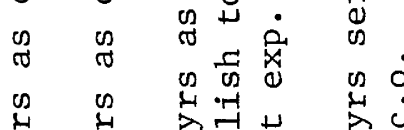

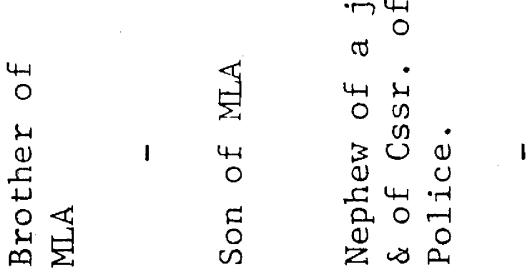

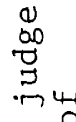

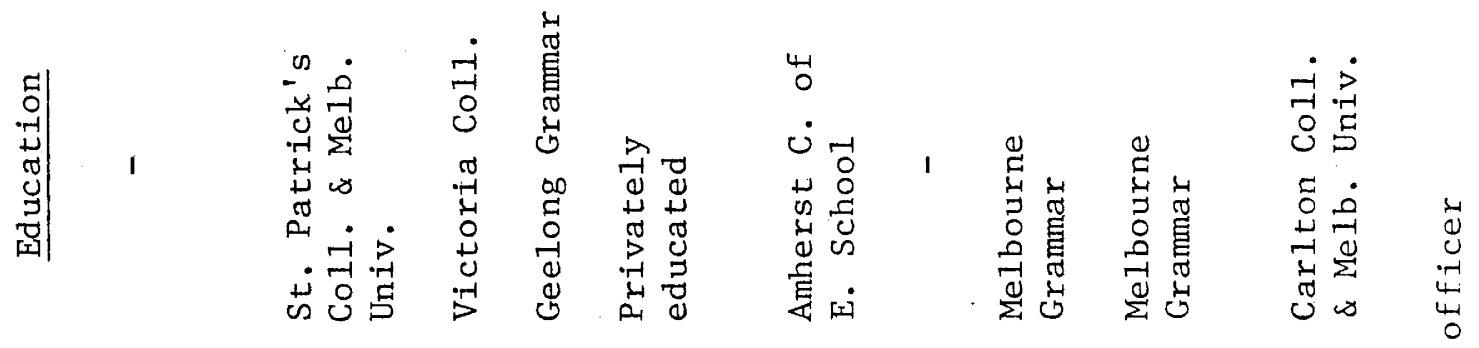

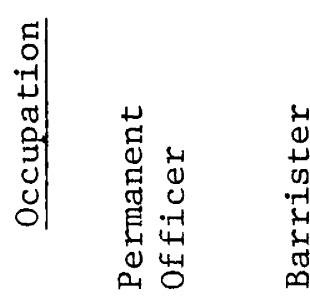

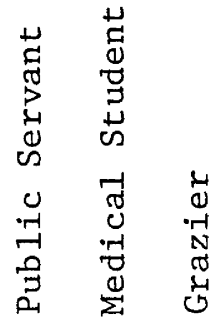

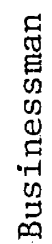

$$
\begin{aligned}
& \underset{\sigma}{\stackrel{\sigma}{Z}}
\end{aligned}
$$

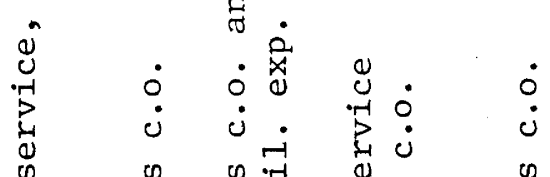

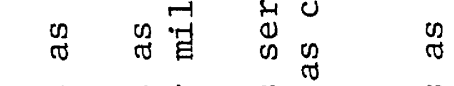

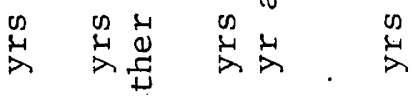

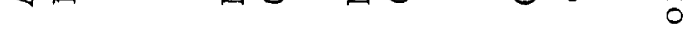

$$
\begin{aligned}
& \text { on } \text { के }
\end{aligned}
$$

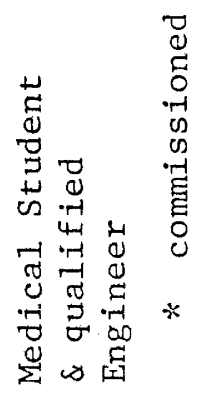

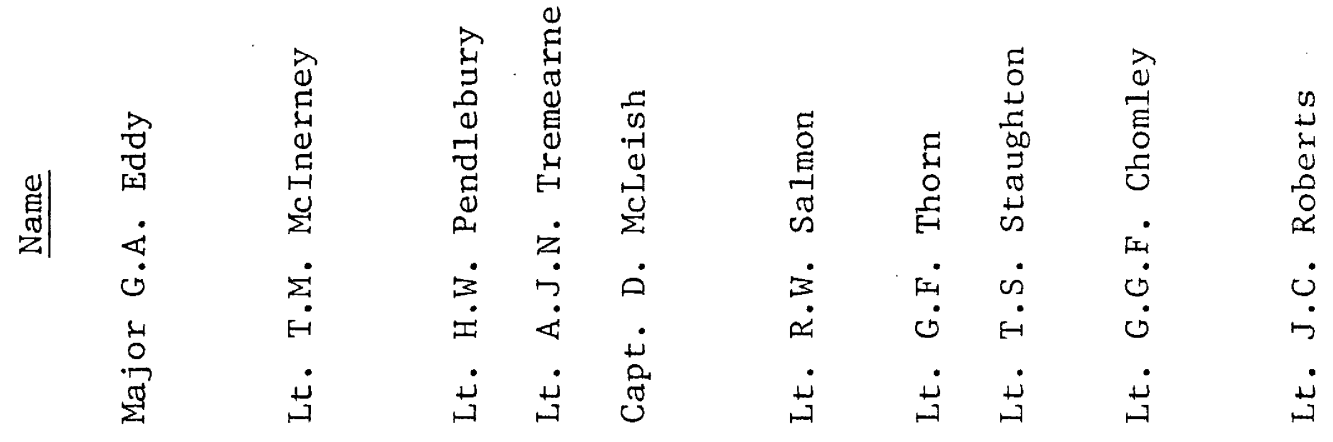


Queensland's problem was to produce the 250 mounted infantry promised to the Home government by the premier, J.R. Dickson, in July; not an easy task if press reports and parliamentary criticism can be considered informed. Although enrolments could not be finalised until the government gave its sanction to the contingent on 18 october, recruiting did proceed, the object reportedly being to raise twenty men out of the fifty who comprised each of the twelve half companies of mounted infantry. ${ }^{32}$ During the debate on the contingent, an opposition member claimed that the officer commanding the Queensland Mounted Infantry had reported to the military commandant on 27 September that he had sufficient volunteers, although press comment indicated that recruiting was going on as late as 17 October. ${ }^{33}$ Other members quoted alleged incidents which suggested pressure recruiting. Captain Harry Chauvel had enticed recruits from the Warwick half-company by assuring them the war would be "a grand picnic" with "very little risk" and no expense. ${ }^{34}$ Similar cajolery was used at Roma by Lieut.-Colonel Hutchinson, who promised a change from "the humdrum of ordinary everyday 1ife" at no greater risk than getting on a horse. ${ }^{35}$ On 10 October Colonel P. Ricardo addressed the Q.M.I. at Toowoomba and secured twelve volunteers. ${ }^{36}$ According to a member of the legislature, Ricardo's approach was to direct the paraded members thus: "Those who are willing to go to the Transvaal stand on the right of Sergeant McLennan and those who are going to stop and grow pumpkins stand in the ranks". ${ }^{37}$

32 Brisbane Worker, 16 September 1899 , p. 5. The Q.M.I. was a part-time force with an excellent attendance record for parades and camps.

33 Q.P.D., 1899, Vol. LXXXII, P. 440.

34 ibid, p. 776 .

35 ibid, p. 350 .

36 Brisbane Courier, 11 October 1899, p. 5.

37 Q.P.D., 1899, Vol. LXXXII, p. 460. The Brisbane Worker took up the cause of the "pumpkin grower" and by cartoon and comment set out to promote him as a symbol of humanity and goodness. 
If the recruitment of other ranks required effort, that of the officers did not. There was a scramble for places. The ramifications of that scramble can be inferred from a speech in the Assembly when a member interceded on behalf of four officers who had missed selection. The member complained that while an ex-Imperial officer had gained a place, two colonial officers with Hythe certificates, and another two who were regarded as intercolonial marksmen, were passed over. The member had made pressing requests to Colone1 Ricardo, the officer commanding the Q.M.I., on behalf of one of the men, and had followed this up by introducing the supplicant to the premier, who had personally recommended the officer to Ricardo. But still the man did not gain a place. ${ }^{38}$

Volunteering for South Australia's infantry unit of 125 men proceeded so slowly that a Sydney newspaper used the headline, "Apathetic South Australians", and noted that military authorities were considering the possibility of an active recruiting campaign. ${ }^{39}$ At that stage only about 150 men had volunteered and authorities estimated that one-third of these would be rejected medically. ${ }^{40}$ One call to a parade of 200 infantrymen in Adelaide had yielded twenty-five volunteers. ${ }^{41}$ On another occasion the roar of the elements proved stronger than the blasts of the bugles of war, for only twenty men out of a company of 100 turned up at a recruiting parade, "the smallness of the number being largely due to the wet night". Ten of the men gave in their names. ${ }^{42}$ Eventually 250 volunteers came forward but not all these were from the 1250-strong South Australian defence

38 ibid, p. 718.

39. Daily Telegraph, 13 October 1899, p. 6.

40 Age, 13 October 1899, p.5.

41 Daily Telegraph, 9 October 1899, p. 5.

42 Argus, 11 October 1899, p. 8. 
force, a number being civilians with some previous military experience. ${ }^{43}$

At the last moment the officer selected as the senior subaltern had to withdraw as he was detained by pressing private business. ${ }^{4}$

Tasmania's contingent of eighty infantrymen was drawn from 180 volunteers in a defence force of 1945.45 Western Australia's infantry unit of 125 was recruited without obvious difficulty, the only extraordinary thing being its composition. Fifteen were West Australians by birth, thirty were from Britain, and the rest were from the eastern colonies. ${ }^{46}$ Command was given to an Imperial officer, the commander of the Albany garrison artillery.

From existing sources, fragmentary though they may be at times, there emerges a reasonably clear picture of the men who were to lay the foundations of Australian military tradition. They were predominantly unmarried men, on an average in their mid-twenties. The average physique might have approximated a man five feet eight and a half inches in height, ten stone twelve pounds in weight, and thirty-five inches around the chest. ${ }^{47}$ This suggests a tallish, lithe soldier, and the suggestion is supported by numerous contemporary references to the Australians' admirable physique. If members of infantry units, the contingenters were most likely to have come from the cities; if members of mounted infantry and cavalry units they would have come mainly from country towns and rural areas. They would

43 Figures from South Australia Statistical Register, 1898 (Adelaide, 1899), Part 1, p. 18; Nominal Roll of South Australian First Contingent, A.W.M.; and A.P. Haydon, "South Australia's First War" in Historical Studies of Australia and New Zealand, Vo1. 11, No. 42, p. 227.

44 Argus, 11 October 1899 , p. 8.

45 ibid, 13 October 1899, p. 5.

46 Westerm Argus, 9 November 1899, p. 19.

47 These figures are based on statistics available for the Aldershot detachment of Lancers, and the 1st N.S.W.M.R.; and recruit averages for more than 1000 entrants into the part-time forces of N.S.W. in 1899-1900. For the recruit averages see N.S.W.V. \& P., 1900, Appendix No. 2 to Appendix C, Annual Report of N.S.W. Medical Services, p. 27. 
have had a liking for the military life, a modicum of discipline, but only a limited knowledge of the science of war.

How could they have been accomplished soldiers? As militia or volunteers, their periods of training were almost negligible. The Queensland militia were supposed to do eighty hours drill a year, but most of this would have been completed in an annual eight-day camp. The volunteer forces had to complete sixty-six hours of drill a year but attendance at camp was not compulsory. In South Australia, a minimum of thirty-six hours of training was required for the militia. Each member of Western Australia's volunteer force was required to attend twelve parades and fire forty rounds a year to qualify for an efficiency allowance of thirty shillings. These figures are representative of all Australian colonies. ${ }^{48}$

Drill occupied most of the limited parade time. There was some training in musketry but the weapons used were obsolete or obsolescent. The main Boer armament was a .276 calibre magazine Mauser. Against this the British were preparing to match their . 303 magazine Lee-Metford and LeeEnfield. ${ }^{49}$. In Australia at the outbreak of war the only unit equipped with the Lee-Metford was the New South Wales infantry militia. Elsewhere the single-loading . 303 Martini-Enfield had only recently taken over from the old .450 Martini-Henry. ${ }^{50}$

Shortcomings in the training of Australia's part-time soldiery were accentuated by the limited service of many members of the forces. The Aldershot detachment, we have seen, averaged only two and a half years service per man, and troopers of the recently formed Australian Horse would

${ }^{4} 8$ These statistics were gleaned from reports of military commandants, as published in parliamentary papers and colonial year books.

49 The only difference between the Lee-Metford and the Lee-Enfield was in the rifling.

50 South Australia still had the Martini-Henry. 
have had a maximum of one and a half years service. The brief period at the disposal of commanders before the first contingent sailed was not sufficient to rectify these deficiencies. There were drills and route marches and shooting practice, and Victoria even tried to simulate battlefield conditions by firing volleys in the midst of the mounted force, but the fact remains that the contingent went off to war ill-prepared. Its personnel were saved by the fighting style of their enemy, for they could not possibly have coped in a conventional war.

$$
* * * * * * *
$$

While the first contingent filled its ranks and sailed away to war, the three most articulate groups in colonial society raised their voices in defence of the expedition. From pressman, preacher and politician came utterances designed to mould an honourable cause for the soldier, and to denigrate his enemy in the field and his opponents at home. The way of the warrior was acclaimed.

An Argus reporter was so impressed at the sight of young Victorians embarking for war that he described the occasion as "an event worthy to signalise the closing of the century, and one which will not be forgotten when the century which follows is being put to bed". ${ }^{1}$ Another opinion looked beyond the present conflict, regarding it as a preparation by the military forces of Britain and her colonies "for the mighty struggle that a few brief years may witness". ${ }^{52}$ There were many similar accounts of the idealised function of the soldier, but the press was generally hesitant about praising the martial qualities of the untried Australians, though the Age made reference to "the flower of our manhood"53 and the Argus claimed

\footnotetext{
5127 October 1899 , p. 6.

52 Westerm Argus, 26 October 1899, p. 18.

536 November 1899 , p. 6.
} 
that in training, discipline and physique the men were comparable with the auxiliary forces of any country. ${ }^{54}$

The press was particularly severe on the enemy. In South Australia, the Register and the Observer set out to depict the Boers as a cruel and fanatical race. ${ }^{55}$ The Singleton Argus regarded them as an inferior people who must be brought down by the sword to "the humiliating position of serfs, dragged down because of their own tyrannical acts". ${ }^{5}$ The Manaro Mercury attributed the war to Boer "swagger" over the defeat of the British at Majuba. 57 The Western Argus regarded the enemy as "a somewhat brutal and very ignorant race". 58 The Age quoted "the eminent war correspondent", Villiers, on the Boers. He was said to consider them "some of the lowest types of humanity...unprogressive in every way", and prone to live "like pigs". 59 So widely propagated was this unsavoury and uncivilized image of the Boers that Australians must have initially accepted their soldiers as crusaders for a higher civilization.

Criticism of the contingent by Labour parliamentarians and others evoked from the conservative press responses that were often as intemperate as the attacks. Under the heading of "A Pro-Boer Councillor", the Age carried the story of a Ballarat town councillor who had remarked on the great disparity between the opposing forces and suggested that some Australian

54. 28 October 1899 , p. 12. The qualification is significant.

55 A.P. Haydon, "South Australia's First War", p. 226.

563 October 1899.

5716 October 1899, p. 2.

5826 October 1899 , p. 18

5919 October 1899 , p. 4. 
volunteers had gone to war for the sake of four shillings a day and not out of loyalty. ${ }^{60}$ In an editorial two days later the councillor was bitterly attacked. He had a "huckster's mind"; he was prepared to "sneer" at the men of the contingent; and he was willing to see the Boers, who "live like pigs....lording it over men of Australian birth". 61

On the other hand, the radical Catholic Press wrote disparagingly of the "valiant volunteers of the colonies", 62 and the Brisbane Worker strongly attacked the contingent. Following Dickson's offer of troops in July, the Worker had ridiculed the (non-existent) 250 mounted infantry men as "swashbucklers", but by late September it had to accept that there was volunteering from the ranks of the workers "either through necessity or through blind ignorance". ${ }^{63}$ The paper could not resist a final word to the departing troops, and in an open letter it asked how many had inquired into the right or wrong of the war. It also suggested that their views were derived from press falsehoods, and wanted to know if they would hand over their country to "a mob of Jew and foreign exploiters". Better to stay home and grow "the peaceful pumpkin". 64

Australia's ashamed of ye, living or dead, And the man of the pumpkin is honoured instead. ${ }^{65}$

The contingent went to war fortified by the blessing of the churches. The Anglican Synod in Victoria demonstrated "quite a warlike enthusiasm", and promised every facility to Church of England chaplains who might be called to the Transvaal to perform their duty "to God, their Queen, and

6017 October 1899 , p. 6. The rate of privates, as recommended by the commandants' conference, was $4 / 6$ a day, made up of the Imperial cavalry rate of $1 / 2$, and $3 / 4$ deferred pay met by the colonies.

61 p. 4.

6214 October 1899, p. 22.

6330 September 1899, p. 2 .

6428 October 1899, p. 2 .

6525 November 1899, p. 6 . 
their country". ${ }^{6}$ The Victorian Congregational Union offered up prayers for peace but if war should proceed "were equally fervent that the British nation, the upholder of righteousness, should triumph". ${ }^{7}$ The New South Wales Congregational Union showed a little more Christian apprehension over the conflict. At its annual session it expressed the hope that the war would bring an extension of popular liberty and the uplifting of native peoples, but it deleted from the original motion a clause expressing trust in the justice and humanity of British statemanship. ${ }^{68}$. The Moderator of the Presbyterian Church in Victoria admitted to ignorance of the factors involved in the war, but considered that he could trust in the wisdom of British statesmen. $^{69}$ A lesser figure of the same church regarded the war as "unnecessary and unrighteous", and for his pains was made the subject of an editorial attack in the Age. ${ }^{70}$ The Jewish faith in Australia expressed its loyalty through a prayer "appointed by the Chief Rabbi of the British Empire to be read in Synagogues every Sabbath during the continuance of the War". The prayer offered supplications "on behalf of the brave men, who pass through seas, armed for War in a far-off land, in obedience to the command of our beloved and venerated Queen and the bidding of her counsellors". 71

The Roman Catholic Church remained relatively aloof from the fervour of the October days. When the Church's acknowledged spokesman in Australia, Cardinal Moran, did speak it was to assert that true Australian patriotism was to stay home and defend one's own country. He felt that

\footnotetext{
66 Daily Telegraph, 29 September 1899, p. 5.

67 ibid, 13 October 1899, p. 6.

68 ibid, 28 October 1899, p. 8.

69 Age, 15 November 1899, p. 8.

70 ibid, 25 November 1899, p. 8.

71 A Prayer for Her Majesty's Forces in South Africa (Sydney, n.d.), leaflet, M.L.
} 
the troops had the colony's sympathy, however, because "they had received orders to go". 72

Individual churchmen, like their political brethren, seemed to regard the war as a grand opportunity to have their voices heard throughout the 1and. Bishop Green of Armidale described the enemy as a "brutal, obsolete, cruel and tyrannical oligarchy", but his attempts to join the contingent as a chaplain were confounded by the diocesan council of Grafton/Armidale, which was not convinced that his reasons for wanting to go outweighed his duty to his diocese. ${ }^{73}$ The rector of St. Luke's at Burwood regretted the war but recognised that in the present conflict England stood for justice and the integrity of the Empire. ${ }^{74}$ Archdeacon Gunther at Parramatta prefaced his views with the same sop to Christian pacifism and claimed that the war was a defensive one. ${ }^{75}$ At a public farewell to Bendigo volunteers, a cleric advised the men to "keep their sight clear and their powder dry, to turn. to God, and to fire straight". ${ }^{76}$ At a send-off in Newcastle to a part of the first contingent, the bishop of the city, in seconding the mayor's toast, said the men "had actually consecrated the streets of Newcastle by having trodden them with the feet of their loyalty and patriotism". ${ }^{77}$ The most ungodly statement came from a minor clergyman on a minor occasion, but such was the order of things that it received prominence in the press. At a farewell to a Swallow and Ariell employee in Melbourne, the Rev. E. James

\footnotetext{
72 AgC, 7 November 1899 , p. 5 .

73 Daily Telegraph, 17 October 1899, p. 5.

74 ibid, 17 October 1899, p. 5.

75 ibid.

76 Age, 23 October 1899 , p. 6.

77 Daily TeZegraph, 14 November 1899, p. 5.
} 
stated that Britain would not tolerate injustice and oppression and "he asked in all sincerity that God would speed the bullet for the liberty of the world". 78

Despite their general support for the war, the churches did not figure prominently in the official farewells to the contingent. There was no religious service associated with the march through Melbourne streets. In Sydney there was a valedictory religious service at Victoria Barracks before the farewe11 march began, but Cardinal Moran was not pleased at what he called "the ridiculous Protestant service" which Catholics were obliged to attend. ${ }^{79}$ The spiritual needs of the soldiers were better served in Adelaide where an "immense crowd" attended a public church parade at the Jubilee Exhibition Building. Great enthusiasm prevailed throughout the service and at the conclusion of the sermon the gathering rose as one and sang the anthem and cheered wildly. ${ }^{80}$

The mixture of sacred and profane was to become commonplace in the weeks and months ahead, but one of the most glaring examples of religious impropriety occurred at the annual diocesan festival of the Church of England at Ballarat. The governor, Lord Brassey, was there, revelling in the victories of the British army; Trooper Cherry sang Rule Britannia; a brace of bishops expressed their thanks to God for British military successes; and the Bishop of Ballarat called for cheers for the Empire and the Queen, during which Lord Brassey vigorously waved a miniature red ensign in vice-regal glee. 81

No provision had been made to send a chaplain with the contingent. This led to numerous protests by the churches to the relevant authorities in several colonies. In New South Wales, a deputation of Anglican, Wesleyan

\footnotetext{
78 Argus, 23 October 1899, p. 6.

79 Age, 7 November 1899 , p. 5. Moran added that W.B. Dalley had done better than that in 1885 .

80. Daily Telegraph, 30 October 1899, p. 7.

81 Age, 26 October 1899, p. 5 .
} 
and Presbyterian churchmen waited on the minister for defence, and he and Major-General French permitted an Anglican clergyman to accompany the contingent. ${ }^{82}$

The Queen's representatives in Australia were to play a significant part in events connected with the departure of the colonial contingents. Most prominent was Lord Brassey, who seemed bent on justifying Britain's intervention in the Transvaal. The Victorian governor, great proponent of the concept of an imperial naval reserve drawn from the colonies, must have been delighted to witness a situation that gave credibility to his scheme. "If the Empire were really in danger these colonials would make great efforts", he confided to Chamberlain. ${ }^{83}$ But while he acclaimed the potential of the colonial soldier, he usually saved the greater praise for the British regular. In his farewell speech to the troops, Brassey assured them that they were "worthy to stand shoulder to shoulder with that band of heroes" already fighting in South Africa. ${ }^{84}$ And he repeated the sentiments when he stood with Lord Beauchamp during a Melbourne farewell to a part of the New South Wales contingent. ${ }^{85}$

If Brassey privately considered the Empire to be in no danger, it was understandable that he should show a preoccupation with publicly justifying British belligerency. In a lengthy speech at the Grand National Show at Maryborough, his main theme was the justice of the British cause, ${ }^{86}$ and he dwelt on the issue again at a mayoral banquet in Melbourne. ${ }^{87}$

\footnotetext{
82 Daily Telegraph, 27 October 1899, p. 5.

83 Correspondence of Victorian Governor with Colonial office, C.0. 309/148 A.N.L., letter of 18 October 1899.

84 Age, 30 October 1899, p. 5.

85 Argus, 9 November 1899, p. 5.

86 Age, 20 October 1899 , p. 5.

87 Argus, 10 November 1899 , p. 4.
} 
Beauchamp was not nearly as active as Brassey, but his perceptiveness led him to take a course of action which probably had more effect on Australian loyalty than anything the Victorian governor said or did. On 24 October he telegraphed the Colonial Office:

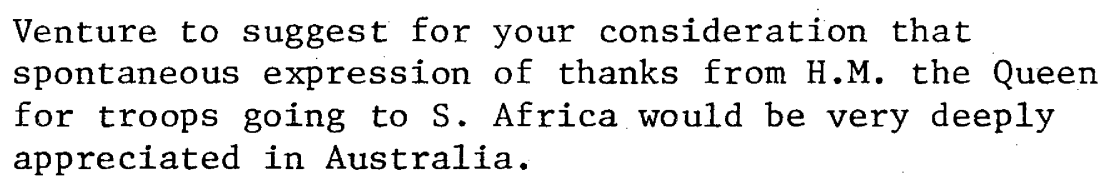

Chamberlain acted quickly. A draft telegram was sent to the Queen at Balmoral for approval, and a cable of thanks was on its way to the colonies at 3.30 p.m. on the day of Beauchamp's request. ${ }^{88}$. The Australian press did the rest, and Australians revelled in their monarch's gratitude.

In South Australia, Lord Tennyson also played an active imperial role. He addressed the colony's troops as "Men of the South Australian Contingent of the British army in South Africa", and applauded their "alacrity in obeying the summons of the old country". He had a lot to say about the importance of discipline, but he considered that the men would prove competent soldiers after a little military experience. ${ }^{89}$ During their brief training period Tennyson visited the troops in camp several times. He had the entire contingent to lunch at Government House and then capped a fine vice-regal performance by marching with Lady Tennyson at the head of the contingent to the docks.

Their profound deliberations in the colonial legislatures completed, politicians turned to enjoy the fruits of their labours. It was a time to bathe in the reflected glory of the departing troops. It was a time to appear on platforms at farewells to individual soldiers, and to take part

88 Correspondence of New South Wales Governor with Colonial Office, C.0. 201/625, A.N.L.

89 Creswicke, South Africa and the Transwaal War, Vol. 3, p. 154. 
in the embarkation parades in the capital cities. William Lyne, despite his apprehensions that the Victorian contingent might be first to the Cape, enjoyed himself immensely. He took part in the valedictory religious service at Victoria Barracks; he spoke with patriotic fervour at a luncheon given to 500 prominent citizens by the owners of the troopship, Kent; he formed part of the great march through the streets; and he followed the troopship up the harbour in a launch adequately equipped for the convivial hour. ${ }^{90}$ At a Patriotic Fund meeting in the Town Hall a few days later, he was so carried away that he promised another contingent of 10,000 men. ${ }^{91}$

Many politicians had surrendered principle to expediency in matters relating to the war, but Sir George Dibbs represented the prime case of hypocrisy and opportunism. In 1893, when Dibbs was premier and Colonel E.T.H. Hutton had just been appointed colonial commandant, the former had cut the military estimates by $£ 30,000$, the sum needed to run the essential Easter encampment. In a press interview Dibbs described the camp as a luxury and spoke of putting Hutton in his place, that is, subordinate to parliament. 92 Yet at both departure parades for the New South Wales contingent, Dibbs marched proudly at the head of the scarlet-coated National Guard, a small body of rather ancient reservists who could hardly be reckoned part of the military establishment.

One New South Wales politician who was prepared to ignore the heroics of the occasion was P. Crick, the Postmaster-General. He refused military leave to married men for service in South Africa, on the grounds that there was another duty besides loyalty to Empire and that was loyalty to a man's wife and family. ${ }^{93}$

90 A steamer carried other M.P.'s and their wives. On board toasts were drunk to Colonial Secretary See who as seriously designated "the Minister for War". - Daily TeZegraph, 30 October 1899, p. 6.

91 Daily TeZegraph, 3 November 1899, p. 5.

92 Hutton Press Cuttings, Vo1. 9, pp. 90-1, from Hutton Papers, A.N.L. 93. Daily Telegraph, 25 October 1899, p. 6. 
In Victoria, parliamentarians joined in the novel entertainment surrounding the dispatch of a contingent. Thirty of them, accompanied by a hundred friends, visited Flemington showground to watch the V.M.R. unit carry out battle exercises. ${ }^{94}$ A reception in their home town for the seven Bendigo members of the contingent attracted, among other people, two M.L.C.'s and three M.L.A.'s. ${ }^{95}$

Parliamentary patronage of the Melbourne farewe1l, self-indulgent though it might have been, was a further assurance to the troops that they were part of an extraordinary happening. Members and their wives watched the parade from a vantage point at Parliament House, whence they were taken by cabs to the docks to board the Monowai. The vessel had been made available by the Union Steamship Company, and M.P.'s had "a merry meeting in the saloon" at the expense of the company while following the Medic to the heads. ${ }^{96}$

The occasion of the mayor's farewell to the contingent lifted Sir George Turner quite out of his usual character. It was reported that "no one would have recognised in the fiery orator of last night the cold arithmetician of the Government". The premier was greeted with cheers when he assured the volunteers that they would not be "mere hewers of wood and drawers of water" (a possibility suggested by Labour speakers during the debates). ${ }^{97}$

The Victorians received further assurances when they reached Adelaide. C.C. Kingston, the South Australian premier, at a civic reception to Victorians and Tasmanians aboard the Medic, told the men that "they went to fight for Queen and country, and constitutional freedom from a serfdom

\footnotetext{
94 Argits, 27 October 1899 , p. 5.

95 Agc, 23 October 1899, p. 6.

96 V.I.D., 1899-1900, Vo1. 92, pp. 2240-2.

97 Argus, 28 October 1899, p. 13.
} 
worse than death". Andas proof of the justice of the cause he offered the fact that Lord Rosebery supported Lord Salisbury. ${ }^{98}$

Later the Bulzetin was to regret that politicians had not seized the opportunity to stand against the tide of ignoble militarism; the Hour had not found the Man. ${ }^{99}$ Few, indeed, had stood with any resolution against involvement during the October debates. Who would stand against war now, when all articulate agencies had accepted the cause as just and the volunteers as patriotic and romantic figures? The politicians had acted throughout with little regard for the higher values of young Australian nationalism. Instead, in accepting militarism and imperialism, they were accepting 01d World values that they had generally regarded as alien to Australian democracy. The Bulletin could be excused for bemoaning the fact.

We had a dream - it seems but yesterday That dream is dashed - to direst darkness hurled; For where our Commonwealth - a virgin 1ay, A Wanton fronts the wor $1 \mathrm{~d} . . .100$

The men of the first contingent had been told by press editors, parliamentarians and other public figures that what they were doing was right. But only when the hitherto inarticulate masses expressed their approval at public concerts and during farewell parades did the volunteers realise their new importance. Soldiers' letters and diaries frequently testified to the exhilirating effect of the roar of the crowd. But not only were the departing troops affected by the tumult of the crowd. It also inspired others, citizen and militiaman, to emulate the action of the volunteers. As an observant trooper put it: "The streets were full of

98 James H. Birch, Jr., History of the War in South Africa (Toronto, n.d.) p. 11

99 Buzletin, 25 November 1899, p. 6.

10023 December 1899, p. 7. 
citizen soldiery, and still more full of civilians burning with the zeal which creates citizen soldiery". 101

If the crowds were a motivating force in later enlistments, what motivated the crowds? Nationalism and a desire to identify with the greatest power in the world were paramount factors. The Times History regarded the enthusiasm as a manifestation of national rather than Imperial sentiment, with national self-consciousness being stirred by the sight of troops to whom their country's credit was entrusted. Imperial sentiment and love of the mother country were there too, "but as the emotional setting ... to the no less intensive national feeling". ${ }^{102}$ That same observant trooper saw the wild enthusiasm of the farewell as

the manifestations of a people mad with the excitement of their first taste of war, the first shedding of blood in which they had an interest of their own... What Australians for the most part wished, was that England should recognise her willingness to share the burdens of Empire as fully as its advantages, and this thrill of emotion - war fever, jingoism, national insanity, or whatever it be called - was merely the inarticulate expression of the delight with which the acceptation of their proffered aid filled the colonies. ${ }^{103}$

The Argus explained: "We are proud of our racial kinship and heritage. Our interests are bound up with Britain's high place among the powers and the integrity of her empire". ${ }^{104}$ The Sydney Daily Telegraph interpreted public enthusiasm for the war as proof that the people wished to become "working partners, for better or for worse, in the foreign policy of the British Empire". 105

\footnotetext{
101 Abbott, Plain and Veldt, p. 19.

102 Vo1. 3, p. 27.

103 Abbot, Plain and Velat, pp. 29-30.

1041 January 1900 , p. 4.

10530 October 1899 , p. 4.
} 
$\Lambda$ modern scholar, Donald C. Gordon, has also emphasised the growing-up process:

It was national sentiment in Canada and Australia which demanded that they share in the dangers of empire as well as the benefits they had long known. Self-appreciation would no longer permit colonial peoples in such advanced areas to feel that they could make no significant contribution to the war in which Britain was engaged. ${ }^{106}$

Troop farewells invariably began at the local level. Quite of ten they were civic affairs, for aldermen and councillors were as keen as politicians to appear on platforms with the men of the moment. The pattern of activities was common. The volunteer was honoured at a suitable function (frequently a smoke concert for males only), where he was the subject of speeches and a presentation. Later there was a parade through the streets, ending at the local railway station or coach depot. From there the hero departed to war amid cheers, martial music and singing, and the songs they sang were: The Girl I Left behind Me, When Johnny Comes Marching Home, Auld Lang Syne, The Minstrel Boy, Rule Britannia, Sons of the Sea, and above all, Soldiers of the Queen.

Less intimate but no less flattering to the volunteers were the great farewell parades at the points of embarkation. The functions were assured of maximum popular support by the actions of the civil and military authorities, who either scheduled the parades for non-working days or proclaimed special holidays. The Queensland and Victorian contingents paraded on Saturday afternoon. The New South Wales contingent sailed in three sectionswhich embarked on different days. Those leaving on the Kent marched through Sydney streets on Saturday afternoon. Those embarking on the Aberdeen marched through Sydney on Friday, though every effort had been made to delay

106 Donald C. Gordon, The Dominion Partnership in Imperial Defense 1870-1914 (Baltimore, 1965), p. 152. 
the departure of the vessel to permit a Saturday farewe11. A half-holiday was granted to government employees for the occasion. A public holiday was declared for Newcastle and the Hunter River district when the third New South Wales section left from the northern city. A public holiday was planned for Adelaide, but it did not eventuate because it was not known precisely when the Medic would berth to take aboard the South Australian contingent.

The Victorian government took additional steps to ensure the success of the Melbourne farewell by making available holiday excursion fares from all stations to the city. It also approved the issue of free rail passes to the immediate relatives of country members of the contingent. ${ }^{107}$

In Sydney, the rain was heavy and continuous when the men embarking on the Kent marched through the streets on Saturday 28 0ctober. But that did not quell the ardour of a crowd estimated at between 250,000 and 300,000 and thought to be larger than that which farewelled the Soudan contingent. There were no distinguishing badges on the uniforms of the contingenters, so the escorting militia units were cheered as well. There was an embarrassing delay to the military procession as the troops swung down Park Street and across Elizabeth Street for no-one had thought to stop the trams. From two o'clock until dark the excited populace cheered in the streets and at the docks and many retained their enthusiasm until well into the night. One reporter said of the march: "It will surprise the mother country; it has even surprised ourselves! We knew we were loyal, but it required a stirring episode to provide such convincing proof". 108

107 V.P.D., 1899-1900, Vo1. 92, pp. 1919, 1993. The relatives' passes were intended also as mementoes. They set out "with picturesque effect the unity of the empire and Australian devotion to the mother country". Argus, 29 October 1899, p. 5.

108 Daily Telegraph, 30 October 1899, p. 5. 
Light rain fell on Friday 3 November when the Aberdeen troops marched through Sydney. The crowd was smaller but there was a greater show of bunting, including a banner across the intersection of Park and Pitt Streets which reflected the growing confidence of the public in their fighting representatives:

Be copy now to men of grosser blood, And teach them how to war. (Henry V). ${ }^{109}$

The Newcastle demonstration was of a magnitude befitting a proclaimed holiday, but its conclusion was marred by an element of farce. The Langton Grange was not ready to receive the troops, so to conclude the great military display suitably at the docks the men went aboard a smaller steamer, not for foreign fields but for a trip around the harbour. Later they quietly disembarked and spent the night in a drill hall. 110

The Victorian contingent was given a taste of the morrow by the crowds who thronged inside and outside the Melbourne Town Hall for the mayor's farewe11. "For the first time in the history of Victoria the thrill of patriotism vibrated through the nerves of the people", and their hearts were stirred by the colony's first plunge into "the great deeps of international warfare". After the ceremony, the troops headed a triumphal procession back to barracks, and as the men disappeared within the gates the huge crowd sang Soldiers of the Queen. 111

The thronged streets were lined by 2000 school cadets for the march the following day, Saturday 28 October, and the contingent had an escort of 4000 members of the defence forces. Included in the column, and basking in a glory they must have thought gone forever, were former Imperial soldiers, "ambling but proud old wrecks" who wore the medals of Crimea

\footnotetext{
109 ibid, 4 November 1899 , p. 9.

110 ibid, 14 November 1899, p. 5.

111 Argus, 28 October 1899, p. 13.
} 
and the Mutiny. ${ }^{112}$ Lieutenant Tremearne, in writing of the occasion later, told of people, perfect strangers to him, rushing into the ranks with tearfilled eyes and murmuring, "Good luck, old man". ${ }^{13}$ Followed by a flotilla of smaller craft, the Medic, largest ship ever to enter an Australian port, sailed down the bay and turned to the open sea. Long after the cheering had died and the launches had turned back, Victoria continued to salute her first contingent with huge bonfires which blazed along miles of coastline. ${ }^{114}$ Other cities had farewell ceremonies just as spontaneous as those of Sydney and Melbourne, and before mid-November all troops for South Africa were on the high seas. The Medic carried the units from Victoria, Tasmania, South Australia and Western Australia. The men from New South Wales were aboard three ships, and the Queenslanders, possibly both by choice and out of necessity, were still going it alone.

$$
* * * * * * *
$$

The Australian people had acted creditably enough during the first weeks of war. They had revealed elements of national immaturity in their behaviour, but nothing malicious. When the incident of the New South Wales Lancers occurred, however, a deplorable aspect of the Australian character was demonstrated.

Throughout the greater part of 1899 , a squadron of Lancers had been training with regular British cavalry regiments at Aldershot. The officer commanding the detachment, Captain C.F.Cox, offered the entire squadron for service in South Africa when war seem likely and the offer was accepted. But when the Lancers reached Cape Town in a ship bound for

112 Age, 30 October 1899, p. 13.

113 A.J.N. Tremearne, Some Austral-African Notes and Anecdotes (London, 1913), pp. 5-6.

114 ibid, p. 8 . 
Australia, only 72 out of 101 men disembarked. The remainder went on to Australia.

The reaction was profound. The returning men were reviled in the streets and in parliament, and were forsaken by their regimental commanders. The unfortunate affair can be understood, if it cannot be condoned. The decision of the twenty-nine Lancers not to disembark for active service came at a time when the Australian colonies were flushed with self-esteem. England had accepted their offers of troops, and the men of the first contingent had received sufficient praise from notable people to make the colonists optimistic about their performance in South Africa. Much of this pride and expectation was threatened, however, by what Britain and the rest of the Empire might construe as cowardice or lack of loyalty.

An examination of the whole episode indicates that the handful of Lancers were neither cowards nor disloyalists, but were victims of the extraordinary times. Much of the bitterness directed at the returning Lancers rested on a belief that they had volunteered for active service, and then changed their minds before the eyes of the Empire. The issue was not so clear-cut, and a Daily Telegraph reporter who accompanied the Lancer squadron from London in the Nineveh gave a comprehensive account which raises doubts about the extent of volunteering among the detachment. Captain Cox explained to him that early in June he had been approached by "the men", who said they were anxious to go to the Cape. Cox called the Lancers together and asked if this were so. Only one man demurred. Cox passed on the outcome of the meeting to Lord Carrington, honorary colonel-in-chief of the Lancer regiment, and Colonel Burns, the officer commanding the regiment. When war was imminent, Cox spoke again with Carrington who notified the New South Wales government of the desire of the squadron to serve in South Africa. Cox had seen no necessity to consult the men again before his approach to Carrington, but on 7 October the War Office consulted them by ballot. According to 
information that the reporter received, "over 30 men" declined to volunteer. ${ }^{115}$ War Office action was obviously justified. But Cox, Carrington, and the New South Wales Agent-General, Sir Julian Salomans, continued to play the part of the three wise monkeys.

On 10 October, London gave the Lancers a wildly enthusiastic farewe11. The streets were so crowded that all traffic was suspended along the route of the march. Amid this fervour, which would have swelled the pride of any colonial agent-general, Sir Julian vehemently denied a Daily Chronicle report that twenty-six Lancers had refused to volunteer. The statement was false, he said, and the entire squadron was burning with impatience to get to the front. ${ }^{116}$ Meanwhile the War office had made known its displeasure. Cox was called before the Aldershot authorities the night before the Lancers embarked, and shown a War Office letter expressing Lord Wolseley's indignation over Cox's having stated that all the men would volunteer. ${ }^{117}$ The ire of the Commander-in-Chief was understandable, for since its offer to serve in South Africa the squadron has been hailed by the English press as a symbol of Imperial solidarity. No official statement was made on the Lancers, and some authorities hoped that the dissenting troopers would change their minds by the time the Nineveh reached Cape Town. ${ }^{118}$

The dissenters, however, had good reasons for not changing their minds. Many claimed that they were not present when Cox made the inquiry in June. This would have been true, for twenty-five were taking part in a Dublin tournament at the time, and many more were sick with measles and colds. ${ }^{19}$ Others were in financial straits, some had been granted only

\footnotetext{
115 Daily TeZegraph, 25 November 1899, pp. 9-10.

116 Age, 12 October 1899 , p. 5.

117 Daily Telegraph, 25 November 1899, p. 10.

118 ibid, p. 9.

119 Cox Papers, A.N.L., letter from Cox to Burns, n.d.
} 
limited leave by their employers, while others were in poor health.

The news that twenty-nine Lancers had failed to remain with their squadron had startling effects in New South Wales. In Parramatta, one father announced that he would make his son return to South Africa immediately; and a mother said that if her son had returned she would have been at Circular Quay to shoot him. ${ }^{120}$ The residents of Berry expressed great relief that ten of the town's Lancers had remained to fight, and only one man, who was ill, had returned. ${ }^{121}$ Singleton waited anxiously for an official explanation why two medically fit men from the town's half-squadron had returned. ${ }^{122}$ In the city that housed the headquarters staff of the New South Wales Lancers, "self-possessed businessmen fumed over the slur cast upon Parramatta particularly", and in Parramatta streets small boys called out derisively whenever a Lancer uniform was seen. At nearby Carlingford, a schoolteacher was reported (wrongly) as returning home to a class that planned to stay away from school for two weeks as a protest. ${ }^{123}$ And in addition, the returning men received white feathers and abusive letters. ${ }^{124}$

New South Wales parliamentarians showed extreme embarrassment over the affair during question time in the Legislative Assembly. R. Sleath attacked the Lancers as men who had strutted around Sydney in their flash uniforms, got themselves off to England on a picnic, and then failed when put to a trial. "They have, practically, brought disgrace upon the colony, and I am perfectly satisfied the people are disgusted with their action". ${ }^{25}$ The member for West Maitland feared that if a Lancer from his district, who

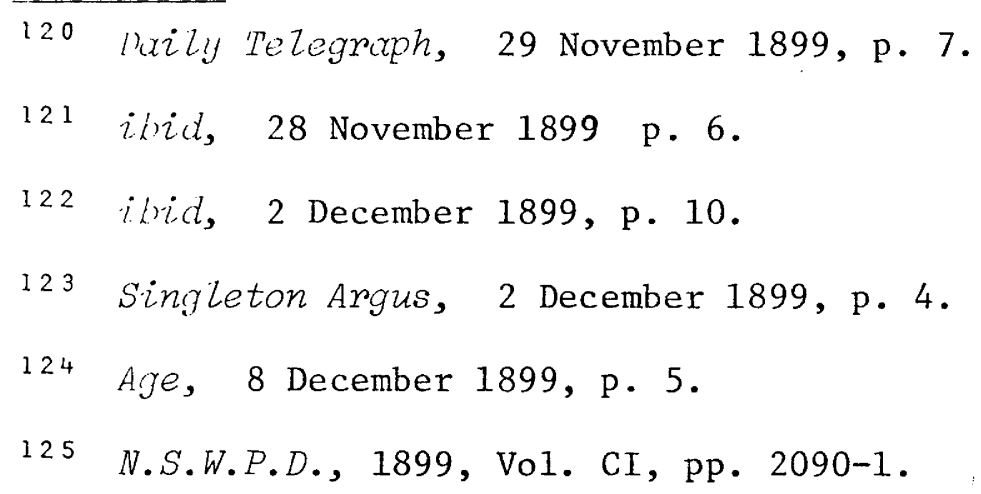


"should have gone" to war, returned to the area he would be tarred and feathered. He regretted that the action of a few should have spoiled the great pride New South Wales experienced when the Lancers volunteered and were treated so magnificently in London as representatives of the colony. 126 J. Cook felt that the affair had placed "a big and deep stain on the escutcheon of the colony", for the men had passed right by the conflict but were not prepared to lend a hand. ${ }^{127}$ A few members suggested that judgement should be suspended until each case was treated on its merits, but none took up the cause of the maligned men.

Following a military inquiry into the matter, Major-General French reported that of the twenty-nine Lancers who had come home, nine were medically unfit for active service, eight were minors who had been ordered back from the Cape by their parents, and five had given satisfactory reasons for returning. He said nothing about the remaining seven. French considered that the men had no responsibility to volunteer but regretted that they had not. Colonel Burns passed judgement by observing, "We have 72 heroes out of 92 men". ${ }^{128}$ So great was the odium attaching to the returned Lancers that all of the seven whose reasons had apparently been regarded as unsatisfactory were reported to have volunteered for service in South Africa by mid-December. 129

Of these men, Corporal Ben Harkus emerged as something of a tragic figure. Harkus, a letter carrier on leave without pay, had taken his wife and two children with him to England, where he had been one of the most successful members of the detachment in tournament events. According to a

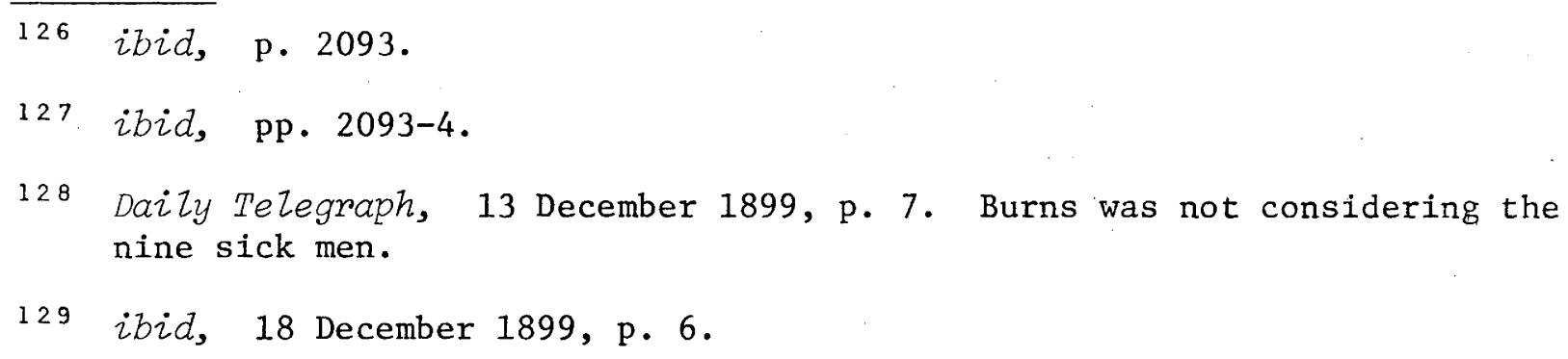


letter from Mrs. Harkus to the press, she had persuaded her husband to return home and put their business affairs in order before returning to the Cape. ${ }^{130}$ Three months after rejoining his regiment in South Africa, Harkus died of enteric fever at Bloemfontein.

If the public felt that he had made atonement, there was no evidence of their compassion in the press. Only the Bulletin saluted him, in a poem that had point and pathos. An anonymous poet recounted Harkus's return home for his family's sake, the jeering he suffered, the white feathers he received, and his return to South Africa so that his children would not be maligned. The poem concluded:

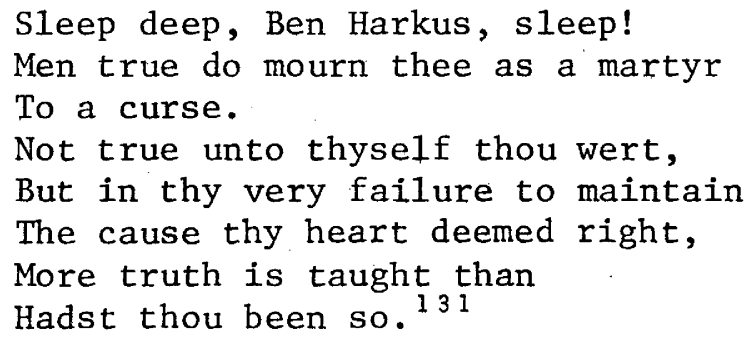

But Ben Harkus was not allowed to sleep in peace. Many years later his old commander, then Senator C.F. Cox, displayed the same insensitivity that characterised him during the South African War. Replying in parliament to criticism levelled at the Aldershot detachment by a retired British general, Cox wrongly described Harkus as the only returned Lancer who was not under age, medically unfit, or with adverse family circumstances, and then went on to say that "when he got back to New South Wales things were made so hot for him that he rejoined us in South Africa and died on service". 132

$$
* * * * * * *
$$

Even before the troopships bearing the first contingent had cleared

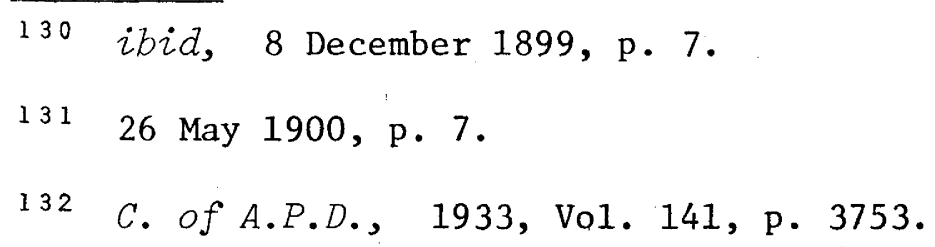


Australian waters, William Lyne took steps to send more troops to South Africa. The premier's motives must be suspect. At the time the advantage in the conflict appeared to rest with Britain, and if Australian participation was intended mainly as a gesture of loyalty that gesture had already been adequately made. Lyne had come under attack from George Reid for having been a follower rather than a leader among the colonies in the rush to arms, and his public statements throughout October had clearly shown that he wished to disprove such criticism. A successful initiative in raising a federal contingent would put his leadership beyond question, and might also please his Queen.

Lyne's move to organise an "Australasian contingent" in the first days of November began with a telegram to the other colonial premiers:

In view of complications which may arise, will you authorise me sending message to Secretary of State for the Colonies to the effect that if the British Government will accept, the colonies are prepared to send second contingent, of an equal number of men which might be called the "Australasian Contingent". 1 з

The response must have been disappointing to the New South Wales premier. Of the immediate replies, Victoria was prepared to send 250 men if needed, but Queensland though that nothing more should be done unless further complications arose, ${ }^{134}$ and South Australia declined to take part as it was felt that Australian loyalty had been sufficiently demonstrated. ${ }^{135}$

As it transpired, "complications" did arise which put a completely different complexion on the war. In the words of a noted British historian

133 Age, 6 November 1899 , p. 5. Lyne's action owed nothing to Sir Wilfrid Laurier's offer of a second Canadian contingent which was reported in the Argus of 10 November.

134 Argus, 6 November 1899, p. 5.

135 Ayge, 7 November 1899 , p. 5. 
of the conflict, the "week which extended from December 10 to December 17, 1899, was the blackest one known during our generation and the most disastrous to British arms during the century". ${ }^{136}$ The cause for gloom lay in three engagements. At Magersfontein, almost 1000 men were killed or wounded, most of them from proud Scottish regiments. At Stormberg, although fewer than 100 British soldiers were killed or wounded, over 600 were taken prisoner; a humiliating reverse. The final blow of "Black Week" was administered at Colenso, when Buller's force suffered 1200 casualties in a futile attempt to relieve Ladysmith. Amid the great wave of patriotic concern that swept the Empire, Lyne moved forward in another attempt to play his part as premier of the mother colony. But this time it was at the prompting of The Times.

Alarmed by the defeat at Magersfontein, The Times called for more troops, including more colonials, to reinforce the army in South Africa. ${ }^{137}$ Lyne immediately cabled the Imperial government concerning the article in The Times, and asked if additional troops were required from Australia. ${ }^{138}$ At the same time he sent telegrams to the other colonial premiers which read:

In light of latest war news, should British Government desire colonies send more troops, have. I your concurrence in offering an Australian contingent. ${ }^{139}$

The Colonial office acted quickly on Lyne's inquiry. The Home government would respond favourably to an offer of troops, and preference was to be given to mounted men who should "be trained and good shots". ${ }^{40}$ It was generally accepted that the reference was to members of the defence forces but a further cable from Chamberlain a few days later was taken as opening

\footnotetext{
136 Conan Doyle, The Great Boer War, p. 152.

137 Quoted in the Age, 15 December 1899, p. 5.

$138 \quad i b i d$.

139 ibid, 16 December 1899, p. 9.

140 ibia, 18 December 1899, p. 6.
} 
the second contingent to civilians. ${ }^{141}$ The switch of preference to mounted men was inevitable, for the British infantry had fared badly against a fully mounted foe. And to get those horsemen quickly the War office was prepared to enlist men with no previous military experience.

Parliamentary sanction for the second contingent was a formality. The colonial executives had responded quickly and favourably to Lyne's inquiry, and had proceeded with their planning, confidently assuming parliamentary endorsement. In the New South Wales Legislative Assembly, only W.A. Holman continued to oppose the war. ${ }^{142}$ On both sides of the House the sentiments were widely expressed that Australians were Britishers, that the Empire was in trouble and Australians were of the Empire, and that Australia could not expect help if she did not give help.

In the Queensland Assembly, debate was grave and subdued. A. Dawson, Labour leader and opponent of the first contingent, seconded the motion and dominated the short debate with his efforts to make his shift of ground credible. He spoke 'of Continental intrigue and hatred of Britain; he dwelt on the seriousness of British defeats; and he expressed concern at the extent of British naval preparations, which he felt could not be explained by a mere Boer threat. ${ }^{143}$

Debate in the Victorian Legislative Assembly was brief and uncompromising. Allan McLean, leader of a new ministry, drew attention to the changed military circumstances and the fact that the Empire was now engaged in a serious struggle. ${ }^{144}$ A common opinion among members was that the Empire

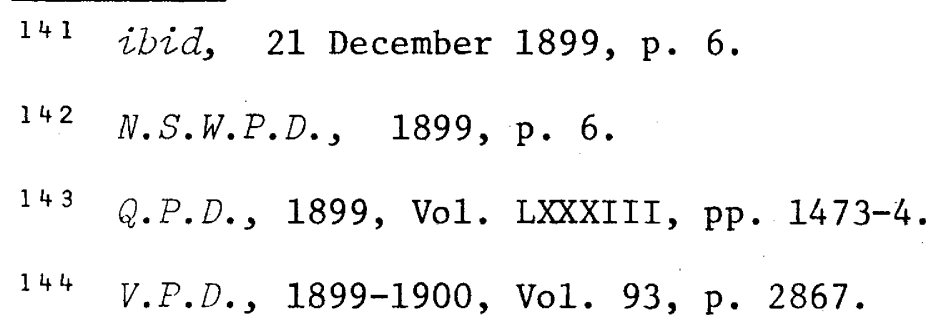


was at war and there was no room for debate. John Murray of the Labour party was greeted with the cry of "Traitor!" when he rose to say that he would not oppose the motion because it would be fruitless to do so. ${ }^{145}$ As a diversion he attacked W.A. Trenwith, the Labour leader, whom he described as "an Imperialist of the Imperialists" because of a patriotic speech delivered at the Town Hall. ${ }^{146}$ Trenwith lived up to the title when he moved (but later withdrew) an amendment seeking the employment of the contingent with Imperial forces anywhere in the world. 147

Thomas Price, Labour leader in the South Australian Assembly, supported the motion to send the contingent on the grounds that England and the Empire were in trouble. Price had stood strongly against sending the first contingent, but the only ire roused in this debate was directed against William Lyne. One member deplored the action of the New South Wales premier which "virtually pledged the whole of the colonies without first consulting the other Governments concerned". ${ }^{148}$ Thomas Playford was even more caustic, and possibly very close to the truth, when he denounced Lyne for having "tried to steal a march upon the other premiers" and for trying "to get the whole of the kudos for himself, following exactly in the steps of Mr. Dalley in connection with the Soudan". 149

The public recanting which took place in the colonial legislatures in December and January cannot be attributed solely to the stunning reverses of "Black Week". The defeats to British arms gave a depth and seriousness to war, placing it well beyond the popular idea of "a promenade to Pretoria",

\footnotetext{
145 ibid, p. 2865. Murray was later the subject of a most undemocratically conducted censure meeting at Warrnambool. - Age, 20 January 1900, p. 9.

146 ibid, p. 2870 .

147 ibid, p. 2880 .

148 S.A.P.D., 1899 , p. 1075.

149 ibid, p. 1077.
} 
but they could hardly affect the basic question of the tenability of the British cause. Previously dissenting politicians, however, so readily accepted the new military situation as justifying Australian involvement that one suspects they welcomed the opportunity to shift their ground to a position more in line with popular clamour.

$$
* * * * * * *
$$

William Lyne had taken the initiative in the matter of a second Australian contingent. In the weeks following, he sought to retain for New South Wales the lead he regarded as appropriate to the mother colony. But owing to his own tentative leadership, the rivalry between the two senior colonies, and British ignorance of or antipathy towards the idea, the New South Wales premier failed to organise a federal contingent.

Lyne and his cabinet established the contingent size at 1000 mounted infantry, plus "A" Battery of the Royal Australian Artillery, which had been offered to the Home authorities for the second time, and half a field hospital, which had been requested by Britain. ${ }^{150}$ It was tacitly accepted by the colonial premiers that representation in the mounted infantry force should be roughly on a population basis, with New South Wales making up any discrepancy in numbers. This arrangement promised numerical dominance of the contingent to the mother colony, for the artillery and medical units were both from New South Wales.

The premier was not so successful in taking transport details in hand, although he assured the press (and Lyne was eager to talk to the press about his plans) that his government would make all arrangements to embark the contingent. ${ }^{151}$ When he made an offer to Victoria along these lines,

\footnotetext{
150 Age, 20 December 1899 , p. 8 .

151 ibid, 19 December 1899, p. 6.
} 
however, McLean countered by asking why his colony could not make its own arrangements, seeing that the entire contingent could not go in one ship. 152 Without waiting for a reply, the Victorian premier went ahead with his own transport plan and notified Lyne accordingly. The New South Wales premier made a lame show of retaining control of the situation by telegraphing: "If you are offered suitable transport of men and horses, then you had better accept. Please let me know what you have done". 153

Lyne made an attempt to achieve uniformity of dress for the contingent. In a telegram to McLean he put forward the New South Wales mounted infantry uniform as a possible pattern, and asked if Victorians could be similarly attired. ${ }^{154}$ The Victorian reply noted that while the New South Wales uniform differed only slightly from that of Victoria, one important difference was that the Victorian uniform carried no tunic facings, a modification based on the experience of first contingent personnel who had removed all colour from their habiliments of war as a safety measure. It was suggested therefore, that New South Wales adapt her uniform to that of Victoria. ${ }^{155}$

No communication passed between the two colonies on the sensitive subject of the command of the proposed federal contingent, although both gave much thought to the matter. Victoria did not covet the command. In fact she appeared to concede it to the senior colony. There was strong support in Victorian military circles for the appointment of Colonel Tom Price as leader of the Victorian section of the contingent, but this was regarded as possible only if New South Wales appointed an officer of higher rank who

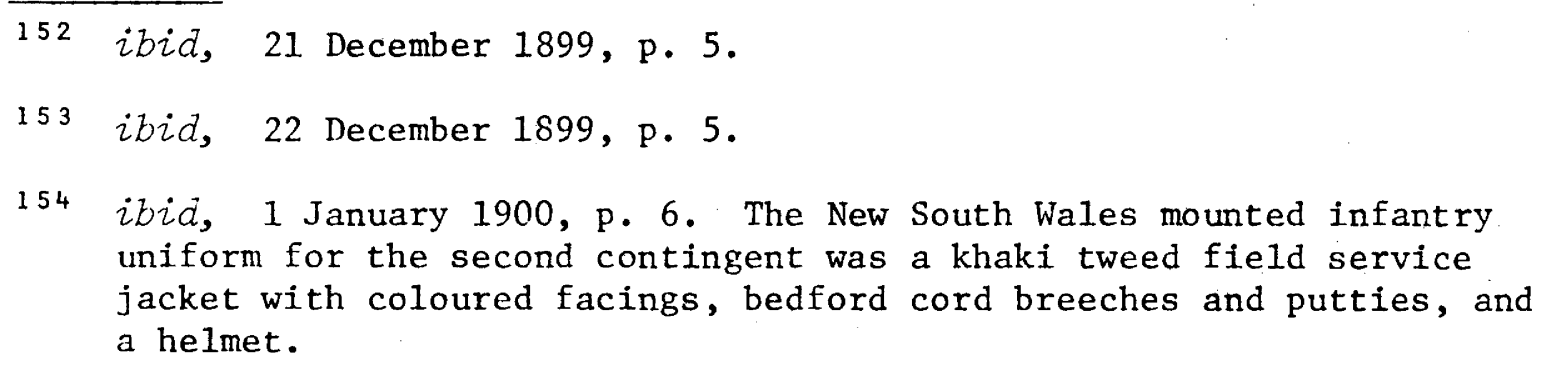
uniform for the second contingent was a khaki tweed field service jacket with coloured facings, bedford cord breeches and putties, and a helmet. 
could then command the entire Australian contingent. ${ }^{156}$ New South Wales proceeded on the assumption that the command was her right, and Lyne, with Major-General French in mind, cabled the Home government seeking permission for the military commandant to proceed to the front. But the request was refused. ${ }^{157}$ The War office had not specified a maximum rank for second contingent officers as it had done for the first Australian force, when it ruled that no officer above major could lead a colonial unit. But it would have had little desire to let loose in South Africa an ageing general with no war experience and without a command, and besides, the War office had decided there would be no Australian brigade to lead.

Faced with so many difficulties, the notion of a federal contingent soon lost momentum, and was brought to a halt finally by a Colonial office cable which asked that the Australian volunteers be organised into units of 125 men. ${ }^{158}$ The request was in line with war office conditions for the first contingent, but it is highly likely that Lyne influenced the decision, for the premier was playing an odd game. On the one hand he sought a federal contingent, initiated and organised by New South Wales and commanded by her senior military officer. On the other hand he sought to break up an Australian federal force which British authorities had assembled at Enslin in South Africa under the command of the senior Australian officer on the spot, a Victorian colonel. ${ }^{159}$ Lyne had acted on the reports of New South Wales officers who complained that they were completely subordinated to Victorians in what had been called the Australian Regiment. In order to get his force

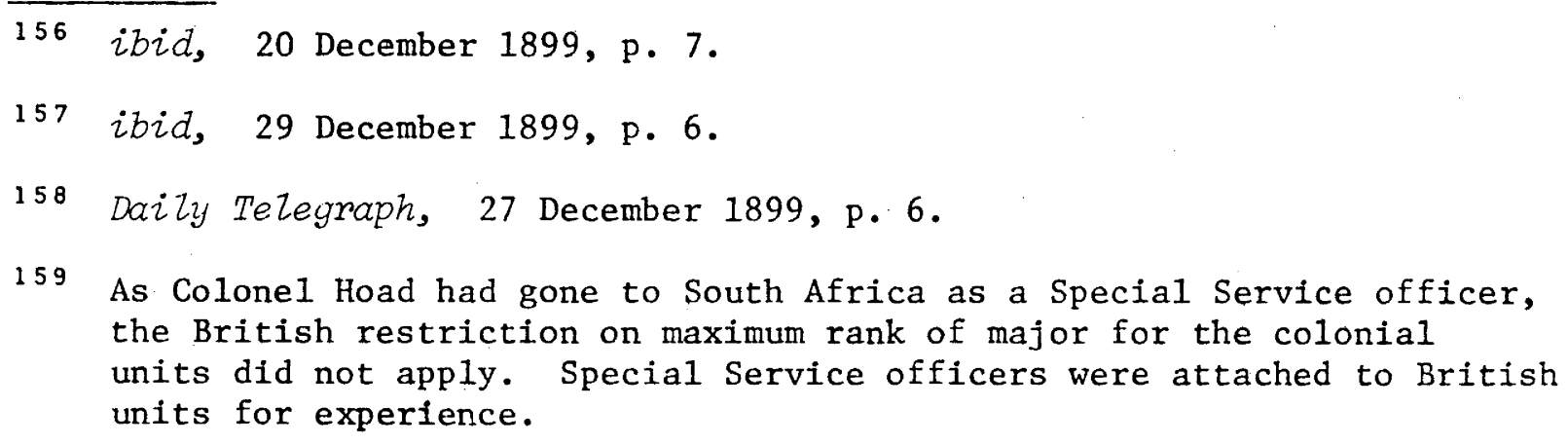
the British restriction on maximum rank of major for the colonial units did not apply. Special Service officers were attached to British units for experience. 
out of this situation, the premier cabled London requesting that New South Wales troops in South Africa be attached to similar arms of the Imperial forces. 160

The time factor indicated a clear connection between Lyne's action and the Colonial office call for units of 125 men. The press published the Colonial office reply to Lyne and the Colonial office request for small units on the same day. The former communication read:

Referring to your telegram of December $20 \ldots$ There can be little doubt that your suggestion will be adopted. The wishes of your Government have been communicated to the military authorities in South Africa. ${ }^{161}$

Lyne could hardly protest at the fragmentation of the contingent into small units readily assimilable into British brigades, and the other colonial premiers did not mourn the passing of his project.

William Lyne had come to power late in his parliamentary career, but he laboured hard to make the most of opportunities provided by the war after he assumed the premiership in september 1899. He had not been impressive in matters concerning the first contingent, but after the force had sailed Lyne moved with unnecessary haste to take the initiative in sending more troops. His first attempts were treated coolly by other colonial premiers, but the misfortunes of "Black Week" gave him his opportunity for personal aggrandizement. His ambitious plan deservedly failed, for his motives appear dishonest in the light of his attitude to the Australian Regiment. But Lyne's motives were not scrutinized in England, and the man who led the Australian colonies in a further act of loyal assistance in the troubled days of December was knighted by his Queen in mid-1900, after only nine months as a political leader.

\footnotetext{
160 Daily Telegraph, 27 December 1899, p. 6. 161 ibid.
} 
The heights of egotism reached by this mediocre politician as a result of his war-time role were revealed during question time in the Legislative Assembly. After a member had remarked on the leadership of the Australian Regiment going to a Victorian, Lyne quite seriously added, "General Buller has had the temerity to do this without consulting me". ${ }^{162}$

$$
* * * * * * *
$$

The second contingent was not raised easily although adversity had brought to the war a more heroic complexion, and volunteers would expect even greater public adulation than the first contingent received. It was harvest time in Victoria when the call to enlist went out through the pages of country newspapers to the men of the part-time defence forces, the majority of whom belonged to country units. ${ }^{163}$ Recruiting officers looked first to the Victorian Mounted Rifles for volunteers. The V.M.R., the only mounted regiment in the colony, was the obvious source for 250 mounted infantry men, but the unit's volunteering record for the first contingent had been poor. Major-General Downes, the new military commandant, hoped that the likelihood of being led into battle by their peace-time commander, Colonel Tom Price, would encourage more to volunteer for the second contingent, but after two weeks only 119 candidates had come forward out of a V.M.R. strength of over 600. Sixteen of these failed a medical test, and of seventeen married men among the remainder, thirteen were rejected because they had more than two children. ${ }^{164}$ Therefore only ninety members of the Victorian contingent were drawn from the elite Mounted Rifles. The minimum age limit for enlistment

\footnotetext{
162 N.S.W.P.D., 1899, Vol. CII, p. 3058.

163 Age, 20 December 1899, p. 7.

164. ibid, 29 December 1899, p. 6. V.M.R. strength had been slightly depleted by first contingent enlistments but was still in excess of 600 men.
} 
of twenty years would have excluded some from volunteering, and the preference for single men would have excluded others, but the response from men who had shown a liking for the military life was disappointing. Perhaps the martial needs of the bushmen of the V.M.R. were satisfied by a horse and a uniform. Whatever the reasons for the poor turn-out of mounted riflemen, the military commandant was moved to deplore publicly the performance of what he called "the pet regiment of the colony". 165

With 160 places left to fill, the military authorities were obliged to turn for volunteers to the part-time foot regiments. The personnel of these numbered thousands but they only produced 257 candidates. Medical, riding and shooting tests and family limitations reduced the aspirants to the number required. ${ }^{166}$ About 700 civilians with some military experience had volunteered, but the authorities decided to enlist serving members of the forces only. ${ }^{167}$

A press report gave a good generalised account of the second Victorian contingent. The average age was "about 24"; the volunteers from the V.M.R. were "mostly drawn from the agricultural districts" and were "sturdy young farmers and graziers"; men from the Victorian Rangers, a volunteer infantry regiment, were "mainly from the Gippsland districts... and from the dry districts of the Wimmera and the north-western parts of the colony"; among the volunteers from the militia infantry battalions were "a large sprinkling of country bred Australians and a proportion of smart young mechanics from...Melbourne and the provincial cities"; and there was a handful of professional soldiers from the permanent artillery garrisons of

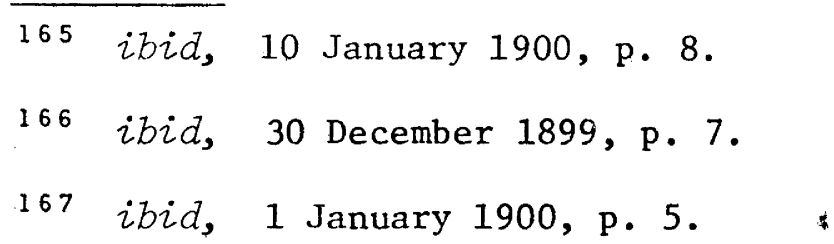


the capital. ${ }^{168}$

The military efficiency of the improvised mounted unit was questioned by a press correspondent who advocated a delay in its departure for further training. The article was discussed by the minister for defence and Colonel Price, and the latter issued a statement which branded the press report as highly coloured, and claimed that not more than twenty of the contingent could be classed as indifferent horsemen. ${ }^{169}$ Price's statement merely confirmed press suspicion that military authorities had gone close to the bottom of the barrel to get their 250 mounted infantry.

New South Wales had far more places to fill than Victoria, for William Lyne made no attempt to limit the colony's contribution to its proportional share of the mounted infantry force. His government decided on a force of 810 men, and this was raised without much difficulty, although with the aid of civilian volunteers. "A" Battery of the Royal Australian Artillery would take 175 men; 92 would go with the half field hospital; the cavalry arm would be represented by 104 members of the Australian Horse and 15 New South Wales Lancers, the latter serving as reinforcements for the Aldershot squadron; there would be three companies of mounted rifles, totalling 399, and an additional 25 men to reinforce the 1st N.S.W.M.R. in South Africa. 170

As soon as Lyne had made the offer of troops to the Home government French issued a general order to officers commanding units to supply the names of volunteers. ${ }^{171}$ There was no trouble filling the artillery unit from the keen professional soldiers of the R.A.A. The half field hospital

168 ibid, 2 January 1900, p. 6. Religions of the Victorian unit were given as: Church of England, 159; Presbyterian, 45; Wesleyan, 30; Roman Catholic, 25; and Other Denominations, 5. - Age, 8 January 1900, p. 6.

169 ibid, 10 January 1900, p. 8.

170 Sydney Morning Herald, 4 January 1900, p. 7.

171 Daily Telegraph, 18 December 1899 , p. 6. 
also gathered its complement quickly, for who could resist the honour of being called to war by a British general? ${ }^{172}$ The main recruiting effort involved the raising of the three companies of mounted infantry and, to a lesser extent, the squadron of cavalry. In the terms of French's general order, volunteers for the mounted infantry, including civilians, were to be "well trained, good shots, good riders, and medically fit for active service, between the age of 20 and 40, unmarried preferred". 173

By 11 January 1900, 1279 recruits claiming to meet those requirements had sought positions. The total was made up of 470 men from the defence forces, 52 police, and 757 civilians. ${ }^{174}$ of those, 484 passed the required medical, shooting and riding tests. The elimination of a further 84 candidates meant that only one man in very three who volunteered was selected.

This process should have ensured a good standard of entrant, but there is some doubt whether all the candidates were genuine aspirants for the contingent. Volunteers were paid from the time they went into camp to undergo elimination tests, but it was considered that this situation was being exploited by some who merely sought a few days' pay. So it became the practice to subject men to medical and shooting tests on the day of enrolment, with the result that on some days half the applicants were dispersed by nightfal1. 175

The New South Wales cabinet had favoured the Australian Horse over the other cavalry regiment, the Lancers, on the ground that the latter were already represented in South Africa by a squadron, but the embarrassment

172 General Forrestier-Walker had inspected the half field hospital that had gone with the first contingent, and was so impressed that he requested the remainder of the corps.

173 Daily Telegraph, 18 December 1899, p. 6.

174 Sydney Morning Herald, 11 January 1900, p. 7.

175 ibid, 5 January 1900, p. 5. 
caused the government by the Aldershot "rump" probably helped the decision. 176 By 11 January, 177 troopers out of an Australian Horse strength of 600 were in camp undergoing tests that would reduce them to $104 .{ }^{177}$ The Australian Horse were self-regarded and generally accepted as a regiment of bushmen, but good marksmanship was not necessarily a corollary of bushmanship. The cavalry men shot poorly. On one occasion 150 of the volunteers were tested and over 50 rejected on a trial which required a score of only 18 out of a possible 56 points for acceptance. ${ }^{178}$ When French farewelled the squadron, he praised its horses and horsemanshipbut commented unfavourably on its carbine work. 179

There were 107 applicants for 28 commissions in the New South Wales contingent. Disregarding specialists like chaplains and doctors, the number without military experience was negligible. This would have ensured the selection of a decent type of leader. Biographical sketches of the men selected show that with odd exceptions they were Australian-born or had been in the colonies for many years. They were usually educated at secondary colleges and were of good social standing. ${ }^{180}$ But the man chosen to lead the contingent was an Imperial officer, Lieut.-Colonel G.C. Knight, who was to prove an unpopular leader but who initially distinguished himself by refusing to enlist in the mounted infantry any applicant with an accent, so great was his fear of sabotage after an alleged attempt to burn the troopship, Maori. King, at Brisbane. ${ }^{181}$

176 Daily Telegraph, 25 December 1899, p. 5. Eventually a half-squadron of Lancers, raised and equipped at no cost to the government, was allowed to embark on 16 February 1900. - Sydney Morning Herald, 16 February 1900, p. 8.

177 Sydney Morning Herald, 11 January 1900, p. 7.

178 ibid, 5 January 1900 , p. 6.

179 ibid, 15 January 1900, p. 7.

180 ibid, 19 January 1900, p. 8, and 20 January 1900, p. 9.

181 ibid, 15 January 1900, p. 7. 
In South Australia, disappointment was expressed at the slowness of the mounted arm to volunteer. Of a half-company of 50 men said by their captain to have volunteered, only five turned up for a medical, and other companies showed a similar reluctance. ${ }^{182}$ Finally, military authorities enrolled 118 men, from whom they were to select 100, but it was found that many had misrepresented that they could ride and shoot. So the organisation of the contingent was held up while officers sought more recruits from both military and civilian sources. ${ }^{183}$ The final contingent relied considerably on the latter, 44 of whom gained selection. ${ }^{184}$ Other colonies went through similar difficulties to select their contingents, and it is possible to arrive at a general statement on the raising of the second Australian contingent.

As with the first contingent, there was no rush to enlist by the defence forces. Civilian volunteers showed some degree of enthusiasm, and if Chamberlain had not left the way open for their participation, military authorities would have had to pursue a far more active recruiting campaign to fill the contingent from the ranks. Of the military men who did enlist, many came from foot regiments. Add to these the civilian volunteers, with or without military experience, and you have a mounted infantry force which was far from homogeneous, and which, in part, lacked any real appreciation of the function of the mounted arm. Nor was this deficiency remedied by training, for the contingent embarked without benefit of any significant military instruction.

$* * * * * * *$

\footnotetext{
182 Age, 28 December 1899 , p. 6 .

183 Advertiser, 5 January 1900, p. 4.

184 Nominal Roll of Second Contingent South Australian Mounted Rifles, A.W.M.
} 
In general, press support for the second contingent echoed the note of solemnity and purpose that characterised parliamentary debate. Most newspapers used the war in its recent and adverse stage to point out the emergence of a new Imperial relationship in which the colonies proudly assumed their share of responsibility for the defence of the Empire. However, the radical press made its last protest before lapsing into resentful silence until the peak of war fever passed. The Catholic Press expressed alarm at the decision to send another contingent. William Lyne, it claimed, had been "intoxicated by the cheers of the thoughtless crowds", and while the journal accepted that it was the duty of professional English soldiers to obey orders, it could not countenance the action of the volunteer. ${ }^{185}$ It printed verse that ridiculed the Australian soldier:

You're a lazy lot of beggars, and you run from work that's
Seeking "glory" - dressed in khaki and in feathers.

But it expressed sympathy for the enemy:

Let go thy plough - thy rifle seize!

The plunderer seeks our soil! ${ }^{186}$

The same paper attacked another prominent Roman Catholic organ, the Freeman's Journal, for "profession of her loyalty to Judas Chamberlain". ${ }^{187}$

The Bulletin, known widely as "the bushman's bible", held that "as a whole" the sentiment of the bush was against the war. ${ }^{188}$ It showed its disdain for the city crowds who had farewelled the first contingent by suggesting that if a public holiday was proclaimed for the exhibition and export

\footnotetext{
18530 December 1899 , p. 15.

18613 January 1900 , p. 19

1873 February 1900 , p. 16.

1886 January 1900. p. 7.
} 
of a three-legged calf there would be just as many people to see it go. As for the volunteers, they "would go just as readily to shoot parrots, or Paraguayans, or polar bears, if they had the same amount of Government and newspaper backing, and the same pay, and the same chance of sport". ${ }^{189}$

Very little war writing found its way into the pages of the Bulletin, and when it did it was anti-British. Perhaps this was the result of editorial policy, or perhaps the usual contributors had no stomach for the conflict. Henry Lawson certainly did not, and his theme thatbush boredom led to enlistment, as expressed in the satirical "Blessings of War", 190 was taken up by other BulZetin poets. ${ }^{191}$ It was unfortunate that Australian blood was first spilled on foreign soil in pursuit of a dubious cause, for this situation denied to the strongly nationalistic literature of the time a stimulating subject.

All but one of the major religious denominations had clearly demonstrated their support for the war at the time the first contingent was raised. The Roman Catholic church had been more circumspect. But as the conflict became more serious its attitude, as expressed by the leading Catholic prelate in the country, became more sympathetic to Australian commitment. Cardinal Moran remarked at the time of the departure of the first contingent that true patriotism rested in staying at home to defend one's own country. 192 He repeated this sentiment at the end of the year, and was non-committal when

1896 January 1900 , p. 6.

190 BulZetin, 27 January 1900, p. 32. In this poem Lavson correctly forecasts the emergence of the soldier image at the expense of the bush ethos.

Both in letters and in art he will play the paying part (And 'tis farewell to the swagman and his mate).

191 See Bulletin', 3 March 1900, p. 7, and 16 June 1900, p. 32.

192 Age, 7 November 1899 , p. 5. 
asked where his sympathies lay in the conflict. ${ }^{193}$ But he could not remain silent in the face of the public tumult that surrounded the departure of the second contingent, and he spoke out for the British cause though his expressed reasons were decidedly sectarian. The Boers, he said, were the greatest enemies the Catholic church had ever known, but with the inevitable victory of British arms and a united South Africa the Church would have "freedom to pursue a mission of enlightenment and beneficence". 194

Cardinal Moran never enthused over the war in the manner of Anglican spokesmen. Very few Catholic clergy did. This reserve evoked criticism of the Irish-Australian population, and the extent of that criticism is suggested by Catholic reaction. At a public farewell to Father Patrick, Catholic chaplain to the second contingent, the honoured guest gave two reasons for going to war. One motive was to serve God, and the other was a desire "that by his action he should give denial to the calumny put forward by the press regarding the attitude of the Irish in Australia". 195 Archbishop Carr of Melbourne implied the existence of some sort of dichotomy of attitude along religious lines when he issued a Lenten pastoral calling for prayers for the troops in a war "in which Catholics are as vitally concerned as any of their fellow-citizens". 196

The churches were permitted to play a much bigger part in the departure of the second contingent. This was probably the result of clerical protests at the omission of the Christian element from the official farewells to the first contingent; and it may have owed a little to the greater need since December for the help of the Almighty in fighting the Boers. There

\footnotetext{
193 Daily Telegraph, 27 December 1899, p. 5.

194 Grenfell Record, 27 January 1900, p. 2.

195 Catholic Press, 20 January 1900, p. 11.

196 Advertiser, 26 February 1900, p. 5.
} 
was an impressive church parade for the Victorian unit in the grandstand at Flemington racecourse, where a crowd of 8000 sang the old martial hymns and prayed for the soldiers who "were going to South Africa in a spirit of patriotism and loyalty, which had called them from their homes to fight for their country". ${ }^{197}$ There was a high mass at St. Patrick's cathedral for Catholic volunteers, ${ }^{198}$ and Jewish patriotism was demonstrated by a service in the Bourke Street synagogue, where a patriotic address and prayers for Victorian and Imperial troops was climaxed by an enthusiastic rendering of the Anthem and an appeal for the Patriotic Fund. ${ }^{199}$

In Sydney, church parades were held at St. Andrew's, St. Mary's and Centenary Ha1l. Thousands of citizens flocked to the entrances and when the volunteers were admitted "the sea of humanity surged in at each building, fighting at the doors like beasts to gain admission". Women and children were trampled underfoot at St. Andrew's. ${ }^{200}$ The Anglican archbishop in his address claimed that the war had been forced on Britain, which was striving for "principles of liberty and justice". The congregation sang Onward Christian Soldiers and the Anthem with great fervour. The Catholic archbishop moralised on the need for piety and fidelity in the warrior, and the congregation sang O Salutaris, Tantum Ergo, and the HalZelujah Chorus. ${ }^{201}$ If the Catholic church was to go along with the war, it would do so with restraint. The most intimate of the Christian farewells occurred in Western Australia, where Anglican and Catholic volunteers breakfasted with their respective bishops after valedictory church services. ${ }^{202}$

\footnotetext{
197 Argus, 8 January 1900 , p. 6.

198 ibid.

199 Age, 15 January 1900, p. 6.

200 ibid, p. 5.

201 Sydney Moming Herald, 15 January 1900, p. 7.

202 ibid, 29 January 1900, p. 8.
} 
Other demonstrations associated with the departure of the second contingent showed a continuing interest in the war by the people and their political and vice-regal masters. The enthusiastic public farewell in Melbourne on 13 January was taken as proof that the send-off to the first contingent was no mere passing spasm of patriotic fervour. ${ }^{203}$ After personal good-byes ("little family tragedies") at Victoria Barracks, the men were addressed by Major-General Downes. The commandant praised them as soldiers of the Queen and of Victoria who were going to stand shoulder to shoulder with British regulars against a gallant foe. He knew that they would act up to the traditions of their British forefathers but he feared their lack of discipline. Then it was on to Government House where the governor and the premier addressed them. Lord Brassey eulogized their patriotism and thanked them on behalf of the Queen, "the old country" and "the United Empire". McLean, who had a son in action with the 1st V.M.R., spoke with obvious feeling when he wished the men a safe return to their "dear native land". But it was the crowd in the streets on that fine Saturday afternoon which provided the heady wine in the feast of adoration. As the contingent swept into the streets with an escort of 4500 members of the defence forces, the crowd went wild. People waved "clouds of Union Jacks", they cheered, and young ladies broke from the throng to kiss sun-tanned heroes. Colonel Tom Price, proud leader of the contingent and no longer the legendary scourge of striking unionists, was treated to cheers and handshakes. Above the marchers were stretched silent tributes - huge banners which proclaimed: "For Queen and Empire"; "Soldiers of the Queen - God Speed"; "Victoria's Sons will do their duty"; and "The Empire one and undivided, the world we defy". On then to Port Melbourne pier and embarkation, with a vast crowd formed outside the gates cheering and singing, and otherwise diverting themselves by hanging an effigy of Kruger.

203 Age, 15 January 1900, p. 6. 
A "myriad small craft" followed the Euryalus down the bay. One specially chartered launch carried the Harbour Trust Commissioners, Melbourne City councillors, and their families and friends. A larger vessel carried the official party of 400 - parliamentarians, public service and military notables, and theirfamilies and friends. No-one had thought to invite members of the Legislative Council on a similar trip to farewell the first contingent, but they had not been overlooked on this occasion. "There was scarcely an absentee member of the Council, and they showed they could appreciate the good things of a Parliamentary trip with the best of the Labour party". From a vantage point on the official vesse1, McLean led "three cheers for the brave fellows of our contingent" as the troopship moved out to sea.

On the way home, the government whip took up a collection for the Patriotic Fund which yielded five pounds. A similar benevolence towards the dependants of those who would be maimed and killed in the service of the Empire was displayed by the huge crowds which witnessed the march. Thirtysix firemen and naval brigade members were employed on an incentive basis to work the thronged streets for donations for the Patriotic Fund. They collected $£ 126.2 .11 \frac{1}{2} .204$

Sydney said farewell to the New South Wales contingent on Wednesday, 17 January. The sun shone and the wind blew on crowds that had been boosted by a government half-holiday for the occasion and a voluntary closure at one o'clock of most businesses. In the words of a leader writer, the sendoff was "a popular demonstration of national unity and enthusiasm which Sydney has certainly never witnessed on the same magnificent scale before". The streets were gay with flags and with banners that carried patriotic slogans. There was a cheer for Sir George Dibbs who once again marched at the head of the National Guard, and cheers for parliamentary ministers who 
formed part of the great martial procession in their carriages. William Lyne won his due acclaim and he responded by vigorously raising his hat. Earl Beauchamp was there in the uniform of honorary colonel of the Australian Horse. But despite all the pomp and circumstance, the march soon turned into a most unmilitary spectacle as friends mingled with the marching columns and "all order was annihilated". Civilians carried soldiers kits and rifles (the latter often ornamented with flowers), and soldiers imbibed freely the liquid gifts of elated citizens. ${ }^{205}$. The Bulletin carried an account of the event that was exaggerated in style rather than in content:

The march began decently, but in its latter moments
it was just as orderly as the downhill rush of the
Gadaren (sic) swine, and the evil spirit of Hot Beer
was in it, and it knew not where it went, or why. ${ }^{206}$

Enthusiasm did not stop at the docks, for a multitude of small craft followed the troopships down the harbour. Forming part of this small fleet were three vessels carrying an official party of over 2000 , made up of members of both Houses, senior public servants, military officers and other dignitaries, and their ladies. ${ }^{207}$ Somewhere amid the tumult of the day Lyne was able to promise the troops glory amid the hardships of war. "You will make a name for us such as rarely falls to the lot of a youthful country", he said, and he assured them that "a generous Government and a generous public" would take care of the loved ones of those who fell. 208 In Adelaide, a half-holiday for schools helped swell the crowd which was reckoned at "quite 50,000". The display of enthusiasm "was unparalleled in the history of the colony". ${ }^{209}$ Lord Tennyson bid the troops

205 Sydney Moming Herald, 18 January 1900, pp. 6-8.

206 Bulzetin, 27 January 1900, p. 8.

207 Sydney Moming Herald, January 1900, pp. 608.

208 Creswicke, South Africa and the Transvaal War, Vo1. 3, p. 149.

209 Sydney Morming Herald, 27 January 1900, p. 9. 
God-speed in the name of Queen and Fmpire and South Australia. Lady

Tennyson shed a "woman1y tear" at the impressive sight of bronzed young men marching off to fight the Empire's battles. The minister for defence assured the volunteers that they were going to fight for the liberty of their fellow men and for the defence of their country and their Queen. ${ }^{210}$ In Western Australia, the colony's unit paraded through the streets of Perth with the men from New South Wales and South Australia. "Patriotism ran rampant" and the soldiers were feted for two days. ${ }^{211}$

Regarded superficially, the second contingent and the war for which it was bound had the enthusiastic support of virtually all Australians. Even the radical press was beginning to temperits traditional anti-Imperialist viewpoint in the light of the threat to Imperial prestige and the public pressures that followed thereon; and the Roman Catholic church had accepted the military expedition to South Africa. But beneath all the cheers and patriotic cliches there existed misgiving over the war. The extent of this attitude is difficult to assess for the vehemence of the pro-war forces soon stifled it, but evidence suggests it was of significant proportions. In the first six months of the war, particularly the three months following the shocks of "Black Week", there were numerous instances of individuals, the press, local government bodies, and governments laying complaints or taking action against alleged pro-Boer sympathisers. Admittedly, many allegations were based on the flimsiest of grounds, but when all allowances are made there remain reasons for believing that many Australians were opposed to the war.

The Grenfell Record, when describing reports of alleged Boer cruelty to women and children, considered that the "indignation of even the 210 Advertiser, 27 January 1900, p. 7.

211 How Westralia's Sons Served the Empire (Melbourne, n.d.), p. 11. 
anti-Britisher and Boer sympathisers in our midst must be aroused". 212 The Daily Telegraph printed an item from Gundagai which claimed that the amount of sympathy shown in the district for the Boers was "anything but creditable to a British community". ${ }^{213}$ The Sydney Moming Herald saw fit to publish resolutions of the Durban Church Council justifying the war because of the view "in certain quarters" that the war was unjust. ${ }^{214}$ Following on a sermon by the rector of St. Andrew's, Goulburn, which opposed Australian participation, it was reported that the sentiments expressed "caused a great deal of discussion in town..., by no means altogether antagonistic to the preacher". 215 A pro-Boer demonstration was actually held in the Sydney Domain but was broken up by opponents who assaulted the speakers. ${ }^{216}$

The electoral fate of some politicians who opposed the war was used by sections of the press to show the reaction of the public to "Boer sympathisers". 217 But electoral results can be used to indicate widespread support for men who refused to countenance the war in any way. In the 1898 election for the seat of Grenfell, W.A. Holman beat his opponent by 1115 votes to $892 .^{218}$ When Holman faced the electors again in 1901, after uncompromising opposition to the war and consequent denigration by the press, he retained his seat by 1289 votes to $1200 .^{219}$ H.B. Higgins was defeated in the Victorian elections of November 1899, but the figures show he was well

21214 October 1899 , p. 2 .

2.1320 December 1899, p. 8 .

21418 January 1900 , p. 9.

215 Daily TeZegroph, 24 October 1899 , p. 6 .

216 Age, 13 November 1899, p. 5.

217 The Argus listed seven members of the Victorian Legislative Assembly who opposed the sending of the first contingent and who were defeated in the November elections. - 2 November 1900, p. 5.

218 Daily Telegraph, 28 July 1898, p. 6.

219 ibid, 5 July 1901, p. 6. 
supported. ${ }^{220}$ And when he stood for Northern Melbourne in the first federal elections he was elected by what he claimed was the largest majority over a second candidate achieved by any member in the new parliament. ${ }^{21}$ John Murray was returned for Warrnambool in 1897 by 860 votes to $629 .^{222}$ Although he led the Labour party in bitter opposition to the first contingent and was attacked both inside and outside parliament for "disloyalty", he retained the seat in the November elections by 1035 votes to $990 .{ }^{223}$

It was easy to point to reduced winning margins as proof of public disapproval, but the simple fact remains that a majority of voters in certain electorates favoured candidates who were unequivocably opposed to the war. Other factors may have influenced their support: perhaps the war was not a major issue with them. This would indicate apathy towards Australian involvement, and a fair inference could be that the three major political opponents of the war were returned by people who thought as the candidates did or did not care that they thoughtas they did.

Repressive action taken by a whole range of persecutors from governments down to individuals would indicate widespread disaffection over Australian participation, if it did not indicate primarily a state of war hysteria. The phenomenon was remarked upon by the Sydney Moming Herald. A leading article noted "something resembling a heresy-hunt" which revealed itself in "a tendency to suspect people of disloyalty because they happen to express themselves freely about the war". It also noted that it was usually public servants, especially schoolteachers and policemen, who were singled out for attack and mostly on "trivial charges of disloyalty". 224

220 The result for Geelong (two members returned): Gurr 2070, Andrews 1880, Higgins 1642, Brownbill 682, Leon 642 - Argus, 2 November 1899, p. 6.

221 C. of A.P.D., 1901-2, Vol. 7, p. 8753.

222 Argus, 15 october 1899, p. 7.

223 ibid, 2 November 1899, p. 7.

22410 February 1900, p. 8. 
The New South Wales government was not slow to move on reports of

"disloyalty". Its main inquisitor was J. Perry, minister for public

instruction. Perry, acting on information that "several" schoolteachers

had expressed disloyal sentiments, began an independent inquiry into one case

he considered worthy of investigation.225 A fortnight later he reported that

there was no foundation for the charge. ${ }^{226}$ But he considered that his zeal

had not been in vain. When unveiling a memorial tablet to the second New

South Wales soldier to die at the front (a schoolteacher), he spoke of rumours

which accused teachers of telling pupils that the war was unjust. "He had

felt strongly on the subject, and at once put a stop to anything of this kind, and he believed that there was now in his and all the departments a unanimous feeling of loyalty to the Empire".227

Further government action which may have encouraged this "unanimous feeling of loyalty" was directed against a Newcastle policeman. Following a Police Board of Inquiry the constable was dismissed from the force on the grounds that, while in uniform, he "loudly protested in public places, including the railway station and tram cars, against the action of Great Britain in regard to the Transvaal war and applauded the Boer victories".228

An Adelaide newspaper reported that claims were frequently made that South Australian public servants were disloyal in their attitude to the war. The government investigated all such reports and warned of instant dismissal if "disloyalty" occurred again. 229 The Western Australian government was said to be investigating treasonable utterances among railway, customs and police employees at Albany. 230

225 Age, 18 January 1900, p. 6.

226 Sydney Moming Herazd, 5 February 1900, p. 8.

$227 i b i d, 17$ March 1900, p. 10.

228 ibid, 13 January 1900, p. 10.

229 Advertiser, 12 January 1900, p. 4.

230 ibid, 23 February 1900, p. 5. 
W. McCulloch took a strong line against Victorian "disloyalty". In a discussion in the Legislative Council he called attention to action taken by other colonial governments, and asked the premier to proclaim that summary dismissal faced any Victorian public servant guilty of uttering disloyal expressions. McCulloch based his move on a conversation with the stationmaster of a "large central country station" who stated that the place "was seething with disloyalty". He was informed further that a similar state of affairs existed at another large country station and at several smaller ones. He also received letters complaining of disloyalty at Flinders Street, Spencer Street and Prince's Bridge stations. Other informants had reported that a police constable in a large Gippsland town had expressed the hope that the Boers would win, that two disloyal men in an office at the Education Department were constantly jeering about the war, and that a schoolteacher was advocating the Boer cause.

The responsible minister assured McCulloch that "if any Boer sympathisers came under the notice of the Government, whether they received Government pay or not, the Government would know how to deal effectively with them". The government had received a few anonymous letters but inquiries had revealed little substance in the charges. ${ }^{231}$

The heresy hunt bore fruit when a public meeting of civil servants was held in Melbourne to express sympathy with Great Britain and to raise funds for the third contingent. The seconder of the loyal motion admitted to "a small leaven of disloyal persons in the service", who had been quietened however, by the weight of public opinion. ${ }^{232}$ Some Victorian police likewise became zealous contributors to patriotic funds as a defensive gesture against public criticism. ${ }^{23} 3$

\footnotetext{
231 Age, 24 January 1900, p. 5.

232 ibid, 23 January 1900, p. 6.

233 Argus, 31 January 1900, p. 8.
} 
Local government authorities also felt it their duty to respond to activities they considered to be disloyal. At Ballina in New South Wales, the council resolved to employ no person who was known to be disloyal to the British cause in the present war, or expressed pleasure or satisfaction when the British suffered reverses. ${ }^{234}$ A number of instances of local government activity in support of the war occurred in Victoria. The Eaglehawk Borough Council resolved to dismiss any employees "proved to have used disloyal expressions towards Her Majesty and the troops in South Africa". ${ }^{35}$ The Warrnambool Water Trust did 1ikewise, ${ }^{236}$ and so did Prahran Council. ${ }^{237}$ Kew Council allowed a similar motion to lapse because if passed it would have reflected on the body of council employees, but discussion indicated that any offenders would be dismissed. ${ }^{238}$ All but one member of Mudlawirra South District Council walked out and refused to serve with the chairman, A. Both, because of alleged pro-Boer utterances. Mr. Both denied having said that one Boer was equal to nine Englishmen. ${ }^{239}$

Unofficial groups of citizens also took action. Loyalists posted placards around Stawell requesting "that all true British subjects ... should boycott any person, whether in the Government service or in business who ... makes bold to openly avow themselves (sic) Boer sympathisers". ${ }^{240}$ Horsham and Mt. Gambier carried out the same exercise against "disloyalists", 241

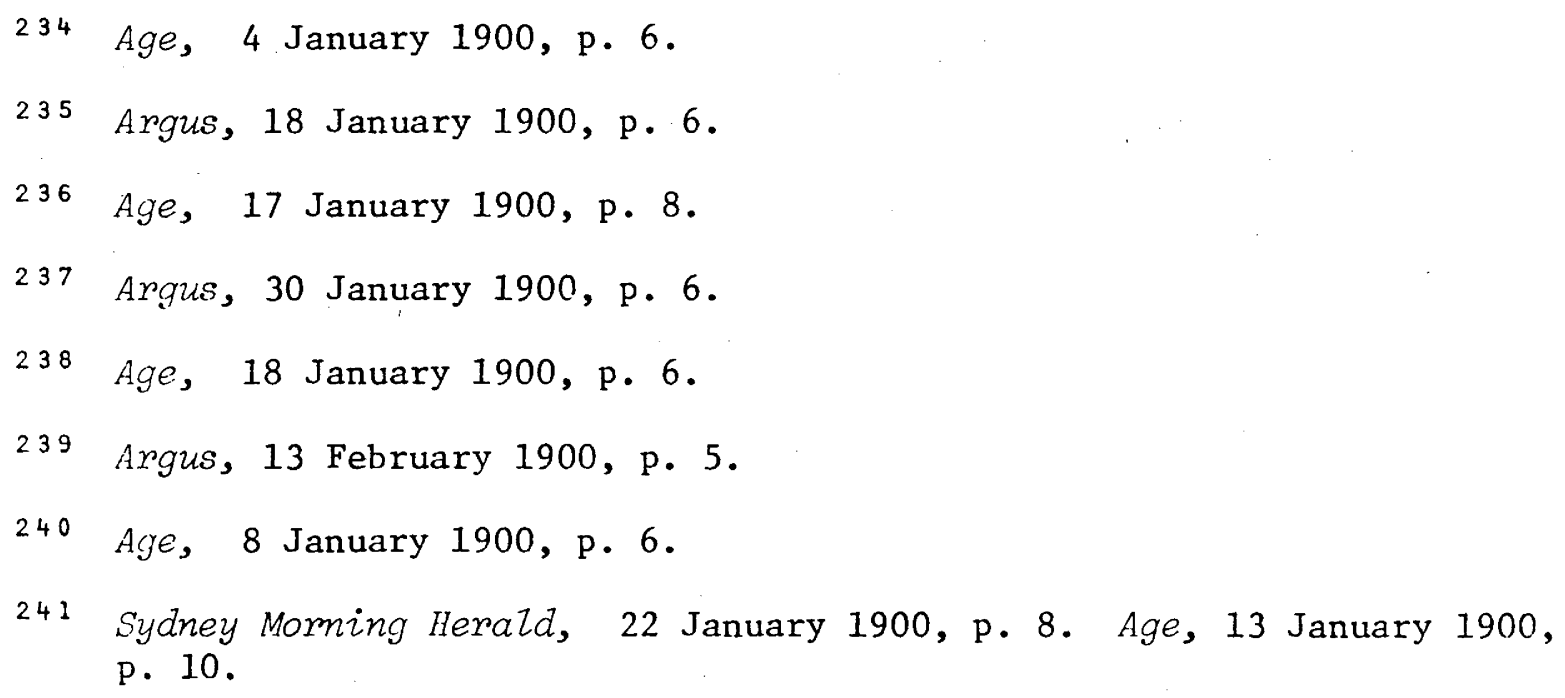


and residents of Charlton formed an "Anti-Boer League" pledged to boycott businesses whose proprietors expressed pro-Boer sentiments. ${ }^{242}$

An overflow meeting at Murwillumbah resolved:

That in view of the reported disloyal utterances of persons in receipt of Government moneys in this district this meeting requests the heads of departments to make the fullest investigations into the same with the object of procuring the instant dismissal or disqualification of such traitors. ${ }^{243}$

And a meeting of raspberry pickers at South Wandin in Victoria resolved not to pick for any grower with pro-Boer sympathies, and to duck in the creek and drive from the field any picker with similar feelings. ${ }^{244}$ But for an individual effort in what passed for patriotism none could beat the proprietor of a steam thresher, who announced that he would not employ anyone with Boer sympathies, and then set out through the Victorian countryside with a Union Jack flying from the engine funnel. 245

Sections of the German population in Australia may have expressed some sympathy with the Boers, or they may simply have remalned aloof from the patriotic excesses of the time. Whatever the case, they aroused the ire of bodies of citizens. At Natimuk in Victoria, a sports meeting was halted while German-born residents and those who resented their alleged Boer sympathies fought an hour-long battle. ${ }^{246}$ In South Australia, 4,000 Moonta residents paraded to mark their disapproval of "the Pro-Boers of Moonta ... mostly Germans". The crowd sang patriotic songs, made patriotic speeches, and burned

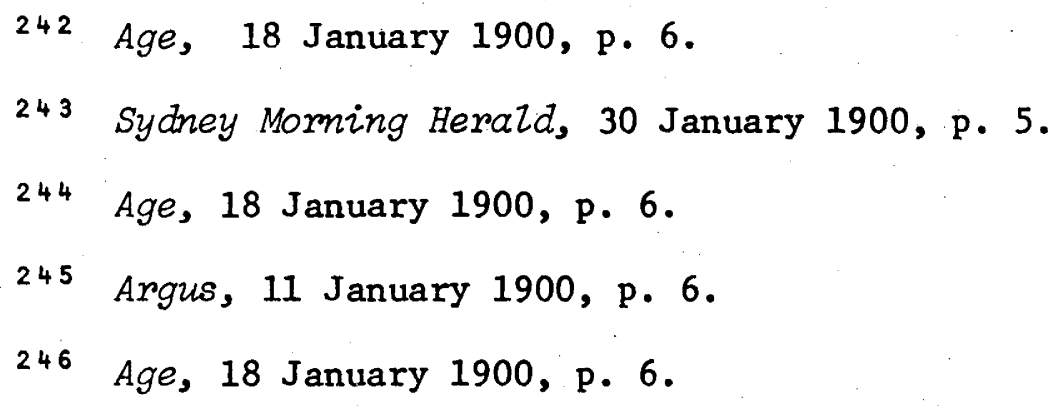


effigies of local citizens who were regarded as being sympathetic to the enemy. 247 And in Broken Hill, the German Club was stormed by stone-throwing mobs. 248

In just four months from October 1899 the Australian colonies had pledged and re-pledged themselves to war, and had honoured those pledges amid scenes of wild and apparently unqualified enthusiasm. But how complete was support for the war? Parliamentarians were almost unanimously in favour, but they, with few exceptions, were the most devoted of Imperialists. The great bulk of the press was clamorous in its support, but it too was strongly Imperialist in sentiment. The Protestant clergy were great proponents of Empire, and the Catholic clergy were inclined to be so. Very limited antagonism could therefore be expected from the articulate sectors of society. There is little reason to believe, however, that these sectors formed the tip of an Imperialist iceberg, the nether positions of which represented the Australian people; for there is evidence of an amount of opposition to the war from among the silent majority. The extent of that opposition is difficult to estimate. The indifferent response by the defence forces to the call to arms could have been influenced by public distaste for the adventure, for general acclamation of the volunteer is a main factor in most successful recruiting campaigns. The wild scenes in the streets could, of course, be taken as mass support for the war if they did not primarily indicate a spectacle-starved populace whose enthusiasm was to dwindle after a surfeit of parades.

The campaign against the "pro-Boers" also pointed to the existence of a body of opposition, for the attacks were too widespread not to have some

247 Sydney Morning Herald, 22 January 1900, p. 8.

248 Age, 8 January 1900, p. 6. 
factual basis, and they were so virulent that their purpose must have been to intimidate persons who were or might become sympathetic to the Boer cause. Intimidation had its effect, because after the wild accusations of the early months of 1900, very little happened to give further cause for criticism by the advocates of Australian participation, and the question of the magnitude of Australian opposition to the war became quite unanswerable. 


\section{CHAPTER III}

\section{The First and Second Contingents \\ IN THE FIELD}

The war in South Africa began officially on 12 0ctober 1899, and it ended on 31 May 1902. No-one with any inkling of the respective military strengths of the protagonists would have envisaged a conflict lasting for more than two and a half years, but then no-one would have foreseen that the superiority of the British Empire in treasure and in men would be countered in part by factors peculiar to this war.

During the course of the struggle, Britain and her colonies committed 448,435 troops. The two Boer republics, the Transvaal and the Orange Free State, supplemented by rebels from Cape Colony and small numbers of mercenaries from America and several European countries committed an estimated $87,000 .^{1}$ To take a more specific figure, by November 1900, 195,000 British troops faced a estimated 30-50,000 Boers. ${ }^{2}$ This numerical superiority was more apparent than real, for the British force was predominantly infantry while the Boer army was fully mounted. A preponderance of foot soldiers was appropriate to a conventional war, but the South African War turned out to be anything but conventional, although British generals did their utmost to employ traditional military tactics in the early months of the conflict. This brought into confrontation two fundamentally different military systems, and it was the Boer system which prevailed in so far as the British had to adapt to it as best they could. Frontal attacks on concealed Boer positions by stolid infantrymen marching in close formation had to be abandoned, for the British had to face the scourge of the modern high-powered rifle. The

1 Sir Frederick Maurice (ed.), History of the War in South Africa, 1899-1902, (4 Vols., London, 1906), Vo1. IV, Appendices 13 and 20. Hereafter, official History.

2 ibid, Vol. IV, Preface. 
highly efficient . 276 German Mauser was the standard Boer weapon, and it would kill at 2,500 yards. Boer tactics were geared to the Mauser. A rifleman could conceal himself on one of the myriad kopjes (small hills) which dotted much of the landscape of the battle area, and at a safe distance take unhurried aim at the enemy advancing over open country. Nor would his firing reveal his whereabouts, because for the first time in history smokeless powder was used in war. Having taken toll of the oncoming force, the Boer would abandon his position, which no longer served any meaningful purpose, and, superb horseman that he was, would scamper to safety. The Boer soldier despised unnecessary self-sacrifice and scorned the heroics of war, thinking it more sensible to live to fight another day. His readiness and ability to break off an engagement when it suited him completely spoiled British tactics. It also greatly irritated his enemy, including the Australians, who deplored the fact that the Boer would not stand and fight. The bayonet was not a part of Boer equipment, so there was no chance of the toe to toe combat that Australians seemed to favour.

The British army found it difficult to adjust to Boer methods of warfare, for according to The Times History it was not composed of very adaptable material. The common soldier was recruited mainly from the ranks of the unskilled town labourer, and in physique and intelligence was below the nation's average. Officer training was stereotyped and failed to develop initiative, and the majority of the generals were incompetents who had risen through seniority, or a successful expedition against native forces, or by social influence. "Regarded as an institution ... the British Army of 1899 was undoubtedly a success" said the critic, but "as a fighting machine it was largely a sham". ${ }^{3}$ Any war would have created problems for the Imperial

3 Vol. II, PP. 26-40. 
military structure, but its troubles were multiplied by the novel character of the South African War.

However, one section of the Imperial forces which found adaptation to the Boer fighting style relatively easy was the colonial component. During the course of the war 30,628 volunteers were drawn from the overseas colonies and an estimated 52,000 from South Africa. ${ }^{4}$ These men were better able to endure the rigours and disease of veldt warfare, and better able to find their way in the vast land and live off its resources. Above all, they were horsemen and as such they doubled the mounted force in an essentially equestrian war, although they comprised only twenty percent of the South African Field Force. The colonials, therefore, despite their limited military training, were able to make a contribution to the war quite out of proportion to their numbers.

The South African volunteers, formed into some ninety different corps, were not uniformly good. The overseas colonials won a much more favourable reputation and Australians, numbering 16,378 men, comprised more than half of this category. The six Australian colonies sent their troops to South Africa in eight contingents (see Appendix C) but it was the men of the first two contingents who did most to create an image of the Australian soldier. Drawn mainly from the part-time defence forces, these 3,000 volunteers took part throughout 1900 in the great sweeping manoeuvres of Lord Roberts which reduced the war to purely guerrilla operations. Their work was almost completely separate from that of the third and fourth contingents. These were the Bushmen's corps of raw citizen soldiery who arrived in Africa hot on the heels of the first contingents, but who were destined for operations peripheral to Roberts' thrust into the Boer homelands.

4 Official Histom Vol. IV, Appendix 13. 
The voyage to the Cape took about four weeks from the eastern colonies, and life aboard the transports was arduous for the mounted men in particular. They were in almost constant attendance on their horses. The infantry fared better, but for all troops there were parades, drills, lectures and occasional shooting practice at boxes thrown into the sea. The men accepted the routine readily enough, for the great majority had received the benefit of some military training and were keen to get on with the business of war.

The monotony of the Indian ocean was broken for the men of Queensland's second contingent when an attempt was made to set the Maori King on fire. There had been a previous attempt to burn the ship before it left Brisbane. This time the incendiarist came closer to succeeding when he poured kerosene on hay in the hold and ignited it. Luckily the fire was detected in an early stage and tragedy was averted. Much to the disappointment of many, who had regarded German crew members as potential saboteurs, the culprit turned out to be a Briton. ${ }^{5}$

Unfortunately there was widespread theft of personal equipment aboard the transports. A propensity among Australians to regard items of government issue as fair game was aggravated by regular kit parades, which led to disciplinary measures against soldiers with deficient kits. ${ }^{6}$

Despite the strained relationships which must have resulted from the high incidence of petty theft, harmony generally prevailed aboard the transports. There was one intercolonial incident, however, which cast its shadows before it. It involved officers jealous of command.

5 Letters of Charles B. Holme, Letter of 14 February 1900. Microfilm, M.L.

6. See Alured Kelly, "Personal Account of Service with 2nd Victorian Contingent", File 419/54/5, A.W.M., p. 3; A.B. Paterson, Hoppy Dispatches, (Sydney 1935) P. 3; Diary of Trooper W.A. Stee1, 1st N.S.W.M.R., A.W.M., pp. 7-9. 
Shortly after the Medic sailed from Melbourne, Major G.A. Eddy of the Victorian infantry unit made a move to assume responsibility for the Tasmanian contingent in addition to his own command. Eddy was acting under Queen's Regulations which gave command of troops on a transport to the senior officer, but Captain C. Cameron of the Tasmanians wished to retain separate command of his unit. ${ }^{7}$ When informed of the situation, the Victorian minister for defence suggested to the premiers of Tasmania, South Australia and Western Australia, the colonies sharing the Medic, that there was no need for any officer to interfere with the unit of any other colony. But should the occasion artse when a decision of the senior officer was required, the parties involved should defer to Colonel J.C. Hoad, a Victorian among a small group of Australians known as Special Service officers, who were proceeding to South Africa for experience with British forces. At the same time McCulloch instructed Eddy to restrict his command to the Victorian force. ${ }^{8}$ McCulloch's recommendations were accepted by the other colonies, and the Australian forces aboard the Medic proceeded to South Africa under four distinct commands.

The first contingent arrived at the Cape just before "Black Week". At the time Britain had four armies deployed. General Sir Redvers Buller, commander-in-chief in South Africa, was bogged down in Natal before the main Boer thrust which had succeeded in investing Ladysmith. General Sir W. Gatacre was operating in north-eastern Cape Colony against a Boer invasion which aimed at inciting rebellion among the Dutch population. General John French was facing a similar invasion in the Colesberg district of northern Cape Colony. In the west, Lord Methuen was moving uncertainly towards besieged Kimberley. The British were on the defensive, although the Boer advances had lost much of their momentum through the investment of Mafeking, Kimberley and Ladysmith.

7 Argus, 31 October 1899, p. 5.

8 ibid, 1 November 1899, p. 7. 
The second week of December confirmed what the first weeks of the war had suggested: that British generalship was deficient and that British scouting was all but non-existent. Out of the catastrophe of Magersfontein, Stormberg, and Colenso some good did come, however. The Empire drew closer together, and Lord Roberts was appointed to take over from the indecisive Buller.

The events of December were important to the Australians for they exposed the limitations of the professional British soldier and his leaders. The obvious inference was that unorthodox tactics were called for, and in this direction the colonial irregulars felt they had a peculiar competence. The whole situation was a boost to their confidence. The appointment of Roberts also favoured the colonials, for the new commander advocated flanking movements and stressed the need for better scouting. Both these tactics demanded good horsemen, and the best horsemen were colonials. But Roberts did not sail for the Cape until 23 December 1899, and the men of the first contingent were to see some action before they came under the command of the charismatic field-marshal.

The New South Wales Lancers bound from England were the first colonial troops to land in South Africa, thus fulfilling the ardent wishes of William Lyne. On 2 November 72 of them went ashore, lacking horses and adequate equipment. These deficiencies were remedied sufficiently to allow 29 Lancers to go forward and join Lord Methuen's force at De Aar, where it was poised for the drive north towards Kimberley. The remaining 43, when horsed and equipped, joined French's cavalry brigade in the Colesberg area, where they were reinforced by a detachment of 36 Lancers from New South Wales in early December.

The rest of the first contingent were initially located at points along, the western railway. The N.S.W.A.M.C. opened a hospital at Orange 
River station. The Q.M.I. went to Belmont, the N.S.W.M.R. to De Aar, and the V.M.R. and all infantry units to Enslin. To many of the troops it seemed that their worst fears were realised. They were relegated to a line of communication role while the real action was going on in Natal and with Lord Methuen's force towards the Modder river. The Colesberg area was also regarded as a minor front.

The first Australians to see action were the 29 Lancers who had joined Methuen's column. 9 The general moved out from the Orange river on 21 November with a force of $8,500 \mathrm{men}$, only 850 of whom were mounted. His objective was to relieve Kimberley but the imbalance of his column, poor scouting, and poor tactics led to Methuen's having to turn back on his heels after a troubled advance of three weeks' duration. At Belmont, a Boer force of about 2,000 attacked the British flank, inflicted sharp casualties, and then broke off the engagement. Methuen's cavalry and mounted infantry were unable to halt the retreat and bring the Boers to battle because of their limited numbers and because their horses were exhausted from reconnaissance work prior to the battle. The fight at Graspan showed a similar deficiency in the mounted arm. At Modder river, Methuen compounded his difficulties by making a frontal attack on a strong Boer force which retreated with impunity after leaving 71 British dead on the field. The battle of Magersfontein emphasised Methuen's tactical incompetence and resulted in even heavier casualties before the British force retreated to the Modder. ${ }^{10}$

9 This neglects expatriate Australians who fought in Natal with the Imperial Light Horse, an Uitlander corps. Australians formed up to ten per cent of the original regiment, and one of their number, Major Karri Davies, helped found it and was its second-in-command. - G.F. Gibson, The Story of the Imperial Light Horse in the South African War, (n.p.p., 1937), pp. 16, 20.

10 Official History, Vol. I, pp. 211, 227-51, 311-329. 
The troop of New South Wales Lancers could hardly have been

expected to play a significant part in Methuen's advance, because its numbers were negligible in a mounted force which itself was almost completely ineffectual. But partisan accounts capitalised on the fact that the men had been exposed to shot and shell. One writer stated that their part in the advance had brought the Lancers "into great prominence".11. Another claimed that Methuen "repeatedly complimented them in person on their steadiness under heavy fire", and said that the British regiments gave them the title of the "Fighting Twenty-Nine".12 And another wrote that they had won the acclaim of military critics for their effort at Graspan where, operating at the rear of the Boer position with 20 British regulars, they looked like being cut off by the Boer retreat but remained steady and diverted the enemy with their fire. ${ }^{3}$ The troop went south to the Colesberg area after Magersfontein and joined up with the remainder of the squadron serving under General French. They had not achieved greatness but they were in peril of having it thrust upon them.

Methuen's defeat marked the beginning of "Black Week", and as the year drew to a close, gloom settled over the Empire and the South African Field Force. Then came an event, a mere skirmish, which was given acclaim far beyond its due because it represented a British victory after weeks of defeat and stalemate. This time Australians formed the most significant part of the British force engaged.

On New Year's Day 1900, Colonel T.D. Pilcher, Imperial officer and commander at Belmont, led an attack on a laager of Cape Colony rebels at

11 Report of Major G.L. Lee, New South Wales Lancers, to G.O.C. New South Wales, 4 May 1900, File 565/5/2, A.W.M.

12 P.V. Vernon (ed.), The Royal New South Wales Lancers, 1885-1960, (Sydney, 1961), p. 43.

13 G.B. Barton and others, The Story of South Africa, (Sydney, n.d.), p. 49. 
Sunnyside, to the north-west of Belmont. His force consisted of 200 men of the Q.M.I., 100 Canadian infantrymen, 40 British regular mounted infantry and artillery support. ${ }^{14}$ The first casualties came when five Queenslanders on scout duty rode into strong Boer fire. The horses of Lieut. Adie and Private Victor Jones were killed under their riders. Adie was wounded but carried from the field by a comrade; Jones was mortally wounded and died where he fell, the first Australian contingenter to give his life on the South African battlefields. ${ }^{15}$

Pilcher then mounted his attack. He sent the Canadians and regulars straight at the laager, and deployed the Queenslanders in an enveloping movement on the Boer right flank, where they worked from ridge to ridge so skilfully that they surprised the enemy. Another young Queenslander, Private McLeod, was killed in the exchange of fire before the artillery helped bring the fight to a swift conclusion. The Boers retreated but the men of the Q.M.I. swept forward and took 41 prisoners. The wounded on both sides were tended by three ambulances of the N.S.W.A.M.C. which had been detached from the Orange River hospital for service with the Queenslanders. ${ }^{16}$

As the victorious troops returned to camp, the Canadians sang The Maple Leaf and The Niagara Comp Song. ${ }^{17}$ One wonders what the Australians sang. Was it Soldiers of the Queen? Perhaps this was the very first occasion when Australians felt the dire need for a national song.

The brief engagement at Sunnside had important consequences. The Times History saw the victory as one of considerable strategic importance, helping to check rebellion in the area, securing Methuen's line of communicat-

14 the Times History, Vol. III., p. 115.

15 Barton, The Story of South Africa, p. 87.

16 ibia, p. 88.

17 Creswicke, South Africa and the Transvaal War, Vo1. III., p. 65. 
ion from attack from the west, and lifting British morale after a succession of reverses. ${ }^{18}$ The stocks of the untried Australian soldiers rose sharply because of the wide and favourable publicity given to the event. Under the heading of "Colonial Gallantry" the Advertiser published a London cable which stated that the "Queenslanders behaved magnificiently throughout the engagement, and while under fire chatted and laughed together with the utmost sangfroid". 19

At least three contemporary histories of the South African War owe much to this report, each of them stressing the nonchalance of the Queenslanders under fire. 20 But the Catholic Press observed sourly that "in spite of the efforts of the daily press to swell the skirmish into a British victory it was clearly a small beer affair". 21

Another consequence of the Sunnyside skirmish is not well documented but one might presume that it came to pass. Rudyard Kipling gave it some substance in an article called "Hospital Train Number Three". The piece referred briefly to numerous occupants of the train, one of whom was a Queenslander who "blew" furiously over Sunnyside.22

The action of Pilcher in giving the Q.M.I. the key role in the Sunnyside attack when he had a company of regular mounted infantry at his disposal (they were held in reserve), showed that a British commander was

\footnotetext{
18 Vol. III, p. 117.

I 5 January 1900 , p. 5 .

20 Creswicke, South Africa and the Transvaal War, Vo1. III, p. 63; Cassell's History of the Boer War, (2 Vols., London 1903), Vo1. I, p. 371; Harding, War in South Africa, p. 590.

216 January 1900, p. 17.

22 Sydney Morning Herald, 12 May 1900, p. 9.
} 
prepared to treat the colonials no differently from the regulars. ${ }^{2}$. But there is little reason why he should not have placed his trust in a unit of confident and dashing irregulars in a small fight against a group of rebel farmers.

Two days after Sunnyside, the New South Wales Mounted Rifles also moved against the Cape Colony rebels as part of a force commanded by Colonel E. Alderson, another Imperial officer. But theirs was a futtle affair. Marching on Prieska, the column easily dislodged the few rebels who commanded the town, and 80 troopers of the N.S.W.M.R. and 25 South African irregulars were left in occupation. ${ }^{24}$ A week of cricket matches and general fraternising with the loyalists of Prieska followed, but Captain Antill of the N.S.W.M.R. led his men hurriedly out of town on reports that a large rebel force was grouping. The Boers occupied the town an hour after Antill's departure, but were driven out when Alderson came up with 1,000 troops to reinforce the former garrison. However, the column merely marched into and out of Prieska and back to the Orange River station in a fruitless demonstration of the British presence. The rebels quickly re-occupied Prieska and ordered the loyalists out because of their collaboration with Antill's command. ${ }^{25}$ Not even the most partisan of correspondents could have turned the Prieska episode into a tale of military prowess, and the N.S.W.M.R. had to wait many weeks for an engagement that lent itself to such treatment.

The Australian infantry units had to undergo trial and tribulation before they saw action. When the foot soldiers from Victoria, South Australia Western Australia, and Tasmania arrived in South Africa, together with the

23 A.B. Paterson noted this as a general tendency a little later. - Sydney Moming Herald, 9 March 1900, p. 5.

24 Official History, Vol. III, p. 3.

25 Frank Wilkinson, Australia at the Front, (London, 1901), pp. 57-60. 
V.M.R., the British command at the Cape decided to form them (and the New South Wales infantrymen when they arrived) into a force that became known as the Australian Regiment. It is not clear why the British authorities decided to depart from their original intention of attaching each colonial unit to a regular regiment as an extra company, but expediency would have been a factor in the decision. What readier way was there to dispose of five companies of colonial irregulars than to leave them in the grouping in which they had proceeded to the seat of war? Accordingly, the loose command structure which had prevalled aboard the Medic was formalised and extended. Colonel J.C. Hoad was given command, although as a Special Service officer he had proceeded to South Africa in a vague expectation that he would be given a place on General. Buller's staff. Major G.A. Eddy of Victoria was made second in charge. Captain G.R. Lascelles, an Imperial officer accompanying the South Australian contingent, was made adjutant; and Sergeant A.W. Johnson of South Australia was appointed regimental sergeant-major. ${ }^{26}$ William Lyne's hopeful boast that the New South Wales contingent would beat the Victorians to the Cape had not been fulfilled, and the result was that officers from the mother colony, arriving late, received no regimental appointments. The rancour that ensued placed in jeopardy the concept of a federal regiment.

The Australian Regiment stayed only briefly at Cape Town, where the men's physique and soldierly bearing brought favourable comment from Lord Milner, the British high commissioner, and others. ${ }^{27}$ Some attention had to be given to the regiment's uniforms, which were not federal in appearance although several colonies had achieved a basic uniformity of field service dress by 1899. The changes effected, however, were more in the interest of

26 W. T. Reay, Australians War, (Melbourne, 1900), p. 35.

27 ibid. 
safety than of uniformity. In deference to Boer marksmanship, coloured facings were removed from tunics, as were all insignia, and badges of rank; and the distinctive Western Australians had to discard their blue jumpers and blue putties in exchange for khaki gear. The superior physique of the Australians became very evident when it was found that most of the British garment stock would not fit the colonials. An important armaments change was the substitution of the magazine Lee-Metford rifle for the Australians' single-loading Martini-Enfield. ${ }^{28}$

The regiment arrived at Enslin just in time to watch the yellow lyddite shells splashing on the hills of Magersfontein, twenty miles to the north, as Methuen's Highlanders were locked in combat with General Cronje's force. And as all fell quiet on the western front the Australian Regiment took up an important but uneventful existence as one link in the chain of garrisons which protected Methuen's communications from De Aar to the Modder. "Guarding the jam" was hardly an operation to satisfy the military aspirations of the Australians, however, and discontent with the state of affairs became a factor in the intercolonial dissension which developed at Enslin.

When the regiment had passed through the Orange River station on its way north, Colonel W.D.C. Williams of the N.S.W.A.M.C. enthused over the significance of the federal force. "We have sunk all provincialism and have driven another nail for the military federation of the colonies", he wrote. ${ }^{29}$ But that was before the New South Wales infantry company joined the regiment at Enslin.

As soon as the unit arrived at the Cape its commander, Captain J.G. Legge, expressed disappointment at the amalgamation of the Australian infantry companies, because his corps was thus "prevented from gaining

28 ibid, pp. 35-6.

29 Report to G.O.C. N.S.W., 7 January 1900, File 565/5/2, A.W.M. 
experience with an Imperial Battalion". ${ }^{30}$ But after a few days at Enslin, Legge's disappointment turned to envy and chagrin because, according to him, the Victorians were "outrageously favoured in everything, even rations". So the New South Wales company commander sought to forward through Colonel Hoad a letter to British authorities asking that his unit be attached to an Imperial regiment. But Hoad refused to pass on the request. ${ }^{31}$ There was evidence that discontent at Enslin was not confined to Captain Legge, nor to New South Wales officers. ${ }^{32}$ But while the plea from several officers was for service with British battalions, the complaint was invariably directed at Victorian monopoly of senior commands in the Australian Regiment.

Letters from New South Wales other ranks at Enslin at this time voiced no dissatisfaction with the organisation of the regiment, thus adding to the impression given by the statements of disgruntled officers that the main motive for discontent was professional jealousy.

Amid the discord, Colonel Hoad tried hard to make his command succeed, and to engender into the sceptics his belief in the significance of the very first federal military force. Typical of his leadership was his visit to every tent on Christmas Day to speak to the troops. ${ }^{33}$ And at a combined colonial concert on Australia Day he reminded an audience of Australians, Britons, and Kaffirs of the new role of Australia as a partner in Empire. Then he called for cheers for Australia. ${ }^{34}$

The military situation in South Africa was changing rapidly, however, and circumstances were to cast the Australian Regiment back into fragments, thereby either denying the force the chance to show what a group

30 Report to G.O.C. N.S.W., 6 December 1899, File 565/5/2, A.W.M.

31 ibid, 28 December 1899.

32 Sydney Morming Herald, 29 January 1900, p. 8, and 31 January 1900, pp. 7, 8 , Letters.

33 Reay, Australians in War, p. 83.

34 Sydney Morming Herald, 28 February 1900, p. 7, Letter of Private E.E. Hines. 
of Australians of battalion size could do, or else saving it from the ignominy of more serious internal strife.

Lord Roberts arrived in South Africa in mid-January 1900 and immediately set about evolving a new strategy, aided by the mistakes of Buller and Methuen and his own more astute military mind. The field-marshal's first priority was to increase the mobility of his field force. He did this principally by raising as quickly as possible irregular mounted units from among the Cape colonials, and by ordering those regular infantry battalions that had not already done so to provide a mounted infantry company. Roberts knew that the Australian and New Zealand second contingents were due to arrive in February, but he looked to further help from the antipodes in the form of the Australian Regiment. Why not convert the five companies of foot to mounted infantry? So began the horsing of the Australians. At the first call for volunteers for conversion 450 men responded out of 580 . The remainder soon changed their minds and Colonel Hoad was able to offer the entire regiment as a mounted force. A war correspondent stated that "few of the men were without equestrian experience of some sort"15 but nonetheless, Enslin camp became the scene of much activity as the Australians practised their horsemanship, bareback on transport mules because there were no horses available.

Their "training" completed, the regiment moved south to the Colesberg area on 29 January where their physique again won praise, this time from a British general. But the Australians were in no mood for compliments because they considered themselves to have been cast into the military wilderness, away from the advance on Kimberley and the rumoured invasion of the Orange Free State from the west. ${ }^{36}$ Little did the men of the

35 Reay, Australians in War, p. 102.

36 Tremearne, Some Austral-African Notes and Anecdotes, p. 19. 
Australian Regiment realise that the Colesburg operations were to provide them with ample opportunity to become acquatnted with war. But before they spilled their blood upon the veldt, the Australian cavalry were to feature in an incident which did little for the embryonic military reputation of the Australian contingent.

By the end of 1899 , the troop of New South Wales Lancers who had been attached to Methuen's force rejoined the rest of the Aldershot men near Colesberg. As reinforcements from New South Wales had already joined the unit, the squadron now stood at full strength. The Lancers formed part of the command of General John French, whose function was to prevent a Boer invasion of Cape Colony and protect the flanks of Methuen and Gatacre. Also included in this force were two troops of Australian Horse who had formed part of the New South Wales mounted infantry unit of the first contingent, but who now found themselves part of the cavalry arm to which they, as part-time soldiers, purported to belong.

At dawn on 16 January 1900, a mixed patrol of 14 Lancers and 7 Australian Horse, commanded by Lieut. Dowling of the latter regiment, set. out to reconnoitre Boer positions at Slingenfontein near Rensberg. ${ }^{37}$ Perhaps the colonial cavalry were keen to the point of indiscretion; perhaps their proficiency was countered by colonial brashness and inexperience. Whatever the reason, the Australians did not exercise the great caution needed in hostile country and as they proceeded across a plain surrounded by small kopjes, they fell among a party of wrathful Boers. A.B. Paterson, war correspondent attached to French's force, was able to piece together a good account of the ambush and its tragic consequences. Dowling, when surprised, led his men towards a nearby kopje with somewhere between 40 and 100 Boers

37 Sydney Morning Herazd, 16 February 1900, p. 7. 
in pursuit, only to find the position occupied by another party of the enemy. At that it was a case of every man for himself, but a wire fence hindered escape and only 6 troopers were able to break out of the trap. Of the remaining 16, one man was killed, another mortally wounded, and 14 were taken prisoner, including several wounded men.

When the news of the disaster got back to camp, the wildly excited Australians wanted to set out immediately in the hope of aiding their comrades, but the Imperial brigade commander refused because of approaching darkness. At daylight next morning an Australian party set out for the scene of ambush, and there, amid noisy vultures that feasted on the carcases of slain horses, lay two forms. One was the body of Sergt.-Major Griffin of the Australian Horse. The other was the dying Corporal Kilpatrick of the New South Wales Lancers. Kilpatrick's lower jaw had been shattered by a bullet, and he had also been shot through the lungs. His wounds had been roughly bandaged by the Boers. It is not difficult to imagine the pain endured by the teacher from Leichhardt Superior Public School during that long night alone on the veldt, but his suffering was emphasised by the word "cold" fashioned in the dust by the finger of the dying Lancer. Griffin was buried where he had fallen. Kilpatrick died before the day had passed and was buried alongside two New Zealanders on a slope above Slingersfontein farm. ${ }^{38}$ One contemporary historian regarded the episode as "another lesson as to the need of watchfulness and most careful scouting". 39 Another suggested that the disaster "might have been averted if Lieut. Dowling had shown' little less pluck and made up for the deficiency in caution". 40 But the criticism

\footnotetext{
38 ibid, 16 February 1900, pp. 7, 8.

39 Casselz's History, Vol. I, p. 550.

40 Wilkinson, Australia at the Front, p. 46.
} 
loses some of its point in the light of a discovery by Paterson when visiting the scene of the fight a few days after the event. A Boer pony acquired by the correspondent broke away and was chased by a trooper. Soon both the pursuer and the pursued dropped out of sight on the open veldt, hidden by a depression which concealed 40 grazing mares and their foals. It was from this point that the Boer attack on Dowling's troop had originated. ${ }^{4}$

Following Slingersfontein, the Australian cavalry were retired to a rest camp at Arundel. "The loss of Dowling and his troop has cast a gloom over everything", wrote Paterson, "and it looks as if the authorities are afraid of risking any more losses to the volunteers than they can help". ${ }^{42}$ Colonel Porter, the British brigade commander, inquired into the incident and held that the ambush had been an accident and that no-one was to blame. ${ }^{4}$ However, the Lancers and Australian Horse saw no more action in the Colesberg area and by early February had moved north to the Modder with French's cavalry, leaving the defence of northern Cape Colony to General Clements and a force that included the Australian Regiment. French had done well, and The Times History specifically praised the competence of the horse artillery, "the steadiness of the Berkshires" and "the gallantry of the New Zealanders". 44 The Australians received no honourable mention. After all, they had blemished the record of the British army's premier cavalry commander.

A.G. Hales, an Australian war correspondent who later met the wounded Dowling in a Boer hospital, wrote an account of the Slingersfontein skirmish which showed that the affair was not devoid of gallantry on the part of the Australians. Dowling would not discuss his part in the fight, but Hales got it from a Swede who had been part of the Boer force. In the first

\footnotetext{
41 Sydney Morning Herald, 7 March 1900, p. 7.

42 ibid, 19 February 1900, p. 8.

43 Report of Major G.L. Lee, January 1900.

44 Vol. III, p. 143.
} 
fusillade of bullets, Dowling's horse was shot from under him and several of his men wounded. Urging the unscathed members of the troop to ride for their lives, Dowling turned his rifle on the attackers, but he was soon down with a bullet wound in the head. Then he was on his feet again, only to be felled by a shot which blew off his thumb. But he rose again, firing away with his revolver. "He looked like a gamecock as he stood there in the sunlight, his face all bathed in blood ... and his shattered hand hanging numbed beside him", recounted the Swede. Two bullets in the legs dropped him by his dead horse, but it took a blow on the head with a rifle butt to finally quieten the Mudgee lieutenant. ${ }^{45}$

An important consequence of Dowling's misfortune was the beginning in Australia of a more tolerant attitude towards the Boers. When he returned to Sydney early in May, Dowling spoke of the kindly treatment he had received as a wounded prisoner of war and testified that the Boer, in the main, was an admirable foe. ${ }^{46}$ Two days after the publication of the officer's views, the Sydney Moming Herald, in an editorial comment, praised the humanity of the Boer and noted a changing attitude in Australia which was beginning to recognize "the better personal qualities" of the enemy and "his splendid courage and constancy in a desperate cause". 47

Paterson had written in January that the British military authorities would be happy to get more colonials because of the way the Queenslanders and Canadians had fought at Sunnyside and the New South Wales Lancers elsewhere. ${ }^{48}$ Knowing the modest character of the military operations involved,

45 A.G. Hales, Campaign Pictures of the War in South Africa (1899-1900): Letters from the Front, (London, 1900) pp. 30-36.

46 Sydney Moming Herald, 9 May 1900, p. 7.

4711 May 1900 , p. 4. This editorial view would also have owed something to the reports of A.B. Paterson who, like Dowling, had come to accept the Boer as an honourable foe.

48 Sydney Morning Herald, 6 February 1900, p. 6. 
one might suspect Paterson of a lack of objectivity, but the use made of the Australian Regiment as soon as it was mounted indicates British faith in the colonials (as well as a dearth of Imperial cavalry and mounted infantry). When General French relinquished his Colesberg command to General Clements and moved north to the Enslin area to assume a position for the invasion of the Orange Free State, he took with him all but two squadrons of his cavalry. As Clements had brought with him into his new command an essentially infantry force, the new Colesberg column relied heavily on the Australian horsemen who numbered 691 in a force of $6,600 .{ }^{49}$ Boer equality in numbers and superiority in mobility placed an added responsibility on the men of the Australian Regiment. And for Clements and his force the price of failure would be great: the cutting of the life line of Roberts' gathering invasion force.

The British column took up its position along a 35-mile front which straddled the Naauwpoort-Norval's Point railway line. The left wing, under an Imperial officer,included the Wiltshire infantry, and mounted infantry from New South Wales, South Australia, and Victoria. The right wing, also under an Imperial officer, included the Worcester infantry, and mounted infantry from Western Australia and Tasmania. ${ }^{50}$ Ahead lay an estimated 7,000 Boers, so firmly positioned in the Rensburg hills that the British could do little more than show a presence and hope that the enemy would not realise too soon the numerical and tactical inferiority of the force to that of French's command. Contact between the antagonists was inevitable, and in no more than a week of severe skirmishing Clements' force was pushed back down the line to Arundel. The South African conflict

\footnotetext{
49 Official History, Vo1. II, p. 593.

50 The Times History, Vo1. III, p. 460.
} 
was the first war to be fought under the probing eye of the press. Therefore it was not inappropriate that the first Australian to die in Clements' campaign should be a journalist, W.J. Lambie, who wrote for the Age, the Advertiser and the Daily Telegraph. Lambie had been wounded when in the Soudan with the New South Wales contingent. He died in South Africa, partly out of indiscretion and partly out of an earnest desire to record the way in which Australians conducted themselves in battle.

Lambie was killed on 9 February while accompanying a small force on patrol in enemy-dominated territory. With Lambie was A.G. Hales of the London Daily News. The patrol was surprised by a party of Boers and in the melee that followed Lambie was shot dead and Hales taken prisoner. As war correspondents, both men were uniformed in the manner of British officers, and Hales was told by members of the Boer party that their dress, and the fact that they retreated so hastily, led to their being fired on. ${ }^{51} \mathrm{~W} . \mathrm{T}$. Reay of the Melbourne Herald was accorded every facility by General de la Rey to visit Lambie's grave and to obtain what information he could concerning the correspondent's death. It was the great Transvaaler himself who talked with Reay and expressed deep regret that Lambie was killed through being mistaken for a combatant. 52

In those few days of skirmishing among the Colesberg kopjes, the men of the Australian Regiment displayed an aptitude for unorthodox mounted warfare. They showed courage and a keenness to join battle with the enemy, and these qualities often manifested themselves in audacious patrolling which led to situations from which the Australians only extricated themselves by fearless riding across the bullet-splashed veldt. Two episodes stand out in those few days of baptismal fire. The first concerned the West Australians

\footnotetext{
51 A.G. Hales, Campaign Pictures, p. 21.

52 Reay, Australians in War, p. 159.
} 
at Slingersfontein, where a stand was made which did much to atone for the humiliation of Dowling's defeat at the same location a month earlier.

At daylight on 9 February a troop of W.A.M.I. under Captain Moor, and a squadron of Inniskilling Dragoons moved out from their camp on reconnaissance. Almost immediately the force made contact with a Boer commando of 300 to 400 men. The regular cavalry took up a defensive position and the West Australians were ordered to the flank, where they made a stand on a kopje which stood at the entrance to a horseshoe formed by a string of other kopjes. In an endeavour to turn the British flank, the Boers attacked the West Australian position from the hills on three sides. From sunrise to sunset the little band of twenty men defied a force of several hundred. As the day drew to a close the enemy came close enough to call on Moor to surrender, but although the troop had lost one man dead, one mortally wounded, and five others wounded, the answer from the colonials was a defiant display of bayonets and a challenge to come and get them. The troop eventually retired in twos and threes, running a gauntlet of fire as the daylight faded. ${ }^{5}$ General Clements recognised the value of the West Australians' stand in a brigade order:
The General Officer commanding wishes to place on record his high appreciation of the courage and determination shown by a party of 20 men of the Western Australians, under Captain Moor ... By their determined stand against 300 or 400 men they entirely frustrated the enemy's attempt to turn the flank of the position. 54

Rolling up the flanks of the tenuous British line became a major Boer objective, and it led to the other significant episode involving clements' Australians. The engagement at Pink Hill was the logical outcome of the

\footnotetext{
53 Reay, Australians in War, pp. 163-5.

54 ibid, p. 166 .
} 
shaky strategic position of Clements' force, combined with Australian cockiness. Pink Hill was a diminutive Anzac. It was a defeat which led to a major withdrawal from the area; it involved high proportionate casualties; and it was praised as a great display of Australian courage and honour in war.

On 12 February, the Boers attacked both British flanks. Situated on the extreme left, at Pink Hill, were 75 Victorians, 20 South Australians, 50 Inniskillings, and 50 Wiltshires. Major Eddy had assumed command of the post that morning from an Imperial officer, who had moved off with the artillery to another position. The enemy attacked in considerable numbers just before noon, and for two hours Eddy's force defended grimly from among the rocks of Pink Hill. It soon became obvious that the position could not be held and the Wiltshire infantry were evacuated first, with the mounted men remaining to cover their retreat. Throughout the battle, Eddy had moved among his men, encouraging them and directing their fire, but no sooner had he given the order for the final retirement when he fell with a bullet through the head. The Australian casualties were severe: 6 killed and 23 wounded, of whom 10 were taken prisoner. ${ }^{55}$

The right flank having also been turned, Clements withdrew his wings to the centre and fell back upon Arundel, where he assumed a defensive position until Boer pressure was relieved by Roberts' move on Bloemfontein. An Australian war correspondent regarded 12 February as "a calamitous day for the British cause" and "a glorious but a fatal day in the history of the Victorian contingent". ${ }^{56}$ The official report acknowledged the value of the "assistance rendered to their dismounted comrades of the Wiltshire Regiment by the Victorian Rifles", ${ }^{57}$ but other views of the minor engagement

$$
\begin{aligned}
& 55 \quad i b i d, \text { pp. 169-73. } \\
& 56 \quad \text { izid, p. } 169 . \\
& 57 \quad \text { ibid, p. } 181 .
\end{aligned}
$$


were less restrained. The Argus called for "a beautiful and stately monument" to the gallant dead, which would "tell to all future generations of Victorians the story of a deed which they could never surpass but from the heroic measure of which they must never decline". ${ }^{58}$ The Advertiser stated that Australians would be proud that they had not looked in vain to their representatives on the field of battle for a display of the highest military qualities, and added, "Plainly wool and wheat are not our greatest products!"59 The Times Histom, not given to high praise, noted, "As an exhibition of resolute courage on the part of comparatively untrained troops, this performance of the Australians is worthy of mention". 60 The highest praise came from the pen of Arthur Conan Doyle, a fervent imperialist whose popular history speaks only good of loyal colonials. He wrote that the Australians "proved once for all (sic) that amid all the scattered nations which came from the same home there is not one with a more fiery courage and a higher sense of martial duty than the men from the great island continent". ${ }^{61}$ But amid all the praise for the Pink Hill defence, which even more than Sunnyside was taken as marking the "arrival" of the Australian soldier, there were critical murmurings that perhaps reputation had been achieved at the expense of unnecessary life. It was considered that Eddy should have given the order to retire much earlier. ${ }^{62}$ But caution was not part of the make-up of the former school teacher who had found soldiering so attractive that he had made it his career. The night before he fell, Eddy had stood on the very spot where he was to die the next day and had remarked to friends that the position was superb for a last stand and that he would, in fact,

\footnotetext{
$58 \quad 21$ February 1900, p. 6.

5921 February 1900, p. 4.

60 Vol. III, p. 466.

61 The Great Boer War, p. 188.

62 Reay, Australians in war, p. 178.
} 
like to make a last stand there. ${ }^{63}$ Add to this heroic inclination Eddy's great contempt for the Boer, ${ }^{64}$ and we have a situation where discretion was unlikely to be regarded as the better part of valour.

Whether or not Major George Albert Eddy did aspire to glory, he achieved it in the short-term, for flags few at half-mast in his honour in allthose Victorian towns that had some claim to him. ${ }^{65}$ And although his body, together with those of his comrades, was to lie among the blood-stained rocks of Pink Hill for three weeks, he was eventually buried in a manner befitting a hero. Because of the British withdrawal from the area, no action had been taken to inter the dead, but there was supposedly an understanding between British ambulance men and the enemy that the Boers would bury the fallen on Pink Hill. This had been done in an inadequate way, although in a manner in which the Boers often disposed of their own dead, the bodies being roughly covered with boughs or rocks to keep away the scavengers of the veldt. When it was heard that the Victorians had not been properly interred a burial party went to the scene. Major Eddy's was the first of five Australian bodies to be honoured in Christian burial. Chaplain Wray, clad in full clerical vestments, conducted the service and the members of the burial party raised a huge mound over his grave. A simple head-board served to identify the lonely tomb of a man who had fought beyond doubt with defiant courage. 66

While the Australian Regiment was being put to the test on the hazardous field of Colesberg, elements of the second contingent were arriving in South Africa. Most colonial units moved up to join Roberts' invasion force at various points on his drive to Bloemfontein, but the units from Victoria and Tasmania were directed to the Colesberg area. But before they

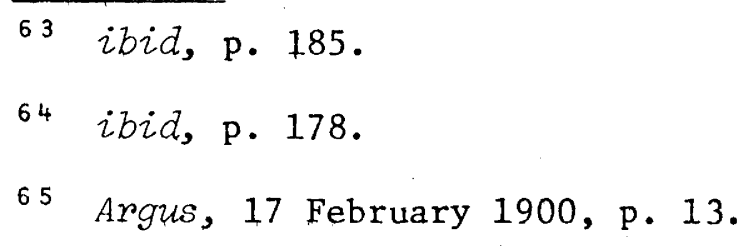


made contact with the Australian Regiment, Colonel Tom Price of the Victorians was accorded an honour, however brief, that was denied all other Australian officers throughout the war. He was given a command of his own. The Victorians and Tasmanians had been de-trained at Hanover Road while en route from Cape Town to Naauwpoort, and were brigaded with several units of British regulars and South African irregulars to form the Hanover Road Field Force under Price. The objective of the hastily organised force was to protect Hanover Road from a Boer commando reported to be in the vicinty. Despite the alarms the enemy did not appear, and Price went forward with the mounted section of his command, about 350 men, to join Clements at Arundel. Here he fought an engagement that he later recounted with pride. The objective was Kuilfontein kopje, a position crucial to Clements' march on Colesberg. On the left of the advancing British force was Colonel Page Henderson of the Inniskilling Dragoons, on the right was General Clements himself, and in the centre was Tom Price and the H.R.F.F. But most flattering of all was the presence of Kitchener as an observer.

The fight was sharp but unsuccessful despite the extensive use of British artillery, and the attackers retired. Two days later Price led his force in another assault on the kopje and took it without opposition. The Boers had begun their withdrawal to meet the main invasion threat, and the entire Colesberg force moved slowly behind them towards Bloemfontein. By this time, however, Price's command had been narrowed down to the Victorians only. Even that was something of a distinction, for the remaining Australian units moved north under Imperial officers. Price regretted the limiting of his command but the fact that he was the only Australian officer honoured with a separate command during the war remained a great source of pride to him. He was inclined to attribute the reluctance of British authorities in this matter to the existence of intercolonial jealousies. Perhaps Price had 
a point, because the bickerings of colonial officers at Enslin would not have been lost on British authorities. ${ }^{67}$

On the day that the Colesberg force began its withdrawal to Arundel, the invasion of the Orange Free State began. Roberts had gathered together near Enslin an army of 45,000 combat troops, made up of four infantry divisions and one cavalry division, each of 7,500 men, and a force of 3,600 mounted infantry. Servicing the whole was a transport wing of 4,000 drivers, 11,000 mules and 9,600 oxen. Included in this formidable array of British military strength were about 500 Australians, men from the Q.M.I.,the N.S.W.M.R., and the Lancers, all of whom were merged with French's cavalry division. ${ }^{68}$

Roberts' plan was to move to the Modder river and then strike east towards Bloemfontein, but before doing this he wanted to use French to relieve Kimberley. A morale booster was needed both in the field and at home, for Buller had blundered again in the tragic battle of Spion Kop in Natal. Roberts was also aware of "the disastrous political effect" which the fall of Kimberley would have, so he placed great importance on the relief of the diamond town. ${ }^{69}$ The brief campaign by which this was achieved was quite spectacular, and must have been a source of great pride to the small group of Australian citizen soldiers who were privileged to ride with men of illustrious Imperial regiments. To begin with, there was an inspiring address by the revered "Bobs" himself, who spoke after the fashion of a

67 Lieut. Colonel Tom Price, "Services of Victorian Troops in the Boer Campaign". Typed article, A.W.M.

68 The Times History, Vo1. III, pp. 375-7.

69 Sir George Forrest, The Life of Lord Roberts, K.G., V.C. (London, 1914), p. 201 . 
great Shakespearean warrior king:

You will remember what you are going to do all your lives, and when you have grown to be old men, you will tell the story of the relief of Kimberley. ${ }^{70}$

Then there was the move-out, when French led his 6,000 men in formation away from the main force and towards the Modder at dawn on 13 February. An English soldier was awakened by the sound of the movement of the largest British mounted force in history, and he watched in awe at what he described as one of the finest sights he had ever seen. ${ }^{71}$ Even the prosaic and egotistical Colonel Ricardo of the Q.M.I. was touched by the "glorious sight" of the sun rising on the thousands of troopers. ${ }^{72}$

After French crossed the Modder he encountered stiff Boer resistance, but used some of this crack regiments to clear the way. No Australians were involved, but in the ensuing dash to Kimberley on 15 February the squadron of New South Wales Lancers was among the vanguard. The Q.M.I. also took part but the N.S.W.M.R. were not among the 5,000 men who relieved the town. According to one of their number, General French asked the unit to accompany him but their horses "were too much done up". ${ }^{73}$ A bearer company of the N.S.W.A.M.C. added to the excellent reputation the corps had already built up through its field hospital at Orange River and its ambulance work at Sunnyside, by being the only medical unit to keep up with French's cavalry in the horse-killing ride to Kimberley. This distinction won for its leader, Lieut. C.A. Edwards, a mention in French's dispatches. ${ }^{74}$

70 ibid, p. 202 .

71 Murray Cosby Jackson, A Soldier's Diary, South Africa 1899-1901, (London 1913), p. 11 .

72 Ricardo Papers, A.N.L., Letter to Arthur Ricardo, 28 February 1900.

73 Diary of W.H. Barham, M.L., A news clip of letter to his wife, 26 February 1900 .

74 W.D.C. Williams and A.E. Perkins, "The N.S.W. Army Medical Corps", in Barton, The Story of South Africa, p. 375. 
A.B. Paterson accompanied the Kimberley relief force, and the occasion prompted him to write one of his twelve ballads on Boer War themes. The poem did not celebrate a heroic battle, for there wasn't one. But it did celebrate an event that assumed heroic proportions for Paterson and his compatriots; that is, the emergence of Australian soldiers as apparently equal and integral parts of an Imperial force of elite corps and famous commanders.

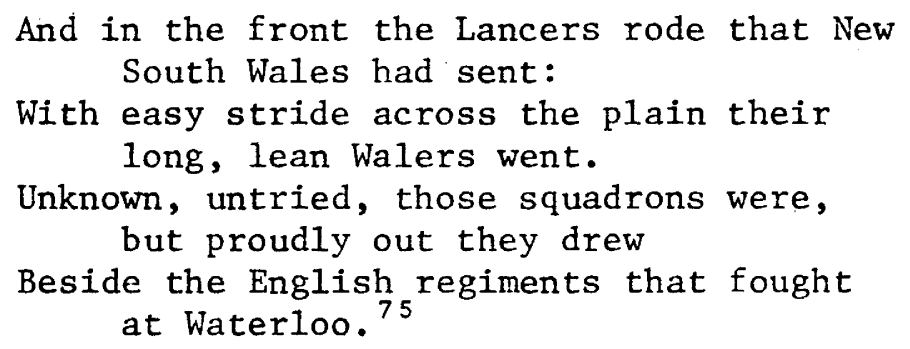

During the time that Lord Roberts had been gathering his invasion force together near Enslin, General Cronje with a force of 6,000 Boers had been sitting athwart the railway at Magersfontein in the belief that the activity to the south indicated the reinforcing of Methuen's shattered force and a renewed British advance on Kimberley. But French's sweep northwards and Roberts' easterly movement perplexed the old Transvaal general, and he decided to shift his force closer to Bloemfontein. On a bright moonlight night he passed unobserved just three miles to the north of the invasion army, earning for that force the opprobrium of The Times History which considered British scouting to be once again at fault. ${ }^{76}$ Roberts now set out in pursuit of Cronje, his plan being to halt him with his mounted men and then crush him with his infantry.

\footnotetext{
75 "With French to Kimberley", in Rio Grande and Other Verses, p. 6. 76 Vol. III, p. 402.
} 
The N.S.W.M.R. had missed out on the glamorous ride to Kimberley, but they were given the opportunity of a more demanding role as part of a force of 2,000 mounted infantry under Colonel Hannay, which tried to hold Cronje's commandos as they headed up the Modder river. However, the British force encountered stiff opposition from the Boer rear-guard and fell back before accurate light artillery fire, racing over a steep bank into the river in their confusion. "The incident was a signal object-lesson in the deficiences of the improvised force and of its leading", observed The Times Histomy. ${ }^{77}$ The reference was to the regular infantry who had recently been mounted, but the New South Wales men, deservedly or undeservedly, had to share in the odium of the retreat. Being brigaded with British regiments could bring acclaim, as the New South Wales Lancers had found when they rode along to Kimberley with French's cavalry. But there was another side to the coin, and the fine enthusiastic horsemen of the N.S.W.M.R. found this out when they were made a subordinate part of an inferior British mounted unit. Hannay's force was re-formed as best as possible and brought back into the attack, but again they "fell back in some confusion". ${ }^{78}$ Despite the shocking condition of French's horses after his dash to Kimberley, the cavalry were ordered into the race to head Cronje. The one day of operations involved in the relief of Kimberley had cost French only five men killed, but 68 chargers had died, mainly from exhaustion. ${ }^{79}$ The animals were to suffer even more the following day in the chase after Cronje, scores dying under their riders to become what were popularly known as "French's milestones".

The British cavalry succeeded in forcing Cronje to laager at Paardeberg Drift, thus recording one of the rare instances during the war

\footnotetext{
77 Vo1. III, p. 406.

78 ibid, p. 407.

79 Official History, Vol. II, p. 96.
} 
when a Boer force was out-manoeuvred by a far less mobile enemy. But the distinction was of dubious merit for Cronje had been slowed up by the presence in his convoy of numerous families which had joined the force while it waited at Magersfontein.

Paardeberg was the last major battle of the war. It was also the decisive battle of that conflict, but Australians played little part in the action. The Queenslanders had remained behind at Kimberley at the request of Colonel Ricardo who considered they were in need of a spell. For ten days the Q.M.I. men and horses enjoyed the comfort of the De Beers stables which Cecil Rhodes had made available to the Queensland commander. ${ }^{80}$ Those members of the N.S.W. Lancers whose horses were fit accompanied French from Kimberley but played no part in the battle of Paardeberg. The N.S.W.M.R. were more involved, being engaged with Colonel Hannay's force of mounted infantry in skirmishes on the periphery of the main Boer force, until Hannay received orders from Kitchener which implied the rushing of the laager. The charge was cut short, however, by the death of Hannay, who had ridden recklessly at the head of his men, probably smarting from Kitchener's criticism of the poor performance of his force during the preceding days.

From this point the battle became, of necessity, an infantry and artillery affair for horses were of little use against a besieged foe. of the colonial troops, it was the Canadians who won glory. They formed an infantry force of battalion strength which had been retained as a unit at the insistence of the Canadian government; and it was their turn to man the front line on the day of the final assault. They made the most of their opportunity, winning high praise from Roberts and from their prime minister, Laurier, who claimed that Paardeberg had revealed to the world that a new

80 Ricardo Papers, Letter to Arthur Ricardo, 28 February 1900. 
power had risen in the West.$^{81}$

It was after the final assault of Cronje's position by Canadian and regular infantry that Major Fiaschi of the N.S.W.A.M.C. figured in an incident that lent itself to exaggeration. While Fiaschi and members of his corps were recovering wounded Canadians close by the Boer lines, a group of 209 of the enemy displayed a white flag, filed out of their positions and offered their surrender to Fiaschi, the senior officer of the busy ambulance men. He accepted and his single-handed "capture" of a large force of Boers became one of the rare Australian legends of the South African War. At the same time as Fiaschi was supervising the stacking of Boer arms, General Cronje was surrendering his force of 4,000 men to Lord Roberts, and very soon the New South Wales medical men were in the Boer laager tending enemy wounded. ${ }^{82}$

Fiaschi had earlier won the attention of Roberts by asking to be excused from meeting the great man during an inspection of the Australian hospital. The doctor was busy operating. When news reached Roberts of Fiaschi's "capture" of the Boers, he recalled the incident and directed that the Australian be given a D.S.0. ${ }^{83}$

The efficient work of the New South Wales medical unit at Paardeberg was recognised by Roberts when, in eulogizing the Canadians, he referred to the New South Wales field hospital which was treating their wounded as one of the best-equipped he had seen arywhere in the world. ${ }^{84}$

Paardeberg was a notable engagement in a number of ways. It demonstrated some of the humane gestures between the combatants which earned

81 Colone1 C.P. Stacey, "Canada and the South African War", in Canadian Army e'ournal, Vol. 4, No. 4, 1950-1, p. 38.

82 Williams and Perkins, "The N.S.W. Army Medical Corps", in Barton, The Story of South Africa, p. 378.

83 Paterson, Happy Dispatches, p. 36. Fiaschi got his D.S.O.

84 Syiney Moming Herald, 2 April 1900, p. 8. 
for the conflict the title of "the last of the gentlemen's wars". During the siege the Boers would hold their fire while the British filled their waterbottles at sundown; British medical corps tended the Boer wounded both during and after the engagement; and when the dejected Cronje, portly and unkempt in a slouch hat and bottle-green overcoat, appeared before the trim and distinguished Roberts, the latter extended his hand and said: "I am glad to see you. You have made a gallant defence, sir". Whereupon the two men sat down to breakfast together, prior to the beginning of the long journey which was to end for Cronje and his men at St. Helena. ${ }^{85}$ For the Boers, Paardeberg was a humiliating defeat that was made worse by the fact that it took place on the anniversary of Majuba. It meant the capture of the most famous general in South Africa, along with 4,000 burghers, and the demoralisation of 14,000 others who were positioned on the periphery of the engagement and who now retreated in disorder towards the east. But it also meant the birth of new tactics; never again would the Boers attempt to hold a position against overwhelming odds, but would made use of their superior mobility to attack and withdraw. The capture of Cronje, along with the death of Joubert, who had commanded in Natal, also meant the eclipse of the old leaders and their replacement by younger and more able men like de la Rey and Christian De Wet. For the Empire, Paardeberg was a badly-needed victory which Roberts had successfully contrived on the anniversary of Majuba. Australian reaction was jubilant. There was wild cheering when the lieutenant-governor announced the surrender during the Sydney farewell to the third contingent, and the Primitive Methodist Conference at Goulburn rose and sang the Anthem when the news broke. In Adelaide the bells of the town hall rang out and sharebrokers, after a patriotic demonstration, sent a

85 David James, Lord Roberts, (London, 1954), p. 294. 
congratulatory cable to Roberts. ${ }^{86}$ The Wesleyan Conference in Melbourne responded with cheers and the Anthem, and in the New Southales Walcha the surrender was celebrated by a street procession which included "clergymen, aldermen and school children". The entire affair was suitably capped by Lord Milner who sent cables to the colonial governors congratulating them on the noble share of their troops in the surrender. ${ }^{87}$ An editorial in the Sydney Morning Herald the day after the report of Milner's cables called for a memorial to the event, and acclaimed the success of the Australian soldier on the "verdict of commanders like Lord Roberts and Major-General French, as well as the testimony of the Queen and her Ministers of Parliament and of the Press". ${ }^{8}$ The war was only young but the highly self-conscious nationalism of Australians had already begun to create a favourable image of itsmilitary representatives, principally from the courteous and calculated utterances of Imperial figures.

Paardeberg marked the end of a fruitful fortnight for the invasion force. Things had looked black for the British cause when Roberts left Enslin but now the tide was running Britain's way. Kimberley had been relieved, the main Boer army outside Natal had been captured or scattered, and Clements at Colesberg, Gatacre at Stormberg, and Buller in Natal all found their opponents melting away before them as the Boers moved to meet the greater threat. According to Conan Doyle, "a single master-mind had in an instant turned England's night to day". ${ }^{89}$ Small wonder that Australians considered it an honour to serve under such a man, and were thrilled to the core just to see the great "Bobs" ride by. 90

86 Sydney Moming Herazd, 1 March 1900, p. 8.

87 ibia, 2 March 1900 , p. 6.

88 p. 8.

89 The Great Boer War, p. 259.

90 Letters of Charles B. Holme, Letter of 8 April 1900; J.H.M. Abbott, Tommy Comstalk, (London, 1902), p. 194. 
In terms of numbers, the Australian colonies played a more significant role after Roberts moved on from Paardeberg, for most of the second contingent went up to join the main force as soon as they arrived in Cape Town. A reorganization of mounted infantry brought all units into four brigades commanded by four British colonels. Irregulars formed about half of each brigade, the idea being that the colonials with their scouting ability and better horsemanship would leaven the raw lump of improvised horsemen who had so recently been taken from the ranks of regular infantry. The first and second N.S.W.M.R. formed a half brigade, as did the first and second Q.M.I. and second contingent units from all other Australian colonies except Victoria. A squadron of Australian Horse and the Lancer squadron were brigaded with the regular cavalry. At this point, over 1,000 Australians were included in Roberts' force of $34,000 .^{9} 1$ But the men were to see very little action in the drive on Bloemfontein, for the defeat of Cronje had lowered Boer morale and shattered the loosely-knit Boer military organisation. An estimated 14,000 burghers streamed to the east in disarray. If French and his cavalry could have headed them and held them for the infantry divisions, the war may have been finished there and then. French's horses were too weary and under-nourished to effect an encirclement of the mobile enemy, however, and President Kruger was no more successful in getting the commandos to stand and fight. Therefore the engagement known as Poplar Grove amounted to no more than skirmishing between the Boer rearguard and the British cavalry.

The squadron of Australian Horse was accorded a considerable honour when the army moved out from Poplar Grove. They were sent ahead to find a ford over the Modder and to guide the main force across. Paterson

91 The Times Histom, Vol. III, pp. 494-5; Official Histom, Vol. II, p. 180 . 
stated that this might seem an casy task, but he claimed that the average "Tommy" could not have done the job. The assignment indicated that Australians had already won recognition for their scouting ability. 92

The burghers did make a stand at Driefontein, however, despite continuing desertions. Kruger and General Christian De Wet were influential in getting the Boers to make a fight of it, but the decisive factor was General J. de la Rey, who had cut short his successful campaigning in the Colesberg area to hasten back with a small force to oppose Roberts. No more than 7,000 Boers faced Roberts at Driefontein, but the British suffered sharp casualties in an unsuccessful attempt to contain them. The Official History notes some Australian participation in the battle. The two squadrons of cavalry from New South Wales were among the units used by French in an attempt to turn the Boer flank, and when the enemy had been forced into retreat by the British infantry they joined in a pursuit rendered fruitless by tired horses. The mounted infantry brigade that included the Queenslanders was engaged in holding an outlying kopje throughout the day. Once again it was the infantry which bore the brunt of the fight. Out of 87 killed and 347 wounded only 17 wounded were not infantrymen. 93

The Australians received a favourable press despite their modest contribution to the battle. The London cables read: "The New South Wales Infantry (sic) did splendid service" and "The New South Wales Mounted Infantry Regiment made a gallant attempt to capture the Boer guns". There were no details to spoil the favourable impression the public would have gained. ${ }^{94}$

There was no further opposition before Bloemfontein and on 13 March, just 30 days after he had set his invasion force in motion, Roberts entered the capital city of the Orange Free State. In that short time the war had

92 Sydney Morming Herazd, 20 March 1900, p. 5.

93 Vol. II, pp. 221, 224.

94 Sydney Morning Heral.d, 13 March 1900, p. 7. 
wung dramatically in Britain's favour. The Official History attributed he change to the strategy of Roberts and the confidence the troops had in heir leader; and to two additional infantry divisions and the "assistance of he Colonial contingents". 95

The Australians had sustained minimal casulties in their first honth with Roberts, 96 but they and their horses had undergone severe physical lardship. The horses in particular, had suffered. For weeks they had survived on a half-ration of two and a half pounds of oats a day and what lerbage they could find on the parched veldt. This lacked nutrition, being equated by an Australian officer to Bryant and May's matches. ${ }^{97}$ To make the situation worse, the Australians' horses were given no acclimatisation period in South Africa. The mounts of the greater part of the second contingent had joined Roberts' column twelve days after disembarkation, three ff which were spent on a train. ${ }^{98}$ Within a month of landing only 50 horses put of the 2nd Q.M.I. total of 170 were still with the unit. 99 The rest were lead from exhaustion or sickness, or were recuperating in depots run by the Remount Department of the British Army, from whence they were allocated as remounts to any British or colonial unit. Few would have found their way pack to Australian units. None of them returned to Australia because of quarantine regulations. So the 40,000 horses that went to the war from Australia, either with the contingents or as remounts, were destined for leath, usually an early and cruel death on the uncomforting veldt. ?aterson, the horse-lover, spoke with feeling of their plight in a poem falled "The Last Parade", in which he described their privations and imagined

95 Vol. II, p. 239.

96 The 1st N.S.W.M.R., for example, lost only one man killed and 12 wounded.Letters of Major A.A. McLean, D.S.O. (Sydney, 1931), p.31.

97 Ricardo Papers, Letter to Arthur Ricardo, 6 February 1900.

38 Diary of W.A. Steel, p.27.

39 Letters of Charles B. Holme, Letter of 22 March 1900. 
them pleading to be returned to their native land -

Home to the Hunter River,

To the flats where the lucerne grows;

Home where the Murrumbidgee

Runs white with the melted snows. 100

Close by the entrance to the Sydney Botanical Gardens there is a plaque honouring the Australian horses of World War I. Perhaps in some hidden corner of an Australian city there is a memorial to the greater-suffering horses of the South African War.101

Australian soldiers were better able to endure the privations of the drive on Bloemfontein than their horses. Despite reduced rations (the result of the inability of the transports to keep up with the movement), heat, violent thunderstorms, and no shelter of any kind, the Australians displayed a fortitude and a capacity to "make do" that won praise from Paterson. The Australian war correspondent regarded them as quite different from the English, "in that they were always providing for their own wants in mysterious ways". The night after Driefontein, the troops got into their bivouacs in darkness. Units were all mixed up but Paterson came across two Lancers with a couple of ducks and sufficient firewood (a scarce commodity) to cook them. They soon made themselves comfortable for the night, not worrying in the least about being separated from their squadron. "This capacity to shift for themselves", noted Paterson, "has been a great feature of our troops all along the march". 102

100 Rio Grande and Other Verses, p.156.

101 Equine losses in the South African campaign were appalling. A total of 518,794 horses went into service with the British forces, and of these 347,007 were expended during the war. - Elgin Commission, Vol. 42, p. 258 . The Boers were superior horsemasters and their ponies were more durable than imported horseflesh, but it would be reasonable to estimate that the fully mounted armies of the two republics lost enough horses to bring the total of expended animals to about half a million.

102 Sydney Morning Herald, 21 April 1900. p.10. 
Roberts was compelled to stay in Bloemfontein for seven weeks to rest his men and horses, to await remounts and supplies of clothing, and to secure the railways. It is unfortunate that he had to delay his advance for Bloemfontein, the "fountain of flowers", belied its name and became a pest-hole of enteric fever and other illnesses. The unclean water at Paardeberg, polluted by dead horses and human waste from Cronje's laager, had infected the army and the disease had completed its incubation stage at the time of entry into the capital.103 Conan Doyle regarded the epidemic as "the greatest misfortune of the campaign",104 and an Australian reporter wrote feelingly of a tragic episode which cost more than 1,000 1ives.

There is no forgetting the carts that rumbled through the street, loaded with those stiff, blanket-shrouded shapes which had been vigorous men - the dwindling squadrons, the crowded sick tents, the unfed, unwashed, unhappy men who filled them, will never cease to linger in one's memory. 105

Initially, the medical facilities to cope with the outbreak of enteric were inadequate, but the inadequacies served to increase the value of the contribution of the N.S.W.A.M.C. The second medical unit had arrived in South Africa in February, and had joined Gatacre in his advance from Cape Colony to Bloemfontein. Fourteen nursing sisters had sailed with this draft. Both medical contingents now came together to form a well-trained, we11 equipped corps of about 240 personne1, with an immediate task of tending to the sick at Bloemfontein. 106

103 Enteric was endemic to South Africa and it reached epidemic proportions through concentrations of men in conditions of poor sanitation. Flies carried the germ from open latrines; faeces deposited near river banks were washed into the stream; and pulverised excreta and dried urine became windborne. Boiling of water was essential but impracticable because of the time factor and scarcity of fuel.

104 The Great Boer War, p.279.

105 Abbott, Tommy Cornstalk, p.140.

106 Williams and Perkins, "The N.S.W. Army Medical Corps", in Barton, The Story of South Africa, pp. 371-4. 
Colonel Williams took over the Free State Artillery barracks and Jon had an efficient hospital functioning. In the early weeks of the pidemic, the sick lay on the floor in their clothes with one blanket to cover hem and little more than Bovril and tinned meat for food. An "all pervading pecal (sic) odour" so filled the make-shift wards that it was considered pessary to divert to other hospitals the wounded brought in by New South ales ambulance men from skirmishing on the outskirts of the town.107 Imission to the N.S.W.A.M.C. hospital was never limited to Australians. The ict that the sick and wounded from any regiment were taken in if space was railable was regarded by an Australian war correspondent as something that istinguished the colonial medical corps from the Imperial.108

At Bloemfontein and in the field, prior to the onset of the epidemic d after, the N.S.W. hospital won a reputation that had a legendary quality. was claimed that "Tommies went about with tickets sewn into their tunics faring the words 'If sick or wounded, please take me to the N.S.W. Hospital' ".109 Lancer noted, "They have a splendid name here, and Lord Roberts sends his punded officers to them in preference to the English Corps". 110 Others wrote similar vein. 111

General E.T.H. Hutton, former New South Wales commandant, directed s praise to the New South Wales premier in a message which stated, "Their aises are in everybody's mouth, and I am told that every sick and wounded ldier ... hopes that Providence may place him under the care of the N.S.W. bulance". 112 In drawing attention to the ambulance function, Hutton was

7. R, Scot Skirving, "Our Army in South Africa", National Library Famphlets, Vo1. 185, No.3589, p.24.

8 Wilkinson, Australia at the Front, p.100.

9 ibid, p.98.

Barton, The Story of South Africa, p.159.

See Diary of W.A. Steel, p. 114; Report of Lieut.-Colonel M.W. Bayley, A.W.M. Wilkinson, Australia at the Frort, p.140. 
referring to the outstanding section of the New South Wales medical unit. The Principal Medical officer of the British Army in South Africa, in his evidence before the Elgin Commission, freely recognised the superiority of the New South Wales ambulances, He attributed this to the fact that the colonial unit had its own transport and was not reliant on the army transport pool as the Imperial ambulance units were. The F.M.O. praised the efficiency of the Australian medical officers but said, "Their transport was the thing for us to imitate".113 Colonel Williams explained the superiority of his ambulances in an interview given on his return from South Africa. He dismissed rumours that the Imperial medical corps was to be re-modelled on the N.S.W.A.M.C. and said that what distinction was claimed for his corps was due to a light and mobile waggon service which was an integral part of the unit. In treatment, organisation, and other equipment, the colonial and Imperial corps were identical. When in the Soudan with the New South Wales contingent, Williams had noticed the shortcomings of the Imperial system, and had effected the appropriate modifications for the N.S.W.A.M.C. 114

It is difficult, however, not to see Williams as the factor which won for the medical unit pre-eminence among the many Australian corps sent to the South African War. He had raised the unit and brought it to a high standard of efficiency, and the superior quality of his leadership soon became obvious in South Africa. In quick succession he held the post of P.M.0. for the Australian and New Zealand forces (the first Anzac command, surely), for General Ian Hamilton's mounted infantry division, and finally for Sir Archibald Hunter's force of 35,000 , an appointment which Williams claimed as the largest medical command of the campaign. 115

\footnotetext{
113 Vo1. $42, \mathrm{p} .158$

114 Sydney Moming Herald, 7 January 1901, p.7.

115 ibid,
} 
When a medical force was raised to accompany the Australian

Commonwealth Horse to South Africa, Lord Kitchener asked that Williams should accompany the unit. But he was needed at home to develop the medical forces of the new nation. As with many other Australian officers, Williams was eager to serve and to serve well in the campaign, for in addition to being a patriot who wished to win an identity for his country, 116 he held a higher loyalty. Amid the death and hardship of Bloemfontein, Williams was able to report to his commandant in New South Wales:

We know nothing of what is going on in the outside world, nor even in our own immediate neighbourhood - but one and all work on, sternly and quietly $\ldots$ having in view only one object the Empire. 117

The occupation of Bloemfontein brought considerable numbers of

Australians into close contact with Imperial troops for the first time in history, and the comparisons drawn by Paterson favoured the colonials, whom he described as "long-legged young fellows, brown and hard-faced, and all with the alert wide-awake look that distinguishes the Australian soldier from the more stolid English 'Tommy' ".118 Paterson was also impressed by their keenness to involve themselves in the skirmishing that was going on around the town. On one occasion he met fifty de-horsed members of the N.S.W.M.R. who were walking to an engagement fifteen miles north of Bloemfontein in the hope of getting into action. ${ }^{119}$ The bulk of that regiment did see service in this area, however,

116 When Colonel Hoad was commanding the Australian Regiment at Enslin, Williams approached him with a suggestion that the men wear an "Australia" badge on the shoulder strap. The idea was widely taken up.- See Reports of Colone1 W.D.C. Williams to G.O.C. New South Wales, A.W.M., Report of 7 January 1900.

117 ibid, Report of 4 April 1900.

118 Sydney Morning Herazd, 9 May 1900, p.7.

119 ibi.d, 10 May 1900, p.8. 
and returned to Bloemfontein after a month's patrolling to the north, with their ranks greatly depleted through enteric and dysentery and their horses in ghastly condition. By contrast, Ricardo's Q.M.I. experienced only one sharp engagement which added nothing to the lustre of Australian arms. East of Bloemfontein, Christian De Wet had rallied sufficient burghers to take the initiative from Roberts' immobilized army, and at Sannah's Post inflicted a stinging defeat on General Broadwood's column. The Q.M.I. and Imperial units went to Broadwood's aid, but were forced to retreat after being pinned down for four hours. Ricardo comforted himself by blaming the entire affair on poor British scouting, and tried to dissociate the Queenslanders from the defeat by holding to a rumour that Roberts was to mention the unit in his dispatches. 120

It was not until the end of May that De Wet's depredations on the British supply lines were brought to a temporary halt and arrangements were completed for the march on Pretoria. Of great importance to Australians was the creation of a mounted infantry division. There had been some talk of an Australian mounted infantry brigade, "but it had not amounted to much, because of the intercolonial jealousies among our officers".121 The two New South Wales cavalry squadrons were motivated to resist inclusion in an Australian division by other factors. Although the distinction between cavalry and mounted infantry had largely vanished, the men of the New South Wales Lancers and the Australian Horse considered there was "a certain amount of

120 Ricardo Papers, Letter to Ralph Ricardo, 5 May 1900.

121 Wilkinson, Australia at the Front, p.106. The same writer also stated that the lack of an Australian officer of sufficiently high rank to command was another reason for no Australian brigade being formed.p. 241 . 
eclat in being brigaded with troops like the Scots Greys or Inniskillings."122 So the Australians remained part of French's elite cavalry division, the only colonial troops to be so honoured. The mounted infantry division of two brigades was formed under General Ian Hamilton, with General E.T.H. Hutton and Colonel C.P. Ridley as brigadiers. Hutton's command comprised all the Australians, the Canadians, the New Zealanders, and four battalions of regular mounted infantry. The Australians numbered 2,000 in a force of just on 6,000, and the pioneer company and medical corps were Australian units. Four of Hutton's eight staff officers were Australians. 123 With a 1arge "A" sewn on the left side of their helmets to emphasise their identity, and being dominant numerically in three of Hutton's four corps, the Australians were for the first time in a position to make an impact as a national force. But the opportunities for military achievement were quickly diminishing. The Boers were no longer prepared to fight the pitched battles that created heroes and, in any case, the mounted infantry were to continue to play a subordinate role to the cavalry until the tedious and unheroic guerrilla phase of the war began. Hutton was delighted to have the Australians in his command. "Such fine looking workmanlike men", he called them, 124 and he had high hopes for them and for the other colonials in his brigade. Hutton considered the men from Canada and Australasia as representative of all that was best in "the young and vigorous manhood" of the colonies. He wanted them to win prestige for their colonies through military success but considered they were "ignorant of their own value."125

On 3 May, with bands playing, Roberts led his army out of the

122 Sydney Morning Herald, 11 May 1900, p.6.

12.3 Official History, Vo1. III, p.528.

124 General Hutton's Letters to His Wife, A.N.L., Vol. I, Letter VI, 2 April 1900.

125 ibid, Letter VII, Pp.26-7. 
pestilential city. His command actually extended through a series of British forces reaching from Kimberley to Ladysmith, and now this Imperial host of 110,000 men made independent but converging progress towards Pretoria. On the right wing was Buller, moving his force of 45,000 out of Natal with irritating slowness. On the left were Hunter and Methuen with 20,000 men, and in the centre was the main strike force of 44,000 men, including 2,500 Australians. Confronting the British advance was an estimated force of 30,000 Boers, who were in a state of utter disarray. 126 In the words of Conan Doyle, the record of the army's progress from Bloemfontein to Pretoria was"rather geographical rather than military,"127 but occasionally the enemy made a tentative stand and in the ensuing skirmishes Australians usually played a part.

The spirits of Hutton's colonials were high as the force moved northward, for the anticipated capture of Pretoria was regarded as the conclusive and crowning achievement of the war, and the mounted infantry were appointed to play an important part in the operation. One historian honoured the Australians with the title of "the eyes and the ears of the army of invasion,"128 and they did play a significant part in the advance, forming protective screens for artillery, infantry, and supply columns. By day they patrolled far ahead of the slower and more vulnerable corps and closed in to the main force at night. So essential was this scouting function that Hutton's force soon became widely dispersed, the N.S.W.M.R. and W.A.M.I. even passing under the direct control of Ian Hamilton at Kroonstadt.129

\section{The Times History, Vo1. IV, pp.86,95.}

127 The Great Boer War, p. 321.

128 Donald Macdonald "A History of the Australian Contingents in the South African War," in Harding, War in South Africa, p.634.

12.9 Wilkinson, Australia at the Front, p.156. 
Yet despite their importance, Hutton's men were obliged to play a subordinate roie to the cavalry. The mounted infantry brigade operating under Ian Hamilton had relative freedom of movement and operated with effect on the right wing of the advance, but Hutton's brigade was operating with and under French and he would not permit the mounted infantry to advance in front of the cavalry, much to the chagrin of Hutton. 130

The mounted infantry did not always operate in the shadow of the cavalry, however, and on the occasion of the first Australian skirmish in the advance northwards the cavalry were conspicuously absent. At Karee Kloof, out from Bloemfontein, 300 Victorians under Colonel Tom Price were detailed to lure a Boer force from a series of kopjes for destruction by the artillery and cavalry. But the Boers were concealed in long grass on a plain and very successfully ambushed the Victorians and a company of Cornwall mounted infantry, chasing them over two and a half miles of flat country. The dreaded pom-poms ${ }^{131}$ were also brought into use, causing death and panic among the horses, and it was in this situation that the Victorians partly redeemed themselves by carrying to safety de-horsed comrades. Amid the confused retreat a message was received advising Price to delay the operation for two hours to permit the cavalry to come up! Victorian casualties were light: three prisoners taken and one man injured by a fall from his horse, and Victorian achievement was nil, but Price was able to convey to his discomfited men the praise of the divisional general for "the masterly and soldier-like retreat" they had made. ${ }^{132}$ An Australian historian blamed the debacle on poor Imperial leadership

130 On one occasion, Hutton sent his Canadians across a bridge over the Klip river to take a ridge and thus secure the crossing for the rest of the brigade, but French came up and made the Canadians wait twenty minutes while the cavalry moved ahead of them.- Hutton Letters, Vol. II. Letter XXI, 2 June 1900.

131 Rapid-firing artillery which used one-pound shells.

132. Barton, The Story of South Africa, pp.249-252. 
and tactics, ${ }^{133}$ but a Victorian trooper who took part in the "engagement" attributed the rout to poor scouting by the V.M.R. 134

By contrast, the next skirmish involving Australians brought great credit to the men of the N.S.W.M.R. On Sunday, 5 May, ${ }^{135}$ Hutton's force attacked Boer positions at Coetzee's Drift on the Vet river in what was to be the only engagement in which the colonial brigade operated as a unit. The enemy, numbering an estimated 1,000, were positioned along the right bank of the river with their artillery covering them from a kopje beyond. The Royal Horse Artillery softened up both positions, and then Hutton sent in the N.S.W.M.R. The Official History gives a glowing account of the work of the men from New South Wales:

They delivered their attack with determination, rushing the drift despite heavy fire and lack of cover ... Nor did the New South Wales men stop at the northern bank, but pushed the enemy at the point of the bayonet, not only from the Vet river, but headlong over a spruit which offered a second sunken position to their riflemen. 136

Later in the day, after an artillery bombardment, the kopje was cleared of Boers by a composite force of Queenslanders, New Zealanders, regular mounted infantry, and the men from New South Wales.

Roberts was highly delighted at the result of the operation and congratulated the mounted infantry on "their fine day's work". 137 The men of the N.S.W.M.R. were elated $;^{138}$ and Hutton's joy was boundless. He was particularly

133 ibid, p.249.

134 A.E. Satchwe11, On Active Service (Camperdown, n.d.) p.67.

135 The Boers generally were loath to fight on the Sabbath.

136 Vo1. III, p. 48 .

137 ibid, p.49.

138 Diary of W.A. Steel, p.83. 
proud of the men he had used as shock troops for was he not their honorary colonel? And had he not laid the foundations of their efficiency when military commandant of New South Wales? "Your fellows are terrors to fight," he told their commanding officer, ${ }^{139}$ and in a more private moment he sought from the Almighty "the discrimination and the insight to know when and how to best utilize such grand material". ${ }^{140}$ The only casualties suffered by Hutton's force were four men wounded (none from New South Wales). This was attributed to the Boers' being disconcerted by the vigour of the attack, and to inaccurate artillery fire and defective shells. ${ }^{141}$

The line of the Zand river gave promise of being the location for a major battle, for Kruger and Steyn had agreed to make a stand. But although the engagement was the most important in the drive on Pretoria, it could not be dignified with the name of battle. Had the British forces made a frontal attack on the Boer positions, the Zand river could have been another Colenso or Magersfontein. However, the lessons had been learned, and the British strategy was a pincer movement, with French's cavalry moving in on one of the enemy's flanks and Bruce Hamilton's infantry on the other. Afraid as always of being encircled, the Boers retreated and offered no further significant resistance until after Roberts had entered Pretoria. During French's flanking movement, disaster befell a section of his force through poor scouting. Three squadrons drawn from the Australian Horse, the Inniskillings, and the Scots Greys were ordered to silence a Boer artillery position, but were ambushed by a force of enemy horsemen whom they had assumed to

139 Sydney Moming Herazd, 21 June 1900, p.8.

140 Hutton Letters, Vol. I, Letter XVI, 9 May 1900.

141 ikid, Letter XV, 6 May 1900. 
be British mounted infantry. The cavalry detachment took shelter in a nearby cattle kraal until forced by the Boers into wild retreat. Many horses were killed in the engagement, and many more stampeded. British casualties were high although no determined stand had been made: 14 killed, 36 wounded and 27 taken prisoner. No Australians were killed but 21 of their 35 horses were. The "Kaalong disaster" brought no creditto the Australian Horse. 142 The other Australian cavalry squadron, the New South Wales Lancers, did make amends, however, when the cavalry division was moving through Kalkhevvel Pass later in the advance. The 6th Dragoons, who were leading the division, were ambushed and began a mad gallop towards the rear. The Inniskillings and New South Wales Lancers, next in line of march, were almost overwhelmed in the retreat, but they responded to a call from Major Allenby to stand fast. Their example rallied the disorganised squadrons and imminent panic was averted.143

The irresistible British legions rolled on, taking Johannesburg and Pretoria with ease. Yet Roberts' achievement was illusory, for the Boers had been virtually untouched by the British advance. ${ }^{144}$ On the other hand, the loose military organisation of the Boers had failed completely. The future of the war effort of the two republics seemed to rest with independent commandos using guerrilla tactics and led by enterprising leaders like Christian De Wet. This

142 The Times History, Vo1. IV, P.118; Letters of Trooper H.L. Harnett, A.W.M., Letter to father, 13 June 1900.

143 J. Watkins Yardley, With the Inniskizlings Dragoons (London, 1904), p.88. After Bloemfontein the Lancers formed a distinct squadron of the Inniskillings.They were commanded by Allenby of the Inniskillings, who was to become one of the great leaders of World War I.

144 The Times History compared the progress of Roberts' army with the progress of a man-of-war, the Boer forces parting like the waves of the sea but gathering again as the hosts moved on. - Vol. IV, p.159. 
type of warfare had already been practised against Roberts' eastern flank as he moved on Pretoria, and it was to become the pattern. Roberts was confident that the war had been won when he entered the Transvaal capital. In reality, he had only determined its character for the next two years.

British battle losses were understandably light on that great drive; Hutton's brigade, for example, lost only one man killed and thirty-five wounded. ${ }^{45}$ But another type of casualty, the de-horsed mounted soldier occurred in numbers that rivalled sickness and disease as the scourge of the army. Roberts had covered the 300 miles from Bloemfontein in five weeks. But his horsemen had travelled much further than that on reconnaissance and screen duties. The result was that three of the four cavalry brigades lost 30,40 and 60 percent of their strength respectively. The mounted infantry lost 18 percent of a comparable number. ${ }^{146}$

Australian losses were so high through illness and horse wastage that after Pretoria the components of the first and second contingents almost ceased to exist as viable units. The Queenslanders, in particular, suffered. Colonel Ricardo claimed that of the original 520 men of his command, only 192 got to Pretoria, the rest being either wounded or invalided. ${ }^{147}$ A trooper wrote that only 40 men of the 1 st and 2 nd Q.M.I. reached Pretoria, and of these only 15 had horses in a fit state to go on. "Lots of our men are sick," he noted,"some gone home to England and Queensland, some left behind on duty and crowds of poor beggars walking, having no horses."148 The active strength of the Q.M.I. was further reduced by British recruitment for police and railway duties. A question in the Queensland Legislative Assembly regarding the

\footnotetext{
145 Hutton Letters, Vo1. II, Letter XXIII, 6 June 1900.

146 The Times History, Vol. IV, p. 162.

147 Ricardo Papers, Letter to Ralph Ricardo, 20 June 1900.

148 Letters of Charles B. Holme, Letter of 12 June 1900.
} 
decimation of the Q.M.I. elicited no concerned response from the premier, 149 and by the time the military commandant wrote his report for 1900 he could state that the first and second Queensland contingents had practically ceased to exist "as such". A "large number" of men had succumbed to enteric and "upwards of 100" had accepted employment on police and railway duty. 150

The N.S.W.M.R. losses were also considerable. An officer of the unit claimed shortly after the fall of Pretoria that the regiment could only parade 80 men out of 600. Some, he said, were dead, some sick and wounded, and "othersscattered generally over South Africa". ${ }^{151}$ When allowances are made for the cracking pace set by Roberts, the phenomenon of de-horsed troopers might be explained in terms of poor horses or poor horsemastership. And evidence before the Elgin Commission suggested that Australia was guilty on both counts. A British expert rated Australian horses as "very bad", although on the grounds of their not being acclimatised, a process which took up to nine months. ${ }^{152}$ Many Australian horses had been wasted by Bloemfontein, however, and big sectionsof the first and second contingents had been re-mounted for the drive on Pretoria. Many of these remounts were also unsatisfactory, particularly those imported from the Argentine. The Q.M.I. were supplied with this breed before heading north, and their horse losses were extremely high. It was General John French himself who rated over-sea colonials as "good horsemen, but bad horsemasters" and he cited the squadron of Australian Horse as an example. In its first three weeks of duty with the cavalry brigade, the squadron (about 100 horses) was reduced to only 10 horses fit for duty, while in the same period the Scots Greys, with whom

149 Q.P.D., Vo1. LXXXIV, p. 386.

150 Queensland Defence Force: Reports of Commandant, 1877-1900, A.W.M., Report of 1900, p. 9.

151 Letters of Major A.A. McLean, p. 50, The scattering was invariably caused by troopers being de-horsed and falling behind their units. 
they were brigaded, were reduced to about 30 horses per squadron. ${ }^{153}$ Campaign conditions which wrought such havoc on man and beast must have been extremely rigorous. It is fortunate that Trooper Steel of the N.S.W.M.R., an intelligent and perceptive diarist, should have written a full account of conditions in the field. Hardship was a constant. Steel noted that up to the time he was hospitalised at Johannesburg through a fall from his horse, he had slept always on the ground and beneath the stars, had never been completely undressed, and had never been free from vermin. When the force reached the Valsche river, Steel had been without a wash for twelve days and had not changed any item of clothing. But there he indulged in ablutions with 2,000 other Australians and Canadians, using sand and gravel in place of soap. Along. the banks, Tommies, with their legendary aversion to water, played cards and watched the frolic. ${ }^{154}$ Lice were a major problem, and their eradication from the person was a continuing task. One novel method was to remove the clothing and place it on an ants' nest where the ants devoured the lesser insects, but Colonel Tom Price urged calm acceptance of the nuisance. Addressing the V.M.R., he said, "Why ... I'm lousy, the Padre's lousy, Lord Roberts is lousy, and the dear old Queen would be lousy too if she were here". 155

Inadequate food for both man and beast greatly hampered the efficiency of Roberts' army. The full daily ration for troops was four biscuits, a tin of bully beef, and a small quantity of coffee or tea, but frequently on the march to Pretoria this was reduced to two biscuits and little or no meat. Quite often the biscuits were consumed with the aid of water only because

153 ibid, p. 301 .

154. Diary, pp. 96, 105.

155 Alured Kelly "Personal Account", p.6. It was claimed that Madam Melba's brother was sent home as "unsuitable" because he lost heart as soon as he found he was lousy. - Diary of Sgt. Robert Hodgson, 2nd Scottish Horse, A.W.M., no page or date identification. 
firewood was so scarce. ${ }^{156}$ Under such unsatisfactory commissariat conditions the urge to live off the land was great, and led to what was euphemistically known as "commandeering". Farmhouses were searched for chickens, eggs, vegetables, stock and horse fodder. It was not an unusual sight to see a trooper ride into bivouac with sheaves of hay strapped to his saddle, a fence post balanced across the pommel, a chicken attached to his person, and the horse's nose-bag full of eggs. Steel reported that from farms showing no signs of belligerency, soldiers took what they wanted but left receipts for the items; where ammunition was found or males were thought to have recently been under arms, goods were taken without receipt; and where farmhouses were in areas of active belligerency, the buildings were burned. ${ }^{157}$ Conan Doyle painted an idealised picture of Tommies living on foul water and bully beef while tramping through a land of fat geese and other abundance which they dare not touch because of Roberts' stern attitude towards looting. ${ }^{158}$ But there can be no doubt that the practice was widespread. Paterson stated that it was generally accepted that to acquire sustenance for man and horse was no crime, ${ }^{159}$ but unfortunately, looting did not stop at the essentials. Australians became particularly adept at the art. ${ }^{160}$ When the N.S.W.M.R. reached Pretoria, they were informed by their commanding officer that they faced banishment to the line of communication if British authorities received any more complaints over looting. ${ }^{161}$

156 The biscuits were highly nutritious but extremely hard. They were called "forty-niners" after the number of perforations they bore. "Forty-niners" were sometimes fed to the starving horses of the Australian Regiment as it advanced to Bloemfontein, with hideous aural results. - Reay, Australians in War, p. 319.

157 Diary, pp. 83, 92.

158 The Great Boer War, p. 325.

159 Sydney Morning Herald, 20 April 1900, p. 5.

160 "What a multitude of sins that word [commandeering] covers!" wrote one of them. "What we call at home thieving, looting, burglary, and horsestealing, is all called commandeering here, and is very much in fashion". - Diary of W.H. Barham, Letter to wife, 19 May 1900. 
If there was hardship on that 300 mile drive, there was also spectacle sufficient to thrill the citizen soldier of the Empire. What could have been more exciting than to form part of a great British army as it prepared to move over the Zand river, and against the assembled Boer remnant, in what would have been the last battle of the war had the enemy stood his ground. Then there was the vast veldt, a pall of smoke by day and a sea of flame at night as the Boers used the fire stick to impede the progress of their pursuers, and to create a landscape that acted as a foil to the hitherto camouflaged khaki figures. The sweep into Johannesburg with its gum trees and wattles - the place where it had all begun - was exhilirating; and so was Roberts' grand review of his army in Pretoria. But perhaps the greatest spectacle of all occurred on the night of the 24 May as the army prepared to cross the Vaal river. During the evening there had been singing around the camp fires, and then on the order "lights out!" regiment after regiment sang the national anthem. Steel estimated that 40,000 men would have joined in "the homage of the fighting Army on the last birthday of Queen Victoria".162 The capture of Pretoria did not end the war, and in the months that were to pass before they completed twelve months service and were allowed to return home, the men of the first and second contingents played various parts in a conflict that no longer merited the name of "the last of the gentlemen's wars". There was an occasional good scrap, as at Diamond Hill; there were exciting horse-killing "hunts" after the elusive De Wet; and there were lazy days in the saddle while acting as escorts to supply columns; but for the most part the Australians found themselves involved in the unsavoury duties connected with what was termed "pacification" or "police duty".

While the army was still at Pretoria, some corps fought an engagement against a determined force of 5,000 Boers led by General Louis Botha. The location was Diamond Hill on the Magaliesberg, a few miles to the east of Pretoria, 
and General Jan Smuts was to regard the fight as the last great defensive battle fought by the Boers. ${ }^{163}$ Against Botha, Roberts sent 14,000 men and a strong artillery force. In the middle advanced the infantry, and on the left and right flanks respectively were the sadly depleted ranks of Ian Hamilton's mounted infantry and French's cavalry. The latter force included 10 men of the Australian Horse and 35 of the New South Wales Lancers - all that were left of two squadrons! French, moving against the enemy, sent a troop of Lancers ahead as scouts, but they were shelled by British artillery who thought the Australians were Boers joining their comrades. Luckily no-one was hit, but French soon faltered and waited for the infantry to come up and take the position. 164

On the other flank, the mounted infantry were doing much better. The N.S.W.M.R. in particular were in the process of winning further distinction. Ian Hamilton had come up against a heavily defended Boer position on Rhenosterfontein kopje, against which he directed Colonel De Lisle's force of 6th M.I., N.S.W.M.R., and W.A.M.I. De Lisle, after softening up the enemy with two pom-poms, ordered the 6 th M.I. to dismount and work up the hill. The N.S.W.M.R. were sent as support troops and the W.A.M.I. were held in reserve. As soon as De Lisle saw that the British regulars had gained a footing on the hill, he let loose the men from New South Wales. They stormed onward in open order and against brisk fire, fighting their way up the steep hill and bursting over the crest with fixed bayonets. But there

163 W.K. Han fock and Jean Van Der Poel (eds.) Selections from the Smuts Papers (Cambridge, 1966), Vo1. I, P.557.

164 Sydney Morning Herald, 28 July 1900, p.11. This was not the first occasion when Australians were mistaken for Boers. Paterson reported that it was a common occurrence in the Colesburg area, where the Lancers were once fired on by the 6th Dragoons. - Sydney Moming Herald, 29 January 1900, p.8. But it was a London report that the Q.M.I. had been about to fire on the V.M.R. that led the New South Wales commandant to issue the second contingent with hastily and poorly manufactured helmets instead of slouch hats. French soon regretted his haste and the third and subsequent New South Wales contingents reverted to hats. - N.S.W. V. \& P. Vol. 4, Select Committee on the Administration of the Military Department, Minutes of Evidence, p.40. 
was none of the hand-to-hand fighting that the Australians always loved to contemplate, for the Boers had retreated from the kopje. De Lisle's men had in fact captured the key to Botha's position, for the way was now clear for Ian Hamilton to bring his artillery on to Diamond Hill plateau, from whence he could shell the Boers at all points. Hearing of De Lisle's success, Botha withdrew his force. 165

The courage and dash of the men of the N.S.W.M.R. was reminiscent of the Vet river engagement, and it pointed forward to Gallipoli and Flanders. But it was yet another occasion when Australian officers displayed a tragic recklessness. As the men crawled forward on their stomachs up the hill, Lieuts. Harriot and Drage stood up and urged the troopers forward by name. In foolhardy defiance, they even stopped to fill their pipes although their men implored them to take cover. Both men were soon struck by bullets. Drage was shot through the head, but it took four troopers to restrain the dying man from stumbling forward against the Boer position. Both officers died, and two troopers also paid the supreme sacrifice. ${ }^{166}$ De Lisle's corps was complimented by Roberts and Ian Hamilton and De Lisle was himself ecstatic over the work of the N.S.W.M.R. ${ }^{167}$ When General Ridley paraded the corps in recognition of their fight, the Gordon Mounted Infantry sought and gained permission to give the New South Wales men three cheers. 168

After Pretoria, Roberts had two objectives in mind. He wanted to complete the crushing of the Transval by a drive along the Pretoria-Delagoa Bay railway to Komati Poort, a town on the Portuguese East African border.

\footnotetext{
165 The Times History, Vo1. IV pp. 289, 292.

166 Sydiney Morning Herald, 28 July 1900, p. 11.

167 Wilkinson, Australia at the Front, p. 199.

168 Diary of W.H. Barham, Entry of 14 June 1900.
} 
This would rid him of the temporary seat of Boer government at Machadodorp, and the army of Louis Botha. And he wanted to crush Free State opposition which, inspired by President Steyn and Christian De Wet, was threatening his supplies and communications. He gave scant consideration to enemy activity in the western Transvaal, where a new breed of Australian soldier, the Bushman, was making his presence felt.

The drive to Middleburg passed with little event, as Botha was prepared to risk rear-guard skirmishes only, and French had been instructed by Roberts to avoid blood-shed wherever possible. At that point, Roberts broke off his advance to send nine columns fruitlessly chasing after De Wet for a month. In late August, the drive began again. Roberts had been joined by Buller's Natal army, and September found Buller and French forming the wings of a fan-like movement with the railway as its centre. By 23 September, about 25,000 British troops had pushed Botha's 5,000 Boers into a trap on a border lined with flags and Portuguese soldiers. Half the Boer force sought refuge in Portuguese territory; the other half eluded the British to fight another day. President Kruger had also retreated into Portuguese East Africa, and on 19 October he sailed for Europe in the Netherlands cruiser, Celderland. The war seemed over. Lord Roberts thought as much and informed the Home government that some troops could be withdrawn. ${ }^{169}$ He, himself, sailed home to England and an earldom and the Order of the Garter, after handing over command to Lord Kitchener on 29 November 1900.

The war was far from over, and the unfortunate nature it was already assuming owed much to the policy of Roberts, although history was to accord him very little odium. The field-marshal had at first treated the enemy with great rectitude, forbidding entry to houses and damage to property,

169 The Times History, Vo1. IV, p. 484. 
and seeing that all stores were paid for at market prices. However, when De wet and other commanders began to attack his supply lines, he retaliated with little discrimination. On 16 June 1900, he had proclaimed that farms adjacent to telegraph cuts or train de-railments would be burned. On 18 November, he modified this to decree the destruction of houses which were used as firing or supply bases. ${ }^{170}$ Roberts found the latter proclamation necessary because, with the towns and railways lost as sources of supply, the farmsteads became the life line of the Boer cause. Their destruction became an avowed military aim and, because the displaced families could not be left to starvation or the Kaffirs, the concentration camp became "the inevitable corollary of the policy of devastation". ${ }^{171}$ So after Komati Poort - even after Pretoria to some extent - the work of the army lacked excitement and was without glory. Of the 210,000 men Kitchener had at his disposal when he assumed command, almost 100,000 were guarding the railways. The sick and the straggling and the non-combatants accounted for tens of thousands of others. The remainder were organised into fourteen columns which were engaged in brealing up small bodies of the enemy, searching for arms, burning farms and bringing in refugees, and collecting or destroying resources such as grain and stock. 172

The history of the first and second Australian contingents during the period after Pretoria is not a happy one. It is a tale of lack of action, of diminishing numbers, of disillusionment and a desire to go home.

The advance to Komati Poort is well documented by Australian diaries and letters, but none of their authors is able to make out a case for Australian military prowess, although such was their usual desire. In the first place, the

\footnotetext{
170 James, Lord Roberts, pp. 356-7.

171 The Times History, Vo1. V, pp. 76-7.

172 ibid, p. 67; Conan Doyle, The Great Boer War, pp. 387-8.
} 
170 .

mounted infantry played a minor role, and the cavalry did little more. Much to Hutton's chagrin, his force (which now included no Australians apart from the N.S.W.A.M.C.) was frequently used on the lines of communication. "The Mounted Troops seem to have done little", he said, and attributed this to the fact that the cavalry would not close with the Boers and the mounted infantry were not given the chance. ${ }^{173}$

Amid such restricted military opportunity, the Australians were further hampered by depleted numbers. The two cavalry squadrons had been so reduced that Paterson left French in late June to view the war from the point of view of Ian Hamilton's mounted infantry. 174

The N.S.W.M.R., with an original strength of 650 made an attempt to re-form at Pretoria after chasing De Wet during July and August, but found themselves sadly deficient in horses as well as men, all their Australian mounts having been expended. Reasonable horses were found for 130 men but another 130 had to wait because their commanding officer would not accept Argentine remounts. The drive to Komati Poort went on ahead of the N.S.W.M.R. In October they were chasing De Wet again, with everybody so fed up that an officer feared mutiny. ${ }^{175}$ The Q.M.I. almost ceased to exist about this time. Colonel Ricardo had few men and no horses, and no hope that he would obtain horses. He wrote: "We all feel that the war is over and cannot get up any exictement but we do wish they would send us home". ${ }^{176}$ Ricardo had proved himself a poor leader and much of the blame for the disintegration of the Q.M.I. must rest on him. He accepted an administrative position in occupied Pretoria and ceased to show any real interest in his regiment. "Ricardo is

173 Letter XXXVII, 31 August 1900. The blood-lust seemed to be upon Hutton . "We must kill and slay if our superiffority as a race is to be established over that of the Dutch in South Africa", - Letter XXXIII, 21 July 1900.

174 Sydney Moming Herald, 1 August 1900, p. 7.

175 Letters of Major A.A. McLean, pp. 51-61.

176 Ricardo Papers, Letter to Ralph Ricardo, 29 August 1900. 
a rank failure and coward," stated one of his men, "and has been the curse of the Q.M.I."177 By contrast, Colonel Tom Price of the V.M.R. stuck to his depleted command and led it ragged and hungry into Komati Poort.

Australian disillusionment at the end of any real fighting was compounded by the nature of the new war against the civil population. Paterson publicly expressed his repugnance at the conduct of the war. At Bloemfontein he had "lightheartedly" advocated the burning of farms, but when he saw it done, with crying women struggling to remove their possessions from doomed houses in the fifteen minutes allowed them, he was disgusted. All Australians, he stated, were sick of the war and wanted to go home. There was no honour or glory in chasing a few Boers from hill to hill and burning homes over women's heads. 178

Even Captain Hubert Murray, whose personal correspondence indicates a deep and abiding concern for himself above all, could manage some feeling for the enemy. In July he was engaged in "breaking up wagons and collecting horses", an occupation he described as "not very pleasant" because he was "continually surrounded by weeping women". 179 In September he took up an appointment as Provost-Marshal with a British brigade, accepting that his principal work would be "burning farms and turning out women and children to starve". ${ }^{180}$ A little later he noted that he hated the whole business but would "have to see it through". ${ }^{181}$ And in October he was in Cape Town trying to get leave to go to England because there was nothing to do at the frontbut "steal cows". 182

177 Letters of Charles B. Holme, Letter of 8 November 1900.

178 Sydney Morning Herald, 9 August 1900, A report dated 30 June 1900. Paterson got himself home quickly enough, arriving in early September.

179 Murray Papers, Series 2, A.N.L. Letters to Wife, Letter of $22 \mathrm{July}$ 1900 .

180 ibia, Letter of 1 September 1900.

181 ibid, Letter of 19 September 1900.

182 ibia, Letter of 6 October 1900. 
The desire to rid themselves of South Africa was widespread among both officers and men. Most just wanted to go home. Others wanted to go home by way of England. Some wanted to go to the Boxer Rebellion. Lord Roberts made the majority preference possible when in October he issued an order allowing "such officers and men of 1st Contingents from overseas colonies, who have urgent reasons for desiring to return to their homes, to do so at once". 183

According to The Times History, the decision was taken in order to avoid grievance and "to do nothing to discourage the patriotic ardour which had called these men to the ranks". ${ }^{184}$ But one result was to promote considerable grievance among men of the second Australian contingent who felt they should be allowed to go home with their comrades. Roberts and Kitchener could not accede to their requests, however, because a further reduction in the mounted force was considered risky. They had to wait until the anniversary of their arrival in South Africa, although there was no obligation on the part of military authorities to release them after twelve months service. The usual term of enlistment for colonials was twelve months and such time after as they may be required.

Perhaps it was the advice of Lord Milner, added to colonial complaint, that secured the early departure of the Australians and other irregulars while the great bulk of the British army laboured on. In a letter to Joseph Chamberlain, Milner expressed grave concern at the war-weariness and discontent of the South African and overseas colonials. They need to be humoured, he suggested, so release them at an early date "with cordial thanks" and just hope that some will return to the field. ${ }^{185}$

\footnotetext{
183 Report of Major G.L. Lee, 27 October 1900.

184 Vol. V, p. 71.

185 Cecil Headlam (ed.), The Milner Papers, (2 Vols. London, 1931-3), Vo1 II, Letter of 28 October 1900, pp. 166-7.
} 
Before closing the story of the work and worth of the first and second contingent in South Africa, something should be said of an Australian unit which never experienced the exhiliration of marching with Roberts, but which languished on the western periphery of the theatre of war. This was "A" Battery of the Royal Australian Artillery, the only body of professional soldiers to represent Australia in the South African War. The New South Wales Military commandant had expected more of "A" Battery than of any other unit from the mother colony, but the men of the permanent artillery were never given a chance.

The activities of the battery over a period of eighteen months were recorded in reports by its commanding officer, Colonel S.C. Smith, to the New South Wales commandant, 186 but the tale told is one of frustration. The unit arrived at Belmont ten days after Roberts had begun his advance from that area, although it is not clear that Imperial authorities intended the battery to join the invasion force. Very soon the unit was split into three sections of two guns each and scattered throughout the rebel country of north-western Cape Colony. From then on Smith battled in vain to retain for his command some identity as a unit and to get them into action. In despair, he offered the battery for service in the Boxer Rebellion and for the grand review which, according to rumour, the Queen was to hold after the war. The old Imperial officer's reports ended on a highly expectant note as he waited at Prieska with a fraction of his force for the ubiquitous De Wet. But Frieska was too remote even for that itinerant gentleman.

Without benefit of a war correspondent, the battery completely passed from the public view, and on two occasions the New South Wales premier was questioned in parliament as to its whereabouts. But Lyne could only

186 Reports from officers. File 565/5/2, A.W.M. 
answer that it was in South Africa. ${ }^{187}$

$$
* * * * * * * * *
$$

The limited success of the Australian first and second contingents in the field (the result of limited opportunity) and the general disillusionment of their members following the fall of Pretoria, did not inhibit public enthusiasm in Australia for the war. Australians acted more like imperialists than nationalists in 1900 , and so the essential thing to them was the supremacy of British arms. Therefore, they could react with almost unbelievable fervour to the relief of Ladysmith, although no Australian unit had been within hundreds of miles of Natal. ${ }^{188}$ And they could turn the relief of Mafeking into a riotous public holiday, although the only Australians connected with the event were 100 Queensland Bushmen who arrived on the scene just as the siege was lifted. ${ }^{189}$ They were also ready to revere Roberts and Baden Powell above Tom Price and Charlie Cox. It was natural for colonial and municipal leaders to shower thanks and compliments on the great commander of the South African Field Force, but the adulation of Baden Powell was not comprehensible beyond his being in ineffectual command in Mafeking. 190

187 N.S.W.P.D., Vol. CIII, p. 578 and Vo1 CIV, p. 2020. Further parliamentary concern was shown by two M.P.'s, R. Sleath and B. O'Conor, who, during a fact-finding trip to South Africa in mid-1900, extracted a promise from Roberts at Bloemfontein that he would send the R.A.A. to the front.

188 See Sydney Moming Herazd, 5 March 1900, p. 8.

189 There were wild scenes when the news of the relief on 17 May broke, and even wilder ones on 23 May, a public holdiay throughout Australia known as Mafeking Relief Day. Pride of Empire and pride of race were the dominant themes in the celebrations, but larrikanism was a souring factor in Sydney and Melbourne. - See the Age, 21 May 1900, pp. 3, 5, 6 ; and 24 May 1900, p. 7.

190 Among the presents to B.P. were a cabbage-tree hat, a gold sword and two chargers and while colonial parliaments were still discussing the raising of memorials to Australians, a twelve-foot monument to B.P. was unveiled at Murray Bridge. - Sydney Moming Herald, 2 October 1900, p. 5;

21 December 1900, p. 7; 18 January 1901, p. 7. 
When the occasion presented itself, however, Australians were ready and willing to show their pride in their own fighting men, who had advanced as equals with British regulars in Roberts' great victories, and whose worth had been recognised by the field-marshal himself. As the relatively small casualty lists came through from South Africa, memorial services were held in suburbs and towns and hamlets and flags were sometimes flown at half-mast. But it was when the invalids came sickly back, and the depleted contingents marched home again, that the nation rose to express itself. And generally what it expressed was relief that its representatives had not failed the test of fire, and a conviction that the soldiers had brought the country nationhood and world acclaim.

From May 1900 onwards, groups of invalids returned to Australia at approximately monthly intervals. ${ }^{191}$ The rank of the statemen and military officers receiving the invalids, and the size and enthusiasm of the welcoming crowds, had declined to humble proportions by August 1900, but the reception of the first group in May was worthy of the men who had sacrificed their health for the Empire.

In Melbourne on that occasion the lieutenant-governor, the premier, and enthusiastic crowds welcomed 49 invalids from the eastern colonies. ${ }^{192}$ The men from Queensland, New South Wales, and New Zealand then went on to an even greater reception in Sydney. Earl Beauchamp, Lyne, and French all spoke comforting words and the men were taken through the crowded streets in triumph. Beauchamp told them to speak up freely about their wants and French assured them that their injuries were all treasured by the people of New South

191 The invalid rate was very high. Of the 130 officers and men of the 1st N.S.W.M.R., for instance, 50 were invalided. A minority of these were sent to England for treatment and convalescence. - J.M. Antill "Record of N.S.W. Mounted Rifles", a paper in the Macarthur Collection, M.L. 
Wales. Lyne said that there had been nothing so glorious in the history of Australia as their volunteering to help the British cause, and their display of courage that was equal to that of any other troops in the campaign. ${ }^{193}$ An editorial comment noted that Australians could no longer be regarded as mere volunteers and amateurs for now they had "a tried and attested value". 194

Individual invalids were also given enthusiastic receptions in their local areas, notable instances being a mile-long procession and mayoral reception for a Windsor trooper, ${ }^{195}$ and a welcome home at Rylstone for Lieut. Dowling of Slingersfontein fame who was greeted by a reception committee which included the military commandant. ${ }^{196}$

The men of the first contingent came home in December 1900 and January 1901 to a people flushed by the achievement of nationhood,by apparent British victory in South Africa, and by recent praise by Roberts of the colonial troops. The commander-in-chief had sent eulogistic cables to each of the colonies in November. All were similar in content and tone, for Roberts always was loath to make distinctions that would offend any section of the first imperial army, which he so proudly led. ${ }^{197}$ of the men from New South Wales, he said:

They have rendered invaluable service to the mother country, and can pride themselves on having won golden opinions from all ranks. I cannot praise them too highly or thank them sufficiently for the gallant work they have done in South Africa. ${ }^{198}$

\footnotetext{
193 Sydney Morning Herald, 30 May 1900, p. 5.

194 ibid, p. 6.

195 ibid, 2 July 1900, p. 8.

196 ibid, 9 June 1900, p. 9.

197 For this reason, Roberts' evidence before the Elgin Commission was not very meaningful.
}

198 Sydney Morning Herald, 6 November 1900, p. 5. 
The returned soldiers were accorded a series of welcomes as the Harlech Castle, carrying men from all colonies, made its way around the Southeastern coastline. Adelaide provided the first adulation. Amid huge Saturday crowds, Colonel Tom Price led the sunburned and gaunt veterans in procession. Lord Tennyson was too ill to review the troops but the premier and other ministers proclaimed their worth. The chief secretary called upon the testimony of Lord Roberts as proof of the men's courage. 199

The Melbourne reception was under-written by a half-day public holiday and a full-day school holiday, although what took place was hardly children's fare. The Age described the welcome as a "lamentable fiasco" and something akin to the "saturnalia" of Mafeking Day. It suggested that 5,000 members of the defence forces who marched in the procession should have been used to control the crowds. 200

The units marched off the pier to the tune of When Johnny Comes Marching Home and went on up through the humble dwellings of South Melbourne where pictures of "Bobs" and B.P., cut from illustrated periodicals, adorned doors and windows. But the lines of veterans soon lost all their military aspect as young women and others mingled with the heroes.

A luncheon presided over by the premier, Sir George Turner, gave many notables an opportunity to praise the men and assess the significance of their service in South Africa. The lieutenant-governor, Sir John Madden, stated that Australians stood a far different people from what they were a year before, and all because of the work of the soldiers in the field.

It is you who have broken the sod of our glory, and you will be remembered as Scotland regards Bannockburn, as Ireland regards Limerick, as Holland remembers the men who fought with (sic) Alva.

199 Age, 3 December 1900, p. 5.

2006 December 1900 , p. 4. 
Turner remarked that the contingent had gone away as untried men but had returned with the praises of "the best soldier in the British Empire", and McCulloch claimed that Australia had proved that she "could produce children equal to any other in the world on the cricket, the battle or any other field". At this point Major Cameron of the Tasmanians (an ex-Imperial officer) thought it necessary to remind everyone that the Australians weren't the only people in South Africa and that it had been the British army which had borne "the heat and battle of the day and did the lion's work".

That night, amid fireworks and illuminations and revelry of "young men of riotous instincts", the veterans were "shouted" by the populace, who paid no heed to Roberts' request to the Empire not to ply returning men with alcoholic beverages. 201

Huge crowds also filled the streets of Sydney to welcome the troops from New South Wales, Queensland and New Zealand, although it was a working day and no holiday had been proclaimed. Both Lyne and See, the chief secretary, assured the veterans that they had done much more than Australia had dared to expect; and they dwelt at length on those "sleeping in South Africa". 202 When more troops returned on the Orient, early in January 1901, Lyne was obliged to say much the same things again, but Edmund Barton, the first prime minister of Australia, was moved to a more generous utterance: "The deeds they have done", he said, "were worthy of the company in which they were done and of the brave enemy they fought". ${ }^{203}$ Meanwhile the man who started it all was lying on his death-bed. J.R. Dickson, Commonwealth minister for defence and recłipient in the New Year honours of the K.C.M.G. which his Labour opponents claimed he was seeking when he offered Queensland troops in

\footnotetext{
201 Age, 5 December 1900, pp. 6, 8 .

202 Sydney Moming Herald, 7 December 1900, p. 5.

203 ibid, 9 January 1901, p. 5.
} 
July 1899, was dying within earshot of the revelry.

Only two colonial parliaments took steps to honour the return of the first contingent. South Australia, acknowledging the lead given by the New Zealand legislature, passed a motion tendering thanks to the troops and extending sympathy to the relatives of the fallen. The matter was completed with minimal discussion. ${ }^{204}$ A motion in the Western Australian legislature was far more laudatory and was supported by considerable debate. It paid tribute to the valour and contribution of the Western Australian fighting men on the authority of "the Commander-in-Chief and his Generals". 205

As the months rolled by other contingents returned, but never to the same public enthusiasm. In fact, the "welcome homes" followed the same pattern as the "send-offs" and the receptions to the invalids: diminishing crowds, diminishing stature of the official welcoming parties, and diminishing plaudits. All of which was perfectly understandable, for the basis of the lionization of the Australian soldier was very insubstantial. Political leaders could not continue to make flamboyant speeches whose raison-d'être was the polite and proper praise of Lord Roberts. And the spectacleloving Australian crowds soon tired of a recurring spectacle. Continuing enthusiasm for the departure and arrival of troops was possible only if those troops were fighting bloody battles in a noble cause, but the desperate fighting had ceased almost before the Australians had reached the field, and feeling against the Boers had subsided once they ceased to pose a threat to Imperial prestige, and once the press was obliged to drop the fiction of an evil, grasping foe in the face of contrary testimony from such correspondents as the widely read and highly respected Paterson. The work of the first and second contingents was not without merit, however, and was very significant

\footnotetext{
204 S.A.P.D., 1900, pp. 1014-15.

205 W.A.P.D., Vol. XVIII, 1900, pp. 2080-8.
} 
in the development of Australian nationalism. Drawn predominantly from the part-time military forces of the colonies, they were able to make an immediate contribution to the war. Because their training had been along Imperial lines and their discipline fairly well developed, they had merged easily with British units. Contingent members had shown a keenness to fight and a dash in battle that had distinguished them from the more stolid Tommy. Their reputation for dash was partly a product of their excellent horsemanship, but fearlessness was also a factor. Australians did not throw up a fight readily and there is no parallel among them of the large-scale surrenders that plagued their British counterparts, the irregular Imperial Yeomanry. 206 Sunnyside, Pink Hill, Vet River, and Diamond Hill were minor engagements, but in them Australians had shown a competence and a reckless courage that heralded bigger things. Roberts, Kitchener, Hutton and other British generals could therefore praise them with confidence and the Australian people could justifiably believe that their representatives had brought added recognition to the new nation by their military prowess.

206 The corpswas referred to in South Africa as "I Yield" and "De Wet's Remounts". 


\section{CHAPTER IV}

\section{The Bushmen, the Draft Contingents, and the Australian Commonwealth Horse}

The first and second contingents had not been easily raised from among the part-time military forces of the Australian colonies, but the six contingents that followed were drawn from applicants so numerous as to be an embarrassment to recruiting officials.

The main reason for the changed situation was that the later contingents were open to a much larger section of the population. Influenced by the success of irregular mounted forces in the early months of the war, British authorities began to encourage the recruitment of good horsemen who need not possess any military training. This suited the Australian colonies admirably. They had an abundance of skilled horsemen, and there seems to have developed from the very outset of war a wide belief that the bushman, with his ability to ride, to endure, to improvise and to find his way, was the natural opponent for the unorthodox Boer. Therefore governments, and under their influence, military authorities, made the bushman the core of the third and subsequent contingents.

The raising of these later, non-militia contingents ${ }^{1}$ had a further common characteristic: the decisions to create them were made after external influences had been brought to bear upon the responsible executives.

The enthusiasm of the public was not an apparent influence, however, for the exuberance it had displayed at the novelty and spectacle of the first two contingents was not maintained. The dispatch of the two Bushmen contingents delayed the decline in the manifestation of public support for the war,

1 The fifth to eighth included some militia members, but the distinction is convenient and valid enough. 
because they were also a novelty: purely citizen soldiers who bore no taint of militarism. They also carried about them the romanticism bestowed by the literature of the 'nineties. The populace became quite inarticulate in the last twelve months of the conflict. We have no idea of their attitude to the increasing ferocity of the war against the civil population of the Boer republics. They could have expressed any antagonism within the framework of an incipient peace movement which developed late in the war, but did not do so. Their corporate silence could be taken to mean acquiescence in the dispatch of further contingents, or it could denote the submission of the ordinary man to the power of the press, which continued to promote the Imperial cause and scorn those who raised a voice in protest.

But public hubbub was apparently not needed to keep the contingents sailing off to South Africa. Sometimes the motivating factor was a direct call from Kitchener or an implied call from The Times; sometimes it was an initiative taken by Canada or New Zealand; and sometimes it was agitation by a subordinate politician backed up by the press. Supporting factors were the understandable continuing support for the war by military establishments, and the perplexing willingness of young Australians to flock to the ranks to participate in a war that had long ceased to promise an atom of glory.

The history of the non-militia contingents is notable, then, for the circumstances of their raising. It is less notable for what they achieved in South Africa. However, several incidents in the field brought Australian fighting men under critical scrutiny, and provided a test for the sincerity of Australian opinion, which had early promoted the contingenter to equality with the best soldiers in the world. 
Definite action to form a Bushmen's contingent emerged from a series of happenings which were reported in the press in the week beginning 21 December 1899. On that day was published the text of a cable from the Colonial Office which stated that volunteers for the second contingent "must be good shots and competent riders, but need not be members of any regular trained force". ${ }^{2}$ The following morning, the London cables reported that Canada had offered the services of 1,000 experienced "rough riders", ${ }^{3}$ and that afternoon a member suggested to the New South Wales Legislative Assembly that the government send to South Africa a body of "bushmen who were rough riders and good shots". ${ }^{4}$ Three days later it was reported that the lictorian government had suggested to Lyne the formation of a Bushmen's corps, ${ }^{5}$ and after a further two days, the Age noted that Lyne had informed the Victorian premier that a corps of mounted bushmen was being raised privately in New South Wales. ${ }^{6}$

New South Wales quickly took the lead. A committee of citizens was formed, with J.R. Carey as president and J.M. Atkinson as secretary. Its members included a number of the great pastoralists of the colony. The plan was to raise a force of 500 bushmen for service as scouts in South Africa, to mount them on donated horses, and to raise enough funds to pay and equip them, in the manner of the first two contingents, for six months in the field (the anticipated duration of the war). It was considered that the recent British military calamities were the result of poor scouting. Therefore, the

2 Age, p. 6. This left the way open for the bushman with no military training and a number of them sailed with the second contingent.

3 ibid, 22 December 1900, p. 5.

4 ibid, 23 December 1899, p. 8.

$5 i b i d, 26$ September 1899, p. 6.

628 September 1899, p. 6. The Victorian minister for defence claimed later that he had waited a week for Lyne's reply. - Age, 10 January 1900, p. 8. Having regard to the antipathy that existed between the two governments, it is easy to suspect Lyne of taking steps in that week to foil the Victorian initiative, which could have been prompted by the Colonial office cable or the Canadian offer. 
original intention was that the Bushmen be attacked to British regiments in lots of 20 to 50 to be the eyes and ears of the regular forces. ${ }^{7}$

The committee set out to raise $£ 30,000$ and 500 horses. It raised the money, thanks to donations of £5,000 each from S. McCaughey and W.R. Hall and E3,000 from S. Hordern, but it ended up buying almost half the horses needed. ${ }^{\theta}$ The government did not subsidise the contingent in New South Wales. Lyne assured the committee that he would not see the movement short of a few thousand pounds, but he hoped that it could maintain its voluntary nature so that the force could go forward as a truly Citizens' Bushmen's contingent. ${ }^{9}$ French was instructed to work in concert with Carey and provide officers and N.C.0.'s to test and train the recruits.

Another unsuccessful effort was made to create a federal force after the Colonial Office accepted Lyne's offer of a Bushmen's contingent and undertook to send troopships. The New South Wales premier telegraphed his counterparts in the other colonies, and Carey communicated with the mayors of the colonial capitals, each wanting to know the number of men they could contribute to the contingent. ${ }^{10}$ By this time, however, most colonies were going it alone in the accustomed fashion, making their individual offers to Chamberlain and regarding their contingents as independent units. But most of them encountered financial difficulties.

The movement lagged so badly in Victoria that the lieutenantgovernor addressed a press letter to the people of Victoria, promoting the Bushman concept and asking for financial support. ${ }^{11}$ This was not forthcoming

7 Report of the Royal Commission of Inquiry into Claims of Members of New South Wales Contingents in South Africa... (Sydney, 1906), p. 173, Hereafter called the Royal Commission on Pay.

8 Sydney Morming Herald, 28 February 1900, p. 7.

$9 \quad i b i d, 27$ January 1900, p.10.

10 ibid, 22 January 1900, p. 8.

11 ibid, 19 January 1900, p. 8. 
in the amounts required, and cabinet was obliged to take up the responsibility of sending a contingent of 250, after expressing regret at the poor response of the public. ${ }^{12}$ The Western Australian government found it necessary to subsidise the movement pound for pound, ${ }^{13}$ and the Queensland government assumed full responsibility for the contingent; partly out of enthusiasm it seemed, but mainly because the organizing committee had only raised $£ 632$ by 1 February. ${ }^{14}$ The committee in South Australia reached its target without government assistance by making an appeal through the mayor of Adelaide for contributions to be sent to the Bushmen's Fund in preference to the Patriotic Fund, and by the successive sale without delivery of the horse, Bugler. This steed was paraded through town and country, and was responsible for raising $£ 2,500$ of the $£ 12,000$ needed to send 100 Bushmen to war. ${ }^{15}$

The response of the Australian people to the various Bushmen's funds was average to poor. Contributions were certainly not proportional to the wild enthusiasm of the street crowds during the same period, and it is reasonable to regard the situation as evidence of the lack of depth in support for the war. Very modest support for the Patriotic funds corroborates this view. ${ }^{16}$

By the end of February, all colonies had raised their contingents. The most interesting recruiting campaigns were in New South Wales, Victoria, and South Australia. The New South Wales Bushmen's committee had no trouble

12 ibid, 30 January 1900 , p. 6 .

13 ibid, 25 January 1900, p. 8.

14 ibid, 1 February 1900, p. 8.

15 E.G. Blackmore, The Stom of the South Australian Bushmen's Corps, 1900 (Adelaide, 1900), p. 19.

16 By 30 March 1900 , contributions to the funds had fallen to a trickle, and the total Australian subscription amounted to sixpence per head of population. - Argus, 30 March 1900, p. 6. 
in getting recruits. Its biggest problem was the sheer physical difficulty of selecting 500 men from almost 2,000 accredited bushmen volunteers, and having less than a month in which to do so. To make the task more difficult, there was friction between the committee and the military officers assigned to help in the preparation of the volunteers. The officers resented the intrusion of civilians into military matters, and the committee were keen to assert their wishes in organizing the contingent. The committee also had to cope with fraud on the part of incompetent volunteers who got friends to take riding and shooting tests for them, although the incidence was probably not high because fraudulent recruits were informed upon by disgruntled rejects. ${ }^{17}$ There was also the problem of members of parliament who demanded that their recommendation of a bushman be accepted as an alternative to the recommendation of a pastoralist. ${ }^{18}$

The recruiting procedure was for a volunteer to complete an application form, which had to be signed by a member of the committee or a military or police officer in charge of a district as an endorsement of the applicant's ability to ride and shoot. A local medical officer's signature was also required as evidence of physical fitness. But even then the application was incomplete without a letter from a pastoralist commending the volunteer as an experienced bushman. ${ }^{19}$

This procedure alone would have meant a decent standard of recruit, but demanding medical, riding, and shooting tests at the encampments at Randwick rifle range and Kensington racecourse ensured that the contingent was composed of fit men, at ease on a horse and handy with a rifle. What they

17 Royal Commission on Pay, Evidence of J.M. Atkinson, pp. 47, 278.

18 "Select Committee on the Administration of the Military Department", Evidence of J.R. Carey, p. 226.

19 Sydney Morning Herald, 29 January 1900, p. 8. 
were beyond that, the committee did not care, for as Atkinson said, "We did not inquire into the morals or the morality of the men at all". 20 But one newspaper was prepared to say that "fully 60 percent" of the contingent were a fine stamp of intelligent manhood. ${ }^{21}$

An extant nominal roll of "A" squadron of the New South Wales Citizens' Bushmen helps build up a picture of the contingent. They were bigger men than the usual Australian, having an average height of 5 feet 9 inches. With an average age of 26 years and 10 months, they were old enough to have had extensive bush experience, but young enough to possess the dash and recklessness of youth. If it was the rural aristocracy who supplied the bulk of the equipment and other means of war, it was the rural proletariat who climbed lithelyinto the gift saddles. Only 18 members of the squadron of 120 were men of property. ${ }^{22}$ In order to control effectively "the wild men", as French called them, ${ }^{23}$ officers were appointed principally from the defence forces. Of the 19 commissioned men, only 5 had not previously served as officers. ${ }^{24}$

The organisation of the Victorian Bushmen's contingent was in the hands of a committee comprised of D. McLeod, M.L.A., Rear-Admiral W.B. Bridges, pastoralist, and a Mr. Pearson. McLeod admitted during discussion of the Victorian Military Contingent Bill (No. 3) that there had been grave shortcomings in selection procedures, for although 1,700 men had volunteered only 400 were invited to attend for tests. And they had been invited solely on the basis of their letters seeking enrolment. If fact, 150 of these had originally

20 "Select Committee on the Administration of the Military Department", p. 216. 21 Sydney Morning Herald, 28 February 1900, p. 7.

22 Uncatologued MSS, Set 267, M.L.

23 Royal Commission on Pay, p. 140.

24 Supplement to New South Wales Government Gazette, 12 April 1900. The officers were selected by French from lists submitted by the committee. 
been rejected by ballot, leaving 250 volunteers from which to select 200 . But failure to report, along with rejections, made it necessary to call up the entire 400. McLeod acknowledged that under such a system many of the best men would not have been given a fair chance. In answer to members who questioned the genuineness of some bush applicants, he admitted that there were a number of city-dwellers in the contingent, but claimed that they had worked in the country. ${ }^{25}$ As in New South Wales, officers were drawn from men with previous military leadership experience, and the ranks were filled predominantly from the lower order of rural society. ${ }^{26}$

Of all the colonies, South Australia came closest to making the. raising of the Bushmen's contingent entirely a citizens' affair, and the title of Citizens' Bushmen, used only of the New South Wales contingent, could more validly have been applied to the South Australians. Committees did all the planning, referring occasionally to the military commandant for advice, and set about the task of recruiting 100 men on the basis of "bush experience, general physique, intelligence and character". Twelve hundred written applications were received in answer to press advertisements. Those volunteers under 25 were rejected first, as not of sufficient bush experience or maturity. This Ieft about 1,000, who were reduced to the required number by a series of eliminations, including tests of fitness and horsemanship.

The position of commanding officer was eagerly sought by subalterns of the defence force, but the selection committee, advised by the commandant, considered that no officer of the rank of captain had the qualifications to lead such a unique body of men. It looked for "some first-class civilian, used to authority", and the choice fell on S.G. Hubbe, chief inspector of vermin destruction, and the man who had led the South Australian stock route 25 V.P.D., 1899-1900, Vo1. 93, pp. 320-1. 26 Argus, 12 February 1900, p. 6; 14 February 1900, p. 14. 
expedition from Oodnadatta to Fowler's Bay. ${ }^{27}$

The various colonial corps embarked mainly in the first days of March, and if the size of the farewelling crowds was a barometer of public interest in the war, there was a discernible waning. This was despite the fact that the granting of public holidays or half-holidays for the occasion was the rule. Only from South Australia were there reports of crowds in excess of those that farewelled the first two contingents. It was estimated that over 100,000 people thronged the streets of Adelaide. ${ }^{28}$ Melbourne's farewell was without benefit of bands and military escort, but for the first time the departing troopswere mounted, and this provided new interest for the crowds. Most of the Bushmen carried flowers handed up to them by girls, while at the wharf many people wept and the lieutenant-governor said with pride, "We have chosen you from among ourselves". ${ }^{29}$

The Sydney crowds were reckoned to be smaller than for the departure of the second contingent, but nonetheless were estimated at 200,000 . In contrast with the Melbourne ceremony, the Sydney farewell neglected none of the pomp and circumstance that had characterised the departure of the second contingent. There was a military escort of 1,600 troops and the usual procession of official carriages. These were headed by the ministerial vehicles, one of which contained a Queensland guest, A. Dawson of the Labour opposition. Dawson had opposed the first contingent, supported the bill to send the second, and now was absorbing some of the reflected glory of the departure of the third. A carriage of ministers of religion followed their temporal brothers,

27 Blackmore, The Story of the South Australian Bushmen's Corps, pp. 8-11. Although Hubbe was Australian born, his German parentage brought anonymous complaints to the selection committee. - Advertiser, 3 March 1900, p. 8 .

28 Advertiser, 7 March 1900. p. 4.

29 Argus, 12 March 1900, p. 4. 
and later in the procession came a waggonette of Ronan Catholic clergy. But the centre of interest for the people were the 500 superbly mounted Bushmen. They sat their steeds with the ease and vanity of true bush horsemen, their "flashness" enhanced by the uniform of the N.S.W.M.R. and a distinguishing "A.B.C." on the shoulder. There were speeches at the wharf. The lieutenantgovernor, Sir Frederick Darley, warned them against impetuosity (possibly a result of Slingersfontein and Pink Hill), and Lyne spoke of courage and loyalty. Poor French could only express his disappointment at again failing to get to South Africa. ${ }^{30}$

In the view of the press, there was no doubt that a new and distinctive Australian product had emerged - the bushman soldier. A leading article in the Sydney Morning Herald proudly announced the event and hailed the Bushmen as the possessors of "all the mobility of the Boers, all their endurance, their knowledge of rough life, and their courage". ${ }^{1}$ The Advertiser saw the corps as composed of "the only romantic figure left in colonial life". The Bushmen would fill a disastrous scouting weakness in the British army, and develop into fine irregular troops, being "tough and wiry, with abundant resource and self-confidence, steadfast and trustworthy". ${ }^{32}$ The Argus also idealised them. ${ }^{33}$

The final accolade came from the pen of Premier McLean, a versifier of some note among his friends, who now submitted his art to the public gaze in honour of the warriors mustered from the bush.

\footnotetext{
30 Sydney Morming Herald, 1 March 1900, p. 7.

3128 February 1900, p. 6.

3218 January 1900 , p. 4.

з 33 February 1900, p. 12.
} 
... O'er Austral lands the bugles blow, And rolls the martial drum;

Their warlike strains like magic flow, They reach the Bushman's home:

From hills where snow-fed rivers flow, From forests deep, from mountains brow, From out each darksome vale below,

The hardy Bushmen come ... ${ }^{34}$

$$
* * * * * * *
$$

While the Bushmen were being selected and given their limited training, discussions concerning their eventual deployment in South Africa were proceeding in high places. The board of the British South African Company had become very concerned over the unprotected state of Rhodesia, fearing a Kaffir rising as well as a Boer invasion. Approaches were made to the Imperial government for troops but it was reluctant to dissipate its forces further. It did agree, however, to finance a force of 5,000 men if the company took responsibility for raising them. The Home government stipulated that the force be raised outside Britain. As only a limited number of recruits were available in Rhodesia, the company sent a confidential agent to initiate a recruiting campaign in Canada and the United States. At this point the Imperial government stepped in. Afraid of the repercussions of an unofficial scheme of obtaining volunteers in North America, it decided to send Imperial forces drawn from British Yeomanry and Australian volunteers. There were already the 1,300 Australian Bushmen about to embark, so why not direct them to Rhodesia and request a further 2,000 from the same source ${ }^{35}$

Chamberlain's cable to Lyne sought 2,000 men "of a similar kind to the Bushmen". They would be paid $5 /-$ a day by the Imperial government, which would also meet other expenses involved in the raising of the force. Colonial governments were simply asked to act as agents for the Home authorities. Lyne

\footnotetext{
34 Argus, 20 March 1900 , p. 5.

35 The Times History, Vo1. IV, pp. 363-8.
} 
wasted no time, again seeing himself in the role of co-ordinator of a federal force. He passed on the text of the Colonial Office cable on 28 February. Within four days all other colonial premiers had agreed to co-operate, Lyne had notified Chamberlain, and Chamberlain had expressed his pleasure at Australia's "patriotic readiness". ${ }^{36}$

The only difficulty arose when the New South Wales premier suggested representation in the contingent on the basis of population. Philp demanded a larger share of the contingent for Queensland, and was particularly indignant that Victoria was allotted 626 places, while Queensland was allotted only 270. He felt that this should not be, in view of the "limited assistance previously rendered by Victorians" and the abundance of cheap horses and good bushmen in Queensland. ${ }^{37}$ Unable to get anywhere with Lyne, Philp appealed to the Imperial authorities and was allowed an additional 120 places. ${ }^{38}$

Chamberlain's request for more troops seemed to set the final mark of approval on Australia's fighting men. The Sydney Morning Heratd stated that the request was "flattering to the newly-born military spirit of Australians" and believed that "no greater compliment" could be paid to the people or the soldiers they had sent to the front. ${ }^{39}$ The fourth contingent quite properly took the name of the Imperial Bushmen's Contingent. It was raised at Imperial request and was the responsibility of the Home government in all matters of pay, allowances and pensions.

The ranks of the Imperial Bushmen were filled with even greater ease than those of the Australian Bushmen. More than 12,000 volunteers came forward for the 2,000 available places. Victoria and South Australia had double the number that offered for the previous contingent, although applicants were given only a week in which to forward their names. Victoria had over

36 Sydney Morning Herald, 6 March 1900, p. 7.

37 ibid, 30 March 1900, p.5.

38 ibid, 2 April 1900, p. 8. Philp's case was helped by the presence in London of Dickson as a federal delegate.

395 March 1900, p. 6. See also Argus, 6 March 1900, p. 4, and Advertiser, 7 March 1900, p. 4. 
4,000 volunteers from which to select 620.40 South Australia had over 2,000 from which to select $200 .{ }^{41}$

Greater efforts were also made to recruit none but real bushmen, for Chamberlain had specified that type. Recruiting officers in New South Wales and Victoria moved into the hinterland to get the genuine article. "Go away out to the end of the railway track"; French told his selection committee. ${ }^{42}$ And that is where he enlisted most of his recruits. South Australian officers apparently did not go so far out along the tracks, because a detailed nominal role published in the Advertiser gives many urban occupations. ${ }^{43}$ With ten volunteers seeking each place in the contingent, however, the men selected must have all displayed those skills commonly associated with the bushmen.

Colonel Tom Price had complained in the early months of the war of a lack of interest in the defence forces on the part of the wealthier classes in Victoria. His was a criticism that could validly have been applied to all colonies. The first three contingents were overwhelmingly proletarian. The Imperial contingent showed a decided increase in middle-class representation, however. Not only had more of this category come forward, but selection committees had clearly favoured them. The trend was probably the result of the increased status of the soldier, which had reached its peak in March with the general acceptance in Australia of the worth of the men of the first contingent and the Imperial call for more Australians. It was clearly discernible in South Australia and New South Wales. In the former colony there was little scope for a place in the commissioned ranks of the contingent,

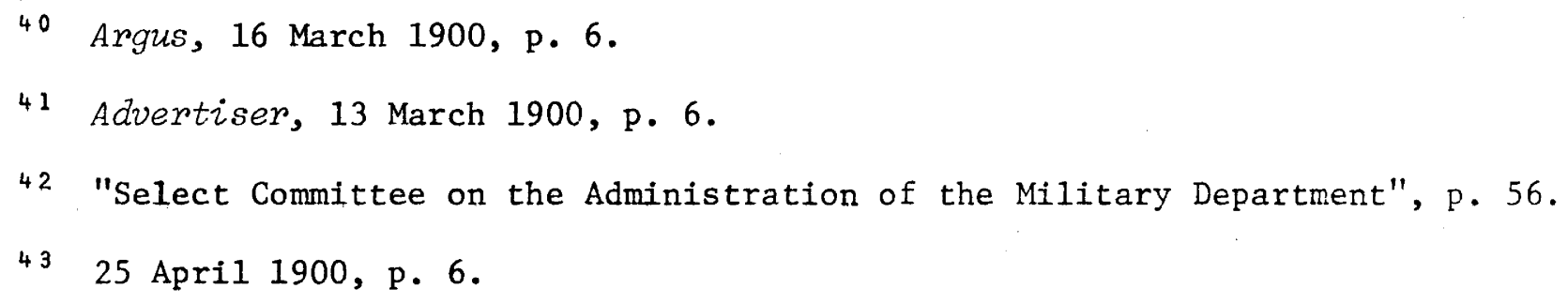


because the military commandant, who handled the recruiting, gave all but two places to officers of the defence forces. ${ }^{44}$ But many men of substance gained selection as non-commissioned officers or troopers. 01d boys of St. Peter's and Prince Alfred colleges alone accounted for 34 places in the contingent. 45

In New South Wales the emergence of a patrician element was most noticeable in the fight for 33 commissioned positions. A total of 222 persons applied, of whom 116 had previous military experience of varying significance. But of those selected 10 had no military experience of any kind, ${ }^{46}$ although they had high social standing. Three of them, John Oxley, Allan Gidley King, and Fitzwilliam Wentworth, came from old and revered families. ${ }^{4}$

The Imperial Bushmen were more fortunate than other contingents in that they had a month and more of basic training. This probably accounts for the praise they received for their military bearing during their progress to the docks, but perhaps they carried themselves so erect out of sheer pride at wearing the uniform which now stood for proven soldiers. That is certainly what they were told on all sides as they left for South Africa. The Advertiser saw Australia henceforth as a recruiting ground for the War office, ${ }^{48}$ and the Sydney Morning Herald wondered how Australians could be done without in South Africa. ${ }^{49}$

\footnotetext{
44 One of these two appointments went to E.A. Roberts, a Labour M.L.A., who had strongly opposed the sending of the first contingent.

45 Advertiser, 12 April 1900, p. 6.

46 "Select Committee on the Administration of the Military Department", p. 332 .

47 For personal details of the officers selected see Sydney Morning Heraza, 13, 14, 17, 18, 19, 21, 23 April 1900; and Supplement to the New South Wales Government Gazette, 12 April 1900.

$48 \quad 1$ May 1900 , p. 4.

4923 April 1900, p. 6.
} 
Colonial governments were generally reluctant to declare public holidays for the departure of the fourth contingent. The omission may have owed something to custom having staled; but it could be attributed with greater certainty to an official attitude which regarded the Imperial Bushmen as a force for which Australian governments had little or no responsibility. Sydney was given a holiday on 23 April, St. George's Day, but this was mainly to balance the public holiday granted on St. Patrick's Day in recognition of the valour of the Irish regiments in the Natal compaign.

Despite the help of a public holiday, the Sydney send-off was not an enthusiastic affair. Decorations were sparse and the cheers just as sparse. For the first time, Lyne did not join his fellow ministers in the procession, but made a farewell speech at the docks in which he simply advised the troops to follow in the path of those who had already made a name for Australia. ${ }^{50}$ The Adelaide farewell was the only one that was reported as equalling the earlier farewells in enthusiasm, yet it was without benefit of a public holiday. 51

With the Imperial Bushmen on the high seas, Australia's commitment to the war totalled 6,600 men. This represented less than two percent of her population, but the enlistment and dispatch of four contingents within six months had given public,press and parliaments plenty to divert themselves with. The excesses of statement and of ceremony which had surrounded the first contingents had moderated by the time of the departure of the Imperial Bushmen, however, and in the months that followed a self-satisfied quiescence fell upon the land. This feeling of well-being was sustained by the brief

\footnotetext{
50 Sydney'Morning HeraZd, 24 April 1900, p. 6.

51 Advertiser, 1 May 1900, p. 4. Imperial loyalty flourished strongest in this most British of the Australian colonies.
} 
London cables which fed the local press, and which occasionally reported an action involving Australian units, or the praise of a British commander. Little more was needed and Australians got precious little more, for the correspondents covering the war for the major dailies of south-east Australia a11 ceased writing during 1900. W.J. Lambie of the fGe, Daily Tele rrapin and Advertiser had been killed in February. W.T. Reay of the Melbourne Herald and South Australian Register had been forced home by illness when the army reached Bloemfontein. Donald Macdonald of the Argus and Sydney Morning Heral.d had returned to Australja a physical wreck after being besieged in Ladysmith. A.B. Paterson of the Argus, Sydney Moming Herait, and Adverotiser had left the battlefield in July, two months before Roberts had reached Komati Poort. And Frank Wilkinson of the Sydney Faily Telegraph, the Age and the Advertiser also left South Africa before the end of 1900. Only Chaplain James Green of the Citizens' Bushmen continued to contribute newspaper articles into 1901. The Australian contingents thus disappeared for the most part into a communications vacuum, and that was to be the case for the rest of the war. Soldiers' letters to relatives appeared in the press in considerable numbers but they were rarely objective accounts. Most frequently they were tales of braggadocio and plunder that the radical press seized upon with glee as proof of the degeneracy of the conflict.

The home front came to 1ife again in December 1900, however, with the return of the first contingent, and moves to send further troops to South Africa.

$$
* \quad * \quad * \quad * * *
$$

When Roberts handed over the South African command to Kitchener at the end of November, the Boer armies had been fragmented but not beaten. They had formed into scores of highly mobile commandos which constantly 
harassed British troop movements and lines of supply. Only mounted trocps were relevant against such a foe and there was an increasing dearth of these. Roberts had been reluctant to let the first colonial contingents return home and had refused to release the second Australian contingent before it had served twelve months in the field. Kitchener was so concerned that in late December he took action to obtain more mounted men from Britain and the colonies.

On 28 December it was revealed in the press that Chamberlain, on behalf of Kitchener, had suggested to the Australian colonies that they keep up the strength of their forces in South Africa by draft contingents. Pay would be at the rate of $5 /-$ a day and the Imperial government would also supply equipment. ${ }^{52}$

A1though the colonies were within days of federating, there was still a marked desire among them to act individually. On 29 December it was reported that Tasmania was enlisting men. ${ }^{53}$ on 3 January it was reported that South Australia was enrolling men for a fifth contingent. ${ }^{44}$ And on 4 January it was made public that Sir George Turner had approved the request of his minister for defence, the ultra-imperialist McCulloch, to raise a contingent of 400 men. ${ }^{55}$

Apparently some colony or colonies had notified British authorities of a willingness to send troops, for on 31 December Kitchener cabled the South Australian governor:

\footnotetext{
52 Sydney Morning Herazd, p. 5.

53 ibid, p. 9.

54 ibi.d, p. 7 .

55 ikid, p. 5.
} 
I understand that Australia will send drafts

to complete the contingents in the field. If

so, when may I expect them? I wish to express

my high appreciation of the most valuable services

of the Australians... ${ }^{56}$

During all this activity, the colonial premiers were in Sydney for Commonwealth celebrations. On 7 January they met briefly to give joint approval for more troops. The tone of Lyne's cable to Chamberlain was no longer that of a suppliant for Imperial favours; it was the rather imperious tone of a merchant who spoke for a product in high demand. The states would comply with the desire of the Imperial government for draft contingents, but British authorities must provide transport and equipment, and give New South Wales soldiers serving in South Africa the option of returning home. ${ }^{57}$

The reasoning behind individual state action was that the new contingents to be raised were actually drafts to replace men already sent by the separate colonies; in addition, the Commonwealth department of defence was not yet functioning.

Recruiting began, and the rush of volunteers was so great that the new states immediately took up competitive postures. In succession, Victoria offered the War Office a sixth contingent of $500 ;^{58}$ New South Wales offered to send 2,000 instead of the 1,000 which was her quota in the force of 2,300 originally planned; ${ }^{59}$ South Australia announced an offer of a sixth contingent; Queensland offered an additional 100 men, ${ }^{60}$ and then undertook to fill

56 ibid, 4 January 1901 , p. 5. Cables were sometimes sent to the South Australian governor for transmission to the other colonies because South Australia was at the end of the British cable route.

$57 i b i d, 8$ January 1901, p. 5. He was referring to the second contingent.

58 ibid, 19 January 1901, p. 9.

59 ibid, 5 February 1901, p. 6.

60 ibid, 7 February 1901, p. 7. 
another steamer if it were sent; and Western Australia and Tasmania each decided to send a sixth contingent. ${ }^{61}$

Just before this whole frenzy had begun, the prize-winning ode for Commonwealth Day, written by George Essex Evans, was announced. It is notable that the poem made neither reference nor allusion to Australia's military prowess, but it did contain two lines of supreme irony:

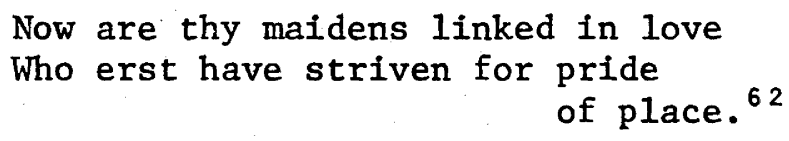

The initiative for the draft contingents had begun with Imperial authorities but it had very soon passed to the premiers. Why had they pressed for the acceptance of additional troops when the war was generally regarded as being all but over? Admittedly there were stimulating factors such as the call from Kitchener, the enthusiastic public reception of the returning first contingent, and a rush of volunteers for the fifth contingent. But the pattern of activity of the parliamentary executives during January and February implied that state particularism was the prime motivating factor. And McCulloch was the man who started the bidding on this occasion. The minister for defence had served a term in the political wilderness after the dispatch of the first contingent, but he returned to resume the military. portfolio with great enthusiasm, and much more was to be heard of him.

When recruiting began for the fifth contingent, the cry once more was for the bushman Recruiting officials in Sydney were besieged by city men who made great efforts to prove they were bushmen, but only a few of the best were taken because 1,500 applicants from the country were heading for Sydney on free rail warrants after rough local medicals. These were the

\footnotetext{
61 ibid, 14 February 1901, p. 7.

62 ibid, 27 December 1900, p. 5.
} 
men recognised by military authorities as "most fitted to do credit to New South Wales". 63 And when it was announced that the New South Wales contingent would be doubled, the first move was another call to the bush. ${ }^{64}$ Queensland also sought the country man and Philp was able to announce proudly that "fully 90 percent" of the fifth contingent were bushmen. ${ }^{65}$

In all contingents there was quite a leavening of returned men and members of the defence forces. The latter category had gained few places in the Bushmen's contingents because of the peculiar nature of those corps, but they received preferential treatment in the draft contingents. This was particularly the case in the commissioned ranks. Of 58 officers in the enlarged New South Wales fifth contingent, only five were listed as "gentlemen". The rest were from the defence forces and of these 38 had seen service in South Africa, either as officers or in the ranks. ${ }^{6}$ Victoria's 46 officers all had previous military experience. Eleven of them were returned men. ${ }^{67}$ During February, March and April 1901, close to 5,000 Australians left for South Africa. Some states sent their men separately as the fifth and sixth contingents. Others used the title of fifth contingent to cover the original force raised and the additional troops offered. Whatever the terminology used, the contingents sent represented an expeditionary force of high quality. Large numbers of volunteers had ensured high physical, riding, and shooting standards. Once again the men were overwhelmingly from the bush with all that denoted in terms of horsemanship, endurance and commonsense. And there was a nucleus of experienced officers and men to lend a stability
63 ibid, 18 January 1901, p. 7.
64 ibid, 6 February 1901, p. 7.
65 ibid, 9 February 1901, p. 7.
66 ibid, 27 February 1901, p. 7 and 28 February 1901, p. 7; Cox Papers, Chart of War Service of officers of 3rd N.S.W.M.R.
67 Sydney Morning Herald, 19 January 1901, p. 9 and 30 January 1901, p. 7. 
to excellent raw material. J. See, the New South Wales premier, claimed that he had been told by "competent judges" that the contingent from his state "was equal, if not superior to any of its predecessors". 68

The farewell parades were relatively quiet affairs. But press editors and politicians still said complimentary things about what was widely regarded as another Imperial contingent, "invited by one of the greatest commanders in the British army". ${ }^{69}$ Out of all the utterances emerged a common idea, however. The men of the fifth contingent had only to protect a military reputation that had already been won by the earlier contingents.

The keenness of Australians to serve in South Africa was evident in ways apart from the raising of the draft contingents. A representative of the Houlder Line, shippers of remounts to South Africa, revealed that the company had been "besieged" by men wishing to work their passages to the Cape, and that "upwards of 500 men" had been taken under those conditions already, with the object of joining South African irregular regiments on their arrival. ${ }^{70}$ And at the same time as the fifth contingent was being raised in Victoria, agents of the Marquis of Tullibardine recruited 250 Victorians of Scottish descent to serve in the Scottish Horse, a regiment of irregular cavalry which the Marquis raised and led himself.

Direct recruiting within Australia for a British regiment created some resentment, however. The mayor of Melbourne, who was also president of the Caledonian Society, addressed a letter to the Age in which he dissociated himself from the Scottish Horse because he thought Australians should go in Australian regiments and preserve their identity. ${ }^{71}$ And the Victorian

\footnotetext{
68 ibid, 7 March 1901, p. 7.

69 ibid, 18 March 1901, p. 5.

70 ibid, 2 February 1901, p. 9.

7119 January 1900, p. 9.
} 
commissioner for railways announced that only those employees who joined "distinctly Victorian" contingents would have their positions kept for them. ${ }^{72}$ Even sterner opposition resulted when Milner suggested that officers of Baden Powell's South African constabulary might be allowed to recruit 1,000 men in each state. The Sydney Morming Herald rejoiced that the request had received "a point-blank negative" from Australian authorities. The paper drew a very uncertain distinction between sending volunteers to help fellowsubjects threatened with invasion, and transforming Australia into "a happy hunting-ground for the recruiting sergeant". ${ }^{73}$ Australia had in fact long since become a reservoir of recruits for the War office, with enlistment being greatly facilitated by "recruiting sergeants" like Philp and McCulloch. And the supply seemed inexhaustable, as was to be shown when the Commonwealth contingents were raised early in 1902.

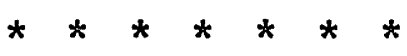

As 1901 progressed, the war in South Africa plunged further into the depths of inhumanity and agony. Kitchener stepped up his policy of laying waste to the land, and the women and children that his soldiers tore from their doomed farms died in increasing numbers in concentration camps. To these desperate strategies he added another, which aimed at destroying the marauding bands of Boers who contined to menace the 250,000-strong British army with waspish attacks. The black-house system was introduced. This initially entailed the construction of fortified posts at intervals along

72 Sydney Morning Herald, 6 March 1901, p. 7. The Federal and Victorian governments went along with the Scottish Horse recruitment, with the Victorian government prepared to take responsibility for medical, riding and shooting tests only. - Age, 2 February 1901, p. 10.

7319 February 1901, p. 4. South Australia was the one state inclined to co-operate, but only to the extent of 100 recruits.-Sydney Morning Herald, 21. February 1901, p.7. 
railway lines, but later the space between was closed with barbed wire to form great fences. Long lines of horsemen were then used to drive the enemy into the fences like fish into a net. For this operation and for generally chasing the enemy about the veldt, Kitchener wanted more and more mounted troops. And he wanted them quickly, for the protracted war was causing humiliation to the hero of Khartoum.

The manner in which Australia was drawn further into the conflict demonstrates the power of a few individuals when backed by the press.

The sequence of events which ended in Edmund Barton's capitulation to a few voices who were motivated by God knows what, began on 9 December 1901 with the publication in the Australian press of a London account of German criticism of the colonial war effort. The German press was reported as saying that Australia's disinclination to send more troops to South Africa showed that England would find her colonies a broken reed to lean upon in times of trouble. It also considered that the military ardour of the British colonies had vanished as soon as they found that war was no nursery game. ${ }^{74}$ On the same page the newspaper reported that a Canadian offer of 900 men had been accepted for service in South Africa.

On 10 December the Age and the Argus published a letter from McCulloch (who had lost his defence portfolio to the higher legislature), calling for a Commonwealth troop offer of 5,000 men, as an answer to the "broken reed" jibe. ${ }^{75}$ On 12 December it was reported that See of New South Wales did not support McCulloch's call but two other premiers, Peacock of Victoria and Philp of Queensland, did. Barton was reported as saying that the state of affairs in South Africa did not warrant more troops, but if they

74 Daily Telegraph, p. 5. For a far less provocative translation see C. of A. P.D., 1901-2, Vol. 7, p. 8740 .

75 Mentioned in the House of Representatives by Barton. - C. of A. P.D. Vo1. 7, p. 8741. 
were requested by the Imperial authorities the government would consider the matter. ${ }^{76}$

The case for further Australian commitment began to build up. The Daily Telegraph called for an offer of another contingent to silence German detractors, and noted that a New Zealand contingent of 1,000 men was to go. ${ }^{77}$ The following day it reported the warm praise of the English press for the colony's patriotic offer. ${ }^{78}$ On 18 December the Victorian Legislative Assembly passed a motion, "that this house expresses the hope that the Federal Government will offer, unasked, the services of an Australian contingent for South Africa". 79

Also on 18 December, McCulloch wrote again to the press, mentioning the Canadian and New Zealand offers and wishing that "we had at the head of our Commonwealth someone with sufficient backbone to rise to the occasion". 80 But it was his next move that really brought results. Although the press did not get on to the story for some days, McCulloch breakfasted in Melbourne with Henniker Heaton of the House of Commons. Following their discussion the British M.P. cabled Chamberlain:

Mr. McCulloch, Victorian Minister, asks me to inform you that he will undertake to equip and dispatch within one month a thousand good riders and shots (the majority of whom have already served in South Africa) with their horses, from Victoria, if you will wire Sir John Forrest to that effect. ${ }^{81}$

76 Daily Telegroph, p. 5. Philp said that Barton should have offered men long ago because "What they want to end the war is a lot of Australians". - Brisbane Courier, 12 December 1901, p. 5.

7716 December 1901, p. 4.

78 p. 5 .

79 V.P.D., Vol. 99, pp. 3680 ff. John Murray opposed on the grounds that the war was now being conducted against Boer women and children, but received a tirade of abuse from interjectors who regarded his statement as "shameful" and "terrible" and called on him to withdraw 1t. - p. 3688.

80 Daily Telegraph, p. 7. An Age editorial also castigated Barton. - 19 December 1901. p. 4.

81 Daily Telegroph, 25 December 1901, p. 5. Forrest was the Federal minister for defence. 
On 21 December Barton received a request from Chamberlain for 1,000 men with the Imperial government meeting all costs. ${ }^{82}$ Sections of the press were convinced that Heaton's cable, and Chamberlains misconstruction of it as involving the Federal government, led to the request for troops. ${ }^{8} 3$ Barton himself seemed to accept the awful truth when, in an interview with the Advertiser, he blamed "intermeddling" persons for the request to Australia for only 1,000 men when the people obviously wanted to send a larger contingent. 84

Parliament was in recess when Barton received Chamberlain's request but cabinet promised compliance without delay. The prime minister obviously feared the wrath of the press more than he feared the Labour party which kept him in office and which had allegedly extracted a promise from him that he would take no action regarding more forces for South Africa without parliamentary sanction. ${ }^{85}$

Another pressure that had been constantly exerted upon Barton to commit Australia further was the attitude of the state premiers led by Peacock of Victoria. Peacock was happy to divulge to the press the details of a telegram to his colleagues which attacked Federal "hesitation" and stressed the need for a show of Imperial loyalty for the benefit of continental powers. He asked each premier to bring pressure to bear on Barton, and sought support

82 C. of A.P.D., Vol. 7, p. 8740.

83 Daily Telegraph, 25 December 1901, p. 5.

8428 December 1901, p. 8.

85 See Brisbane Courier; 1 January 1902, p. 4., Age; 25 December 1901, p. 4. Daily Telegraph; 15 January 1902, p. 6. 
in raising a contingent should the prime minister not act. All states but New South Wales agreed, and each telegraphed Barton with a request for action, but the scheme was forestalled by Barton's response to Chamberlain's cable. There could be no doubt, however, that Peacock had gone "within an ace of raising military forces in flat violation of the Federal Constitution". ${ }^{86}$ Barton's eventual action on a contingent pleased none of his critics. The conservative press widely bemoaned the ignominy of Australia's having to be asked to help the Empire. The Bulletin was a little more understanding. A full-page cartoon depicts a miniature McCulloch dancing gleefully at the feet of a sombre Barton who scans a sheet listing the evils of militarism. ${ }^{87}$ The same paper also referred to the new force to be raised as the "Henniker Heaton Federal Cohentingent", ${ }^{88}$ and printed a poem by Victor Daley which expressed a view of the war which none in the corridors of power could see or wanted to see. Entitled "More Troops", its last verses ran:

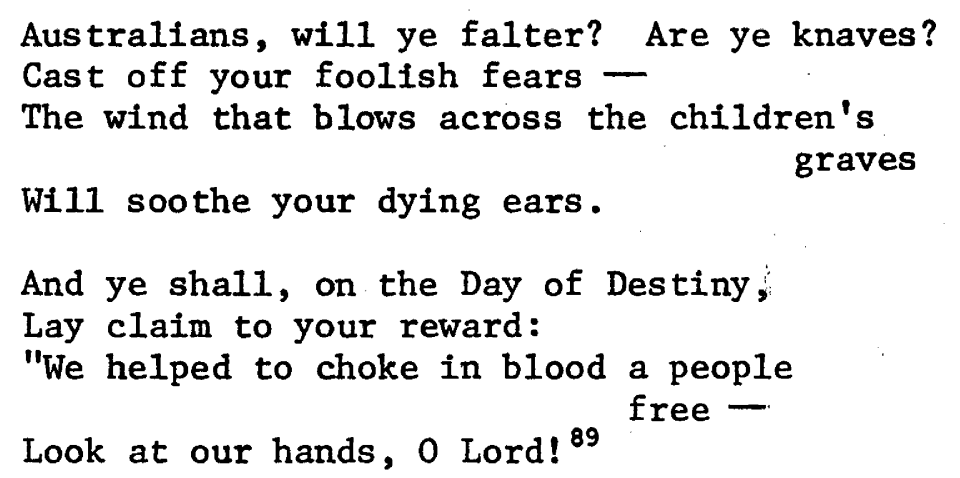

\footnotetext{
86 Daily TeZegraph, 25 December 1901, p. 4.

8728 December 1901, p. 17.

8811 January 1902 , p. 7.

8928 December 1901, p. 7.
} 
On 14 January 1902, Barton brought before the House of Representatives a two-part patriotic motion, and when he spoke in support it was obvious that his concern was to placate at one and the same time the powerful critics who had questioned his leadership and loyalty, and Labour parliamentarians who had wanted any decision on more troops to be a matter for debate in the legislature. 90

To excuse his earlier inaction, Barton insisted that the Home government had created a clear precedent by asking the Australian colonies to raise the third, fourth and fifth contingents. Therefore it followed that when more troops were needed for South Africa, the Inftiative would come from England. So Barton had walted and when the call from the mother land did come, that was suffictent reason for cabinet to decide on the dispatch of a Commonwealth contingent without reference to parliament, which was adjourned at the time. 91

The remainder of this first and last federal debate on the war was Empire all the way. The only significant speech against the motion was made by H.B. Higgins, and although he still opposed Australian involvement on "the simple old-fashioned ground of justice",92 his love of Empire was as feelingly vouched for as his regard for justice for the Boers. ${ }^{93}$

The first part of the motion was resolved in the affirmative without division, and the second part was carried by 45 votes to $5 .{ }^{94}$. So after two years of a war which had lost most of its overt public support, and which

90 The first part of the motion expressed "indignation at the baseless charges made abroad against the honour of the people and the humanity and the valour of the soldiers of the Empire"; the second part affirmed "the readiness of Australia to give all requisite aid to the mother country in order to bring the present war to an end". - C. of A.P.D., 1901-2, Vo1. 7, p. 8739 .

91 ibid, pp. 8739-47.

92 ibid, p. 8753.

93 ibid, p. 8759.

94 ibid, p. 8799. 
had lapsed into a shabby affair begging for able critics, only five men in the parliament of the new federation stood up to be counted.

The second part of the resolution not only supported executive action in authorizing the first Commonwealth contingent; it also cleared the way for further military commitment. And Barton, smarting from the personal attacks of the previous weeks, was only too ready to implement the resolution; especially as the mother land called, and called again.

On 21 January, he announced to the House that Chamberlain had asked for another 1,000 men and that the Commonwealth government would cable compliance without delay. 95 And on 20 March he told the House that his government would meet as quickly as possible a request for a further 2,000 Australians.96 England had learned by this stage that to ask was to receive.

$$
* * * * * * * * * *
$$

Within five months of receiving the first request for troops on 21 December 1901, the Commonwealth government raised and embarked 4273 men in three contingents. The federal forces were called the Australian Commonwealth Horse, and their members carried the initials "A.C." on their shoulder straps, hopefully to emphasise the unity and identity of battalions drawn from all states. Not that the Commonwealth authorities had originally envisaged an integrated federal army corps, however. When Barton met the military commandants on 30 December, it was decided to raise nine units of 120 men for the first Commonwealth contingent. ${ }^{97}$ And captivated by the idea

\footnotetext{
95 ibid, p.8954.

96 ibid, Vol. 8, p.11,099.

97 Daily TeZegraph, 31 December 1901, p.5.
} 
that small Australian units in South Africa had become the eyes and ears of the army, Barton inquired of the Home government whether the A.C.H. would be similarly employed. Chamberlain's wish, however, was that the Australians form two battalions..$^{98}$

Recruiting for the Commonwealth contingents proceeded on lines laid down by the Imperial authorities. Volunteers were to be able to ride and shoot, with preference going to men with previous South African experience. Single men only were to be enlisted. Rates of pay were $1 / 2$ a day prior to embarkation and 5/- thereafter. The Imperial government undertook to reimburse the Commonwealth for all equipment costs, and to provide arms and transport. ${ }^{99}$

The ranks were quickly filled. New South Wales, which with Queensland formed the first battalion, recruited her 350 troopers from over 2,000 volunteers. Of these 170 were returned men. ${ }^{100}$ And 13 of her 15 subalterns had served in South Africa as officers or N.C.0.'s.'101 Victoria, which provided the bulk of the second battalion, raised a force of veterans. of the 350 men attested, 230 had fought in South Africa, as had 21 out of 24 officers. Recruits were drawn principally from the lower socio-economic group. 102

The number of veterans able and willing to return to South Africa was limited, however. They formed a minority of the third and fourth battalions, which made up the second Commonwealth contingent, and were even more poorly represented in the four battalions that formed the third conting-

98 ibid, 4 January 1902, p. 11.

99 C. of A.P.D., 1901-2, Vol. 7, p. 8740 .

100 Daily TeZegraph, 24 January 1902, p. 8.

101 ibid, 31 January 1902, p. 9.

102 Major-Gn1. Sir J. Bruche Collection, A.W.M., "Victorian Units and Staff of 2nd Battalion, 1st Commonwealth Contingent". 
ent. 103

The War office had not stated any preference for bushmen in its call for more Australians, but the type was still favoured by local authorities, ${ }^{104}$ and the organisation of the third and largest Commonwealth contingent on a territorial basis directed recrulting activity entirely to the country. Each squadron was raised within bounds that usually coincided with the area from which a mounted regiment was recruited. In New South Wales, for instance, the four squadrons that formed the fifth battalion were drawn from country districts associated with the New South Wales Lancers, the New South Wales Mounted Rifles and the Australian Horse.

The departure of the three Commonwealth contingents in February, March, and May of 1902 indicated the negative attitude of the public towards the war in its final stages. Public demonstrations did not occur; and governments did nothing to promote them. For example, the first battalion embarked in Sydney at short notice and without benefit of a procession. 105 The Queensland members of the same battalion were farewelled from a Brisbane railway station at 6.45 a.m. on Sunday morning. ${ }^{106}$ The South Australians marched to the docks at $8.00 \mathrm{a} . \mathrm{m} .{ }^{107}$ And the Victorian squadrons embarked without any show of pomp or ceremony. 108

It is difficult to say whether the Commonwealth troops were victims of apathy or antipathy as they marched to the docks through undemonstrative streets. There is good reason why the latter emotion should have prevailed,

\footnotetext{
103 A detailed nominal roli of the eighth battalion, held by the State Library of Tasmania, shows that only 60 recruits in a force of 500 men were veterans.

104 Brisbane Courier, 24 January 1902, p. 5; Advertiser, 7 January 1902, p. 5; Daily Telegraph, 6 January 1902, p. 5, and 25 January 1902, p. 5.

105 Daily Telegraph, 18 February 1902, p. 6.

106 Brisbane Courier, 27 January 1902, p. 4.

107 Advertiser, 21 February 1902, p. 5.

108 Age, 13 February 1902, p. 5.
} 
because in the last months of the war the inhumanity and ferocity of the conflict were made quite evident. And the message did not come only from the radical press. The Brisbane Worker might publish details of Emily Hobhouse's investigation of the concentration camps, ${ }^{109}$ and the Bulletin might thunder about "the slaughter of the children", 110 but no less strident was the Daily Telegraph's simple statement of the appalling concentration camp statistics. 111

The publication of letters from the front also played a part in revealing to the Australian public the unheroic character that the war had assumed. Newspapers opposed to the war naturally printed the most lurid accounts of destruction and rapine, but the Daily Telegraph, demonstrating its growing disenchantment with the military adventure, published one of the most damning letters received from men in the field. Written by a sergeant of the fifth contingent, and featured under the heading of "Looting and Burning of Farm Houses", it gave details of the worst aspects of the war.112 With the war proceeding in such a fashion, it was likely that the anti-war movement which developed late in 1901 would have gained considerable support, but this was not so.

The Anti-War League was formed in New South Wales in January 1902 under the influence of W.A. Holman and Professor G.A. Wood, and its first significant act was a meeting of some eighty members at which a petition was prepared calling on the House of Commons to discontinue the war, and to accord to the enemy an honourable peace with compensation. ${ }^{113}$ The petition had little

\footnotetext{
10924 August 1901, p. 6.

1105 October 1901, p. 9.

11121 0ctober 1901 , p. 5. In September 447 adults and 1,964 children died out of a total of 55,092 adults and 54,326 children held.

11224 August 1901, p. 9.

113 Daily Telegraph, 31 January 1902, p. 8. Victor Daley and A.G. Stephens were appointed to lead a literary committee aimed at combating "the dense ignorance" of the public.
} 
success, however. The New South Wales political Labour conference rejected by 36 votes to 35 a motion that the president sign on its behalf. ${ }^{14}$ Many shire and municipal councils treated the petition with derision when its organisers asked that it be placed where it might receive signatures. ${ }^{115}$ The Victorian Labour party declined to sign the petition, and just prior to its closure the appeal could only boast 1,026 signatures in New South Wales. ${ }^{116}$ H.B. Higgins's petition to the Australian parliament on 21 January was also poorly supported. It sought the withdrawal of Australian troops and a just peace for "a brave and gifted foe". 117 According to one report, the petition carried about 800 signatures and was received by the House in complete silence, while Barton's announcement on the same day of the Imperial request for another 1,000 troops was greeted with cheers. ${ }^{118}$

Another embryonic movement was the Peace and Humanity Society in Victoria. At a "well attended"meeting in Melbourne, chaired by the Rev. Dr. Rentoul, Presbyterian minister and outspoken critic of the war, motions were passed condemning the Federal government for sending more troops, and denouncing the press for its support of the war. 119

Despite the limited success of these intellectual peace movements, they did mark the beginning of a public reaction against the middle class view of the war. They would probably have gained in strength had the war continued, for there were signs that the ordinary people were prepared to take a stand. A public meeting at Goolagong passed a vote of confidence in W.A. Holman, the local member and the most active opponent of the war in

114 ibid, 1 February 1902, p. 11. But the same body three days later carried by 39 votes to 25 a resolution seeking much the same things as the petition sought. - ibid, 4 February 1902, p. 8.

115 ibid, 5 April 1902, p. 9, and 16 April 1902, p. 7.

116 H.V. Evatt, Australian Labour Leader, (Sydney, 1940), pp. 144-5.

117 C. of A.P.D., 1901-2, Vol. 7, p. 8954.

118 Advertiser, 24 January 1902, p. 4.

119 Age, 12 Apri1 1902, p. 11. 
Australia, and expressed sympathy with the objects of the Anti-War League. 120 While the congregation of Kiama Catholic Church signed a petition to stop the war. ${ }^{121}$

The most powerful voices in the land, however, were still espousing the Imperial cause, although they did this at the great patriotic demonstrations held to affirm Australia's faith in the British government's conduct of the war, ${ }^{122}$ rather than at the farewells to the Commonwealth contingents. The Empire, after all, was a greater and more durable thing than Australia's citizen soldiers, whose sun was already setting.

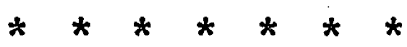

of the troops who followed the first and second contingents to South Africa, it was the Bushmen who made a significant contribution to Australian military tradition. The third contingent, the Australian Bushmen, landed at Beira in Portuguese East Africa in April 1900, and made their way. up through fever-ridden country to join Sir Frederick Carington's Rhodesian Field Force at Bulzwayo. Within two months the fourth contingent, the Imperial Bushmen, also joined Carington, to make Australians the most numerous component of the R.F.F.

The objects of the force were to protect Rhodesia against the possibilities of Boer invasion and native uprisings, but with Roberts' capture of Pretoria the Transvaal commandos had chosen the disperse to east and west instead of across the Limpopo. And to assist in containing Boer activity in Western Transvaal, Carington was ordered to the area. The greater

\footnotetext{
120 Daily TeZegroph, 10 March 1902, p. 5.

121 ibid, 18 March 1902, p. 5.

122 ibid, 11 February 1902, p. 7; 19 February 1902, p. 7; 21 February 1902, p. 5 ; and 22 February 1902 , p. 10. The meetings were largely prompted by Continental criticism of Britain.
} 
part of the service of the Bushmen was in this locality, although sections of them came under British commanders other than Carington. For the twelve months that the two contingents were in South Africa, the Bushmen threw themselves into the skirmishing of the guerrilla phase of the war with a dash and gusto which was so alien to the usual British methods that the Boers sat up and noted the advent of a new type of enemy. Military operations at the time were directed equally at the civilian population. There were farms to be burnt, crops to be destroyed, livestock to be confiscated, and families to be taken into custody; and there is every reason to believe that the Bushmen applied themselves to this aspect of war with the same dash and gusto. The first action involving the Bushmen was the relief of Mafeking. One hundred dismounted Queenslanders hurried out of Rhodesia by train and by forced march as escort to a Canadian battery, but were denied a significant part in this glamour event because they arrived just as the siege was being lifted. In the brief time at their disposal, however, the Bushmen did reveal the brash fighting style that was to be their chief claim to fame. The Queenslanders had been given a subordinate position as support to a force of Fusiliers, but as the British regulars moved forward against the enemy they heard fiendish yells and found the Bushmen were with them, not behind them. A contemporary historian stated that the Fusiliers could have been forgiven for thinking that "the Great White Queen had let loose upon the foe a battalion of Red Indian soldiers"; but he also considered that the Australians, who exposed themselves outrageously, would have been killed to a man by a disciplined enemy. 123

123 Cassell's History of the Boer War, Vol. 2, p. 182. 
While the build-up of Australians in the Western Transvaal was still proceeding, two small and successful engagements fought by units of the Bushmen brought further recognition of their vigorous methods. A force under Colonel H.C.O. Plumer, an Imperial officer, took the town of Zeerust by employing what was said to be "a highly novel and original method of warfare", namely, charging the Boers on horseback and dragging them off their horses. 124 And Rustenburg was captured by 900 Bushmen, again led by an Imperial officer, in a skirmish that won the praise of Colonel Baden Powe11.125

Within a fortnight of these successes, however, disaster befell a force of 300 Australian Bushmen from four colonies led by H.P. Airey, an old, ex-Imperial man who had been serving with the permanent artillery in New South Wales. Airey's command had been sent out from Rustenburg to help escort a large convoy from Elands River camp, but on 23 July they were attacked by a commando under General Lemmer at Koster's River. The Boer force was estimated at 400 , but it increased during the day to about 1,000 . The Australians were pinned down by rifle fire from a horseshoe of hills, and while they were able to take reasonable cover themselves, their horses were so exposed that over 200 were killed or stampeded. In the heat of the engagement an isolated group of ten men hoisted a white flag; and a couple of hours later Colonel Airey decided to surrender as a matter of honour, for he considered that the white flag had compromised the entire position.

Major Vialls of Western Australia, who commanded part of the force, refused to comply, however, and the Bushmen held on until darkness fell and Lemmer's men withdrew before the approach of another British force. They had lost 6 killed and 22 wounded. 126 Vialls was eulogised in the Western Australian

124 Macdonald, "A History of Australian Contingents in the South African War", in Harding, War in South Africa, p.649.

125 James Green, The Story of the Bushmen, (Sydney, 1903), p.78. Another account noted that the Bushmen charged in "the dare-devil manner peculiarly their own".- Casselz's History of the Boer War, Vol. 2, p.423. 
legislature for having disregarded the shameful order. A member even considered his action as "parallel with that of Nelson both in its intent and its effect".127 But J.C. Smuts, who was leading a commando in the area at the time, could only heap scorn on the Australians. 128

Even as Airey's men made their way back to Rustenburg, the stage was being set for the most significant engagement fought by the Bushmen during the war. This was the siege of Elands River camp, and Smuts honoured it as the occasion on which the Boers were taught an appreciation of the fighting qualities of Australian soldiers.129

On 4 August a force of 2,500 - 3,000 Boers under Generals de la Rey and Lemmer attacked a stores depot guarded by fewer than 500 colonials. One hundred New South Wales Bushmen, 150 men of the Queensland Mounted Infantry, 75 Rhodesians and smaller numbers of Victorian and Western Australian Bushmen made up the British force. Anticipating an attack but hoping that a column under General Carington would arrive before it eventuated, the colonials had improvised a defensive position out of ox waggons and boxes of stores. This precaution saved the camp, for in the first two days of the siege over 2,500 shells from nine pieces of artillery were poured onto the compound, killing most of the 1,500 horses, oxen and mules, scattering stores, and taking toll of the defenders.

On the second day of the investment, Carington came into view with a mounted force of 1,000 men, made up equally of the New South Wales Imperial Bushmen and South African irregulars. But the cheers of the defenders were short-1ived for Carington, employing no scouts, rode into an ambush and was

127 W.A.P.D., 1900, p.2085.

128 Selections from the Smuts Popers, Vo1. 1, p.586. Smuts compared the brash and confident attitude of the Australians before leaving Rustenburg with their crestfallen demeanour when they returned, "hatless, breathless and with bleeding feet".

129 ibid, p.588. 
soon in headlong retreat towards Zeerust.

By this time the garrison had completed its defences, burrowing into the rocky ridge on which the camp was situated with nothing but picks and shovels. The mining experience of some of the men helped greatly, but the main reasons for success were a determination not to surrender and a capacity to labour long and hard. The situation for the defenders was also improved after the second day by a considerable reduction in the rate of bombardment, possibly because of the damage to stores that de la Rey needed badly. But the fight was kept going at a hot pace by small arms fire by day and by night, when small parties of Australians and Rhodesians ran the gauntlet to fetch water from the river half a mile away.

On the seventh day of the siege, de la Rey invited the camp to surrender. In recognition of "the gallant defence" that had been made he was prepared to allow the officers to retain their arms, and he guaranteed a safe passage for the entire force to the nearest British position. Colonel C.0. Hore, the Imperial officer commanding at Elands River, declined the offer (although later rumours attributed the refusal to surrender to the attitude of some of Hore's subordinate officers).

In the meantime Colonel Baden Powell had moved towards the besieged position with a force of 2,000 men, including a large number of Bushmen; but when within twenty miles of the camp, he turned away on orders from Roberts, who had been advised by Carington that the garrison had capitulated. A lone rider whose name is lost to history got through the Boer lines, however, and alerted Mafeking to the true state of affairs. On 15 August, the Boer forces withdrew as Kitchener's column of 10,000 men approached, and early next morning the commander-in-chief rode into camp to praise the colonials for "a wonderful defence". Imperial and colonial officers walked around the carcase-strewn ridge and marvelled at the extent and efficiency of the 
improvised fortifications. ${ }^{130}$ The twelve-day defence had cost the colonials

12 dead and 38 wounded, and seven Kaffirs had also been killed. ${ }^{131}$

The action at Elands River won wide praise for the defenders. An assessment of the action by J.C. Smuts is the most significant.

Never in the course of this war did a besieged force endure worse sufferings, but they stood their ground with magnificant courage. All honour to these heroes who in the hour of trial rose nobly to the occasion, and amid retreats and flights and capitulations, shed a glory all their own on the brief comic page of Baden-Powell's occupation of the Western Transvaal. 132

Strangely enough, the Australians were not widely acclaimed in their own land despite the comprehensive reports of the action by the Rev. James Green. Perhaps this was because editorial comment failed to emphasise the event. Perhaps it was because war-fever had subsided. Or perhaps it was because Australians had already accepted their soldiers as heroes. The noted balladist, George Essex Evans, did see something distinctive in the engagement, however, and he honoured it in verse.

We saw the guns of Carrington come on and fall away; We saw the ranks of Kitchener across the

For the sun was shining then kopje gray,

Upon twenty thousand men,

And we laughed, because we knew, in spite of hell-fire and delay,

On Australia's page for ever

We had written Eland's River -

We had written it for ever and a day. 133

130 Sydney Moming Herald, 9 October 1900, p. 3, and 23 October 1900, p. 5, Reports of James Green, Methodist chaplain, who was with the Bushmen at Elands River.

131 Boer War Diaries and Letters of F.V. Weir, MSS. 1024/1, M.L., Diary entry of 16 August, 1900.

132 Selections from the Smuts Papers, Vol. 1, p. 593.

133 This transcript of the poem was quoted by a Bushman diarist in John Bufton, Tasmanians in the Transvaal War, (Hobart, 1905,) p. 160. 
The reverse side of the Elands River coin was the retreat of Carington's force. There was nothing shameful about the British general's withdrawal of his untried column from an ambush executed by a force of Boers superior in number and commanded by the most competent Transvaal soldier. What was shameful was that Carington kept on running, and without a good reason. When he extricated himself from the ambush, having suffered seventeen minor casualties, he made for Zeerust by a series of forced marches, firmly believing that a formidable portion of the Boer army was in pursuit. The Boer force that was tailing him, in fact, amounted to fewer than 100 men. This, of course, was a further indictment of the poor scouting of the British force.

Carington only stopped long enough in Zeerust to attempt to burn all British stores, before continuing his flight towards Mafeking. However, he was soon ordered back to Zeerust by Roberts, who was not amused by the series of blunders in Western Transvaal. From there he was sent back to Rhodesia, leaving the Australians of his command in the hands of more capable leaders.

The Rev. James Green came across a number of Carington's Impertal Bushmen after the retreat and found them in a state of some shame, although they claimed that they had known little of what was really going on. ${ }^{134}$ But the damage had been done, and contemporary reports from both sides were highly critical of the inglorious retreat. ${ }^{135}$

The London cables, however, which supplied most of the Australian newspapers with exaggerated and partisan reports of the most routine engagements, were able to turn the debacle into a dogged withdrawal, in which the

\footnotetext{
134 Sydney Morning Herald, 23 October 1900, p. 5.

135 Selections from the Smuts Papers, Vo1. 1, p. 592; James Green, "The Siege of Eland's River Camp", in Barton, The Story of South Africa, pp. 483-4.
} 
Imperial Bushmen distinguished themselves by admirable scouting and skirmishing. 136

The Bushmen of the third and fourth contingents were only involved in three other skirmishes of any significance before they returned home. The first of these was at Rhenoster Kop, north of Pretoria. Late in November, Plumer led a force of 1,000 irregular infantry and 1,000 Australians and New Zealanders against a comparable Boer force. A brisk one-day fight ensued in which the British side lost 100 men killed or wounded. The Boers withdrew at night because a larger British force was approaching. Plumer's men put up a good showing, but it was the New Zealanders who so distinguished themselves that Lord Milner was prompted to cable his congratulations to the New Zealand premier. 137

The Bushmen were not be be subordinated in their next fight, however. In February 1901, a number of Australian units of the second, third and fourth contingents joined with British regiments in the greatest of the three "hunts" after De Wet. But it was Plumer's column of Imperial Bushmen, Queensland Mounted Infantry, and King's Dragoon Guards that put up the best show of endurance and dogged pursuit.

De Wet had moved into Cape Colony in a desperate attempt to secure advantage for the sorely-pressed Boer forces by stirring up disaffection among Dutch settlers. Two other Boer columns had preceded him, but so formidable was the reputation of the Free State general that all British forces available in the area were directed to halt him and turn him back across the Orange river.

On 13 February, Plumer's column engaged De Wet on a line of kopjes and turned him, "the Australian Bushmen with great dash carrying the central

\footnotetext{
136 Argus, 16 August 1900, p. 5.

137 Conan Doyle, The Great Boer War, pp. 404-6.
} 
kopje". De Wet then made to the north-west but could not shake off Plumer. For a week, in rain and hail, "the two sodden, sleepless, mud-splashed little armies swept onward over the Karoo", until the Free Staters were halted by the flooded Orange river. Plumer hit again and took 100 prisoners, but De Wet slipped along the river looking for a crossing. He had acquired fresh horses from another commando, while Plumer's men were riding the same mounts, which were dropping dead under their riders. The Boer force eventually found a ford and crossed into the Orange Free State, minus its guns, its convoy, about 1,000 horses and 300 men. 138

After the De Wet hunt, virtually all the third contingent Bushmen fit for action came under the command of Plumer, and were utilized in an advance from Pretoria north to Pietersburg. But this force of 600 seasoned men encountered little resistance. Even Pietersburg was taken with ease, although three Bushmen, two officers and a trooper, werekilled by a Boer concealed in long grass before he was riddled with bullets by angry Australians. 139

Further proof of the dash of the Australian horsemen was given at Hartebeestefontein in Western Transvaal on 21 March, when a force of New Zealanders and Imperial Bushmen under Colonel Raleigh Evans of the Inniskilling Dragoons carried out an old-fashioned charge against Boer positions. According to one historian, the attack was foolhardy but proved "that a charge of mounted troops in open order was one of the best methods of demoralising the enemy". 140 Another writer described the charge: "With wild cheers the New Zealanders and Bushmen raced down on their foes ... and the whole force fled

138 ibid, pp. 431-3.

139 Green, The Story of the Bushmen, pp. 212.

140 Macdonald, "A History of the Australian Contingents in the South African War", in Harding, War in South Africa, p. 684. 
terrified before the furious charge". 141

The episodes described above formed a minor part of the work of the Bushmen, however. Most of their time was spent in implementing the scorched-earth policy of first Roberts, and then Kitchener. Some of the men involved gave blunt accounts of the operations.

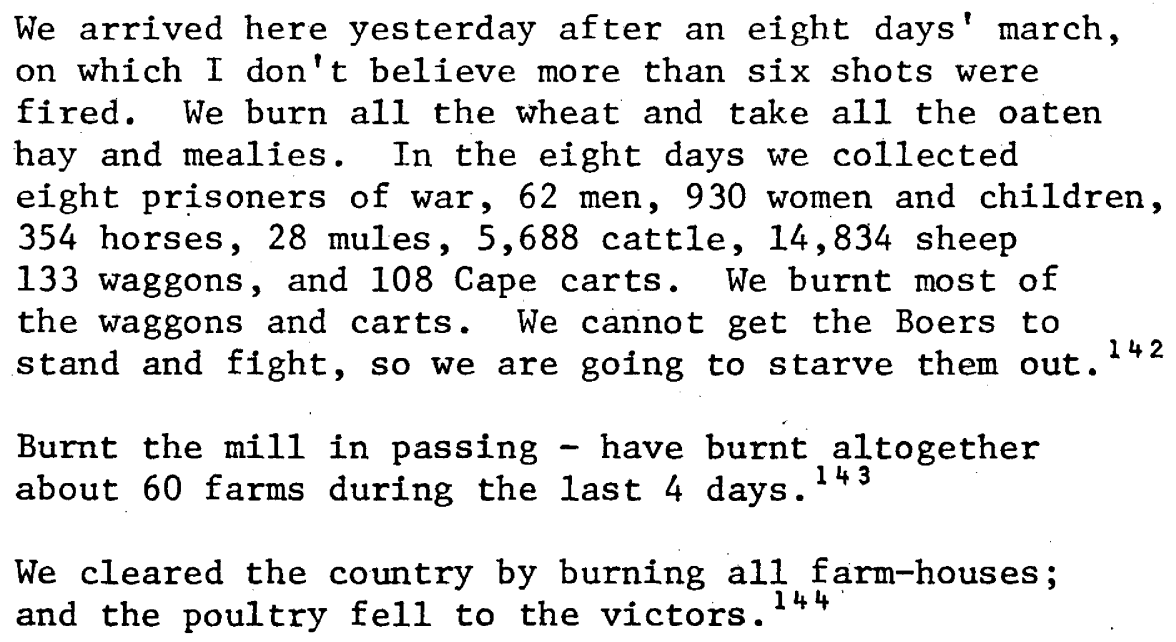

Like their compatriots of the first and second contingents, the Bushmen were keen to return home when they had completed twelve months' service in South Africa. Plumer's biographer tells of "signs of incipient mutiny" when the Australians were ordered out on trek just before their time was up. General Paget spoke to them without effect, but Plumer, who had won their affection and respect with his competence and quiet personality, was greeted with cheers when he told them that both he and they would parade next morning. 145

\footnotetext{
141 With the Inniskilling Dragoons, p. 240.

142 Sydney Morning Herald, 16 January 1901, p. 7. Letter from Sgt. Tom Thoms on, Imperial Bushman.
}

143 Extracts from Diary of Major Walter Blake Nisbet, M.B., Ch.M., 4th Queensland Bushmen, M.L., Entry of 3 November 1900.

144 Major R.C. Lewis, O.C. Tasmanian Imperial Bushmen, On the Veldt, (Hobart, 1902), p. 123.

145 General Sir Charles Harrington, Plumer of Messines, (London, 1935) p. 49 . 
Some of the Bushmen stayed on in South Africa and, supported by reinforcements from the draft contingents, carried the name of the corps through to the end of hostilities. The achievements of the Bushmen were so uneven that it is difficult to generalise on their worth. But most people who observed them in the field, if asked to describe the corps in a phrase, would have agreed with G.A. French that they were the "wild men" of the Australian contingents.

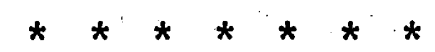

The fifth contingent was in the field by the middle of 1901 , but by that time the conflict did not merit the name of war. The Australians found themselves part of a mere police function, although they could hardly have expected anything more when they volunteered.

Private Otto Techow of the 6th W.A.M.I. kept a detailed diary of his experiences. It tells of a campaign that would have contributed little to the Australian military image. Certainly, the men had to endure great hardship. It was common to ride for the greater part of the night, frequently in bitter cold, in order to attack a laager or farmhouse at dawn. ${ }^{146}$ But usually the engagement was a trivial affair. On one occasion the column of 700 men, West Australians and regulars, found that they were surrounding a laager of 19 men when dawn broke. ${ }^{147}$ Another all-night march culminated in a dawn attack on a farmhouse which sheltered one sleeping Boer. ${ }^{148}$ Sometimes the phantoms materialised, however, and Techow tells of an engagement over four days against a Boer force reported to be 2,000 strong. Yet even

\footnotetext{
146 Diary, A.W.M., Entries of 29 June, $3 \mathrm{July}$ and $6 \mathrm{July} 1901$.

147 ibid, 29 June 1901.

$148 \mathrm{ibid,} 3 \mathrm{July} 1901$. These sunrise attacks gave the Australians a change to flourish their favourite weapon, the bayonet.
} 
this protracted action cost the British column only five killed and eleven wounded. 149

Fights against Boer commandos might have been rare, but the destruction of the resources of the two republics was a continuing process. Techow's observations, as unfeeling as they are laconic, reveal a grim situation.

Told off to escort waggon to kraal for mealies, kaffirs howled badly while we were taking them ... Up at 4.30 ordered to burn 3 farms - get geese and pigs with Boers watching from hill, get firewood from a grave ... Ermilo being burnt every house and store being set on fire ... amused myself by going to the farms and kraals for loot ... reached Amsterdam a nice little town which we burnt ... into Paullpietersburg which we destroyed and burnt ... broke up pulpit of church to boil dixie. 250

Very few Australians who left any sort of a record of their experiences in South Africa made any reference to sexual matters, but Techow was one who implied that there was something to be had down at the kraals in addition to mealies. "[We] had a great bit of fun down at a kraal after dinner", he wrote, "the girls being full of life".151 But this would have been an isolated episode in twelve months of uninspiring and unrewarding warfare. Techow apparently yearned for more heroic things, and his diary, in common with many others that came out of the campaign, included transcripts of exaggerated war verse.

Accounts of the work of the fifth New South Wales contingent, known as the 3rd N.S.W.M.R., Indicate thatTechow's version of the mode of warfare in 1901 was accurate. The potential of the New South Wales regiment

\footnotetext{
149 ibid, 3-6 October 1901.

150 ibid, Taken from various entries.

$151 \mathrm{ibid,} 7$ October 1901. Another Australian noted that the native girls were not so friendly, for when men of the 2nd V.M.R. chased naked Swaziland maiden/s (supposedly to find out if they spoke English), the girls squatted on the ground and pushed sand between their thighs. Alured Kelly, "Personal Account", p. 15.
} 
as a military stike force was considerable. With a strength of 2,000 men, it was a sizeable unit. It was commanded by Colonel C. Cox of the New South Wales Lancers, and many of its officers and N.C.O.'s were Lancers who had seen service in South Africa under Cox. It was brigaded with the Inniskilling Dragoons (as the New South Wales Lancers had been), and the column of which it formed an equal part was led by General M.F. Rimington, one of the most competent and dashing cavalry leaders of the war. But there was no real fighting to be had, and a return of operations for the last five months of 1901 shows how the column was expending its energies. In 153 days it trekked 1,814 miles in pursuit of elusive bands of Boers or on convoy duty. It had thirteen skirmishes in which five men were killed and nineteen wounded. It killed 27 Boers, wounded 15 and captured 196. In so doing, it expended 64,563 rounds of .303 ammunition and 1,761 horses. During the period, 114 mules, 388 horses, 17,989 cattle, 272 waggons and 214 carts were captured. No figure was given for the number of farms burned. 152

The disinclination of Australians to serve longer than twelve months in the field was evident among the men of the 3rd N.S.W.M.R., and a spokesman made his appeal to go home direct to the top. During an address to the Australians by the commander-in-chief, a trooper asked, "Mr. Kitchener. when are you going to let us blokes go home? You know we only signed on for twelve months". One could imagine the great man turning apoplectic had a British soldier asked such a question, but he had no doubt learned to accept Australian brashness. Just one more job, he promised, then you shall go. ${ }^{153}$ On 28 April 1902 the Australians withdrew from the column, leaving the Inniskillings to fight on alone. Rimington praised them highly, paying tribute to their dash, their steadiness in action, their alertness, and their

\footnotetext{
152 Cox Papers, Package 1.

153 ibid, Packet 2 .
} 
ability to endure privation cheerfully. ${ }^{154}$ These compliments recognised the best qualities of the Australian solider, but with the conflict about to end he still had not been tried in the crucible of war. He had not faced any Colensos or Magersfonteins.

There was one occasion, however, when an Australian unit of the fifth contingent was subjected to the full blast of war, but it was under conditions of great disadvantage and the result was humiliation rather than honour.

On 12 June 1901, 350 men of the 5th V.M.R., led by Major Morris, R.A., with the unit's O.C., Major W. McKnight, second in command, camped at Wilmansrust near Midd 1 burg in Eastern Transvaal. The force was making its way back to a column commanded by General F.C. Beatson, after failing to engage a small commando that was known to be in the area. At 7.30 p.m., as the men were settling down to sleep or to read mail that had just arrived from Australia, a force of 140 Boers, taking advantage of a poorly secured camp, launched an attack from point-blank range.

Within five minutes, 18 Australians were killed and 42 were wounded and the fight was over. Of the remainder, some 50 evaded capture by fleeing into the darkness. Those taken prisoner were released almost immediately, for the Boers had long since ceased to detain their captives because of lack of facilities. Over 100 horses were killed and about the same number taken as prizes of war. The remainder broke loose to die from their wounds on the veldt or to fall into the gleeful hands of some passing commando or column. 155 Lord Kitchener's report to the Australian government on Wilmansrust was merciful in its brevity. It merely gave the statistics of Australian

\footnotetext{
154 Watkins Yardley, With the Inniskilling Dragoons, p. 338.

155 Conan Doyle, The Great Boer War, pp. 462-3; Official History, Vol. IV, pp. 203-4.
} 
losses and claimed that the V.M.R. had been surprised by a superior force. 156 Barton acknowledged the rout as "a most regrettable disaster" but drew comfort from the fact that whatever the cause of the surprise the men acted with "heroic valour", 157 and the Duke of York cabled his admiration for the Victorians who had "so gallantly given their lives in the service of the Empire". 158

However, others were more critical of the conduct of the Australians in what was the most serious mishap to befall any overseas colonial force. Kitchener was reported to have "flushed with anger" when advised of the reverse for it represented to him a blunder in the midst of success. ${ }^{159}$ His biographer was particularly severe on the men who, he claimed, had "failed alike in vigilance and discipline", for in addition to their failure to secure the bivouac, they had not responded to the Imperial officer's attempts to rally them. 160

The accusation that the force showed little vigilance was not unfounded. The V.M.R. knew there were Boers in the area, and in fact they had been followed all day by a section of General Ben Viljoen's commando. Yet security arrangements for the night were nonchalant to say the least. The pickets, it appears, were too few and too casual, and the attacking force slipped past them with ease. Within the camp there was no measure of alertness, either, as men lounged around camp fires or read by candlelight, their rifles anywhere but at their sides. Such laxness on the part of both officers and men was understandable, however, and was a measure of the state

\footnotetext{
156 Daily TeZegraph, 19 June 1901, p. 7.

157 ibid.

158 ibid, 22 June 1901, p. 9.

159 Casselz's History, Vol. II, p. 744.

160. Sir George Arthur, Life of Lord Kitchener, (3 Vols. London, 1920), Vo1. 2 , p. 36 .
} 
of the war at the time. British columns could hardly be expected to maintain maximum security precautions when enemy activity was generally confined to daylight sniping by small bands of Boers.

Less excusable was the panic that possessed the Australians when they were attacked. A member of the Boer raiding force has left a detailed account of the affair which places the Australians in a very poor light. R.H. Schikkerling's narrative of Wilmansrust begins with the meeting of the war council of a commando of 150 men, and the council's unanimous decision to attack and loot the camp of the Australians. In the view of Schikkerling, the Boers exposed themselves to observation when it was still light and when within two miles of the camp. From there 150 horsemen moved past the pickets and halted about 800 yards out. Thirty men remained with the horses and the rest advanced on foot until within 100 yards of the Australians, when a shot signalled the beginning of the attack. A line of about 80 horses standing between the two forces took the first fire and within seconds were alf killed or maimed. Then the Boers rushed the camp, halting about 25 yards out to fire into a confused enemy. Had they stayed at that distance and continued the attack, the Victorians would have been annihilated, but the readiness of the men of the V.M.R. to surrender and the desire of individual Boers to get their hands on loot brought the engagement to a halt after no more than ten minutes fighting. In Schikkerling's words,

\begin{abstract}
The enemy was taken quite by surprise and was terribly panicky, firing far too high even at close quarters ... They now surrendered in big batches, and near the cattle kraal seven in a body surrendered to me alone. Some lay flat on the ground, afraid even to lift their heads ... Deeper in the camp I encountered three behind an ox wagon ...
\end{abstract}

For many a night after, the taking of the Australian camp was the sole topic of conversation among the elated Boers. ${ }^{161}$

161 R.H. Schikkerling, Commando Courageous, (Johannesburg, 1964), pp. 219-30. 
It was generally held that the victory at Wilmansrust raised Boer morale out of all proportion to the magnitude of the engagement. The two Boer governments met on 20 June to decide whether to continue the war, and although an exhortation from Kruger abroad to continue the war was a major factor in deciding the issue, any remaining disinclination was dispelled by the elation over the Australian disaster. 162

Australians generally and Victorians in particular would have been pleased to let Wilmansrust slip quietly into history, but the affair had an unfortunate sequel which served to bring the whole matter before the public gaze.

On 28 September 1901, the Age published a personal letter written by an un-named member of the 5th V.M.R. In it the soldier described an attempt by three Australians to incite their comrades to mutiny because General Beatson had described the defenders of Wilmansrust camp as "whitelivered curs". A photographic copy of a court-martial schedule included with the letter showed that a Private J. Steele had received the death penalty for his part in the attempted mutiny, but that this had been commuted to ten years imprisonment by Lord Kitchener. ${ }^{163}$

As incomplete as it was, this account understandably caused great concern and soul-searching in Australia. Hitherto little had been said publicly of the humiliation of Wilmansrust, but Beatson's accusation of cowardice brought the matter under public scrutiny. There was also concern over Australian soldiers being involved in mutiny, and consternation that Australians could be court-martialled, convicted, and fncarcerated in British gaols without the Australian government having any knowledge of the proceedings.

162 Rayne Kruger, Good-bye Dolly Gray, (London 1959), p. 436; Arthur, Life of Lord Kitchener, Vol. 2, p. 36. 
The press was quick to react. Victorian newspapers in particular endeavoured to explain the misfortunes of the 5 th V.M.R., although the exercise was usually an attempt to find a scapegoat.

The Argus published a lengthy and surprisingly knowledgeable account of the tribulations of the Victorian unit in South Africa, which must have been based on communications from men in the field, and which the paper had obviously not seen fit to publish before. The article lamented the fact that the fifth contingent of Victorians had seriously damaged the reputation of the Australian soldier in South Africa, for previously no large body of Australians had ever thrown down their arms to the enemy. It blamed the fifth also for tarnishing the image of the Australian in Cape Town by misconduct. Indiscipline was regarded as the main cause of all the contingent's trouble. This was attributed to the poorer type of recruit who had come forward towards the end of the war, and officers who were either inexperienced or, having come from the ranks, too familiar with the men. To climax these shortcomings, according to the Argus, the regiment had the misfortune to be placed under a regular officer who adopted a "hostile and offensive attitude" towards them. This manifested itself in strict disciplinary measures and disparaging remarks. Apart from his reference to the Australians as "a lot of white-livered curs", Beatson chanced to ride by when a group of them were engaged in bayonetting pigs at a farmhouse and he told the men that was all they were good for. "When the Dutchmen came along the other night you didn't fix bayonets and charge them", he was alleged to have said, "but you go for something that can't hit back". It was a few days after this incident that Private Steele suggested to his comrades that they should not again go into the field with such a man. 164

16430 September 1901 , p. 5 . 
The Age made a contribution to elucidating the troubles of the 5th V.M.R. when it published an interview with a returned officer of the contingent. He admitted that the regiment had become almost uncontrollable by its officers, but claimed that this was because of the strict discipline imposed by Genera1 Beatson who, for example, would make the entire regiment walk for a day as punishment for some men having sore-backed horses. 165

The Melbourne Punch accepted the failure of the fifth contingent, but attributed much of the blame to Imperial officers who were "no more fit to handle a body of irregulars than a mule is fit to command eagles". ${ }^{166}$ A week later it again attacked the leadership of British officers in a page of satirical cartoons. 167

The interstate press left Victoria pretty well to deal with her own shame, but an exception was the Daily Telegraph. In an editorial following the release from English prisons of "the so-called mutineers" of the 5th V.M.R., it attacked "the foul and infamous language of the Imperial officer commanding" and suggested that if the death penalties had been carried out public outcry would have led to the recall of every Australian soldier in South Africa. ${ }^{168}$

In Federal parliament, questions were asked of the prime minister after the disclosure by the Age of the mutiny, but Barton would say nothing until he received an authoritative report although he clearly showed that he had no sympathy for mutinous soldiers who had taken an oath of allegiance and become subject to the British Army Act. ${ }^{169}$ A month later, Major McKnight's

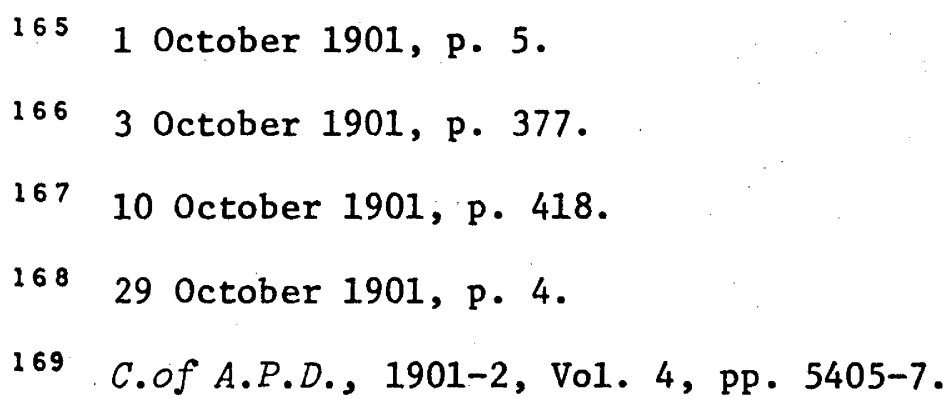


report was tabled and Barton was able to announce that a matter which "had agitated Australia very considerably" had been brought to a "happy terminatIon". The sentenced men had been released and an Imperial officer superseded in his command. 170

It was not until 7 November, however, that Barton received a reply to a telegram of 3 October to the Colonial office. It disclosed that Privates J. Steele, A. Richards and H. Parry had been tried by general court martial for inciting to mutiny and sentenced to death. The sentences were commuted to ten years'penal servitude in the case of Steele, and one year's imprisonment with hard labour in each of the other cases. When the Judge Advocate General received the proceedings of the court martial, he had declared that there were legal flaws in the convictions for the men had been tried under the wrong section of the Army Act. The immediate release of the troopers was therefore ordered. ${ }^{171}$

Parliament had demonstrated a minimum of concern over W1lmansrust and its aftermath. And when, three months later, the House of Representatives was in high dudgeon over the libels of the continental press, a member made a pertinent observation. A British officer had called Victorians "whitelivered curs", a more abusive expression than anything uttered by the continental press, yet the House had "never attempted in any shape or form to take exception to $1 t^{\prime \prime} .172$

Australian pride had undoubtedly been hurt by the events involving the 5th V.M.R., but very Iittle sympathy had been generated for the soldiers who had brought Australian fighting men into disrepute. In fact, there was

170 ibid, Vol. 5, pp. 6642-3.

171 Minute from Governor-General to Prime Minister of Australia, 7 November 1901, Commonwealth Archives MP 84/2. A claim was made that the men's release had been secured by a petition to the King by Australians in London. - Daily Telegraph, 29 October 1901, p. 4. But Barton claimed that the release was due "very largely"to the action of his government. C. of A.P.D., Vol. 5, p. 6643 . 
a tendency to disown them. More marked, though, was the desire to make Imperial officers the scapegoats for Australian errors.

One outcome of the trial and imprisonment of the three Australians was a request by Barton to Kitchener for a record of punishments by courtsmartial of members of Australian contingents. 173

Australia had a chance to regain lost prestige with the dispatch of 4,000 members of the Australian Commonwealth Horse in 1902. These went in three contingents totalling eight battalions. But the war was over before half of the A.C.H. got to South Africa. The first and second battalions did see some service in the great drives that were to end the war, but the third and fourth never heard a shot fired, and the fifth, sixth, seventh and eighth were still on the high seas when peace came on 31 May. ${ }^{174}$ There were no casualties in action, but 28 men died from illness. ${ }^{175}$

The first and second battalions landed in Natal in March and formed an Australian brigade for the great Eastern drive aimed at encircling De Wet and Louis Botha. But the mists and storms of the Drakensburg range allowed the Boers to make an easy escape, and all the Australians caught were severe colds which were treated by the A.A.M.C. unit which formed part of the brigade.

173 Minute of 30 November 1901 to Governor-General, Commonwealth Archives, MP 84/2. Returns for the entire period of the war were actually supplied but only the return for the period 1 April 1902 to 30 June 1902 is held by Commonwealth Archives. The cover sheets for the remainder of the war are extant as tantalising reminders of records that summarised the more serious disciplinary offences of Australians in the field.

174 Major-General E. Tivey Collection, A.W.M., Diary entry of 1 June 1902.

175 Conditions of Service of South African and over-Sea Contingents Employed in the South African War, 1899-1902, (H.M.S.0., London, 1904), Report from Lord Tennyson, Governor-General, to Secretary of State for the Colonies, 3 August 1903. 
The Australians were then sent to Western Transvaal to join Colonel Thornycroft's Field Force, composed of the New Zealand brigade, New South Wales Bushmen, Haslee's Scouts (an irregular corps consisting of "mostly Australians") and Thornycroft's own regular mounted infantry. The field hospital for the force was provided by the A.A.M.C. This predominantly Australian column moved forward as part of General Ian Hamilton's force of 20,000 men. The advance was known as the great Western drive and it was the last of the war. The object was to drive de $1 \mathrm{a}$. Rey and his commandos back against a chain of blockhouses. This was accomplished almost without incident, and the untried Australians for weeks had then nothing to do but sit and wait for the inevitable peace. ${ }^{176}$

The Australian Commonwealth Horse did not get an opportunity to contribute much to Australian military history, but its conduct in the field was almost beyond reproach, despite the monotony of operations and weeks of inactivity. The regiment did a lot to allay the fears of those to whom Australian discipline had so recently become suspect. A major factor in the improved state of affairs was the evident determination of Australian commanders to see that a good standard of discipline was maintained. The battle orders of the second battalion (predominantly a Victorian unit) indicated a high standard of discipline, with peremptory punishment for offenders. ${ }^{177}$ British commanders were warm in their praise for Australian discipline in this period, ${ }^{178}$ and the return of courts-martial for the period 1 April to 30 June shows only 27 cases, with the crimes mainly being disobed-

176 James Green, "The Campaigns of the Australian Commonwealth Horse", in Barton, The Story of South Africa, pp. 596-607.

177 Major-General Sir J. Bruche Collection, A.W.M.

178 ibid, Battle Orders of 30 June and $1 \mathrm{July} 1902$. 
ience, drunkenness, and insubordination. 179

The good standard of discipline enforced in South Africa was not maintained aboard at least one transport that brought troops back to Australia, however, and the slackness which followed was a contributing factor in the greatest misfortune to befall the Australian contingents at sea. S.S. Drayton Grange, out of Durban on 11 July 1902 with 2,043 troops aboard, dropped anchor in Melbourne on 7 August with five men already dead and twelve more to die within a fortnight of landing. 180 . The main killers were measles and influenza, both of which had been brought aboard in the incubation state, and a Royal Commission found that the presence of these illnesses had been aggravated by overcrowding, deficient hospital accommodation, and neglect of the discipline of mere routine which would have meant a more sanitary ship. 181

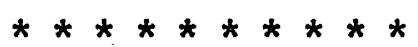

This account of Australians in South Africa has only followed the fortunes of those who served with Australian units, but thousands more fought with irregular regiments raised at the seat of war. These men drifted into the various corps in small numbers on their own initiative, and ceased to exlst as far as the Australian government and public were concerned. There was one group of Australians, however, who succeeded in maintaining their identity in an irregular unit. They were men who were recruited in Australia

179 Commonwealth Archives, MP 84/2.

180 C. of A.P.P., 1901-2, Vo1. 2, "Report of the Royal Commission, S.S. Drayton Grange", p. 17.

$181 \mathrm{ibid,p.14.} \mathrm{There} \mathrm{were} \mathrm{reports} \mathrm{of} \mathrm{expectoration} \mathrm{on} \mathrm{decks} \mathrm{and} \mathrm{walls,}$ urination in the shower baths, and lack of body cleanliness. 
specifically as Australian squadrons of a South African corps.

In December 1900, the Marquis of Tullibardine, who had served with the Royal Dragoons in Natal earlier in the war, began raising a force known as the Scottish Horse. He split it into what he called two regiments, and it was to help fill the ranks of the 2nd Scottish Horse that he obtained permission from Kitchener to wire to the Caledonian Society in Melbourne for assistance. This he did on 1 January 1901, and on 8 March, 300 Victorlans, mainly Scots by birth or by descent, joined the corps in South Africa. 182

The Marquis did not receive the fullest co-operation of Victorian authorities, however. Malcolm McEachern, president of the Caledonian Society and mayor of Melbourne, declined to assist in any way. ${ }^{183}$ Military authorities were also cool towards the idea. Eventually a retired army officer got the recruiting movement going, with the Victorian government accepting responsibility for riding, shooting and medical tests. Uniforms, equipment, and pay were matters to be cared for by the Marquis when the men reached the Cape. 184 Tullibardine found things much more difficult when he sought to recruit another 300 Australians to replace the first draft, which had been enlisted for six months only. Perturbed by the British desire to recruit in Australia for Baden Powell's South African police, the Federal goverment declared against Australia being used as a recruiting ground for non-Australian regiments. The Marquis was obliged, therefore, to send his recruiting officers

182 EZgin Commission, Vo1. 41, pp.446-7.

183 See p. 201.

184 Diary of Sergeant Robert Hodgson, 2nd Scottish Horse, A.W.M.; Age, 2 February 1901, p.10. Animosity towards the Scottish Horse squadrons was also evident among the men of the 5 th V.M.R. with whom the recruits travelled to South Africa. This resulted in frequent fights. 
aboard ships that were carrying indulgence passengers to the Cape. Lieut. Alured Kelly, formerly a private in the 2nd V.M.R., was such an officer. On one occasion he competed with another recruiter for the services of 150 indulgence passengers and enlisted 106 of them after the ship had cleared Australian waters. 185

A total of 544 men were recruited either within Australia or from among indulgence passengers. Tullibardine spoke glowingly of these troops. There were also "many Australians" among the 1,458 men recruited at ports and elsewhere in South Africa for the Scottish Horse, but he was inclined to rate them as inferior to those recruited in Australia. ${ }^{186}$ The Scottish Horse fought under conditions that were typical of the period, and Sergeant Robert Hodgson's excellent diary testifies that its Australian component served conscientiously and efficiently, although not as well, according to Tullibardine, as the men recruited from the yeomanry and volunteer militia of Scotland. 187

It is difficult even to estimate the number of Australians who served in irregular South African corps, but it must have been several thousands. Press lists of men returning from South Africa usually contained a sprinkling of names of men who had served with South African regiments. The Houlder Line alone had carried to the theatre of war by the end of 1900 over 500 Australians seeking to enlist. ${ }^{188}$ And then, of course, there were the indulgence passengers.

\footnotetext{
185 Alured Kelly, "Personal Account" pp. 36-7.

186 EZgin Commission, Vo1. 41, pp. 447, 455.

187 ibid, Vol. 41, p. 447.

188 See p. 201.
} 
The indulgence scheme was a subtle form of Imperial recruiting whereby, in return for providing a free berth on an otherwise empty troopship (with the person paying for his own messing at $1 / 6$ a day), the British authorities secured an experienced soldier at a time when the demand for horsemen for the irregular corps seemed insatiable. And the Army made sure it got its man, for military officers boarded the ship at the Cape and obliged the Australians to sign on with a corps or take the next boat home. ${ }^{189}$ The potential of indulgence passages as a recruiting method was considerable, for there was extensive unemployment in Australia at the time and the Federal government had ruled out more overt recruiting. ${ }^{190}$ But the scheme yielded only about 400 men. This poor response was partly due to the opposition of the New South Wales and Victorian governments. See, premier of New South Wales, refused to provide free transport for volunteers to the embarkation point (a condition agreed upon by the Imperial and Federal governments), and made a strong protest to the Home government over the continuance of recruiting in New South Wales. ${ }^{191}$ Peacock, the Victorian premier, refused to pay the fares of Victorians to pick up ship in Sydney for he considered the men to be going "for their own personal benefit". 192

There was also an obvious reluctance on the part of veterans to return to South Africa to join non-Australian regiments. When the Britannic sailed from Sydney in August 1901 she had about 200 men on board, and these

\footnotetext{
189 Sir Bertram Hayes, HuZZ Down (London, 1925), p. 134.

190 C. of A.P.D., 1901-2, Vol. 3, p. 3391.

191 N.S.W.P.D. 1901, Second Series, Vo1. I, pp. 452, 607. See considered that the scheme would take many young men away from the state permanently, for they were under no obligation to return when they finished their tour of duty with a South African regiment. 
were mainly ex-Bushmen who had been rallied by newspaper notices inserted by Major J.F. Thomas, a former commander of the Citizens' Bushmen. ${ }^{193}$ The Britannic was scheduled to pick up at only one other port, Albany, so it is extremely doubtful whether the captain of the vessel took to South Africa the 400-500 men he was told he would be transporting. ${ }^{194}$. When the Harlech Castle sailed from Sydney at the end of September, only 49 out of 111 New South Wales men granted indulgence passages were on board, and there were only 18 from Victoria, Queensland, and Tasmania. With only Albany to call at, the total complement of indulgence passengers could not have been more than 100.195

Many other Australians joined South African regiments in preference to returning home at the end of their year's service with Australian units. Others stayed to make a new life in South Africa. Some of these had been enticed by land offers from the Chartered Company. All colonies were aware of the situation. South Australia considered, however, that if the Imperial government made an offer to soldiers to stay in South Africa, it was hardly the duty of the colonial government to protest. ${ }^{196}$ Queensland did not seem to care at a11. ${ }^{197}$ New South Wales was the only colony to take steps to prevent her soldiers being discharged in South Africa. One action that Lyne took was to see that the troops were not paid off until they returned. ${ }^{198}$

193 Daily TeZegroph, 15 August 1901, p. 5., and 21 August 1901, p. 7. Thomas returned to South Africa himself, and achieved some note as defence counsel at the court-martial of Lieuts. H. Morant and P. Handcock.

Hayes, HuZZ Down, p. 127.

195 Daily Telegraph, 27 September 1901, p. 5. I have found no references to the embarkation of further indulgence passengers.

S.A.P.D., 1900, p. 125.

197: Q.P.D., 1900, Vo1. LXXV, p. 1506. 
Another was to ask Chamberlain to ensure that New South Wales troops were not disbanded in South Africa. ${ }^{199}$. A year later See was unable to say how many New South Wales men had stayed in South Africa but he was confident it was not a large number. ${ }^{200}$ But with the colonies generally making no effort to ensure that their troops returned, many would have found their way into the scores of irregular regiments which constantly sought recruits.

With thousands of Australians of an adventurous inclination scattered through scores of irregular units that were often poorly officered and dubiously motivated, there was a good chance that somewhere, sometime, a few of them would get into trouble. And they did.

The story of the Bushveldt Carbineers and H. Morant and P. Handcock, the two Australian lieutenants who died before a British firing squad, is the best known episode of Australian involvement in the war. Lieut. G.R. Witton, who was court-martialled along with Morant and Handcock, and who had access to the papers of Major J.F. Thomas, the defence counsel, wrote fully and authoritatively on the subject. 201 "Frank Renar" (pseudonym of Frank Fox of the Bulletin), gave another reliable account based on conversations with the executed men's commanding officer, Major R.W. Lenehan. 202 F.M. Cutlack later wrote a book which relied mainly on the work of Witton and Fox, but which raised unwarranted doubts by claiming that the records of the courtsmartial available to Witton were incomplete, and by noting the disappearance. from the War Office of the trial documents. ${ }^{203}$ All three writers accepted the

199 ibid, Vol. CVII, p. 4493.

200 ibid, 1901, Second Series, Vol. 1, p. 955.

201 Scapegoats of the Empire, (Melbourne, 1907).

202 Bushman and Buccaneer, (Sydney, 1902).

203 Breaker Morant, (Sydney, 1962). 
contention of the defence counsel that the verdicts were influenced by the representations of the German government, which demanded justice for the murder of Hesse, a German missionary. However, Morant and Handcock were acquitted of this charge, so it is hardly logical to suggest that the death sentence was carried out because of German pressures. There was also a strong inclination among the authors to suspect Kitchener of something devious in failing to act on the court's recommendations for clemency, and in ordering hasty executions. Kitchener may have wanted to see the men face the firing squad, and without delay, as a deterrent to the disregard for military law which was increasing among the irregular corps. Or he may have wanted the thing done before Australian opinion could influence the outcome. But it is difficult to see how the firing squad would cover up any irregularities on Kitchener's part.

The facts are plain enough. Early in 1901 an irregular regiment called the Bushveldt Carbineers was formed for service in the wild country of north-eastern Transvaal. At the time of the outrages it was commanded by an Australian, Major R.W. Lenehan. It had several Australians among its subalterns, and a large number of Australians in its strength of 350 men. The corps was engaged in the usual type of police work, but was left mainly to its own resources because of the remoteness of the area. It was operating with considerable effect on the roving bands of Boers in the district when a series of murders took place involving a section of the corps commanded by Morant. A wounded Boer prisoner, Visser, was shot on Morant's orders after a farcical "drumhead" côhrt-martial, and groups of three, eight, and six prisoners were also shot after capture. The German missionary was shot while on his way to Pietersburg, allegedly to report the activities of the corps. 
In a series of courts-martial which began at Pietersburg on 16 January 1902 Morant, Handcock, and Witton, and an English irregular, Lieut. Picton, were each found guilty on one or all of the charges involving Visser and the groups of three and eight Boers. Captain A. Taylor, a colonial intelligence officer, was acquitted of the charge of inciting to murder in the case of the six Boers. Handcock and Morant were acquitted of the murder of Hesse, although it is very likely that they were guilty. They were the prime suspects, and their other actions indicated that they would have had no scruples about killing the missionary. Fox hinted at their guilt in his book. 204 And in a letter to J.F. Thomas written on 21 0ctober 1929, Witton claimed that after the trial Handcock admitted to him that he followed and shot Hesse at Morant's command.205 Despite the court's recommendations of mercy (strong in respect of Handcock and Witton who were acting on orders from Morant), Handcock and Morant were shot by a squad of Cameron Highlanders at dawn on 27 February 1902. Witton's sentence of death was commuted to life imprisonment, and Picton was cashiered.

Justice does not appear to have been done, mainly because the cases were argued at two different levels of justice. The prosecution argued on the basis of King's Regulations and the Manual of Military Law, while the defence argued on the basis of the realities of Kitchener's degenerate type of warfare. Of the men court-martialled, Morant was the most deserving of punishment as the instigator of the killings, and at the trial he took full responsibility for his subordinates' actions. But in his favour it can be said that he was acting under orders from his superior, Captain Hunt, to take no prisoners, and that he was fighting an unorthodox war with little or no direction from headquarters. Morant also believed, rightly or wrongly, that Hunt met his death in particularly brutal circumstances.

204 P. 26.

205 Letter A.M. 77/8, M.L. 
Morant gained stature at his trial and execution. He would not defer to the court in any way, claiming that he fought the war in the only manner it could be fought, by "rule 303", and promising to have Kitchener brought to trial for his war crimes. And at the end of his reckless life he asked that the blindfold be taken from his eyes, and advised the firing squad to shoot straight and not mess the job up. Of such deeds are folkheroes made, but the Australian people fell too quickly on the defensive to take the opportunity.

Handcock's sentence stands out as the most unjust of the whole affair. Poor, simple, sincere Handcock, lover and tender of horses, was obsessed with the idea of duty, and never questioned any orders from his superior. Handcock did not initiate any crimes himself, but he faced the same penalty as the architect of several crimes. A letter written to his sister just before his execution suggests a man who killed but did not murder.

I have but one hour longer to exist, and although my brain has been harassed for four long months, I can't refrain from writing you a few last lines. I am going to find out the Grand Secret. I will face my God with the firm belief I am innocent of murder. I obeyed my orders and served my King as I thought best.

If I overstepped my duty I can only ask my people and country for forgiveness. . .206

One man who got off lightly was Captain Taylor. He was acquitted of inciting others to murder the six Boers, although those who carried out the act claimed it was on Taylor's orders. The testimony of other witnesses during the trials also indicated that Taylor freely subscribed to the policy of no prisoners.

In Australia the reaction to the affair was no less reprehensible that the bloody deeds themselves, or the callousness of Kitchener. It took

\footnotetext{
206 Quoted in Bathurst Western Advocate, 2 March 1964, p.3.
} 
the forms of a supine attitude on the part of the government towards Imperial authorities, an unseemly haste on the part of the press to disown the wrongdoers, and apparent public acquiescence in the executions.

As with Wilmansrust, no official notification of the matter was received in Australia. It was said that Barton heard the news from a returned trooper. 207 A month after the executions, Isaac Isaacs sought in parliament information on a matter he claimed was "agitating the minds of the people ... in an almost unprecedented degree". Barton's reply showed a strong desire to disclaim all responsibility for the men. Australia could expect no official information, he said, because the soldiers concerned "were not in any way employed by Australia, nor were they in a corps that was raised in Australia or was distinctly Australian". 208 A little later, in reply to a question whether the government would obtain the court-martial depositions, Alfred Deakin said that it was "not entitled to demand the depositions as a right", but they had been asked for "as a matter of courtesy". ${ }^{209}$ Kitchener's response to the request was a terse telegraphic report of the findings of the courts-martial which apparently satisfied the Federal government.

Press reports and editorial opinion were completely antagonistic. The Daily Telegraph published an item from the London Daily Mail which identified the executed men as Australian members of "a mixed scallywag body" and stated that "the atrocious murder and looting of surrendered Dutchmen and natives required, for the credit of England, exemplary punishment". 210 The Sydney paper's own opinion was that the public should regard the men as breakers of the laws of war. ${ }^{211}$ It also printed interviews with 207 Daizy Telegraph, 27 11/2rch 1902, p.5.

208 C. of A.P.D., 1901-2, Vol. IX, pp. 11250-1.

209 ibid, p. 11381.

21029 March 1902, p. 9.

21131 March 1902, p. 4. 
an Australian and a New Zealand member of the Bushveldt Carbineers, both of whom regarded the shootings as cold-blooded murders. ${ }^{212}$ The Brisbane Courier took comfort from the fact that Morant, "the chief offender", was an Englishman and that the regiment was not an Australian corps. ${ }^{213}$ The Advertiser expressed its confidence in Kitchener and military justice and considered the death penalty richly deserved. It was also of the opinion that although the officers involved had been spoken of as Australians "they were not so in the true sense of the word". ${ }^{214}$ The Brisbane Worker deplored the "wholesale cold-blooded butchery of defenceless men". ${ }^{215}$ The most thoughtful comment came from the Bulletin. In an article on Morant, a former contributor to its literary pages, it branded him an "accomplished good-for-naught" who had carried out the "callous or revengeful shooting of surrendered Boers in cold blood", 216 but it also saw the Australian officers as victims of their own ignorance of military law and of Kitchener's carelessness "in appointing blacksmiths, drovers and what-nots, as responsible military officers in disturbed districts". 217 In a further issue, "Frank Renar" predicted that Morant would become a bush hero along with Ned Kelly and Starlight, and suggested that his death might lead to the regeneration of jingoistic Australia. "Is it to be the fate of 'the Breaker', wearing his blood-smeared halo, to lead Australians back to the path of Right?" he asked. ${ }^{218}$ And the answer must be a partial affirmative for the episode of the Bushveldt

21210 April 1902, p. 5, and 12 April 1902, p. 9.

2138 April 1902, p. 4. Morant was an adult migrant to Australia.

2149 April 1902, p. 4.

21512 April 1902, p. 3.

2165 April 1902, Red page.

21712 April 1902, p. 7. Handcock was a blacksmith; Morant had done some droving.

21819 April 1902, Red page. 
Carbineers, more than any other single factor, fostered disenchantment with Australia's participation in the war.

The Handcock-Morant affair had a sequel some sixty years later. For more than fifty years relatives and friends of Handcock had campaigned to have the officer's name placed on the Boer War Memorial in Bathurst, his home town, but without success. Then in 1963, on receipt of a suggestion from a Western Australian veteran of the war, the Bathurst branch of the Returned Servicemen's League satisfied itself, by reading such accounts as that of Witton, that Handcock had been too harshly dealt with. The branch put its case successfully to the Bathurst City Council and Handcock's name was added to the monument. 219

It has been widely accepted over the years that the name of Handcock was removed from the original list of names on the memorial at the command of Kitchener, who opened the monument on 10 January 1910. But this is almost certainly untrue. There is no trace of a name having been removed, and Mrs. N. Rutherford, Archives Officer of the Bathurst Historical Society, states that so far as she can determine Handcock's name was never placed on the structure. Press lists of names to be included on the memorial never included that of Handcock, nor did the press at the time of Kitchener's visit make any reference to its alleged remova1. 220

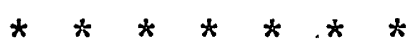

When "Frank Renar" suggested that the tragedy of Harry Morant might lead Australians to look more critically at their role in the war, he was predicting a process of national introspection that had already begun. The affair of the Bushveldt Carbineers represented the greatest shock of the war

\footnotetext{
219 Western Advocate, 2 March 1964, p. 3.

220 Letter to me, 15 July 1973.
} 
to Australian complacency over the nation's military image in South Africa, but a number of events preceding and following it also contributed to disenchantment with the cult of the warrior. Some of these events involved public displays of military indiscipline; others indicated a readiness on the part of soldiers to demand more than they perhaps deserved.

There is evidence that some Australians put up their best South African fighting performances in the streets of Cape Town. These episodes were never given any prominence in the Australian press, but an occasional newspaper reference to them, helped along no doubt by the tall tales of returning soldiers, would have made Australians aware of the disturbing behaviour of the bearers of their national honour. One of the first incidents occurred when drunken members of the second Victorian contingent became involved in a minor battle with military and civil police in Cape Town. ${ }^{221}$ Then there was the hauling down and burning of the Transvaal flag flying over the offices of the Dutch paper, Ons Lands, 222 and other damage allegedly done in the city by men of the fifth New South Wales contingent. ${ }^{223}$ But the most serious incident was the attack by Australians on the offices of the South African News, a paper which favoured the Boer cause. It seems that a number of Bushmen of the third contingent took umbrage at an article on 14 February 1901, which described the reception in Melbourne to troops aboard the Harlech Castle as "a disgusting debauch". 224 Under the heading of "Mob Rule in Cape Town", the South African News gave its version of the attack. 225 It reported that on the night of 28 March about 200 Australian troopers took over a number of the main streets and "defied and utterly disregarded the military and civil police".

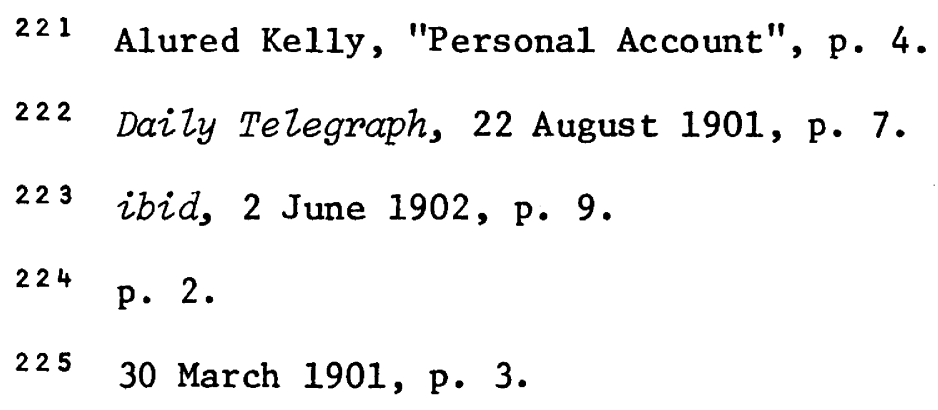


Cafe proprieters and publicans were reported as suffering at their hands; and the manager of the National Sporting Club "was severely handled" because his establishment had been the venue for a boxing match in which the decision had gone against an Australian named McKell. From there the troopers went to the offices of the newspaper and did extensive damage.

The transport Morayshire, carrying New South Wales and Queensland Bushmen mainly, was the scene of another ugly incident. Serious consequences were avoided, however, by the courage of an officer and the restraint of the majority of the men. On the voyage back from the Cape, ten troopers were given 42 days cells for refusing to holystone the decks. ${ }^{26}$ However, they were soon freed by twenty of theirfellows, although the released men immediately reported to Major W. Tunbridge. This officer called all the troops together, read the Mutiny Act and defied any man to shoot him. The men dispersed and the released men returned voluntarily to their cells. 227

Several other incidents stemmed from pay grievances. The men of the first contingent claimed that they had been promised Imperial pay of $1 / 2$ a day in addition to $4 / 6$ a day colonial pay, whereas it had been the intention of the military commandants who had met in Melbourne in September 1899 that the Imperial cavalry rate of $1 / 2$ should be made up to a total of $4 / 6$ by colonial authorities. Because of a lack of liaison between the New South Wales military commandant and his pay staff, the first contingent went to South Africa thinking they were being paid at the rate of $5 / 8$ a day. The second and third New South Wales contingents claimed the higher amount, also, on the grounds that they had been promised first contingent pay rates.

The misunderstanding was first realised in May 1900 by returning invalids, and from then until 1907 there was agitation by returned men for

226 Diary of W.N. Kelman, 2 Vols., M.L., Vol. 2, Entry of 27 May 1901.

227 Daily TeZegraph, 12 June 1901, p. 7. 
the $1 / 2$ a day which had been paid them by Imperial authorities in South Africa and which had been deducted from their total earnings by New South Wales authorities. In 1901 the New South Wales government undertook to reimburse the $1 / 2$ to the first contingent, mainly as an act of grace, and the Royal Commission of 1905-6 found in favour of the second contingent, although the commissioners contended that some men undoubtedly knew the true position before they sailed for the Cape. The Commission disallowed the claims of the third contingent. 228

In the interim, some of the men made life uncomfortable for political leaders. J. See was heckled over the pay issue when he farewelled the first battalion of the Australian Commonwealth Horse. ${ }^{29}$ And at a luncheon at Clontarf to mark the first South Africa Day (a re-union of veterans), men crowded around the official marquee and "bawled out their grievances" about back pay while the premier and other dignitaries were making speeches. ${ }^{230}$ The Daily Telegraph, which had solidly supported the war throughout, appeared to lose patience with the returned soldiers at this point. "Some of these returned men", it claimed, "have been grumbling since they first set foot on the outward bound transport, and they will probably continue until they all get into fat government billets". 231

The paper was even more caustic about soldiers when men returning aboard the Aurania gave Albany a sample of what they had earlier handed out to Cape Town. Following upon reports of damage and theft, and holding compensation claims for $\$ 900$ from Cape Town and Albany, Sir William Lyne, acting 228 Royal Commission on Pay, pp. 39, 48. A further Royal Commission sat in 1907 to rule on some claims not finalised by the first Commission.

229 Daily Telegraph, 20 February 1902, p. 5.

$230 \mathrm{ibid,} 3$ March 1902 , p. 6. The speeches were understandably subdued in their praise of the contingents. 
minister for defence, went aboard to investigate when the ship docked at Melbourne. The O.C. troops disclaimed any responsibility for looting in Cape Town and argued that "no great excesses were committed in Albany". Lyne accepted this view, but the Daily Telegraph passed contrary judgement. In a leading article titled "The Sacking of Albany" it castigated the behaviour of the troops. Their actions "realised the worst of the evils to be locally expected of militarism, that of forcible domination of citizens by swaggering soldiers". 232 The wheel had turned full circle. The "swashbuckling" militiaman of pre-war had passed through two years of adulation to become again an object of contempt. And to his destruction as hero he had made a major contribution himself.

Australian troops had little to grumble about, for they had been well treated by their governments and the public. And they had not had to suffer greatly for the benefits brought by being a member of a contingent. The casualty rate was low, and the men had only to spend twelve months in the field. In line with a recommendation of the commandants' conference, most colonies took out $£ 250$ death policies on members of the first three contingents. ${ }^{23}$ The Victorian government was one exception, preferring to stand by the dependants of deceased soldiers itself.

All Australian soldiers were eligible for Imperial pensions and compassionate allowances, but these were usually inadequate because they were geared to the poor Imperial pay rates. Needy cases, however, could get additional assistance from the Imperial Patriotic Fund, to which Australians had contributed $£ 100,000$ by 30 March $1900 .^{234}$ Colonial governments also

23228 May 1902, p. 6 .

233 The Imperial Bushmen and the Commonwealth contingents, having been raised at the request of the Home government, were regarded as the entire responsibility of Imperial authorities.

234 Argus, 30 March 1900, p. 6. For details of Imperial pensions and Patriotic Fund benefits see Argus, 28 February 1900, p. 5. 
stepped in with financial assistance and medical care where it was considered a special need existed. Pensions and compassionate allowances were not a big factor in rehabilitation, however, for few married men had been enlisted, and the dead and wounded represented small percentages of the contingents. Soldiers invalided through disease were the most numerous category and they were usually taken care of by periods of leave that covered their convalescence.

A far greater worry to Australian governments was the problem of unemployment among the thousands of returning troops. This was met partly by giving returned soldiers preference in government employment, and thus a precedent was set for subsequent wars in which Australians were involved. ${ }^{235}$ However, a suggestion that Australian colonies should follow the lead of the government of Ontario in granting 160 acres to returned soldiers was flatly rejected in the two parliaments in which the matter was raised. ${ }^{236}$

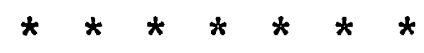

After thirty-one months of war, peace came to South Africa on 31 May 1902. The Boers went back to their devastated farms to begin the long and heart-breaking process of re-building. The British went home to inquire into the poor showing of their cumbersome military machine. The Australians went home to find their nation bent on forgetting the whole thing. Peace came as a blessing to the Australian people, not because it ended a period of national blood-shed and grief, but because it closed an episode in their history which in their enthusiasm and ignorance they had elevated into a great national trial and triumph; only to find, as their enthusiasm dulled and their

235 See S.A.P.D. 1900, p. 359; Q.P.D., 1900, Vol. LXXXV, p. 1564; V.P.D. 1900, Vol. 97, p. 293 and 1902 Vol. 100, p. 396; and N.S.W.P.D. 1901, Second Series, Vo1. 1, p. 1038.

236 S.A.P.D. 1900, p. 858; N.S.W.P.D. 1900, Vo1. CIV, p. 1432. 
ignorance lifted, that they were embroiled in a war that brought no national honour.

Understandably then, the end of the war was celebrated with restraint in Australia. Commonwealth offices closed immediately the news came through on 2 June, but the Federal government took no other initiative in celebrating the end of hostilities. According to one report, the declaration of peace had absolutely no effect in Sydney. ${ }^{237}$ On the following Sunday, thanksgiving services were held throughout the nation, but those reported in New South Wales stressed humility rather than military glory. 238

Press comment was anything but chauvinistic. The Age observed that the conflict had not been "a great or a bloody war", and gave a summary of the event in terms of Imperial triumph and tragedy. ${ }^{239}$ The Daily Telegraph gave a full-page summary of the war, also from the Imperial viewpoint, although it did mention Diamond Hill as a spot "famous in the annals of Australian military history". 240 The Advertiser said nothing about the Australian contribution, but appraised the conflict as a British affair. ${ }^{241}$ And the Brisbane Courier was full of praise for "a conquered and brave enemy". ${ }^{242}$ Much more could have been said of Australian participation and achievement, but it would have been anti-climactic after the earlier excessive praise of the Australian contingents.

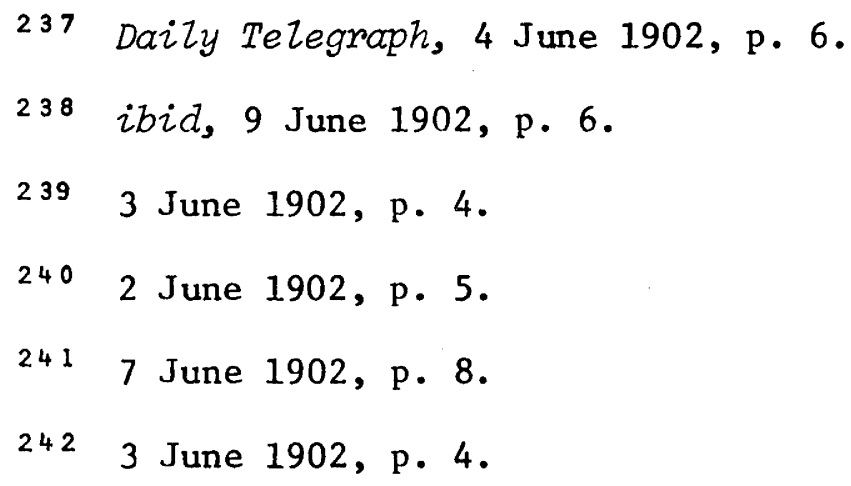




\section{CHAPTER V}

\section{Opinions of the Australian Soldier}

Letters, diaries and reports of soldiers indicate that men of the contingents were keen to win golden opinions for themselves and their country in Australia's very first war. And because they were a new and colourful force on the world's battlefields they prompted appraisal on many sides. Opinions of them were not always golden, but they were seldom unfavourable. And out of the total there emerges a well-defined image of the Australian soldier.

Contribution to the image from within Australia was 1imited, for Australians never regarded their military representatives with any degree of certainty, moving from a highly exaggerated view of their prowess early in the war to disillusionment later in the conflict.

The enemy's conception of the Australian soldier was also influenced by emotionalism, for to the Boers the overseas colonials had come voluntarily and thoughtlessly into a fight that was none of their concern. They could make allowances for the British regular who went where he was told, but the Australians, New Zealanders, and Canadians appeared to them as callous soldiers of fortune. ${ }^{1}$

A foremost, modern South African historian, Johannes Meintjes, has summarised impressions of the Australian soldier that he gained through wide research into the war. He sees him as "a man very much like a Boer, lean and tough, brave and resourceful". Australians, he considered, were "instinctive guerillas" and "on the whole... were gallant, full of guts and at times ingenious", but Meintjes feels that they lost their enthusiasm for

1 See Sydney Morning Herald, 17 February 1900, p.9, Paterson's interview with Olive Schreiner; Schikkerling, Commando Courageous, p.228; and Hales, Compaign Pictures ..., p.106. 
fighting when they came to appreciate the true situation in South Africa. He can recall no record of offensive behaviour towards civilians or natives, although their conduct was at times exuberant in the manner of all soldiers on foreign soil. 2

The record of the proceedings of the Elgin Commission is a rich source of opinion on all colonial and regular troops who fought in South Africa, and it gives a clear and consistent picture of the Australian soldier as he was seen by senior British officers. Unfortunately, Kitchener was not prepared to draw any comparisons among the troops of his command, ${ }^{3}$ and Roberts and many of the column commanders were almost as non-committal when it came to making distinctions among the colonials. Roberts said that "all the colonials did extremely well", and especially the first contingents which he equated in value with the first battalions of Imperial Yeomanry. ${ }^{4}$

General Ian Hamilton spoke of "the instinct of Colonials for country, their greater touch with nature and individual initiative", 5 and it was generally accepted by the commissioners that the colonials were more intelligent than the British soldiers. 6

The word "dashing" was commonly used of the Australians, and to exploit this quality the Marquis of Tullibardine armed his "50 best Australians" with short lances and used them with great effect against pockets of Boer resistance. ${ }^{7}$ General Rimington also cast the Australians of his command into

2 Letter to me, 21 October 1969.

3 Vo1. $40, \mathrm{p} .437$.

4 Vo1. 40, p.79. Australians would not have been flattered by the comparison, and the history of the conflict does not support Roberts' favourable opinion of the I.Y.

5 ibid, p. 80.

6 ibid, p.43.

7 Vol. 41, p.462. 
the role of shock troops when he directed them on several occasions to charge mounted with fixed bayonets. 8

All colonials were regarded as being more deficient in horsemastership or care of horses than British mounted men. ${ }^{9}$ But Tullibardine put the matter in perspective when he said of the Australians that "had they been less good horsemen they would have been better horsemasters". By this he meant that their great ability to ride led them to push their horses to the utmost. On the other hand, the Scots in Tullibardine's regiment were never inclined to gallop their horses because they were less competent riders. 10 Australians won no plaudits for their marksmanship, 11 and this was in keeping with the very ordinary standard of musketry displayed by the generality of volunteers in shooting tests prior to enlistment.

It was widely held by witnesses that colonial officers were inadequately trained, and that colonial units did better when commanded by Imperial officers. 12 However, Tullibardine spoke highly of Australian subalterns as troop leaders, 13 and Colonel Plumer was happy to accept them in that capacity, but no higher. ${ }^{14}$ As commander of a group of 20 men, a troop leader was of course perilously close to a non-commissioned officer in function. And the Australian officer's training fitted him for little more than that. Duntroon was still a decade away, and officer training for the part-time defence forces was extremely limited in time and content. A minimum of training was sufficient
8 ibid, p.584.
9 Vol. 40, p. 80.
10 Vo1. 41, p.451.
11 ibid, pp.313,451.
12 Vol. 40, pp.79-80.
13 Vo1. 41, p.451.
14 ibid, p.342. 
to turn a bushman with his ready-made military attributes into a passable soldier, but much more training was needed to produce a leader. Even Rimington in his praise of Australian officers was obliged to exclude their performances in matters of discipline and organisation. ${ }^{15}$

There was very little criticism of Australian discipline by witnesses and when it was brought up in respect of the Bushmen corps, General Knox said, without rancour, that the state of indiscipline which prevailed was just what you would expect from a group of bushmen. ${ }^{16}$

The views of the Imperial officers before the Elgin Commission are corroborated by views expressed elsewhere, ${ }^{17}$ and the Australian was accepted as a soldier of some achievement and very great potential. His dash and courage, his fearless and skilled horsemanship, his ability to endure and to find his way, and his independence and initiative, all promised the emergence of a soldier without superior if he were given good leadership, and so thoroughly trained that his tendency to indiscipline and impetuosity were eliminated.

This flattering estimate of the young nation's first soldiers is all the more commendable because it was achieved amid some difficult/y. When the Australians took the field their equipment was frequently inadequate, inappropriate or superfluous. The men of the first contingent had to be re-equipped with numerous items from Imperial stores. The second contingent fared even worse, for much of their equipment had been hurriedly manufactured

15 ibid, p. 342 .

16 ibid, p. 325.

17 See Conan Doyle, The Great Boer War, p. 188; Arthur, Life of Lord Kitchener, Vol. 1, p. 290; Watkins Yardley, With the Inniskilling Dragoons, p. 209; Bridges, Alarms and Excursions, p. 37; and The Times History, Vol. V, p. 156 . 
by unscrupulous contractors. The New South Wales and Victorian contingents were the main sufferers, ${ }^{18}$ and $R$. Sleath hurried back from his tour of the battle area to head a parliamentary select committee on the equipping and organisation of the New South Wales contingents. ${ }^{19}$ A poet had already been at work, however, and expressed the situation rather more succinctly than Sleath's committee was to do.

On the night before the battle, as I snatch a wink, perhaps,

I'11 be dreaming of my country, also of my stirrup straps.

I'11 be thinking in my slumbers of the glory that I'1I gain

If my shoddy cardboard leathers only stand the blooming rain $\ldots{ }^{20}$

The equipment situation was watched more closely in subsequent contingents, but hundreds of sore-backed horses were a legacy of earlier Inefficiency.

There were numerous other problems to contend with. The Australians' horses were given no time to acclimatise, and most fell early victims to exhaustion and an influenza-type sickness. And the re-mounts they got in place of expended horses were usually inferior types. All too frequently colonial contingents were fragmented almost to the point of losing their identity, and the relatively short time that they spent in the field meant that they left the theatre of war just when they were becoming experienced troops. They were also opposed to an elusive enemy who was reluctant to

18 See Report of Captain R.R. Thompson, A.W.M., 26 Apri1 1900 ; and V.P.D., 1900, Vo1. 93, pp. 2945, 3023.

19 N.S.W.V. \& P., 1900, Vo1. 4, "Select Committee on the Administration of the Military Department". The committee was vindictive and partisan for Sleath had an intense dislike for G.A. French. It was not supported by the Lyne government, and its findings, for what they were worth, were put aside on the grounds that Commonwealth responsibility for defence was imminent.

20 "Oriel" in the Catholic Press, 20 January 1900, p. 22. 
provide them with significant engagements, and they were subject to the dual command of their own and Imperial officers.

The small numbers of casualties suffered also made it difficult for contingents to appear as having been through the heat of battle. Australia lost 518 dead, or about three percent of the 16,000 troops sent. These were divided almost equally between deaths in action and deaths through disease. Total deaths from disease among the Imperial armies were double the deaths sustained in action. Therefore Australian deaths were considerably fewer because of greater resistance to disease, and one could also say that deaths in action were fewer than they might have been because the Australian's superior horsemanship would have got him out of many dangerous situations. (See Appendix D for casualties).

But if the casualty list was short, the list of decorations was long. (See Appendix E). Members of Australian contingents won five Victoria Crosses by rescuing de-horsed or wounded comrades from the field of battle, ${ }^{21}$ and while perhaps none of these acts was comparable with the conduct that won Victoria Cross citations in the two world wars, they indicated reckless courage, good horsemanship, and a desire to stick to one's mate in the legendary Australian tradition. The award of a C.B. to Colonel Ricardo raised serious doubts about the genuineness of decorations, however, and the commander of the Q.M.I. was the subject of a derisive attack in the Evening Observer of 2.3 April 1901. This led to a lengthy libel suit which earned Ricardo £500 damages, but which revealed his grave inadequacies as a leader. ${ }^{22}$

21 See Lionel Wigmore and Bruce Harding, They Dared Nightily, (A.W.M. Pub1ication, 1963), pp. $14 \mathrm{ff}$.

22 See Erisbane Courier, 15-19 August 1901. The Evening Observer had inquired whether C.B. in Ricardo's case meant Concealed from Boers, Caught Behind, Companion of the Boulder, etc. 
By far the greatest difficulty facing the returning veterans of the South African War was the fact that the cause for which they had fought and died had been discredited, and that they were discredited in turn. There was no way out of this problem, and it has remained as the main obstacle to a fair appraisal (or any appraisal at all) of the Australian military contribution.

But until final appraisal does come, we could do worse than accept the verdict of two men who have captured, I feel, the essence of the young Australian soldier. Rudyard Kipling recognised his practical qualities, his democratic view of life, his superior physique, his carelessness regarding a cause, and his trace of larrikinism in "The Parting of the Columns":

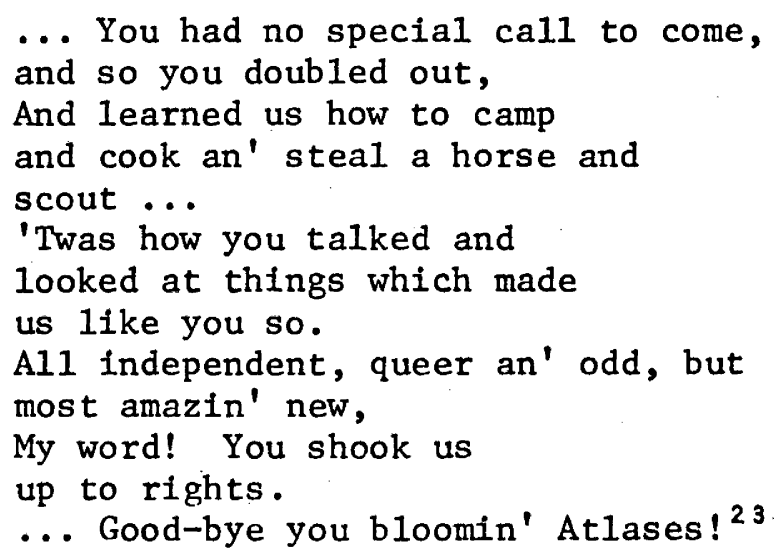

Walter Murdoch, Australian man of letters, discerned more heroic qualities in the Australian soldier, and envied him for having experienced an exhiliration denied those who stayed at home.

23 The Eive Nations, p. 175. Kipling had in mind other overseas colonials as well. 
... Be sure, for one great hour he felt

The rapture of imperious joy ...

He felt it as he stormed the hill,

And touched the topmost crest of Life.

... How shall we mourn him - we,

whose days

Creep on in sluggish, level stream ... 24

And that was something no-one could deny the volunteer. He had gone forth willingly and in good faith to experience suffering, death, and exhiliration. For that his life is not without a smatch of honour at a time when very little honour rested elsewhere in the nation.

24 Argus, 24 March 1900, p. 4, "killed in Action". 


\section{APPENDIX A}

\section{Report of the Commandants' Conference $^{1}$}

It was decided, ad interim, that the following recommendations should be made:-

1. That, in the opinion of this conference, the necessary Acts be passed without delay by each of the several colonies to enable their respective military contingents to act, either as a combined force or otherwise, for service outside Australia, and this proposal be communicated at once to the Premier, with a view to his taking the necessary action to carry out the recommendations of the conference.

2. That, in the opinion of this conference, it is desirable that information be obtained by cable as to whether the Imperial Government will defray cost of sea transport in the event of any contingents sent from Australia.

\section{RATES OF PAY AND ALLOWANCES}

The following rates of pay and allowances are recommended:-

\begin{tabular}{l|c|c|c}
\hline & per day & $\begin{array}{c}\text { Deferr'd } \\
\text { pay } \\
\text { per day }\end{array}$ & Total \\
\hline Gunners and privates & $2 / 3$ & $2 / 3$ & $4 / 6$ \\
Acting bombardiers & $2 / 9$ & $2 / 3$ & $5 /$ \\
Bombardiers & $4 / 3$ & $2 / 3$ & $6 / 6$ \\
Corporals & $4 / 9$ & $2 / 3$ & $7 /$ \\
Sergeants & $5 / 9$ & $2 / 3$ & $8 /$ \\
Company sergeant-majors & $6 / 3$ & $2 / 9$ & $9 /$ \\
Staff sergeants & $6 / 6$ & $3 / 6$ & $10 /$ \\
Warrant-officers & $7 / 6$ & $4 /$ & $11 / 6$ \\
& & Field & \\
Lieutenants & $16 /$ & $3 / 1^{\prime} n^{\prime}$. & $19 /$ \\
Captains & $20 /$ & $3 / 6$ & $23 / 6$ \\
Majors & $25 /$ & $4 / 6$ & $29 / 6$ \\
Lieutenant-colonels & $30 /$ & $6 / 6$ & $36 / 6$ \\
\hline
\end{tabular}

Adjutants, 5s per day, in addition to pay of their rank.

1 Daily T'elegraph 6 October 1899, p. 5. 


\section{COMPOSITION OF FORCE}

Resolved that - "Apart from all other considerations, the Military Conference is met to consider what united force should be sent to represent Australia, and that it should be representative of all arms, and that the details should be arranged by units.

CAVALRY: A squadron -120 to 160 of al1 ranks. ARTILLERY: A battery of Horse Artillery (4 to 6 guns); 120 of a11 ranks (4 guns).

INFANTRY: A Company - 50 of all ranks. A Battalion - Six Companies, with regimental staff.

MOUNTED RIFLES: A Company - 60 of all ranks. A Battalion - Four companies, with regimental staff.

Machine Gun Section (Mounted): Two machine guns and 17 of all ranks.

Machine Gun Section (Dismounted): Two machine guns, with one officer and 20 N.C.0.'s and men (including escort).

Bearer Company: 61 of all ranks, based on N.S.W. distribution.

\section{STRENGTH OF FORCE}

The conference submits the following numbers as suitable for a limited Australian contingent in South Africa. In making this recommendation the members have considered the desirability of furnishing a large proportion of mounted men, while yet representing all branches of the forces, and are of opinion that if a sufficiently large force representing all arms be sent it will. always remain intact, as an Australian contingent, capable of acting alone or in concert with the regular troops, but if a small force be sent there is the probability of its being scattered amongst other corps of the regular service, or being tacked on to some other colonial contingents, and 
thus have its identity destroyed.

The formation of the force proposed has received very careful consideration, and due attention has been given to the question of 'units'. Any increase or reduction in these numbers should be made by 'units' so as not to dislocate the organisation proposed.

NEW SOUTH WALES: Horse Artillery, 120; Cavalry and Mounted Rifles, 300; Infantry, 265; Departmental corps and Engineers, 60; tota1, 745.

VICTORIA: Cavalry and Mounted Rifles, 198; Infantry 345; total, 543.

QUEENSLAND: Cavalry and Mounted Rifles 275; total 275.

SOUTH AUSTRALIA: Cavalry and Mounted Infantry, 60; Infantry, 80; total, 140 .

TASMANIA: Infantry, 160 .

WEST AUSTRALIA: Infantry, 160.

The detail for general staff is put down at 30 , giving a grand total of 2,053 officers, N.C.0.'s and men.

\section{PENSIONS AND COMPASSIONATE}

ALLOWANCES

Recommended that pensions and compassionate allowances on the Imperial military scale should be paid by the colonies concerned to the wives and children of married officers and warrant officers killed on service or dying from wounds inflicted on service, on the terms and conditions prescribed by Imperial regulations; and that it is desirable that colonies concerned should in the case of all married N.C.0.'s and men of the contingents sent on service take out policies for life assurance, and for such amounts that reasonable income will be provided for widows and for 
children under 18 years of age.

\section{SELECTION OF N.C.O.'S AND MEN}

The following conditions should be kept in view in selecting N.C.0.'s and men for service:-

(a) The preference should be given to single men.

(b) Age to be from 20 to 40 years.

(c) The preference should be given to good rifle shots, and present and past efficient members of the defence forces.

(d) Pass strict medical examination.

\section{OFFICER IN COMMAND AND STAFF}

Recommended that the positions of officer commanding, second in command, and principal staff officers be filled so as to represent fairly the three larger colonies, representation on the staff or in minor commands being afforded by those colonies to the other contributing colonies.

It is also recommended that when the strength and composition of the combined force has been agreed upon by the several Governments, and the appointment of the General officer commanding and second in command is decided upon, a further meeting of those commandants who can conveniently attend be held in Sydney to select the officers of the staff. 


\section{APPENDIX B}

\section{Colonial Office Despatch of 3 October $1899^{1}$}

Secretary of State for War and Commander-in-Chief desire to express high appreciation of her Majesty's Government for the patriotic spirit exhibited by the people of Australia in offering to serve in South Africa and to furnish following information to assist organisation of forces offered into units suitable for military requirements:-

Firstly. Units should consist of about 125 men.

Secondly. May be infantry, mounted infantry, or cavalry. In view of numbers already available, infantry most, cavalry least, serviceable.

Thirdly. All should be armed with .303 rifles or carbines, which can be supplied by Imperial Government if necessary.

Fourthly. All must provide own equipment, and mounted troops their own horses.

Fifthly. Not more than one captain and three subalterns to each unit. Where more than one from single colony force may be commanded by officer not higher than Major.

In considering number which can be employed, the Secretary of State for War, guided by nature of officers, desires that each colony should be fairly represented and limits are necessary if force is to be fully utilised.

Available staff is integral portion of Imperial forces.

Would gladly accept two units each from New South. Wales and Victoria, and one from South Australia.

Conditions as follows:-

Troops to be disembarked at port of landing in South Africa, fully equipped, at cost of colonial Governments or volunteers.

1 Daily TeZegraph, 6 October 1899, p. 5. 
From date of disembarkation, Imperial Government will provide pay at Imperial rates, supplies and ammunition, and will defray expenses of transport back to the colony, and pay wound expenses and compassionate allowances at Imperial rates.

Troops to embark not later than 31st of October, proceeding direct to Capetown for orders. 
APPENDIX C

Details of Colonial Contingents ${ }^{1}$

NEW SOUTH WALES

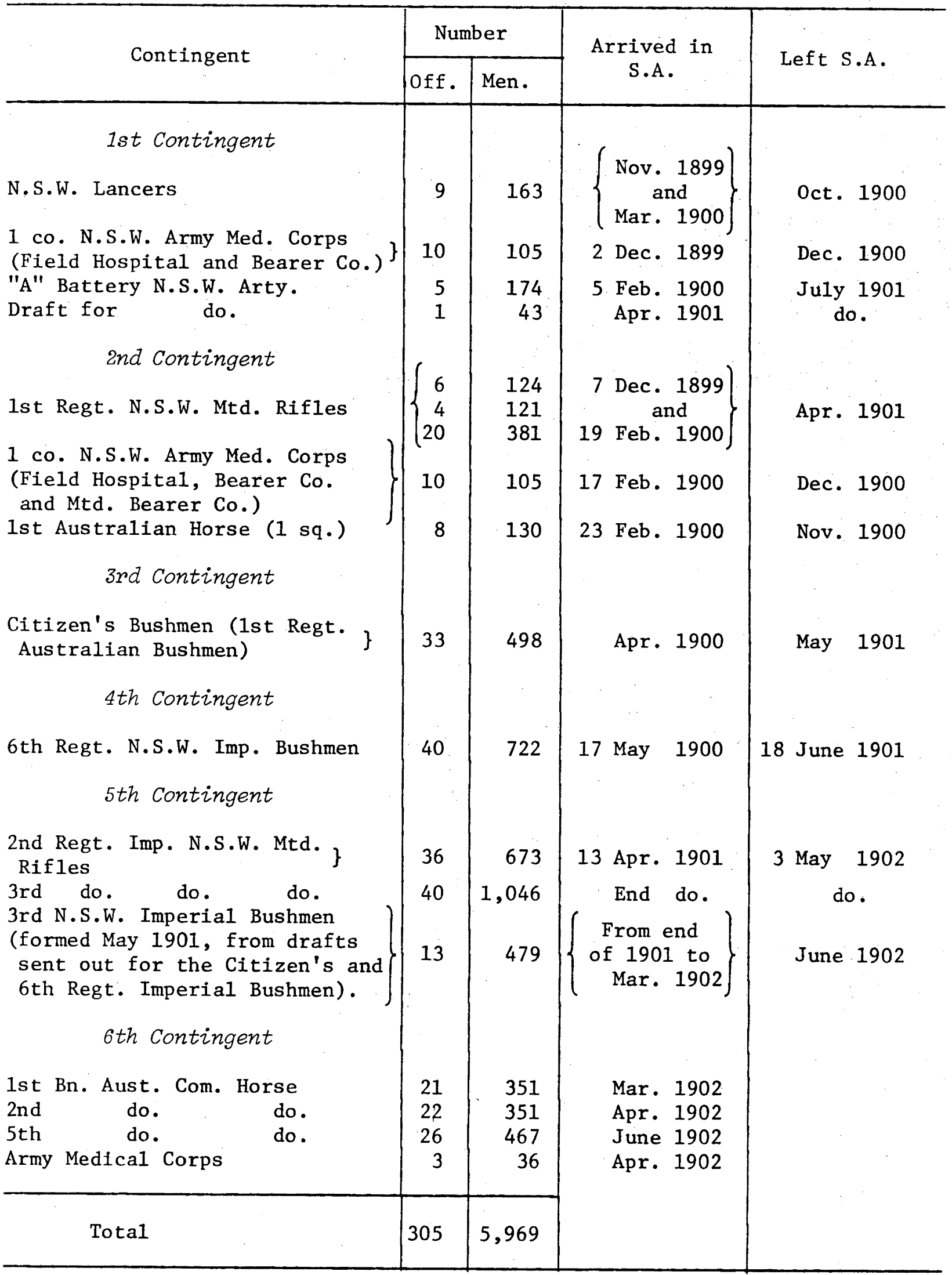

The Times History, Vol. 5, Appendix I. 
VICTORIA

\begin{tabular}{|c|c|c|c|c|}
\hline \multirow{2}{*}{ Contingent } & \multicolumn{2}{|c|}{ Number } & \multirow{2}{*}{$\begin{array}{c}\text { Arrived in } \\
\text { S.A. }\end{array}$} & \multirow{2}{*}{ Left S.A. } \\
\hline & off. & Men. & & \\
\hline 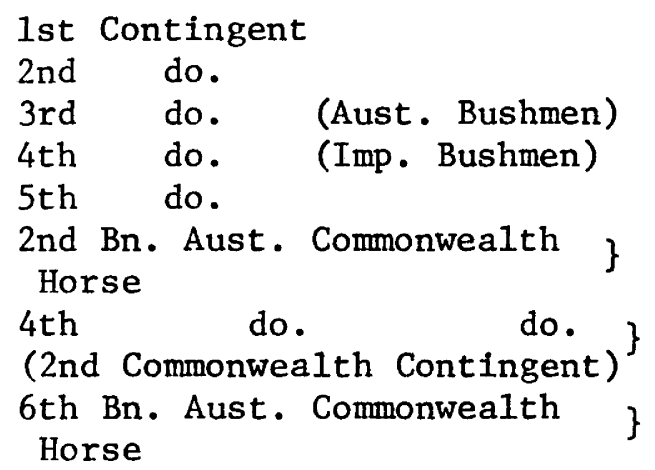 & $\begin{array}{r}12 \\
15 \\
15 \\
31 \\
146 \\
20\end{array}$ & $\begin{array}{l}240 \\
250 \\
261 \\
598 \\
971 \\
371\end{array}$ & $\begin{array}{l}\text { Nov. } 1899 \\
6 \text { Feb. } 1900 \\
12 \text { Apr. } 1900 \\
\text { May } 1900 \\
\text { Mar. } 1902 \\
\text { do. } \\
\text { Apr. } 1902 \\
\left\{\begin{array}{c}\text { beg. June } \\
1902\end{array}\right\}\end{array}$ & $\begin{array}{l}\text { Dec. } 1900 \\
\text { May } 1901 \\
\text { June } 1901 \\
26 \text { June } 1901 \\
8 \text { Apr. } 1902 \\
\text { July } 1902 \\
\text { do. } \\
\text { do. }\end{array}$ \\
\hline Total & 248 & 3,393 & & \\
\hline
\end{tabular}

QUEENSLAND

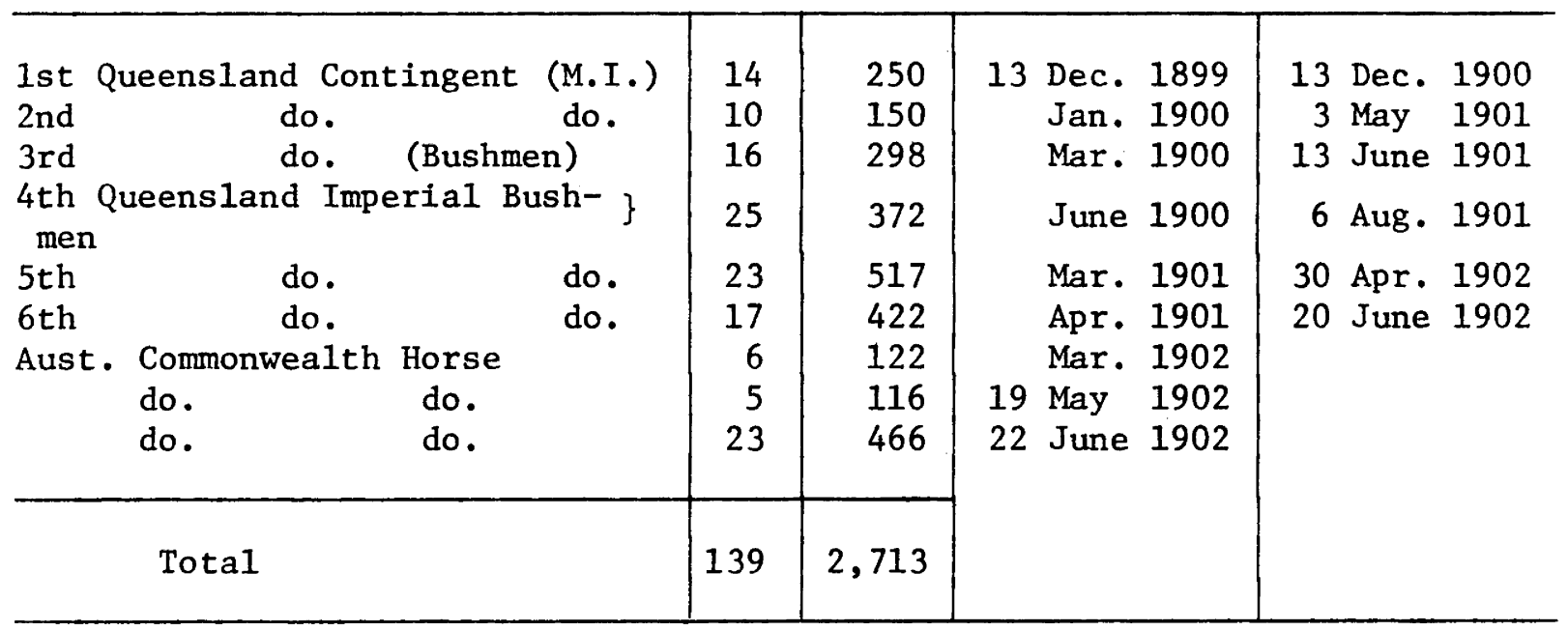


SOUTH AUSTRALIA

\begin{tabular}{|c|c|c|c|c|}
\hline \multirow{2}{*}{ Contingent } & \multicolumn{2}{|c|}{ Number } & \multirow{2}{*}{$\begin{array}{l}\text { Arrived in } \\
\text { S.A. }\end{array}$} & \multirow{2}{*}{ Left S.A. } \\
\hline & Off. & Men. & & \\
\hline 1st Contingent ("S. Aust. Infy") & 6 & 121 & 26 Nov. 1899 & 3 Nov. 1900 \\
\hline $\begin{array}{l}\text { 2nd Cont. (with lst Cont. known } \\
\text { as S.Aust. M.R.) }\end{array}$ & 8 & 113 & $25 \mathrm{Feb} \cdot 1900$ & 26 Mar. 1901 \\
\hline $\begin{array}{l}\text { 3rd S.A. Bushmen Cont. (1st } \\
\text { Bushmen's Corps) }\end{array}$ & 6 & 94 & 11 Apr. 1900 & Apr. 1901 \\
\hline 4th S.Aust. Imp. B. Corps & 12 & 218 & 29 May 1900 & 7 July 1901 \\
\hline $\begin{array}{lll}5 \text { th } & \text { do. } & \text { do. } \\
6 \text { th } & \text { do. } & \text { do. }\end{array}$ & $\begin{array}{l}22 \\
11\end{array}$ & $\begin{array}{l}303 \\
127\end{array}$ & $\begin{array}{ll}25 & \text { Mar. } 1901 \\
29 & \text { Apr. } 1901\end{array}$ & $\begin{array}{c}\text { Apr. } 1902 \\
\text { do. }\end{array}$ \\
\hline $\begin{array}{l}\text { Ist Aust. Com. Horse, D Co. } \\
\text { 2nd Bn. }\end{array}$ & 5 & 116 & 17 Mar. 1902 & 5 July 1902 \\
\hline $\begin{array}{l}\text { 2nd Aust. Com. Horse, C Co. } \\
\text { 4th Bn. }\end{array}$ & 5 & 116 & 29 May 1902 & \\
\hline 3rd Aust. Com. Horse, 8 th Bn. & 10 & 231 & 21 June 1902 & \\
\hline Total & 85 & 1,439 & & \\
\hline
\end{tabular}

WESTERN AUSTRALIA

\begin{tabular}{|c|c|c|c|c|}
\hline 1st Contingent & 5 & 125 & Nov. 1899 & Nov. 1900 \\
\hline $\begin{array}{l}\text { 2nd do. ( called 3rd }\} \\
\text { Bushmen) }\end{array}$ & 6 & 97 & Feb. 1900 & Mar. 1901 \\
\hline $\begin{array}{l}\text { 3rd do. (W.A. M.I. } \\
\text { Bushmen's Cont.) }\end{array}$ & 7 & 109 & Apr. 1900 & Apr. 1901 \\
\hline 4th do. (Bushmen) & 7 & 119 & June 1900 & July 1901 \\
\hline $\begin{array}{ll}5 \text { th } & \text { do. } \\
6 \text { th } & \text { do. }\end{array}$ & $\begin{array}{l}13 \\
13\end{array}$ & $\begin{array}{l}207 \\
214\end{array}$ & $\begin{array}{l}\text { Mar. } 1901 \\
\text { Apr. } 1901\end{array}$ & $\begin{array}{c}\text { Apr. } 1902 \\
\text { do. }\end{array}$ \\
\hline $\begin{array}{l}\text { E sq. 2nd Bn. Aust. Com. Horse } \\
\text { Aust. Army Med. Corps (W. Aust. } \\
\text { Section) }\end{array}$ & $\cdots$ & $\begin{array}{r}58 \\
7\end{array}$ & $\begin{array}{c}\text { Mar. } 1902 \\
\text { do. }\end{array}$ & $\begin{array}{c}5 \text { July } 1902 \\
\text { do. }\end{array}$ \\
\hline D sq. 4th Bn. Aust. Com. Horse & 5 & 115 & Apr. 1902 & 11 Ju1y 1902 \\
\hline D sq. 8th Bn. Aust. Com. Horse & 4 & 116 & June 1902 & 27 June 1902 \\
\hline Total & 62 & 1,167 & & \\
\hline
\end{tabular}


TASMANIA

\begin{tabular}{|c|c|c|c|c|c|}
\hline \multirow{2}{*}{ Contingent } & \multicolumn{2}{|c|}{ Number } & \multirow{2}{*}{\multicolumn{2}{|c|}{$\begin{array}{l}\text { Arrived in } \\
\text { S.A. }\end{array}$}} & \multirow{2}{*}{ Left S.A. } \\
\hline & off. & Men. & & & \\
\hline $\begin{array}{l}\text { 1st Contingent } \\
\text { Draft for above }\end{array}$ & $\begin{array}{l}4 \\
1\end{array}$ & $\begin{array}{l}72 \\
47\end{array}$ & $\begin{array}{ll} & \text { Nov. } \\
18 \text { Feb. }\end{array}$ & $\begin{array}{l}1899 \\
1900\end{array}$ & 3 Nov. 1900 \\
\hline $\begin{array}{l}\text { 2nd Contingent (Tasmanian } \\
\text { Bushmen's Cont.) }\end{array}$ & 3 & 49 & 31 Mar. & 1900 & 19 May 1901 \\
\hline $\begin{array}{l}\text { 3rd Contingent (1st Tasmanian } \\
\text { Imperial Bushmen) }\end{array}$ & 5 & 119 & May & 1900 & 7 July 1901 \\
\hline $\begin{array}{l}\text { 4th Contingent (2nd Tasmanian } \\
\text { Imperial Bushmen) }\end{array}$ & 11 & 243 & 24 Apr & 1901 & $\begin{array}{l}22 \text { May } 1902 \\
(8 \text { and } 159)\end{array}$ \\
\hline E sq. Ist Aust. Com. Horse & 3 & 60 & 14 Mar. & 1902 & 11 July 1902 \\
\hline E sq. 3rd Aust. Com. Horse & 5 & 116 & 10 May & 1902 & do. \\
\hline C sq. 8th Aust. Com. Horse & 5 & 116 & 21 May & 1902 & \\
\hline Total & 37 & 821 & & & \\
\hline
\end{tabular}


CANADA

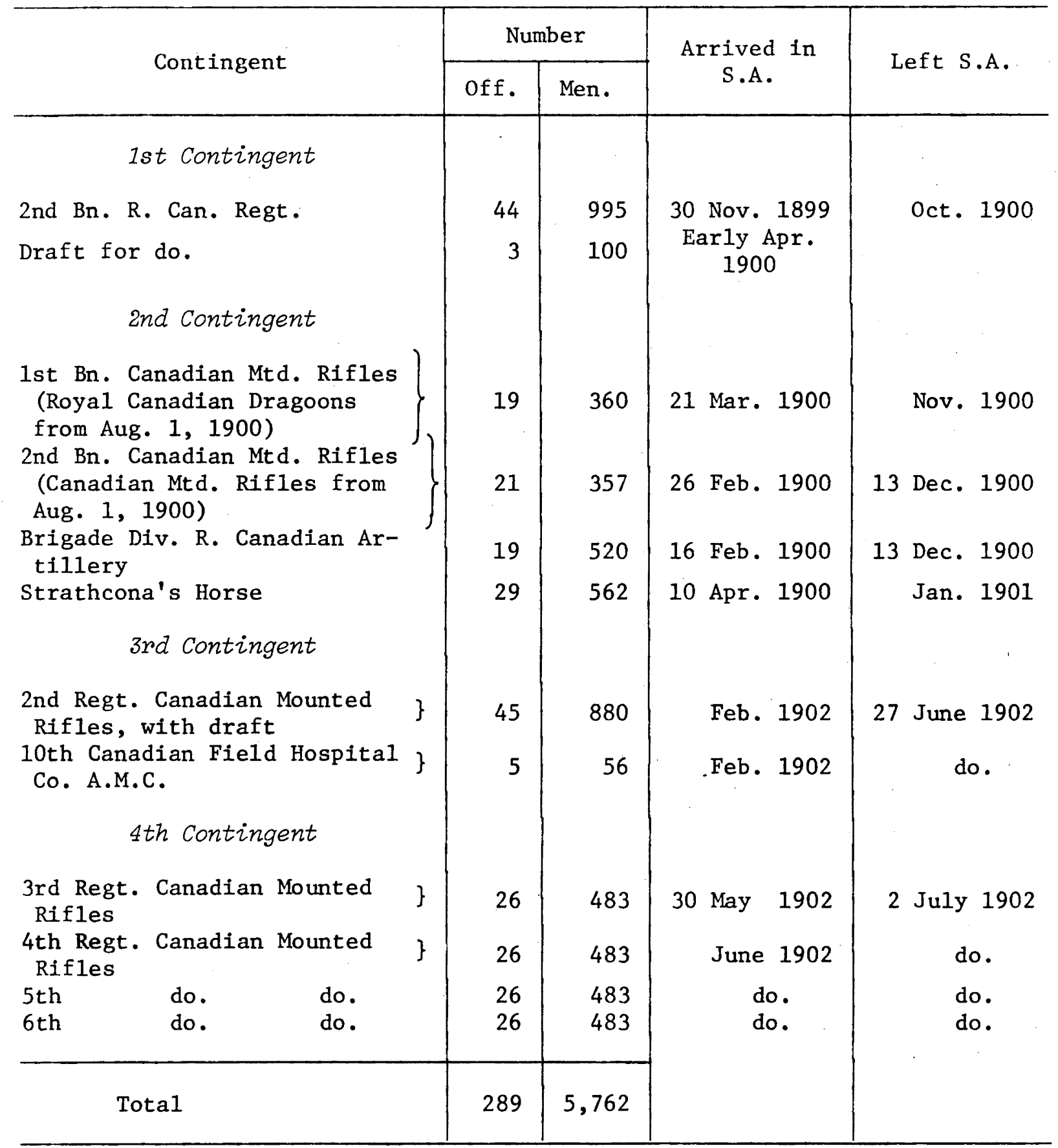

N.B. - Canada contributed 30 officers and 1,208 N.C.0.'s and men to the South African Constabulary - not included in the above figures. 
NEW ZEALAND

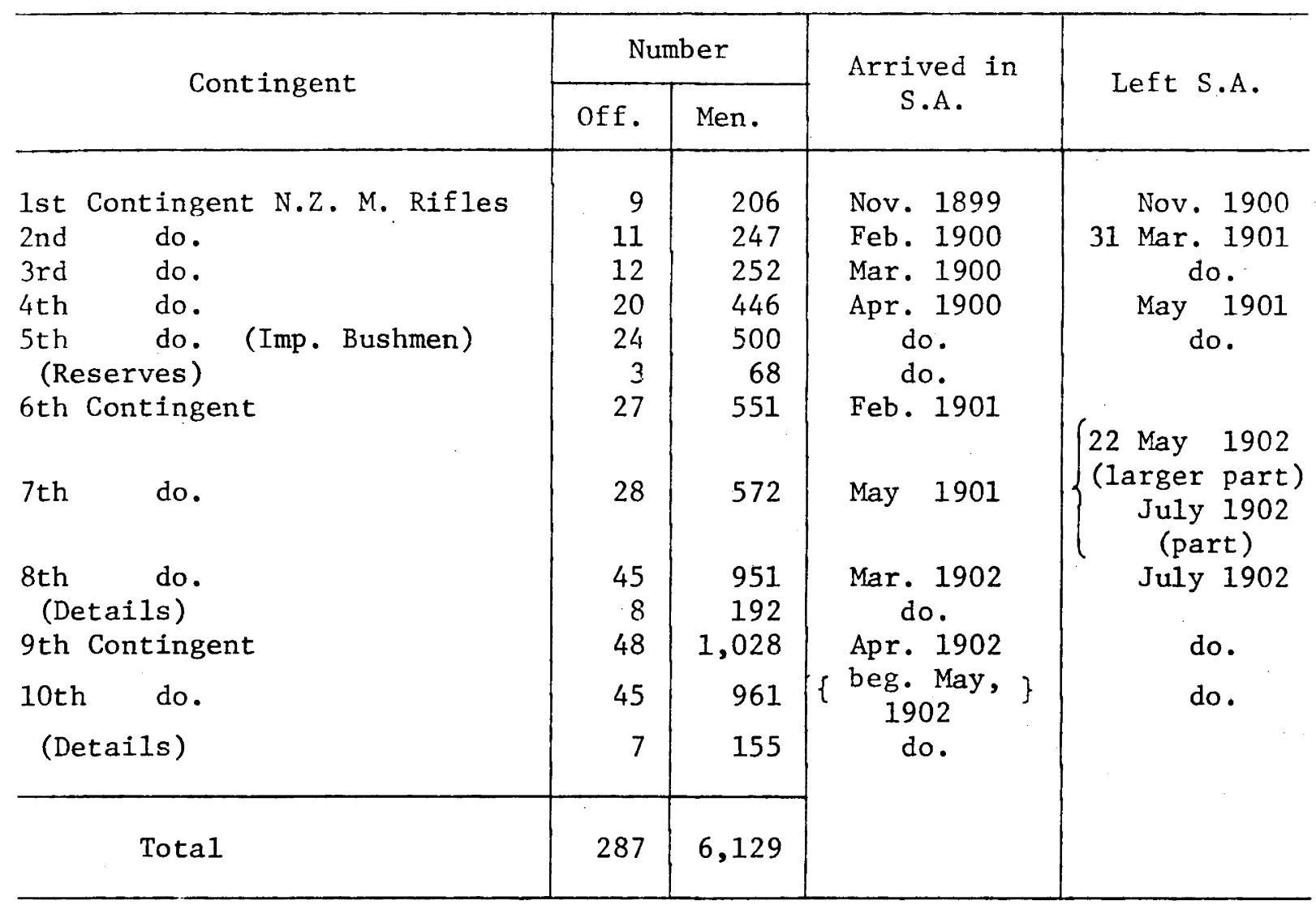

INDIA AND CEYLON

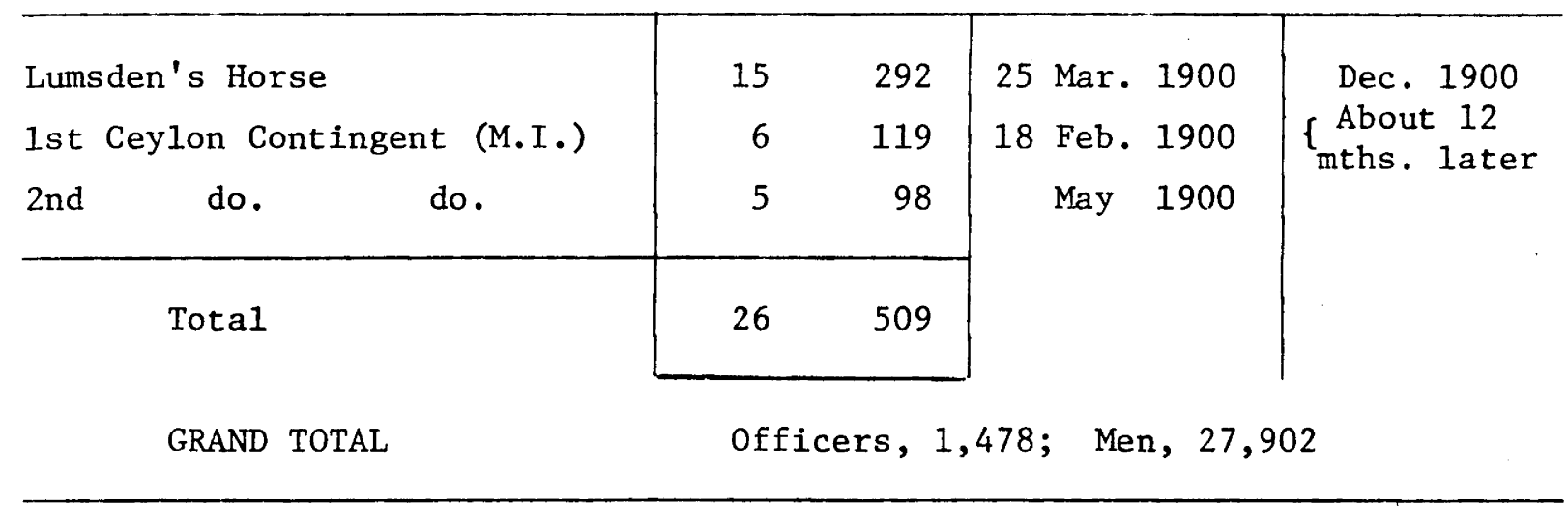




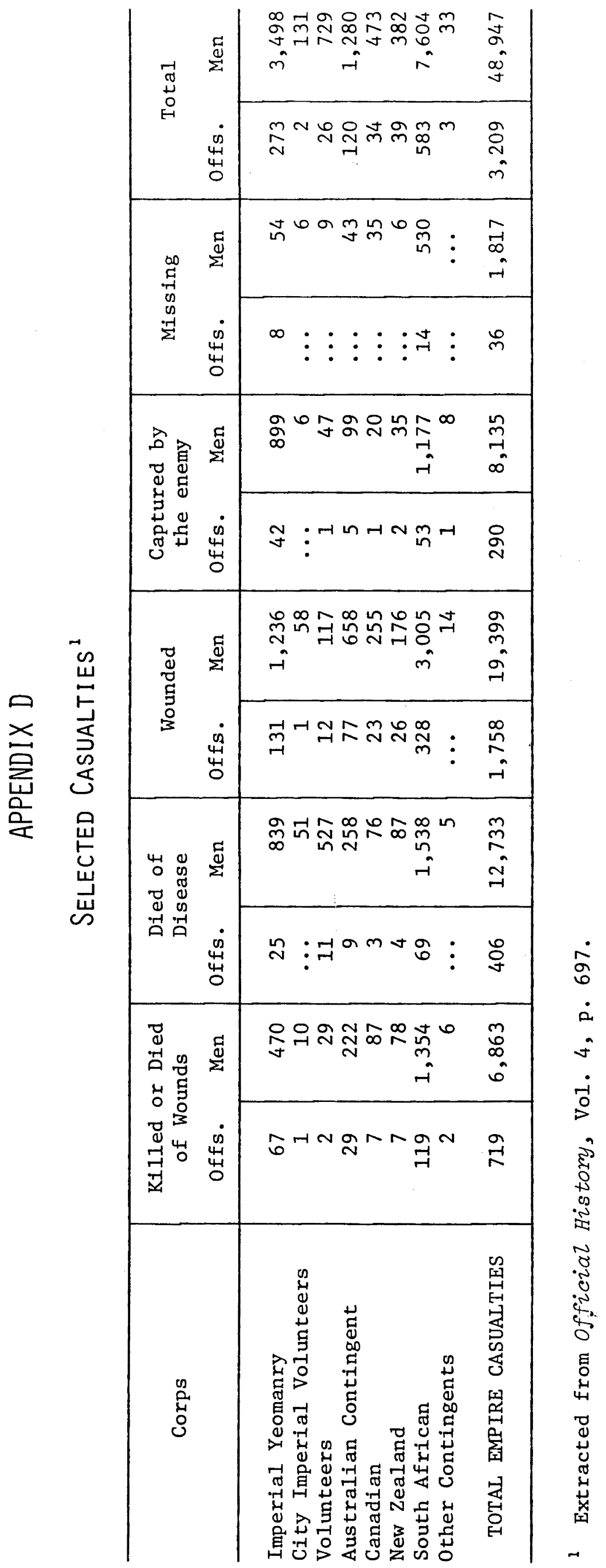




\section{APPENDIX E}

\section{Australian DeCORATIONS ${ }^{1}$}

\begin{tabular}{l|c|c|c|c|c|c|c|c}
\hline & V.C. & C.B. & C.M.G. & D.S.O. & D.C.M. & M.I.D. & R.R.C. & Tota1 \\
\hline N.S.W. & 1 & 8 & 1 & 24 & 16 & 90 & 1 & 141 \\
Vic. & 1 & 3 & 2 & 12 & 13 & 75 & 1 & 107 \\
Q1d. & & 5 & 3 & 8 & 13 & 60 & & 89 \\
S.A. & & 3 & & 8 & 10 & 42 & 1 & 64 \\
W.A. & 1 & 1 & & 6 & 8 & 59 & & 75 \\
Tas. & 2 & 3 & & 4 & 5 & 34 & & 48 \\
TOTAL & 5 & 23 & 6 & 62 & 65 & 366 & 3 & 524 \\
\hline
\end{tabular}

This table excludes awards to men not serving with Australian units, e.g. Sgt. J. Rogers, V.C., of the South African Constabulary.

1 W.M. Chamberlain, To Shoot and Ride, Military Historical Society of Australia Publication, 1967), p. 70. 


\section{MANUSCRIPT SOURCES}

\section{Australian National Library}

Cox Papers, MS 37.

Hutton Papers, MS 1215.

Murray Papers, Series 2, MS 2245.

Ricardo Papers, MS 1928.

\section{Australian War Memorial Library}

Bruche, Major-General Sir J. Collected Papers.

Harnett, Trooper H.L. Letters and Diary.

Hodgson, Sgt. Robert. Diary.

Kelly, Alured. "Personal Account of Service with 2nd Victorian Contingent". Kelman, W.N. Diary.

Price, Lieut.-Colonel Tom. "Services of Victorian Troops in the Boer Campaign".

Steel, Trooper W.A. Diary.

Techow, Private Otto. Diary.

Tivey, Major-General E. Collected Papers.

Reports of New South Wales officers in South Africa to the Military Commandant, File 565/5/2.

\section{Mitche11 Library}

Antill, J.M. "Record of N.S.W. Mounted Rifles". A paper in the Macarthur Collection.

Barham, W.H. Diary, MS B1680.

Holme, Charles B. Letters, Microfilm.

Nisbet, Major W.B. Extracts from Diary, MS B1323.

Weir, F.V. Diaries and Letters, MS 1024/1.

Uncatalogued MSS, Sets 30 and 267.

Other

Copy of the Diary of Q.M.S. Rauchle, "A" Battery. Held by Captain I. Macinnis, R.A.A., Victoria Barracks, Sydney.

Collection of Papers on the South African War. Held by Captain I. Macinnis. 


\title{
Parliamentary and Other Official Papers
}

Parliamentary Debates for all Australian Colonies, July 1899 - June 1902.

Parliamentary Debates for the Commonwealth, 1901-2.

Report and Proceedings of the Select Committee on the Administration of the Military Department, N.S.W.V. \& P., 1900, Vo1. 4.

Report of the Royal Commission, S.S. Drayton Grange, C.P.P., 1901-2, Vo1. 2.

Report of the Royal Commission of Inquiry into Claims of Members of New South Wales Contingents in South Africa together with Copy of Commission, Minutes of Proceedings, Evidence and Appendix. Sydney, 1906.

"Report of His Majesty's Commissioners Appointed to Inquire into the Military Preparations and Other Matters Connected with the War in South Africa", being Vol "s.40-42 of Reports from Commissioners, Inspectors and Others. London, 1903.

Reports of Colonial Military Commandants, collected by colony in single volumes covering several years. A.W.M.

Correspondence of Colonial Governors with Colonial Office, 1899. Microfilm, A.N.L.

\author{
New South Wales, C.0. 201/625 \\ Victoria, C.0. 390/148 \\ Queensland, C.0. 234/67-70.
}

A collection of reports, memorials, etc., of the New South Wales Government concerning the South African War, with a binder's title of "N.S.W. Soudan and South Africa Contingents 1885-1907" but referred to throughout this thesis as "New South Wales Government Papers, A.W.M.".

Letters to Lord Beauchamp, 1899-1901. A3012, M.L.

New South Wales Governor - Miscellaneous Papers, 1899-1901. 2/8094, State Archives.

Miscellaneous Papers on the South African War. MP 84/2, Commonwealth Archives, Canberra.

Conditions of Service of South African and Over-Sea Contingents Employed in the South African War, 1899-1902. H.M.S.0., London, 1904.

South Australian Statistical Register, 1899. Adelaide, 1899. 


\section{NEWSPAPERS}

Advertiser, Adelaide, January 1900 - June 1902.

Age, Melbourne, May 1899 - June 1902.

Argus, Melbourne, May 1899 - June 1902.

Barpier Miner, Broken Hill, October - December 1899.

Brisbane Courier, July 1899 - June 1902.

Bulletin, Sydney, July 1899 - June 1902.

Catholic Press, Sydney, July 1899 - September 1900.

Daily Telegraph, Sydney, July 1899 - September 1902.

Grenfell Record, October 1899 - June 1900.

Launceston Examiner, October - December 1899.

Manaro Mercury, (sic), Cooma, July - December 1899.

Punch, Melbourne, 3 and 10 October 1901.

Singleton Argus, October - December 1899.

Sydney Moming Herald, June 1899 - March 1901.

West Australian, Perth, October - December 1899.

Western Advocate, Bathurst, January - March 1964.

Western Argus, Kalgoorlie, September - December 1899.

Worker, Brisbane, July 1899 - June 1902.

Press Cuttings, 1898 - 1919, Cox Papers, M.L.

Press Cuttings, 1893 - 1904, Hutton Papers, A.N.L.

Photostat copies of relevant sections of the South African News, 14 February and 30 March 1901. 


\section{Books and Articles in Periodicals}

Abbott, J.H.M., PZain and VeZdt, London, 1903.

Abbott, J.H.M., Tommy Cornstalk, London, 1902.

Amery, L.S. (ed.)., The Times History of the War in South Africa, 6 Vols. and Index, London, 1900-09.

Arthur, Sir George, Life of Lord Kitchener, 3 Vols., London, 1920.

Atkinson, L.D., "Australian Defence Policy, A Study of Empire and Nation (1897-1910)", Ph.D. thesis, A.N.U., 1964.

Barton, G.B. and others, The Story of South Africa, Australasian Edition, Sydney, n.d.

Birch, James H., Jnr. History of the War in South Africa, With an appendix on the Australasian Colonies in the War. Toronto, n.d.

Blackmore, E.G., The Story of the South Australian Bushmen's Corps, 1900, Adelaide, 1900.

Bridges, Sir Tom, AZarms and Excursions, London, 1938.

Bufton, John, Tasmanians in the Transvaal War, Hobart, 1905.

CasselZ's History of the Boer War, 2 Vols., London, 1903.

Chamberlain, W.M., To Shoot and Ride, Military Historical Society of Australia Publication, 1967.

Churchi11, W.S., My Early Life, London, 1930.

Coghlan, T.A., The Wealth and Progress of New South Wales, 1898-9, Sydney, 1900 .

Conan Doyle, Arthur, The Great Boer War, London, 1903.

Conan Doyle, Arthur, The War in South Africa, Its Cause and Conduct, London, 1902.

Creswicke, Louis, South Africa and the Transvaal War, 6 Vols., Edinburgh, 1900-1.

Cutlack, F.M., Breaker Morant, Sydney, 1962.

Davitt, Michael, The Boer Fight for Freedom, New York and London, 1902.

Dawson, W.H., War Songs, 1899-1900, Hobart, 1901.

De Wet, C.R., Three Years War, London, 1902. 
Evatt, H.V., Australian Labour Leader, Sydney, 1940.

Forrest, Sir George, The Life of Lord Roberts, K.G., V.C., London, 1914.

Gardner, Brian, Mafeking, A Victorian Legend, London, 1966.

Gardner, Brian, AZZenby, London, 1965.

Gibson, G.F., The Story of the Imperial Light Horse in the South African War, $\mathrm{n} \cdot \mathrm{p} \cdot \mathrm{p} \cdot, 1937$.

Gilbert, Sharrad A., Rhodesia - and After, London, 1901.

Goldmann, C.S., With General French and the Cavalry in South Africa, London, 1902 .

Gordon, Donald C., The Dominion Partnership in Imperial Defense, 1870-1914, Baltimore, 1965.

Green, James, The Story of the Bushmen, Sydney, 1903.

Hales, A.G., Campaign Pictures of the War in South Africa (1899-1902): Letters from the Front, London, 1900.

Hall, D.O.W., The New Zealanders in South Africa, 1899-1902, Wellington, 1949.

Hancock, W.K. and Van Der Poel, Jean (eds.), Selections from the Smuts Popers, Vo1. 1, Cambridge, 1966.

Harding, William, War in South Africa, With a History of the Australian Contingents in the South African War, by Donald Macdonald, Melbourne, n.d.

Harlfington, Sir Charles, PZumer of Messines, London, 1935.

Haydon, A.P., "South Australia's First War", in Historical Studies of Australia and New Zealand, Vol. 11, No. 42.

Hayes, Sir Bertram, HuZl Down, London, 1925.

Headlam, Cecil (ed.), The Milner Papers, 2 Vols, London, 1931-3.

Hobson, J.A., The War in South Africa, London, 1900.

Hughes, Colin A. and Graham, B.D., A Handbook of Australian Government and Politics, 1890-1964, Canberra, 1968.

Hutchinson, Frank and Myers, Francis, The Australian Contingent, Sydney, 1885.

Jackson, Murray Cosby, A Soldier's Diary, South Africa 1899-1901, London, 1913.

James, David, Lord Roberts, London, 1954. 
Kipling, Rudyard, The Five Nations, London, 1903.

Kruger, Rayne, (rookl-kyge lollyy (iray, London, 1959.

Lewis, Major R.c., On the Veldt, Hobart, 1902.

McLean, Major A.A., Letters, South Africa 1899-1902, Sydney, 1931.

Magnus, Philip, Kitchener, Portrait of an Imperialist, London, 1958.

Maurice, Sir Frederick (ed.), History of the War in South Africa, 1899-1902, 4 Vols. with companion Vols. of maps, London, 1906-10.

Meintjes, Johannes, De La Rey, Lion of the West, Johannesburg, 1966.

Miller, Arthur, Collected Plays, London, 1965.

Murray, P.L. (ed.), Official Records of the Australian Military Contingents to the War in South Africa, Melbourne, 1911.

"Oriel" (John Sandes), Balzads of Battle, Melbourne, n.d.

Paterson, A.B., Happy Dispatches, Sydney, 1935.

Paterson, A.B., Rio Grande and Other Verses, Sydney, 1933.

Pearse, Henry H.S., The History of Lumsden's Horse, London, 1903.

Penny, Barbara, "Australia's Reactions to the Boer War - a Study in Colonial Imperialism", in Joumal of British Studies, Vol. VII, No. 1.

Penny, Barbara, "The Australian Debate on the Boer War", in Historical Studies, Vo1. 14, No. 56.

Pilcher, Colonel T.D., Some Lessons from the Boer War, London, 1903.

Reay, W.T., Australians in War: With the Australian Regiment from Melbourne to BZoemfontein, Melbourne, 1900.

"Renar, Frank" (Frank Fox), Bushman and Buccaneer, Sydney, 1902.

Satchwe11, A.E., On Active Service, Camperdown, n.d.

Schikkerling, R.H., Commando Courageous, Johannesburg, 1964.

Scot Skirving, R., "Our Army in South Africa", National Library Pamphlets, Vol. 185, No. 3589.

Semmler, Clement, The Banjo of the Bush, Melbourne, 1966.

Simpson, Lieut.-Colonel R.J.S., The Medical History of the War in South Africa, London, 1911.

Spurgin, Kar1 B., On Active Service with the Northumberland and Durhom Yeomanry, London, n.d.

Stacey, Colonel C.P., "Canada and the South African War", in Canadian Army Journal, Vol. 4, Nos. 2-4. 
Stirling, John, The Colonials in South Africa 1899-1902, Edinburgh, 1907. Tremearne, A.J.N., Some Austral-African Notes and Anecdotes, London, 1913. Twistleton, Corporal F., With the New Zealanders at the Front, Skipton, n.d. Vernon, P.V., The Royal New South Wales Lancers, 1885-1960, Sydney, 1961. Watkins Yardley, J., With the Inniskizling Dragoons, London, 1904. Wigmore, Lionel in collaboration with Harding, Bruce, They Dared Mightily, A.W.M. Publication, 1963.

Wilkinson, Frank, Australian Cavalmy: The New South Wales Lancers and the First Australian Horse, Sydney, 1901.

Wilkinson, Frank, Australia at the Front: A Colonial View of the Boer War, London, 1901.

Wilson, H.W., With the Flag to Pretoria, 2 Vols., London, 1900.

Witton, George, R., Scapegoats of Empire, Melbourne, 1907. 


\section{SOUTH AFRICAN WAR THEATRE OF OPERATIONS}

MINOR PLACES SHOWN ARE THOSE WHERE

AUSTRALIANS WERE MOST INVOLVED.

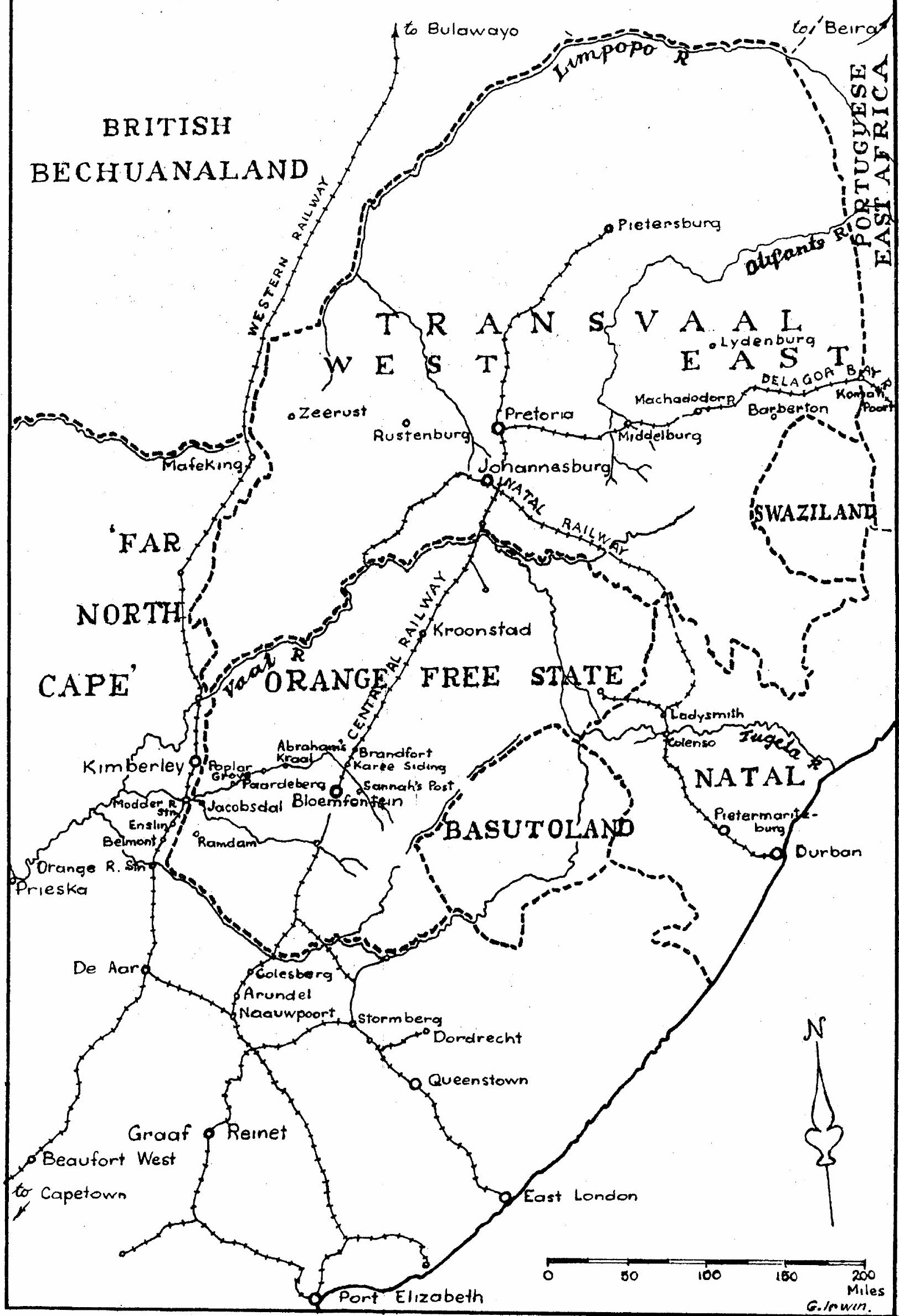

